\author{
UNIVERSIDADE DE SÃO PAULO \\ FACULDADE DE Filosofia, LETRAS E CiÊNCIAS Humanas \\ DEPARTAMENTO DE TEORIA LITERÁRIA E LITERATURA COMPARADA \\ PROGRAMA DE PÓS-GRADUAÇÃo EM TEORIA LITERÁRIA E \\ LITERATURA COMPARADA
}

ANA PAULA DOS SANTOS MARTINS

\title{
ENTRE ESPELHOS E MÁSCARAS: O JOGO DA REPRESENTAÇÃO EM AS HORAS NUAS
}




\author{
UNIVERSIDADE DE SÃO PAULO \\ FACULDAdE DE Filosofia, LETRAS E CIÊNCIAS HuMANAS \\ DEPARTAMENTO DE TEORIA LITERÁRIA E LITERATURA COMPARADA \\ Programa de PÓS-GRAdUAÇÃo EM TEORIA LITERÁRIA E \\ LITERATURA COMPARADA
}

\title{
ENTRE ESPELHOS E MÁSCARAS: \\ O JOGO DA REPRESENTAÇÃO EM AS HORAS NUAS
}

Ana Paula dos Santos Martins

\begin{abstract}
Tese apresentada ao Programa de Pós-Graduação em Teoria Literária e Literatura Comparada do Departamento de Teoria Literária e Literatura Comparada da Faculdade de Filosofia, Letras e Ciências Humanas da Universidade de São Paulo, para a obtenção do título de Doutor em Letras.
\end{abstract}

Orientadora: Profa. Dra. SANDRA G. T. VASCONCElos 
Llo Sosé Wicente, com amor.

\& a todtas as mulheres que buscam se dizer. 


\section{AGRADECIMENTOS}

Agradecimento é o ato ou o efeito de agradecer; trata-se de reconhecer e declarar de que se está grato por algo dado ou feito por outrem, segundo a definição corrente nos dicionários. Por essas razões, mesmo temendo esquecer alguém importante para declarar minha gratidão, arrisco-me a citar aqueles que, de modo especial, estiveram, cada um ao seu modo, presentes durante o desenvolvimento desta tese.

Agradeço a Deus, pela força e sustento nessa caminhada.

Às raízes dessa trajetória, minhas avós (in memorian) Lúcia e Luzia, analfabetas, que desconheceram os mistérios e os prazeres da leitura e jamais puderam se expressar pelo exercício da escrita, mas que reconheceram na educação a possibilidade de futuro para as mulheres das gerações que as sucederam, nas quais me incluo.

Ao meu esposo, José Vicente. Obrigada, querido, pelo apoio incondicional, pelo carinho, afeto, paciência, compreensão que você me dedicou em TODAS as etapas de elaboração desta tese. Assim como ocorreu no mestrado, peço desculpas mais uma vez por ter dedicado menos atenção a você que a algumas mulheres e homens de Lygia Fagundes Telles... Palavras são apenas palavras diante da grandiosidade de seus gestos e atitudes, mas são minhas ferramentas para agradecer tudo o que você representa em minha vida.

Ao meu pai, Irimeu, minha irmã, Andréia e, em especial, minha mãe Adenilde. Ah, mãe! Como é bom poder ter mãe para chamar quando as adversidades se agigantam! Obrigada por tudo que a senhora fez e faz por mim. Sem seu apoio, eu não teria chegado até aqui.

À amiga Izabela Struziato. Amiga de verdade, como você, é assim: ri, chora, diverte e alivia com a suavidade das palavras o peso dos conflitos do outro. Você, querida, foi mais que amiga durante toda essa trajetória. Não sei como agradecer todas as palavras de carinho e atenção, bálsamo oportuno diante das dificuldades do trabalho... 
À amiga Profa. Dra. Josette Monzani. Agradeço a leitura de As Horas Nuas durante suas férias, pelas inúmeras tentativas de encontrar o filme Le ore nude, por nossas divertidíssimas conversas sobre o gato Rahul e Rosa Ambrósio! Obrigada por acreditar no meu trabalho, desde que eu era revisora da revista Olhar.

À minha orientadora, Profa. Dra. Sandra G. T. Vasconcelos. Obrigada por ter me apresentado Antonio Candido e Roberto Schwarz por um novo ângulo, ensinando-me a atentar para a prosa dos textos literários, e também pela orientação segura e pela leitura atenta e precisa dos capítulos desta tese.

Às Profas. Dras. Nadia Battella Gotlib e Tânia Pellegrini, pelo acompanhamento de meu trabalho com Lygia Fagundes Telles há dez anos, incluindo o exame de qualificação deste doutorado. A você, Tânia, agradeço a oportunidade de me iniciar nos caminhos da pesquisa. A você, Nádia, pelos valiosos comentários, pela leitura empenhada de meus relatórios desde a Iniciação Científica, passando pelo mestrado até chegar a essa etapa; pela maneira carinhosa e segura de apontar novas possibilidades para meu trabalho, obrigada.

À Patrícia S. Mastrantonio. Obrigada pelo carinho, pela torcida e pela escuta atenciosa.

Aos meus sogros, Antonio e Antonia, e aos tios Lúcia e José. Obrigada pelo apoio e pelas orações.

Aos funcionários do Departamento de Teoria Literária e Literatura Comparada, especialmente ao Luiz de Mattos Alves, por seu atendimento sempre pronto e gentil, atencioso e humano, sanando todas as dúvidas e facilitando os trâmites burocráticos. Muito obrigada.

Ao Pe. Lázaro Daniel, pelas traduções de italiano, ao meu cunhado, Marcos, e aos membros da comunidade "Filmes antigos" do Orkut, pelas informações valiosas sobre Le ore nude, e especialmente à Sibelly Vieira, por ter cedido gentilmente uma cópia da versão cinematográfica de Doce Pássaro da Juventude e pelo apoio constante.

Ao CNPq, pela bolsa que me foi concedida a partir de abril de 2008 . 
Este trabalho busca investigar o jogo de representação no romance As Horas Nuas (1989), de Lygia Fagundes Telles, a partir da construção da protagonista Rosa Ambrósio. Na recuperação do passado pelo exercício da memória, os papéis femininos por ela outrora desempenhados no teatro como atriz misturam-se ao seu próprio repertório e descortinam a encenação de uma história de sujeição da mulher, suas tentativas de emancipação e a difícil arte de harmonizar a convivência nas esferas pública e privada. A divisão da perspectiva narrativa com um gato dotado de pensamento crítico e com uma onisciência seletiva que apresenta a intimidade da analista da atriz corrobora tanto a relação da protagonista envelhecida com os membros de sua intimidade, quanto desvenda a condição plural das mulheres no Brasil da década de 80. Propomos que os mecanismos de mediação escolhidos por Telles, especialmente o uso da intertextualidade com o teatro e a representação do processo de elaboração do pretenso livro de memórias de Rosa revelam sua experiência social como mãe, esposa, amante, filha, patroa, paciente, e também o diálogo da escritora com o próprio fazer literário. Na tessitura narrativa de As Horas Nuas, com seus limites movediços entre invenção e memória, lembrança e esquecimento, configurados na dialética de expor e ocultar, delineiam-se, entre espelhos e máscaras, as transformações sociais ocorridas com a mulher e com a instituição familiar no país durante quase meio século.

Palavras-chave: representação; mulher; teatro; memória; criação literária. 


\section{ABSTRACT}

This dissertation seeks to investigate the role of representation in the novel As Horas Nuas (1989), by Lygia Fagundes Telles, based on the construction of the protagonist Rosa Ambrósio. By recovering the past through the exercise of her memory, the female roles once performed by her as a theatre actress mingle with her own experience and unveil the enactment of a woman's story of submission, her attempts at emancipation and the difficult art of harmonizing her coexistence in the public and private spheres. The shared point of view between Rosa Ambrósio, a critical cat and a selective omniscient narrator, who presents the intimacy of the actress's psychoanalyst, portrays the relationship of the aged protagonist with those around her and also uncovers women's plural condition in Brazil in the 80's. What we propose is that the mechanisms of mediation chosen by Telles, especially the use of intertextuality with theatrical plays and the intended writing process of Rosa's memoirs, reveal her social background as a mother, wife, lover, daughter, mistress, patient, but also the dialogue of the writer with literary production itself. In the narrative texture of As Horas Nuas, with its unstable boundaries between invention and memory, remembrance and oblivion, configured in the dialectic of exposing and hiding, the social transformations that women and the family as an institution have been through in the country for nearly half a century are delineated between mirrors and masks.

Keywords: representation; woman; theatre; memory; literary production. 


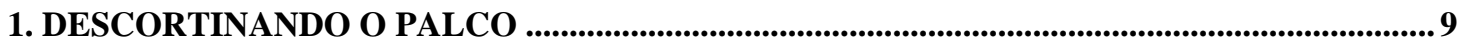

2. TEATRO E REPRESENTAÇÃO: UMA QUESTÃO DE PONTO DE VISTA .............................. 28

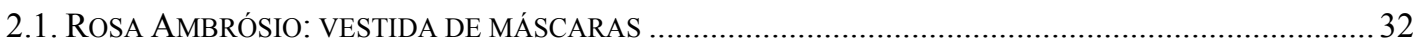

3. CONTRACENANDO NA INTIMIDADE..............................................................................60

3.1. ESPELHO, ESPELHO MEU, EXISTE ALGUÉM MAIS NARCISISTA DO QUE EU? …………….................. 63

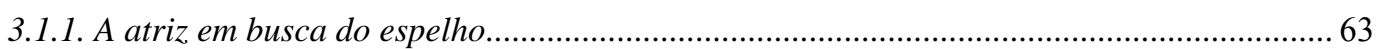

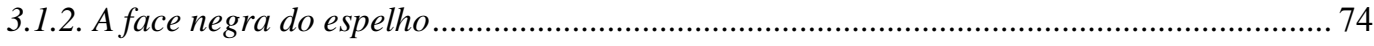

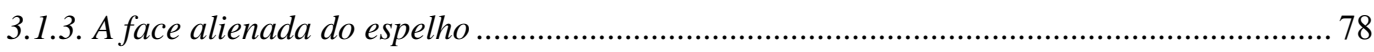

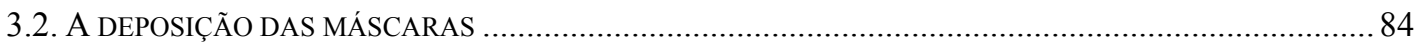

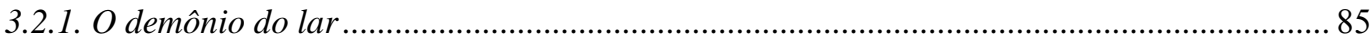

3.2.2. 'Uma bruxa seduzindo o tempo' ............................................................................................. 98

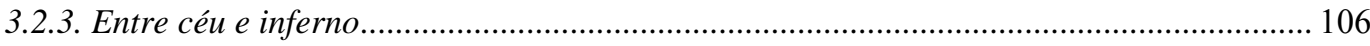

4. AS OUTRAS DIMENSÕES DO ESPELHO_...................................................................12

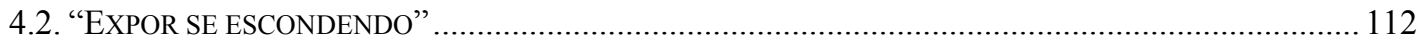

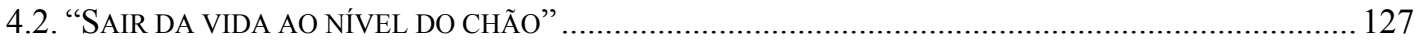

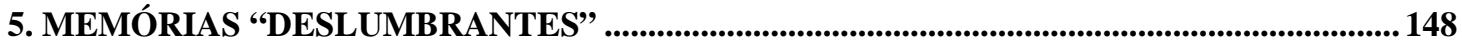

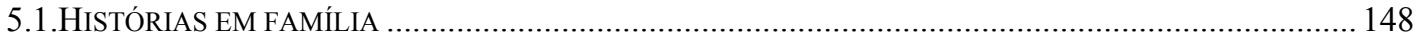

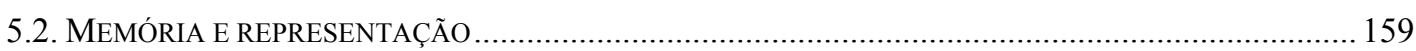

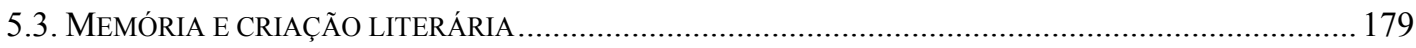

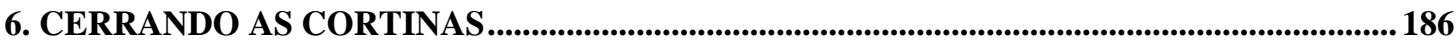

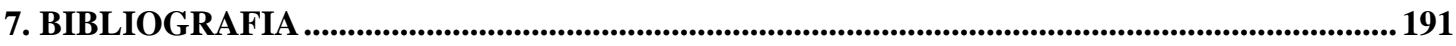

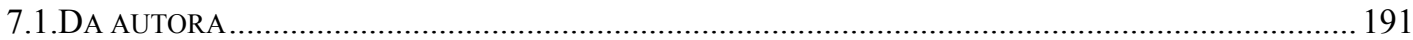

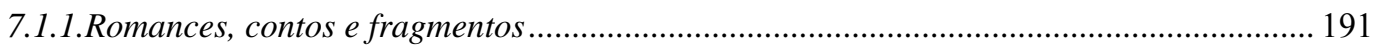

7.1.2.Crônicas, depoimentos e documentários ............................................................................... 192

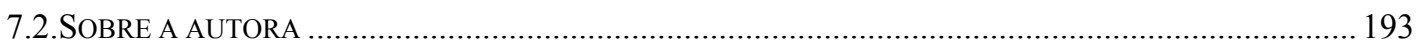

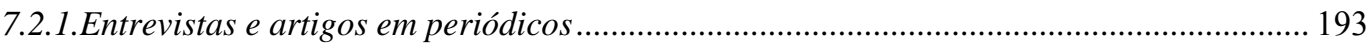

7.2.2.Dissertações, teses, artigos e capítulos de livros................................................................... 195

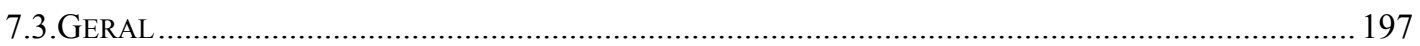


Divendo a realidade de uma escritora de Terceiro Chundo, considero a minha obra de natureza engajada, ou seja, comprometida com a condição humana dentro da circunstância de um pás, participante e testemunha de uma sociedade.

Epgia Gagundes Telles 


\section{DESCORTINANDO O PALCO}

m 1989, Lygia Fagundes Telles publicou seu último romance, As Horas
Nuas, o qual teve uma recepção controversa, como as resenhas em jornais e revistas, à época do lançamento do livro, podem atestar. Lygia foi acusada, por exemplo, de ter deixado "cair a peteca" nesse romance que tinha "tudo para ser ótimo", mas "que acaba sendo apenas bom", uma vez que a "romancista fugiu para o policial e para o romântico" no final do livro, "beirando o pior clichê", ; mas também foi aclamado como "não só o seu melhor romance, mas um dos melhores dos dias que correm", com "a nobreza patética de um vitral enlameado", em que a escritora surge como uma "atenta observadora social"3. $\mathrm{O}$ leitor acostumado com as especificidades da prosa lygiana, nos diversos contos e nos três romances anteriormente publicados, pode verificar, apesar de opiniões opostas como aquelas, que a autora alcança uma técnica apurada e um desenvolvimento singular de boa parte das características estilísticas, marcantes em sua extensa obra ficcional, como o tratamento peculiar dado ao tempo, o olhar subjetivo que permite a redução da distância entre as personagens e o leitor, numa atmosfera em que os objetos dispostos encontram-se intimamente ligados à caracterização das personagens, os quais concorrem para o desenvolvimento de temas caros à escritora desde seus primeiros contos. Nas palavras de Nelly N. Coelho, “focalizadas sempre no plano das relações humanas, as personagens que habitam seu mundo ficcional são todas criaturas interiormente desarvoradas, perdidas em si mesmas, afundando-se na própria consciência como em areias movediças."4

Sua vasta galeria de personagens, formada em grande parte por figuras femininas e de classe social privilegiada, sofre com a desestruturação e decadência da família, burguesa em sua maioria, com a solidão, com a rejeição, com a degradação dos costumes, com a ausência

\footnotetext{
${ }^{1}$ SANTIAGO, Silviano. Romance traz o tango das ilusões perdidas. Folha de São Paulo, São Paulo, 20 maio 1989. Ilustrada, p. G-6.

${ }^{2}$ MARTINS, Wilson. Trechos de crítica sobre o romance As Horas Nuas. Original Datilografado, s/d. Disponível em: $<$ http://literal.terra.com.br/ligia_fagundes_telles/Novidades_Lygia/Mais/Trechos_de_cr\%EDticas_do_livro_As_ Horas_Nuas.pdf> Acesso em: 18 nov. 2008.

${ }^{3}$ ABREU, Caio Fernando. As horas de Lygia. Isto é Senhor, 21 jun. 1989. Seção Cultura, p. 88.

${ }^{4}$ COELHO, Nelly N. O mundo de ficção de Lygia Fagundes Telles. In: TELLES, Lygia Fagundes. Seleta. Organização, estudo e notas da Profa. Nelly N. Coelho. 3. ed. Rio de Janeiro: José Olympio, 1978, p.139. (Coleção Brasil Moço).
} 
da figura paterna, com a condição da mulher na sociedade brasileira, com a incomunicabilidade dos seres, com a morte, com a velhice, com o fantástico, com a loucura e o desencontro, como sua produção ficcional pode comprovar. Esses temas também surgem, em maior ou menor medida, no romance em questão com nova roupagem e numa linguagem carregada pela ambiguidade, pelo humor e pela ironia, em que o tênue limite entre invenção e memória ${ }^{5}$, e entre a possibilidade de representar e a necessidade de extrapolar as fronteiras do convencional são ainda mais evidentes.

Em “As Horas Nuas, um jogo de deciframento”, por exemplo, Vera M. T. Silva afirma que o livro se alimenta de contos e romances anteriores da própria escritora, o qual não se constitui numa "espécie de colcha de retalhos, como costumam ser os best-sellers, recombinando ingredientes narrativos que deram certo para iludir o leitor", mas num "livro de coroamento, que congrega e ultrapassa as obras anteriores da autora" ${ }^{\text {, }}$, graças ao esforço de construção textual do romance. Isso se explica pelo fato de que Lygia coleciona e põe em jogo $^{8}$ as palavras, em uma escrita paradoxalmente intimista e marcada pelo sentimento de tempo e de lugar, o que fica mais evidente em seus romances, com a preocupação de dar testemunho, a partir da exploração da subjetividade de suas personagens, especialmente as femininas, das transformações da vida cotidiana de um país como o Brasil desde a segunda metade do século XX.

Lygia revela, no primeiro dos dezoito capítulos que compõem As Horas Nuas, a rica subjetividade de Rosa Ambrósio, uma velha atriz em décadence, a partir de um monólogo interior delirante, graças ao estado de embriaguez em que ela se encontra. O leitor descobre

\footnotetext{
${ }^{5}$ Em sua produção mais recente, a escritora mostra-se preocupada justamente com esses limites, principalmente nos livros em que fatos supostamente autobiográficos e ficção são tema, como Invenção e memória, Durante aquele estranho chá e Conspiração de nuvens.

${ }^{6}$ SILVA, Vera M. T. As Horas Nuas, um jogo de deciframento. In: A ficção intertextual de Lygia Fagundes Telles. Goiânia: CEGRAF/UFG, 1992, p. 29. Nos próximos capítulos da tese, ficarão evidentes algumas características de estilo, temas e estratégias na construção dos protagonistas que aproximam As Horas Nuas dos romances e os contos anteriores da escritora, num caminho um pouco diferente do que foi trilhado pela autora citada. Neste trabalho, mostraremos como alguns traços das personagens da obra pregressa de Telles estão presentes na composição de Rosa, Gregório e outros personagens de As Horas Nuas.

${ }^{7}$ Ibid., p.30.

${ }^{8}$ Em inúmeras entrevistas e depoimentos, Lygia compara o ato de escrever ao de jogar, gosto que herdara de seu pai, que apostava em roletas. Seu jogo, no entanto, é com as palavras, do qual depende uma parceria com o leitor. Além dessa, outra metáfora pode ser apreendida da leitura de sua produção ficcional: são os atos de colecionar e guardar. A escritora coleciona as palavras como os vaga-lumes e outros insetos que caçava e fechava em pequenas caixas de sabonete durante a infância ou as frutas que colocava nas gavetas e que só eram retiradas quando já amadurecidas. Segundo a escritora, “(...) Teria nascido nesse tempo o antigo instinto de permanecer, de se valer da arte para assim ficar. Resistir. A esperança de infinito na nossa finitude". In: TELLES, Lygia F. A criação literária. No princípio era o medo. Original datilografado. s/d. Disponível em: $<$ http://literal.terra.com.br/ligia_fagundes_telles/Novidades_Lygia/Mais/A_cria\%E7\%E3o_Liter\%E1ria__Lygia.pdf> Acesso em: 18 nov. 2008.
} 
que Rosa deseja escrever um livro de memórias, ao mesmo tempo em que desfilam os medos e as preocupações da protagonista, como o terror da velhice e da solidão, sua indignação com as mazelas sociais que assolavam o Brasil de então, os perfis esboçados daqueles que fizeram e fazem parte de sua história de vida. Um emaranhado de lembranças - memória ou invenção? - em que marido, pai, amante, mãe, filha, empregada, analista - aqueles que participam de sua experiência doméstica e social- estão 'embrulhados' como a própria atriz, os quais, ao longo do romance, ela tenta 'desembrulhar' para compreender a si própria e sua história, com seus fracassos e vitórias.

Terminada a leitura desse primeiro capítulo, o leitor acredita que terá pela frente novas páginas agônicas, mas bem humoradas, das 'memórias' da atriz. Essa expectativa será satisfeita posteriormente, pois, no segundo capítulo, ele depara-se surpreendentemente com um gato dotado de memória, Rahul, resgatando, através de 'um furo no tempo', cenas breves, mas carregadas de lirismo, de suas outras vidas, quando fora um atleta, um poeta homossexual na Roma Antiga, um menino de cachos que morava na casa das venezianas verdes... Ao longo do romance, esse gato, como ser ambíguo, tece comentários irônicos sobre a condição de Rosa Ambrósio, a das demais personagens e a própria.

Um terceiro ponto de vista, no entanto, traz à tona as divagações e sentimentos da analista da atriz, Ananta Medrado - uma personagem secundária que ganha relevo ao longo da narrativa paradoxalmente quando desaparece sem deixar vestígios e pistas aparentes-, e posteriormente, de Renato Medrado, que toma as rédeas da investigação sobre o sumiço de sua prima Ananta. A analista fazia plantões na Delegacia da Mulher e participava com frequência de debates e discussões universitárias, empenhada em trabalhar ativamente em programas que defendessem os direitos da mulher.

$\mathrm{O}$ último romance de Telles se organiza em torno do jogo da exposição e do ocultamento, seu princípio estruturante, e nesse jogo, frases ou expressões, enunciadas principalmente por Rosa, em vários momentos do texto, normalmente só fazem sentido para o leitor em capítulos posteriores ou até mesmo anteriores, quando as referências tornam-se completas, o que faz pensar que o livro apresenta uma forma semelhante à de um espiral, com seu característico movimento circular que nunca se fecha. A própria autora afirmou que as novidades de As Horas Nuas com relação aos seus romances anteriores podem ser encontradas na figuração de uma protagonista em plena maturidade e no uso da linguagem: "Neste romance, eu crio uma forma diferente. Eu adaptei uma linguagem de acordo com a 
trama e as personagens" ${ }^{\prime 9}$. Como romance fragmentado, a começar das diferentes perspectivas narrativas, As Horas Nuas apresentam um enredo aparentemente simples, ao qual corresponde, no entanto, a complexidade das personagens que "não se esgotam nos traços característicos, mas têm certos poços profundos de onde podem jorrar o desconhecido e o mistério" ${ }^{10}$. Basicamente, as ações que se desenvolvem no presente referem-se apenas ao fato de Rosa estar embriagada e divagar em seu apartamento, recebendo as raras visitas de Cordélia ou fazendo pouquíssimas sessões de análise com Ananta. Tais ações têm como pano de fundo um momento de profunda descrença no Brasil 'redemocratizado', após vinte e um anos de censura e repressão, que culmina com uma inflação galopante, com a corrupção gritante nas esferas do poder e com a expansão desordenada das grandes cidades, alterando os modos de vida e os códigos de produção de bens e de consumo. As duas últimas personagens moram no mesmo prédio, onde Rosa e seu gato ficam confinados ao longo de todo o romance. A atriz desloca-se do edifício apenas em dois momentos: quando vai ao consultório do médico indicado pela amiga Lili, de onde sai desesperadamente e segue de táxi rumo à Praça da República, local em que 'reencontra' os fantasmas do passado; e no final do romance, quando o leitor descobre, por meio do discurso de Renato Medrado, que Rosa internara-se voluntariamente em uma clínica de desintoxicação, para 'entrar em forma' a fim de voltar aos palcos e esperar o regresso de Diogo, seu amante. Antes dessa internação voluntária, o fato que dá um novo ritmo ao romance é o desaparecimento de Ananta, quando um clima de romance policial toma conta da última parte do livro. A verdadeira riqueza deste texto de Telles encontra-se na exploração da subjetividade de Rosa e de Rahul, os quais se nutrem do passado, com suas glórias e fracassos, aliada ao engenhoso trabalho de tripartição da perspectiva narrativa em que a personagem analista, como veremos, surge também como parte indissociável da caracterização da protagonista $^{11}$. As Horas Nuas também evocam uma perspectiva feminista ao colocar em alto relevo, como personagens efetivamente atuantes, figuras femininas, em detrimento de personagens masculinas, as quais, no presente da narrativa, encontram-se mortas ou têm paradeiro desconhecido. É mais rica, porém, a matéria

\footnotetext{
${ }^{9}$ VASCONCELOS, Ana Lúcia. Lygia Fagundes Telles - Crio um livro como uma colcha de retalhos. Leia, São Paulo, maio 1986. Disponível em: <http://www.cronopios.com.br/site/artigo.asp?id=3696> Acesso em: 08 dez. 2008.

${ }^{10}$ ANTONIO Candido. A personagem do romance. In: ANTONIO Candido et al. A personagem de ficção. 11. ed. São Paulo: Perspectiva, 2007, p.60.

${ }^{11}$ Nesse aspecto, minha visão sobre a tripartição da perspectiva narrativa no romance difere do olhar de Nízia Villaça, para quem "a necessidade de tamanha variedade de focos narrativos parece provir da preocupação em não cair no romance autobiográfico, intimista". In: VILLAÇA, Nízia. O olhar Barroco. In: Paradoxos do PósModerno: sujeito \& ficção. Rio de Janeiro: Editora da UFRJ, 1996, p. 135.
} 
que viceja no romance, se comparada à limitada tentativa de captar - se é possível - seu 'enredo'.

A estratégia narrativa de Lygia Fagundes Telles em As Horas Nuas revela também um diálogo com a tradição do romance, na medida em que ela aciona as conquistas que o gênero incorporou em favor de uma visão própria do fazer literário, que se traduz no profundo sentido estético do romance em questão. $\mathrm{O}$ tratamento dado às categorias de tempo e espaço; a necessidade de retorno, pela imaginação/criação, a um tempo anterior ou mítico como Rahul e a própria Rosa desejam; a referência à e a intertextualidade com a arte dramática; o diálogo com o romance policial e com as memórias e o fato de As Horas Nuas não oferecerem apenas um ponto de vista, com as impressões e lembranças de Rosa reproduzidas, mas uma pluralidade de focalização, são alguns indicativos daquele diálogo com a tradição de um gênero enciclopédico como o romance. Cabe destacar que tal multiplicidade de pontos de vista tem, neste trabalho, tanto a intenção de compreender a 'verdadeira' Rosa Ambrósio, circunscrevendo sua relação com os membros de sua intimidade, como é o caso de Rahul, quanto de revelar, por oposição, outros matizes da condição da mulher, a partir de Ananta. O desejo de aproximação da realidade mediante outras impressões subjetivas, obtidas em diferentes personagens, distingue-se do subjetivismo unipessoal da atriz, em que sua própria visão de realidade como aquela que se expressa unicamente é tida como a que apresenta validade. $^{12}$

Se as referências aos seus livros anteriores são evidentes em As Horas Nuas, em que situações e personagens com nomes idênticos ou não às personagens deste romance voltam com força, isto se dá graças ao trabalho de atualização e recriação do ambiente, do detalhamento e afloramento do que está escondido, encoberto, nas personagens, revelando, em especial, a preocupação com o fazer literário. O valor metafórico e/ou simbólico de nomes, de componentes do cotidiano, de animais e corpos celestes é relevante para a estrutura do texto, pois estes elementos não funcionam como termos acessórios, banais ou casuais na prosa fluente do romance; antes, assumem o papel de revelar aspectos que contribuem para a

\footnotetext{
${ }^{12}$ Erich Auerbach mostra que esse procedimento, guardadas suas especificidades, é característico do estilo de Virginia Woolf. Segundo a análise que o crítico faz de um trecho do romance To the Lighthouse, no episódio em que Mrs. Ramsay faz a medição da meia da 'cor de urzes' na perna de seu filho James, várias impressões subjetivas a respeito da protagonista e de outras personagens emanam a partir do uso do discurso indireto livre. Em As Horas Nuas, os vários pontos de vista, como impressões subjetivas, surgem a partir do monólogo da protagonista, do fluxo de consciência de Rahul e do discurso indireto livre em que Ananta se manifesta, em capítulos distintos, como se estivessem reservados à 'voz' de cada uma dessas personagens, de acordo com sua entrada em cena. Este é, pois, o aspecto que difere a técnica utilizada por Lygia da que foi usada por Virginia Woolf, com a qual a escritora brasileira dialoga. Cf. AUERBACH, Erich. A meia marrom. In: Mimesis - A representação da realidade na literatura ocidental. 3. ed. São Paulo: Perspectiva, 1994.
} 
manutenção ou solução da ambiguidade, da relação entremeada do dito e do não-dito, em que o medo e a esperança andam de mãos dadas. Neste e em outros dos seus textos, a autora é capaz de "fixar um momento fugaz, um instante, um simples gesto, a intimidade do pensamento. Para isso, funcionam o símbolo e o duplo sentido nos gestos e nas palavras"13. As reedições de sua produção ficcional, como a mais recente, iniciada em 2009 com a publicação de sua obra pela Companhia das Letras ${ }^{14}$, permitem que ela 'retoque' seus textos, na tentativa de aperfeiçoá-los, buscando no exercício constante do jogo com a palavra escrita aquela mais adequada, a que possa carregar a força capaz de estender a ponte entre a autora e seu leitor - a forma que ela encontrou de conseguir o amor do próximo, já que a compreensão é mais difícil, como faz questão de afirmar. Para dizer com Vicente Ataíde, "Lygia tem o que dizer e por isso há um constante vigiar-se a fim de que venha a dizer as coisas de maneira

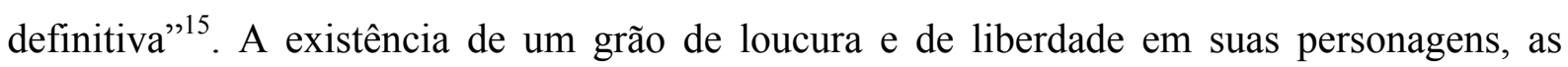
quais 'gostam da vida como nós' ${ }^{16}$, é uma das maneiras que a escritora encontra para tornar o leitor seu cúmplice: que ele tenha a mesma liberdade que a escritora para decidir o que possa ser invenção ou realidade, o que foi vivido ou inventado, se o real é mais ou menos real que a realidade.

O Prêmio Camões, a maior premiação oferecida a escritores de Língua Portuguesa, conferido à escritora de As Horas Nuas em 2005, confirma o reconhecimento da qualidade literária de seus contos, romances e fragmentos e também do que a autora representa na história da literatura brasileira. Com parte de sua obra traduzida em diversos países e ocupante da cadeira de $\mathrm{n}^{\circ} 16$ da Academia Brasileira de Letras, para a qual foi eleita em 1985, Lygia considera D. H. Lawrence, Marcel Proust, Jorge Luis Borges, Virginia Woolf, Edgar Allan Poe, Álvares de Azevedo, William Faulkner, James Joyce, Oscar Wilde, Henry James, Doris Lessing, Machado de Assis como os romancistas e contistas que funcionam como suas "almas

\footnotetext{
${ }^{13}$ JOSEF, Bela. A arte de Lygia Fagundes Telles. In: O jogo mágico. Rio de Janeiro: José Olympio, 1980, p. 94.

${ }^{14}$ A nova edição de As Horas Nuas foi lançada oficialmente em 30 de abril de 2010, o que impossibilitou sua utilização como referência nesta tese, concluída em julho desse mesmo ano. As modificações feitas por Lygia são breves, mas em alguns trechos do romance, a escritora alterou frases inteiras, retirando expressões e acrescentando novas orações. Se por um lado, esse trabalho artesanal de aprimoramento de sua linguagem derrubou algumas ambiguidades, tornando algumas passagens mais claras, por outro, esvaziou uma personagem como Rahul, por exemplo, de um certo mistério, em alguns excertos.

${ }^{15}$ ATAÍDE, Vicente. A narrativa de Lygia Fagundes Telles. In: A narrativa de ficção. 2. ed. São Paulo: McGraw-Hill do Brasil, 1973, p. 92-93.

${ }^{16}$ TELLES, Lygia Fagundes. Personagens gostam da vida, como nós. O Estado de São Paulo, São Paulo, 12 out. 1995. Caderno 2, p. D-5.
} 
gêmeas"17. Mas a influência do Bruxo do Cosme Velho é inegável do ponto de vista da construção textual, propício às divagações e reflexões, às "abelhudices do narrador" que, no entanto, não são meros artifícios de linguagem no romance machadiano mas, sim, parte de uma composição rigorosa, em que transparece o método nas "manhas narrativas do

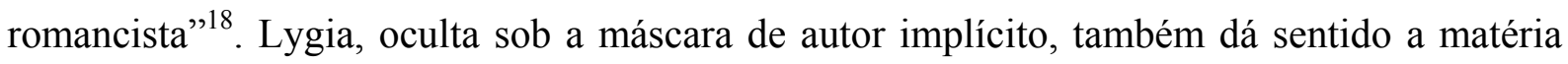
romanesca aparentemente desconexa, com movimentos de avanço e recuo. Nesse sentido, As Horas Nuas, aparentemente, não é um romance que se quer conjunto, mas dispersão. Dispersão no sentido de uma necessária consciência de descentralização da 'verdade', revestida pelo disfarce da unidade do eu. Apenas um narrador, protagonista como Raíza, de Verão no Aquário (1963), ou a onisciência que acompanha Virginia, de Ciranda de Pedra (1954), já não são capazes de contar e mostrar em As Horas Nuas, pois uma única posição não pode abarcar sua complexidade. Assim, a convivência de múltiplos pontos de vista narrativos surge como um aspecto fundamental, relativo à técnica, que concerne mais diretamente ao delineamento da experiência social da protagonista, Rosa Ambrósio, embora este recurso não constitua propriamente uma novidade em As Horas Nuas. A autoapresentação de três protagonistas já tinha sido utilizada pela autora em As Meninas (1973), romance no qual Lorena, Lia e Ana Clara, como personagens e vozes narrativas, oriundas de classes sociais diversas, convivem em um mesmo espaço (um pensionato), numa mesma cidade (São Paulo), durante a ditadura militar imposta em 1964 e constituem as três faces de uma pirâmide, as quais se sustentam como possíveis retratos de mulheres jovens do período em que o livro foi publicado, na década de $70 .^{19}$

Embora seja identificada por muitos leitores e críticos como escritora 'feminista' visão também por mim compartilhada-, Lygia prefere ser lembrada como autora comprometida com seu tempo - e nesse sentido, também questionadora da problemática da mulher. A crítica feminista de orientação cultural oferece subsídios interessantes para a análise da especificidade da escrita das mulheres, inclusive as "importantes diferenças entre as mulheres escritoras", tais como "classe, raça, nacionalidade e história", as quais são

\footnotetext{
${ }^{17}$ INSTITUTO MOREIRA SALLES. Cadernos de Literatura Brasileira n.5 - Lygia Fagundes Telles. São Paulo: IMS, março de 1998, p. 30-31.

${ }^{18}$ SCHWARZ, Roberto. Complexo, Moderno, Nacional, e Negativo. In: Que horas são? 2. ed. São Paulo: Companhia das Letras, 2006, p. 115.

${ }^{19}$ SANTOS, Ana Paula dos. O eu e o outro: retratos de mulheres em dois romances de Lygia Fagundes Telles. Dissertação (Mestrado em Estudos Literários). Faculdade de Ciências e Letras, Campus de Araraquara, Universidade Estadual Paulista, 2004, 153 p.
} 
“determinantes literários tão significativos como o gênero" (gender $)^{20}$. Nesse aspecto, tal vertente crítica reconhece a escrita das mulheres como o lugar privilegiado para a experiência social feminina e um de seus méritos remete à tentativa sistemática de recuperação da produção feminina silenciada ou excluída dentro dos cânones literários, desmascarando as estratégias sociais e políticas opressoras da instituição literária e dos aspectos culturais da análise que envolve a produção literária feita por mulheres.

O título de escritora feminista atribuído a Lygia por parte da crítica deve-se ao fato de que, em muitos de seus textos literários, ela tem registrado uma sociedade cujos valores entram em franca desagregação, quase sempre do ponto de vista da mulher, cuja revolução nos papéis que lhe foram tradicionalmente atribuídos teve alcance mundial e transformou as relações profissionais e pessoais nessa 'era de extremos' ${ }^{21}$, para usar a expressão de Eric Hobsbawm. Seus romances anteriores, Ciranda de Pedra (1954), Verão no Aquário (1963) e As Meninas (1973), permitem entrever mudanças na sociedade brasileira a partir das personagens femininas que os protagonizam ${ }^{22}$. Há uma característica comum às personagens dos romances de Lygia: a busca do espaço da 'rua', de modo que elas passaram a integrar outras esferas da vida social, a partir do momento em que saíram da 'casa', do local da domesticidade por excelência, repleto de sentidos de opressão e confinamento, para exercer atividades remuneradas fora do lar. Esse fator de ordem econômica possibilitou uma maior independência em relação à figura masculina, tanto financeiramente quanto em relação à conquista da liberdade de fazer suas próprias escolhas, e deu início ao processo de autointegração da mulher, apesar das imposições que a sociedade e a família mantiveram e ainda mantêm a fim de preservar o modelo da "segunda mulher" - 'belo sexo', 'fada do lar', educadora dos filhos. ${ }^{23}$

No início dessa trajetória posta pela ficção de Lygia, Virgínia, protagonista de Ciranda de Pedra (1954), é a única personagem do romance que obtém sua auto-integração, devido à escolha de se desvencilhar da dependência econômica do pai e da falta de afeto dos demais membros da esfera familiar e da rede social em que estava inserida. A opção de seguir uma

\footnotetext{
20 SHOWALTER, Elaine. A crítica feminista no território selvagem. In: HOLLANDA, Heloísa B. (org.). Tendências e impasses: o feminismo como crítica da cultura. Rio de Janeiro: Rocco, 1994, p.44.

${ }^{21}$ HOBSBAWM, Eric. Era dos extremos - o breve século XX: 1914-1991. Tradução Marcos Santarrita; revisão técnica Maria Célia Paoli. São Paulo: Companhia das Letras, 1995.

${ }^{22}$ SANTOS, Ana Paula dos. Algumas mulheres de Lygia Fagundes Telles. Relatório Final de Bolsa de Iniciação Científica - FAPESP, sob orientação da Profa. Dra. Tânia Pellegrini. São Carlos, 2000, 145p.

23 LIPOVETSKY, Gilles. A terceira mulher- permanência e evolução do feminino. Tradução Maria Lucia Machado. São Paulo: Companhia das Letras, 2000, p. 236.
} 
viagem sem rumo configura-se na representação simbólica de que novos caminhos para a mulher de classe média estavam se esboçando, cujos contornos ainda não estavam completamente delineados, pois as condições e valores sociais do período - a década de 1950ainda não eram totalmente favoráveis para que uma mudança radical como aquela pudesse ocorrer efetivamente. Os pilares da sociedade patriarcal - a família, a tradição, a propriedade ainda encontravam-se fortemente fincados, como pode comprovar o fato de Laura, mãe da protagonista, ser punida pela escritora com a loucura, por seu ato de adultério.

Em Verão no Aquário e em As Meninas ${ }^{24}$, a lente da escritora continuou a captar com precisão traços de classe das personagens femininas - que também podem ser caracterizados como identidades de gênero $^{25}$ - que continuavam a busca de realização de seus anseios. A protagonista Raíza, do primeiro, parece ter aprendido a lição de tentar descobrir a própria vocação com Virgínia e, principalmente com sua própria mãe, Patrícia, uma mulher forte que transforma a literatura que produz no ganha-pão capaz de sustentar a família, numa clara tentativa de Lygia tanto de inserir a figura da mulher como escritora, quanto de subverter a imagem de que apenas os homens escritores poderiam 'viver da pena' ou das artes em geral. Em Verão no Aquário, o processo gradativo da decadência da família burguesa, representado em Ciranda de Pedra, tem continuidade com as transformações sensíveis de seus valores mais preciosos, como a moral, a fé católica e a noção de propriedade e de família. Seu final também em aberto para as personagens, em especial as femininas, distancia-se das frustradas tentativas das protagonistas de As Meninas por apresentar a auto-integração de Raíza e de sua prima Marfa como o sinal da esperança de novos tempos e conquistas para a mulher do período em que o romance foi publicado (1963), quando a contestação passa a ser uma das palavras de ordem a fim de promover mudanças de âmbito político, social, econômico e cultural, mesmo com a pesada sombra de um golpe militar que se articulava.

No contexto da ditadura, o ponto de vista da mulher, em As Meninas, publicado em 1973, deflagra uma série de desencontros: o medo do qual Raíza tinha se libertado retorna ainda mais poderoso e amedronta de modo mais intenso as protagonistas Lorena, Lia e Ana Clara, personagens de classes sociais distintas, convivendo em um espaço intermediário entre a casa e a rua - o Pensionato Nossa Senhora de Fátima. Se Raíza tem plena consciência de seu

\footnotetext{
${ }^{24}$ SANTOS, Ana Paula dos. O eu e o outro: retratos de mulheres em dois romances de Lygia Fagundes Telles. Op.cit., passim.

${ }^{25}$ No sentido aqui proposto, identidades de gênero remetem às “(...) feminilidades e as masculinidades que se produzem no encontro de "gênero" com classe, raça/etnicidade, orientação sexual, em diversas constelações históricas". ADELMAN, Miriam. O gênero na construção da subjetividade: entendendo a 'diferença' em tempos pós-modernos.... In: ADELMAN, Miriam; SILVESTRINI, Celsi B. (orgs.) Gênero Plural (coletânea). Curitiba: EdUFPR, 2002, p. 57.
} 
processo de transformação, Lorena, Lia e Ana Clara encontram-se a meio caminho da tão desejada auto-integração. Além da impossibilidade de equilíbrio com o meio, essas personagens deparam-se a todo instante com a figura masculina e, consequentemente, com algumas implicações negativas atribuídas a essa figura central do patriarcado, das quais o medo parece ser uma das mais atuantes. Embora o casamento e a maternidade percam a função de fins últimos para a mulher, a instituição do matrimônio carrega os resquícios da "necessidade" de estabilidade econômica e da suposta segurança, num país marcado pela supressão do direito à liberdade de expressão e pela modernização desordenada que atinge as metrópoles mais desenvolvidas.

De Virgínia a Rosa Ambrósio, protagonista de As Horas Nuas, a escritora revela, no trato das personagens, representações do percurso da modificação dos lugares ocupados pela figura feminina que, iniciado em meados da década de 1950, transforma-se radicalmente nas décadas de 1970 e 1980. Essa trajetória passa da luta por um espaço de expressão e atuação da nova mulher, com Virgínia, à constatação de uma abertura à participação da mulher paradoxalmente voltada contra si mesma, revelada na construção de Rosa. Esta personagem pode ser considerada 'uma novíssima mulher', que se assusta com a influência da televisão, com a velocidade da informação do mundo globalizado, com a espetacularização da intimidade, bem como com a chegada da velhice e os aspectos negativos que se atribuem a essa nova faixa etária, cujo medo do preconceito, calcado na protagonista e no outro, impossibilita a continuidade de atuação nas relações profissional e pessoal.

Assim, na produção ficcional de Lygia - especialmente em seus romances-, as mulheres conquistam o mais importante direito: o de provar o poder de sua palavra. A grande aprendizagem de Raíza, Marfa, Lorena, Lia, Ana Clara, Ananta e Rosa Ambrósio, iniciada com Virgínia, consiste no exercício de se expressar por palavras e apostar no poder que elas têm. Essa posição diferencia a escritora no cenário da produção literária contemporânea brasileira em que, ainda no final do século $\mathrm{XX}$, no que se refere à literatura feita por mulheres, "cada escritora tende a ser vista como representante de uma certa 'dicção feminina' típica, em vez de reconhecida como dona de uma voz autoral própria" ${ }^{26}$. Lygia garante sua posição de escritora que construiu solidamente sua carreira porque, no momento em que

\footnotetext{
${ }^{26}$ DALCASTAGNÈ, Regina. A personagem feminina na narrativa brasileira dos anos 90. In: PIRES, Maria Isabel E. (org.). Formas e dilemas da representação da mulher na literatura contemporânea. Brasília: Editora da Universidade de Brasília, 2008, p. 101. A autora discute aí justamente o problema de que a produção literária feita por mulheres continua sendo rotulada como 'literatura feminina', que se contrapõe à 'literatura', sem a adjetivação masculina, mas que remete à produção feita por homens.
} 
escreve e busca o aperfeiçoamento de sua escrita, afirma que tudo é posto de lado: “(...) Esqueço. Estendo minhas antenas e como um inseto subindo pelo áspero casco de uma árvore faço minha escolha e sigo meu caminho. É difícil. É duro. Mas já optei. Carrego comigo a alegria dessa opção" ${ }^{\text {27 }}$. Sua carreira como escritora iniciara-se ainda na década de 1940, quando publicou, com os recursos de seu pai, Porão e Sobrado, livro que, juntamente com Praia Viva e parte de O cacto vermelho, é renegado pela autora por não se constituir o melhor que pôde produzir - ambos os livros não apresentam o comprometimento e as preocupações de uma escritora que se formaria posteriormente num momento da História em que "o planeta está enfermo" e em que o Brasil continua um "país imaturo", com tantas desigualdades sociais como o acesso restrito, de uns poucos, à educação e saúde de qualidade. Em Seleta, a escritora afirma, quanto aos seus primeiros livros de contos e ao processo de reelaboração de textos antigos, que

naquela ocasião eu não sabia ou, pior ainda, não ousava escrever certas coisas, chegar a determinadas soluções [...] Devo confessar que, não resistindo ao fascínio da tarefa artesanal, fiz cortes, acrescentei, reajustei, mas sem alterar a fisionomia original de cada trabalho. ${ }^{28}$

Uma classificação da escritora como pertencente à 'Geração de 45', marcada pela influência do existencialismo do pós-guerra, como querem alguns críticos, por exemplo, não é capaz de enquadrar sua produção ficcional confortavelmente. Seus contos e romances comprovam, no entanto, a constante transformação de sua técnica e de seus temas, de acordo com as preocupações com o meio e com o momento. $\mathrm{O}$ veio intimista ligado ao social, distante, porém, do "realismo horizontal e raso da ficção tradicional, onde a dimensão vivencial das personagens é apreendida apenas num psicologismo epidérmico" 29 , a liberdade formal e o engajamento em forma de problematização da relação homem-sociedade - mais especificamente mulher-sociedade-, permanece como forte característica desde seus primeiros trabalhos, o que pode, deste modo, justificar aquela 'classificação'. Embora alguns esparsos nomes femininos já fossem 'dignos de nota' como Júlia Lopes de Almeida, Rachel de Queiróz e Lúcia Miguel-Pereira, num cenário literário exclusivamente masculino, é com as obras de Clarice Lispector e da escritora paulistana, nas décadas de 40 e 50, que se consolida um espaço para a literatura feita por mulheres no Brasil, abrindo caminho para as novas

\footnotetext{
${ }^{27}$ COELHO, Nelly N. Encontro com Lygia. In: TELLES, Lygia Fagundes. Seleta. Op.cit., p. xii. (Coleção Brasil Moço)

${ }^{28}$ Id., O mundo de ficção de Lygia Fagundes Telles. In: TELLES, Lygia Fagundes. Seleta.Op.cit., p. 141.

${ }^{29}$ Ibid., p. 138.
} 
gerações de escritoras, como Zulmira Tavares, Lya Luft, Helena Parente Cunha, Marina Colasanti, Nélida Piñon, Marilene Felinto, Conceição Evaristo, Ana Miranda, Márcia Denser, entre outras.

O momento em que Lygia publica seu primeiro romance, Ciranda de Pedra (1954) coincide com uma tendência ao autodescobrimento da mulher escritora, à sua busca por uma identidade, apontada por inúmeras estudiosas no terreno da teoria e da crítica literária feminista, como a terceira fase -especificamente denominada feminil ou fêmea- do desenvolvimento de qualquer subcultura literária ${ }^{30}$, no caso, da literatura produzida por mulheres no Brasil. Tal etapa teria sido precedida por outras duas: a primeira, denominada feminina, consistiria na imitação e internalização de modelos da tradição dominante, de padrões de arte e de visões dos papéis sociais; e a segunda, feminista, corresponderia à de protesto contra esses padrões e valores, incluindo o desejo de autonomia e luta pelos direitos das minorias. No contexto brasileiro, à primeira fase corresponderia a produção de mulheres escritoras no século XIX, que se resumiriam, com algumas exceções, ao "endosso ao sistema" ${ }^{31}$ proposto e a uma espécie de queixume à impossibilidade de autorrealização, ao "destino de mulher", apontado por Beauvoir em O segundo sexo. Observa-se que as duas fases subsequentes - a feminista e a feminil- desdobram-se naquilo que Nelly N. Coelho considera três movimentos de conscientização da mulher escritora e que têm início nos anos 30/40, perpassam as décadas de 40/50 e alcançam os idos de 1960/1980, com características mais ou menos definidas. Isso não significa que tais características possam ser aplicadas como regra geral mas que, como tentativa de sistematização, contribuem para delinear o crescimento e fortalecimento daquela conscientização da mulher como escritora em nosso país. No primeiro período, as escritoras brasileiras constatam o bloqueio imposto pela tradição patriarcal à liberdade de escolha da mulher e lutam em favor da valorização da capacidade intelectual da mulher, mantendo, no entanto, a resignação à imagem feminina. No segundo momento, em que despontam os nomes de Clarice Lispector, Helena Silveira e Lygia Fagundes Telles, há, segundo Coelho, uma espécie de rompimento com a visão tradicional da

\footnotetext{
${ }^{30}$ Essa descrição é feita por Elaine Showalter, a partir da análise da tradição de romancistas inglesas, desde Brontë até Doris Lessing. SHOWALTER, Elaine. A literature of their own - from Charlotte Brontë to Doris Lessing. Princeton, Princeton UP, 1977, p.11-15. É interessante observar que tanto a classificação de Showalter quanto a da brasileira Nelly N. Coelho, provável leitora da primeira, baseiam-se no conceito subjacente de "autoconsciência feminina" que emerge na literatura a cada período analisado, no sentido de estabelecer um vocabulário crítico e acurado e uma história literária sistemática das mulheres escritoras capaz de reconstruir a experiência política, social e cultural das mulheres.

${ }^{31}$ COELHO, Nelly N. Tendências atuais da literatura feminina no Brasil. In: COELHO, Nelly N. et al. (orgs.) Feminino Singular - A participação da mulher na literatura brasileira contemporânea. São Paulo: GRD; Rio Claro, SP: Arquivo Municipal, 1989, p.6.
} 
figura feminina, em que algumas escritoras buscam um novo conhecimento de mundo associado à busca de si mesmas, enquanto outras demonstram um crescimento da consciência de que o 'problema da mulher' só seria solucionado quando os limites tradicionais fossem ultrapassados, quando a mulher pudesse se "projetar como ser humano, para além do círculo amoroso homem/mulher(...) $)^{, 32}$. O terceiro momento de conscientização apresenta a superação, na literatura feita por mulheres, da imagem tradicional da mulher, ligada à domesticidade; o amor deixa de ser tema dominante para abrir as portas às sondagens existenciais, às fantasias intertextuais, ao erotismo, à redescoberta dos mitos e à "consciência da Palavra como agente criador do Real”33, características temáticas também presentes nos romances e contos publicados por Lygia a partir da década de 70 e mais acentuadamente na de 80. Cabe ressaltar, no entanto, que essa divisão em 'momentos' ou fases, no que concerne à escrita feita por mulheres, está adequada à percepção de características predominantes em diferentes momentos em que as mulheres passam a escrever, o que não significa que estão excluídas da obra de uma determinada autora características de momentos anteriores ou posteriores, como é o caso de Lygia F. Telles.

É interessante verificar a proposta sugerida por Lucia Helena Vianna de um viés crítico de leitura de textos escritos por mulheres, baseado na importância da memória, isto é, sua forma de apresentação e as estratégias pelas quais contribui para a construção do que a pesquisadora intitula "poética feminista” na literatura feita por mulheres no Brasil:

(...) toda discursividade produzida pelo sujeito feminino que, assumidamente ou não, contribua para o desenvolvimento e a manifestação da consciência feminista, consciência esta que é sem dúvida de natureza política $(O$ pessoal é político), já que consigna para as mulheres a possibilidade de construir um conhecimento sobre si mesmas e sobre os outros, conhecimento de sua subjetividade, voltada esta para o compromisso estabelecido com a linguagem em relação ao papel afirmativo do gênero feminino em suas intervenções no mundo público. Consciência com relação aos mecanismos culturais de unificação, de estereotipia e exclusão. E ainda, a consciência sobre a necessidade de participar conjuntamente com as demais formas de gênero (classe, sexo, raça) dos processos de construção de uma nova ordem que inclua a todos os diferentes, sem exclusões. Poética feminista é poética empenhada, é discurso interessado. É política. ${ }^{34}$

\footnotetext{
${ }^{32}$ COELHO, Nelly N. Tendências atuais da literatura feminina no Brasil. In: COELHO, Nelly N. et al. Feminino Singular - A participação da mulher na literatura brasileira contemporânea.Op.cit., p. 9.

${ }^{33}$ Ibid., p. 10.

${ }^{34}$ VIANNA, Lúcia H. Poética feminista- poética da memória. In: Labrys- estudos feministas, n.4, ago - dez. 2003. Disponível em: < http://www.unb.br/ih/his/gefem/labrys4/textos/lucia1.htm> Acesso em: 25 jun. 2008.
} 
Considerando a definição de 'poética feminista' de Vianna, no que concerne à possibilidade de a mulher escritora "construir um conhecimento de sua subjetividade" e de "sua consciência com relação aos mecanismos culturais de unificação, de estereotipia e exclusão" no exercício da criação literária, a memória, como aquela que permite uma espécie de recuperação da experiência, espelha, na prosa de Lygia Fagundes Telles, a partir de Rosa, mas também de Rahul, o próprio fazer literário da escritora. Sua 'poética' se configura, em sua mais recente produção ${ }^{35}$, reveladora da preocupação de Lygia como escritora, em seus romances, com a representação da experiência da mulher localizada historicamente, em especial a de classe média, que também é a sua, pelo caminho da rememoração. No âmbito da literatura, evidentemente, a condição de mulher e a experiência da escritora não determinam, pura e simplesmente, a existência de um texto literário crítico sobre a questão dos gêneros, mas em As Horas Nuas, como em muitos outros textos literários escritos por mulheres, invenção, experiência e memória remetem a um jogo paradoxal que problematiza essa questão, na medida em que a experiência pessoal e a social estão fortemente entrelaçadas. Se o pessoal é político, como preconiza a crítica feminista, a experiência da mulher está articulada, literariamente, com a representação da dinâmica das relações de poder com as quais as personagens femininas travam embates, sejam eles em nível familiar, social ou até mesmo cultural; nesse sentido, a autora assume "sua posição de mulher nos processos de alteridade"36 . Ao construir uma personagem que se volta em direção ao passado - não só ao gravar suas memórias, mas especialmente ao longo do romance como um todo-, Lygia, como escritora, utiliza-se dos mecanismos da memória - a lembrança, o esquecimento e a imaginação - à luz do presente, para elaborar uma nova relação da protagonista com esse passado, na medida em que esta aciona também memórias de outros e outras, sociais e coletivas- principalmente as figuras femininas familiares nas quais a protagonista também se espelha. Para a compreensão de As Horas Nuas sob esse viés, portanto, é fundamental o estabelecimento do que Vianna denomina "pacto memorialístico", isto é, de uma leitura do romance como texto ficcional no qual existem "resíduos de uma memória individual e cultural, que não deixam de se apresentar como 'fantasmas' reveladores do mundo íntimo do

\footnotetext{
${ }^{35}$ Cabe ressaltar que os limites entre realidade e ficção têm sido uma preocupação da escritora, como a publicação do livro de fragmentos A disciplina do amor (1980), seguido de Invenção e Memória (1998) e Conspiração de nuvens (2007) pode demonstrar. Nesses textos, os resíduos da memória recebem tratamento ficcional, oscilando entre verdade e invenção.

${ }^{36}$ TEIXEIRA, Níncia C. R. B. Letras femininas: a escrita do 'eu' no universo de Luci Collin. In: Revista Brasileira de Literatura Comparada, n. 12, 2008, p. 331.
} 
indivíduo e, em especial, das mulheres" ${ }^{\natural 7}$. Nesse sentido, do texto para o leitor, sob o signo da ironia, revela-se a importância da atuação de Rosa Ambrósio como mulher no mundo público e as consequências no tocante ao mundo privado.

Em entrevista concedida ao programa Roda Viva, da TV Cultura, em outubro de 1996, Lygia comenta, entre outros assuntos, as discriminações sofridas quando começou a escrever justamente por ser mulher. Recorda-se de uma crítica feita ao seu livro de contos Praia Viva:

(...) essa discriminação fez que quando eu publicasse o livro ficasse felicíssima, porque um cronista escreveu o seguinte: "Esta menina é estranha. Ela escreve feito um homem, feito um homem barbado." Eu fiquei na maior felicidade. Porque esse era o maior elogio, escrever como um homem, está compreendendo? Porque a mulher, as meninas, as moças que escreviam na época - pois é, até parece que eu estou falando da Idade Média - eram discriminadas. Era considerado (sic!) uma literatura separada, assim como aquele poço separando a literatura masculina, que era sempre muito superior e tal, da literatura feita pelas moças. ${ }^{38}$

Nessa época, portanto, a mulher que escrevia bem era aquela que escrevia feito homem ${ }^{39}$ - afirmação que se deve certamente ao fato de a escritora ter se aventurado num gênero canônico - leia-se, masculino - como o conto, dominando temas e linguagens que se distanciavam daqueles normalmente utilizados em subgêneros tidos como menores e comumente associados e/ou permitidos à mulher, como os diários e as cartas. Nelly N. Coelho argumenta que os contos de Praia Viva “já são alimentados pela problemática que se mostrará nuclear na obra da autora: o desencontro entre o eu e o mundo, entre a aparência do real e sua

\footnotetext{
${ }^{37}$ VIANNA, Lúcia H. Poética feminista- poética da memória. Op.cit.. A crítica faz referência explícita ao pacto fantasmático de Philippe Lejeune, que se propõe a discutir a teoria segundo a qual o romance seria mais verdadeiro do que a autobiografia e que encontra em Gide e Mauriac grandes defensores dessa tese, os quais consideram suas tentativas de escrever autobiografias fracassadas, uma vez que sua 'verdade' poderia ser encontrada em seus romances. Para o crítico francês, longe de ser uma condenação à autobiografia, os comentários dos referidos escritores estabelecem qual ordem é a verdade última a que visam seus textos, isto é, "enquanto autobiografia que se decretou ser o romance mais verdadeiro" (p.42). Desse modo, o leitor seria convidado a realizar uma leitura de romances não apenas como ficções que remetam a uma verdade da natureza humana, mas como fantasmas capazes de revelar um indivíduo. A esse contrato de leitura, Lejeune denomina pacto fantasmático, uma forma indireta de pacto autobiográfico, no qual é premente a identidade autor, narrador e personagem. In: LEJEUNE, Philippe. O pacto autobiográfico. In: LEJEUNE, Philippe; NORONHA, Jovita M. G. (org.) O pacto autobiográfico- de Rousseau a Internet. Tradução Jovita M. G. Noronha, Maria Inês Coimbra Guedes. Belo Horizonte: Editora UFMG, 2008.

38 Memória Roda Viva. Entrevista com Lygia Fagundes Telles. 07 out. 1996. Disponível em: $<$ http:www.rodaviva.fapesp.br/materia/101/entrevistados/lygia_fagundes_telles_1996.htm> Acesso em: 18 nov. 2008.

${ }^{39}$ Rachel de Queiroz também ganhou reconhecimento por parte da crítica, quando se lança à carreira de escritora, por apresentar como atributo uma 'personalidade viril', como analisa Nádia Batella Gotlib a partir do comentário feito pelo crítico Olívio Montenegro sobre a escritora cearense, em A literatura feita por mulheres no Brasil. In: BRANDÃO, Izabel e MUZART, Zahidé. Refazendo nós. Florianópolis: Editora Mulheres; Santa Cruz do Sul: EDUNISC, 2003, p. 47.
} 
verdade oculta; a hipocrisia social; o drama da rejeição que engendra seres acossados pelo medo e pela solidão sem saída..."40, temas também de dimensão universal, tratados por grandes escritores como Machado de Assis e William Faulkner, por exemplo, e que possivelmente contribuíram para a apreciação crítica do livro de Lygia sob o prisma de uma 'escrita masculina'. Pela leitura de alguns contos de Praia Viva, como em "Táxi, cavalheiro?"41, por exemplo, percebe-se, no entanto, que Lygia, implícita no protagonista Cristóvão, traz à tona preconceitos enraizados contra a mulher, como a de que esta pertence a uma 'raça miserável', a qual deveria sofrer coerções ao desejo de satisfazer suas próprias vontades, para que o 'brio' masculino não sofresse nenhum 'arranhão'. O leitor que conhece sua obra posterior, no entanto, fica surpreso com a reprodução do discurso masculino vigente e parece vir daí também o 'elogio' feito pelo crítico quanto ao 'sexo' de sua escrita; no entanto, de uma leitura realizada nos dias de hoje advém o tom irônico que, embora confirme, por um lado, que a escritora escreve como 'homem', por outro, revela a subversão de Lygia como mulher à ordem patriarcal, tida como 'natural'. Nos planos pessoal e profissional, ela se lança como escritora, é uma das primeiras mulheres a ingressar na Faculdade de Direito do Largo São Francisco, a escolher uma profissão considerada masculina por excelência na década de 1940 e a trabalhar como funcionária pública no cargo de Consultor Jurídico. Anos mais tarde, a escritora afirma:

Sou escritora e sou mulher - ofício e condição duplamente difícil de contornar, principalmente quando me lembro como o país (a mentalidade brasileira) interferiu negativamente no meu processo de crescimento como profissional. Eu era reprimida, tímida em meio à imensa carga de convenções cristalizadas na época. Penso que minha libertação foi facilitada durante as extraordinárias alterações pelas quais passou o Brasil desde minha adolescência até os dias atuais. ${ }^{42}$

Em outro trecho da entrevista à TV Cultura, Lygia atribui àquela 'literatura íntima', composta justamente por diários, cartas, anotações em 'cadernos do dia-a-dia', os primeiros passos do que mais tarde tomaria corpo como uma literatura na qual a mulher escritora tenta constantemente 'desembrulhar-se' para compreender-se/conhecer-se a si própria:

Isso vem da tradição da mulher, (...) justamente a tradição da mulher que começou a escrever, as minhas tiazinhas, aquelas tias lá de longe que

\footnotetext{
${ }^{40}$ COELHO, Nelly N. Dicionário crítico de escritoras brasileiras - 1711 a 2001. São Paulo: Escrituras Editora, 2002, p. 387.

${ }^{41}$ FAGUNDES, Lígia. Praia viva. São Paulo: Livraria Martins Editora, 1944.

42 TELLES, Lygia F. A criação literária - no princípio era o medo. Op.cit..
} 
escreviam, começaram a escrever os seus poemas, as suas tias, avós, bisavós, naqueles cadernos do dia-a-dia, onde elas punham o preço da cebola, da batata e de vez em quando vinha um pensamento. A mamãe, a minha mãe mesmo, tinha um livro, um diário, onde ela escrevia os seus pensamentos e um dia ela disse: "Sabe filha, você sabe que não é bonito uma mulher casada...", olha minha mãe hein!, (...) "Não é bonito uma mulher casada começar escrever coisas, pensamentos, devaneios, porque eu me lembro que o papai dizia que mulher casada quando começa a escrever essas coisas só pode ser bandalheira" (...) mulher casada não tem que escrever nada de suas confissões. Isso fica para as mocinhas e seus diários. Então, (...) eu vejo nesses diários de capas acetinadas com pombinhas, coraçõezinhos pintados, o início justamente dessa literatura intimista e subjetiva. (...) Seria a fonte primária das mulheres tentando se dizer, tentando se explicar, tentando se desembrulhar. (...) A mulher é mais embrulhada do que o homem porque ela foi obrigada a ser embrulhada. Eu não preciso lembrar vocês que a mulher passou, no Brasil, dentro do espartilho lusitano, a mulher passou um tempo enorme calada. Ela não tinha o direito à palavra, ela não tinha o direito às $\operatorname{artes}(\ldots){ }^{43}$

O comentário de Lygia corrobora, portanto, a visão de escritura como um processo de autorreflexão e descobrimento, especialmente no que tange à ligação que a escritora paulistana estabelece entre a qualidade confessional da literatura feita por mulheres, com um certo componente autobiográfico, com o silêncio imposto à mulher por longos tempos. ${ }^{44}$ Apoiada nesses pressupostos, minha leitura 'ginocrítica' ${ }^{45}$ dos romances publicados por Lygia Fagundes Telles, permite, por esse viés, verificar, em Ciranda de Pedra (1954), Verão no Aquário (1963), As Meninas (1973) e, especialmente em As Horas Nuas (1989), foco deste trabalho, um forte engajamento social da escritora, na medida em que esses textos dizem "respeito à mulher e expressam a realidade de um ponto de vista da mulher e em função daquilo que ela vivencia" 46 , de acordo com o momento em que seus romances foram escritos e publicados, o que não exclui, obviamente, o contraponto elaborado pela escritora na representação de figuras masculinas, mas inclui os caminhos por ela utilizados para transpor sua autoconsciência de mulher na forma literária.

\footnotetext{
${ }^{43}$ Memória Roda Viva. Entrevista com Lygia Fagundes Telles. Op.cit..

${ }^{44}$ PINTO, Cristina F. O bildungsroman feminino- quatro exemplos brasileiros. São Paulo: Perspectiva, 1992, p. 122.

${ }^{45}$ Faço aqui um uso adjetivado do substantivo cunhado por Elaine Showalter, ginocrítica, para me referir, como preconiza a autora americana, a um 'discurso crítico especializado' que corresponde à mudança de enfoque das leituras revisionistas da literatura feita por mulheres para "o estudo da mulher como escritora”, cujos tópicos são "a história, os estilos, os temas, os gêneros e as estruturas dos escritos de mulheres; a psicodinâmica da criatividade feminina; a trajetória da carreira individual ou coletiva; e a evolução e as leis de uma tradição literária de mulheres." SHOWALTER, Elaine. A crítica feminista no território selvagem. In: HOLLANDA, Heloísa B. (org.) Tendências e impasses. Op.cit., p. 29.

${ }^{46}$ PINTO, Cristina F. O bildungsroman feminino. Op.cit., p. 25.
} 
Antonio Candido ensina que uma crítica integradora é aquela "capaz de mostrar (...) de que maneira a narrativa se constitui a partir de materiais não literários, manipulados a fim de se tornarem aspectos de uma organização estética regida pelas suas próprias leis, não as da natureza, da sociedade ou do ser" ${ }^{, 47}$. As questões do teatro, da memória e da experiência norteiam este trabalho no que se refere à representação do mundo, à representação como mediação e ao fazer estético, ao trabalho artístico presente no último romance de Lygia Fagundes Telles, não apenas como temas literários, mas sobretudo como elementos estruturantes da condição da mulher sob a ótica feminina. Não basta, apenas, ler as produções, silenciadas ou não, de mulheres ou de outras minorias - em que, atualmente, a obra de Lygia, hoje reconhecida nacional e internacionalmente, já não se enquadra-, mas sim, realizar uma interpretação que permita avaliar o romance em seu plano formal, ponto de partida para a análise. Mesmo diante das dificuldades de se fazer uma crítica que se queira integradora, procurarei revelar que a construção da protagonista feminina Rosa Ambrósio está intimamente ligada à sua posição social e ao seu relacionamento com as demais personagens do romance, permitindo recuperar sua experiência social como mãe, esposa, amante, patroa e atriz. A protagonista enfrenta um processo de reflexão que a faz buscar em suas origens as respostas necessárias para preencher as lacunas incompreensíveis para as situações de conflito oriundas das relações pessoais e sociais no presente da narrativa. Com isso, no trânsito entre as esferas pública e privada, sua história e a de outras personagens femininas de As Horas Nuas se misturam à das mulheres na sociedade brasileira do final dos anos 80 , em contrapartida com as de outros tempos.

Desse modo, as análises que se seguem são uma tentativa de responder como os mecanismos de mediação escolhidos pela autora, em especial as peças de teatro e a escrita das memórias, participam da manutenção do jogo da representação em torno do foco central do romance, contracenando com seus espelhos e despindo-se de suas máscaras, numa intensa dialética de exposição e ocultamento, reveladora da experiência feminina expressa literariamente.

\footnotetext{
${ }^{47}$ ANTONIO Candido. Prefácio. In: O Discurso e a Cidade. 3. ed. Duas Cidades/ Ouro sobre Azul: São Paulo/Rio de Janeiro, 2004, p.9.
} 
Chulher ao Espelho

*ojje, que seja esta ou aquela, pouco me importa. Quero apenas parecer bela, pois, seja qual for, estou morta. Sá fui loura, jấ fui morena, Sáfui Charganida e Deatriz, Sáfui Charia e Cradalena. Qsó não pude ser como quis. Que mal fare, esta cor fingida do meu cabelo, e do meu rosto, se tudo é tinta: o mundo, a vida, o contentamento, o desgosto? Dor fora, serei como queira, a moda, que vai me matando.

Que me levem pele e caveira ao nada, nãa me importa quando. Cras quem viu, tão dilacerados, olhos, bracos e sonhos seus, e morreu pelos seus pecados, fálará com Đous. Ofalará, cobenta de luzes, do alto penteado ao rubro artelho. Dorque uns expiram sobre cruzes, outros, buscando-se no espelho. 


\section{TEATRO E REPRESENTAÇÃO: UMA QUESTÃO DE PONTO DE VISTA}

El hombre es lo menos possible él mismo cuando habla en persona. Déle usted un antifaz, y dirá la verdad. ${ }^{48}$

Oygia Fagundes Telles optou pelo teatro como a grande metáfora da
representação em As Horas Nuas. A escolha da carreira profissional de sua protagonista já torna essa afirmação evidente na superfície do texto- Rosa Ambrósio é uma atriz, aquela cuja função é fundir-se com as personagens que encena, é identificar-se com um outro $\mathrm{eu}^{49}$. A metamorfose do ator, transformado em personagem, é simbolizada pela máscara, que, por sua vez, remete a Dioniso, o deus grego. A origem da tragédia - em grego, 'canto do bode' -, está relacionada com os solistas do ditirambo - uma espécie de hino religioso, cantado por um coro em honra de Dioniso, após o sacrifício de um bode, forma na qual ele por vezes se manifestava - e teria se desenvolvido mediante o processo de transformação das peças satíricas, em que as personagens que compunham o coro se disfarçavam em Sátiros, os companheiros de Dioniso. Os devotos do deus caíam semidesfalecidos depois de ingerirem vinho e dançarem vertiginosamente, saíam de si pelo processo de êxtase, o que implicava "um mergulho de Dioniso em seu adorador", por meio do entusiasmo. Desse modo, o homem, “comungando com a imortalidade”, tornava-se um herói que ultrapassava seu métron, sua medida mortal e, assim o fazendo, transformava-se em hypocrites, "aquele que responde com êxtase e entusiasmo, a saber, o ator" ${ }^{\text {", }}$, aquele que é capaz de identificar-se com o outro no exercício do esquecimento de si mesmo momentâneo da atividade teatral, representando-o simbolicamente.

$\mathrm{Na}$ tentativa de encenar Rosa Ambrósio por si mesma, a atriz revela para o leitor o próprio martírio: "Fiquei sozinha para me executar, sou meu carrasco. Pior do que um

\footnotetext{
48 “O Homem quase nada diz quando fala em seu nome. Dêem-lhe uma máscara e ele lhe dirá a verdade". WILDE, Oscar. El critico artista- parte II. In: Obras completas. Tradução Julio Gomez de la Serna. Madrid: Aguilar, 1958, p. 952.

${ }^{49}$ ROSENFELD, Anatol. A essência do teatro. In: Prismas do teatro. São Paulo: Perspectiva: Editora da USP; Campinas, Ed. Da UNICAMP, 1993, p. 21.

${ }^{50}$ BRANDÃO, Junito de Souza. Mitologia Grega. v.2. 4 ed. Petrópolis: Vozes, 1991, p.132.Com o tempo, a tragédia passou a buscar seus temas em outros mitos heróicos e, assim, perdeu muito de seu caráter dionisíaco, embora se reconheça nesse deus "uma das forças vivas que impulsionaram o desenvolvimento do drama trágico como obra de arte"(p. 129). Daí a associação que se faz do culto a Dioniso com o nascimento do teatro.
} 
estranho porque já me amei, pum! disparo no coração do coração. Caio redondamente morta" $(\mathrm{HN}, \text { p. 48 })^{51}$. Como vítima e algoz de si mesma, usa como armas a lembrança e o esquecimento, a fim de compreender sua responsabilidade pela situação 'trágica' em que se encontra. Nesse estado limite, a velha atriz precisa empreender incursões ao universo do passado, através da bebida, para preencher o vazio e a falta de interesse por sua vida presente e tentar buscar, nos momentos ociosos, o sentido perdido. Bebe, então, "em homenagem a la busca" (HN, p. 12), perpassando necessariamente as fraquezas dos diversos papéis que desempenhara fora do teatro, pela via do remorso: “Atriz medíocre, mãe egoísta, amante infiel e dona-de-casa descuidada" (HN, p. 103). Nos momentos em que a vaidade falava mais alto, apregoava que ao teatro dera o melhor de si e que, talvez, tenha representado melhor do que vivera.

A propósito, o verbo representar, além do significado trivial do termo, usado no teatro, cinema ou televisão como sinônimo de interpretar uma personagem, encenar, desempenhar papel ou qualidade de outro, carrega também, segundo o dicionário Houaiss, outros sentidos: ser a imagem ou a reprodução de algo, figurar como símbolo, presumir. No sentido de reproduzir algo existente é que o termo se encontra ligado à acepção fundamental que adquire no âmbito dos estudos de literatura. Como sabemos, as reflexões sobre a natureza da obra literária encontram nos trabalhos de Platão e Aristóteles as primeiras concepções de caráter filosófico, bases para as discussões teóricas posteriores de estudiosos do assunto que procuraram compreender e conceituar o que é a literatura, passando pela tentativa de definição e enquadramento dos gêneros literários e as diversas acepções recebidas no Renascimento, passando pelo Romantismo até chegar às concepções mais contemporâneas. Na concepção daquele último filósofo grego, o artista deveria supor uma visão do real e certo modo de imitá-la, de transformá-la, que teria o mundo, isto é, algo preexistente, como ponto de partida. Trata-se, na tradição aristotélica, de imitação como "representação criativa", manifestada, no caso do romance, na "urdidura da ação, concebida como organização ficcional dos sentimentos e dos pontos de vista narrativos, para formar o que se chamaria depois uma estrutura" ${ }^{, 52}$. A tentativa de fixar as características da tragédia, da comédia, do poema lírico e do épico, como gêneros puros, passava necessariamente pela questão da imitação e conviveu com o surgimento de novas formas de narrar, em contextos histórico-

\footnotetext{
${ }^{51}$ TELLES, Lygia F. As Horas Nuas. 4.ed. Rio de Janeiro: Rocco, 1999. Neste trabalho, a sigla HN substituirá o título do romance As Horas Nuas, de Lygia Fagundes Telles, cuja edição é citada anteriormente, seguida do número de página.

${ }^{52}$ Antonio CANDIDO. O patriarca. In: A educação pela noite e outros ensaios. 3. ed. São Paulo, Ática, 2000 , p. 76.
} 
culturais específicos, como o romance. Quando este gênero se consolida no século XIX, o realismo se afirma como "postura e método", isto é, envolvia, respectivamente, "ideologias, mentalidades, sentido histórico", e "personagens, objetos, ações e situações descritos de modo real, isto é, de 'acordo com a realidade"" 53 . Com o seu desenvolvimento emergiram, também, as dificuldades de encerrá-lo dentro de gavetas, com etiquetas 'apropriadas', devido à sua flexibilidade, como diversos teóricos e historiadores da literatura têm procurado demonstrar.

Salvo suas especificidades em contextos distintos, no romance a posição adotada pelo escritor diante da realidade a ser representada estava intimamente ligada à crença na razão iluminista, em que o ponto de vista centralizador de um narrador onisciente era capaz de projetar o mundo exterior, analisando, interpretando e, desse modo, 'representando' a personagem. Como se sabe, com o avanço de novas formas de tecnologia como a fotografia, o cinema e o telefone, com o desenvolvimento da Psicanálise e dos estudos sobre o inconsciente, novidades aliadas à desilusão que a idéia de progresso causara, diante dos cataclismas do início do século XX, o escritor se dá conta da necessidade de outros modos de perceber e representar a realidade, que incluem o mergulho na consciência humana, agora tida também como representável e parte do real. Instaura-se, a partir de então, o que a crítica tem chamado de 'crise da representação', esta última limitada ao conceito de realidade como algo exterior ao indivíduo. Essa nova percepção do escritor se revela no romance moderno com o uso da colagem e da montagem, com o desmascaramento das categorias de espaço, tempo e do princípio de causalidade como aparências exteriores. Desse modo, o subjetivismo entra em cena e derruba, como afirma Adorno, o "mandamento épico da objectualidade" ${ }^{\text {" }}$ e, em função disso, a cronologia é abolida em favor do tempo interior das personagens que, muitas vezes, corresponde ao tempo da memória e do imaginário, como é o caso da produção ficcional de Telles.

No século passado, diversos teóricos retomaram os pressupostos aristotélicos acerca da literatura, para ressaltá-los ou superá-los, principalmente quando o assunto perpassa a própria natureza do conceito: a questão da representação - da mimesis, traduzida também por imitação - e o efeito mesmo dessa representação - a distinção, clássica, entre verdade e verossimilhança. Essas discussões, obviamente, são muito mais profundas e não se resumem

${ }^{53}$ PELLEGRINI, Tânia. Realismo: postura e método. Letras de Hoje. Porto Alegre, v. 42, n.4, dez. 2007, p. 139.

${ }^{54}$ ADORNO, Theodor W. Posição do narrador no romance contemporâneo. In: BENJAMIN, Walter; HORKHEIMER, Max; ADORNO, Theodor W.; HABERMAS, Jurgen. Textos escolhidos. Tradução José Lino Grunnewald et al.. 2.ed. São Paulo: Abril Cultural, 1983, p. 269. (Os pensadores) 
apenas às noções de imitação/representação, verossimilhança; envolvem reflexões de cunho filosófico e cultural e seus antagonismos, além das diversas maneiras que a crítica especializada tem tratado o problema, o qual passa, no caso da ficção em prosa, pela questão da mediação e das formas de narrar. Se a literatura e as artes assistiram à guinada no conceito de representação, ao aparente abandono da 'referencialidade' e às reviravoltas no que tange à noção de experiência, como uma cultura pós-moderna poderia facilmente convencer, por outro lado, uma visão também pós-moderna aponta para o surgimento de novas representações, como as que se desvinculam daquelas tidas como centrais, ocidentais, masculinas, brancas e de classe privilegiada. Basta lembrar da emergência dos movimentos das minorias nas décadas de 60 e 70- gays, lésbicas, mulheres, negros - um dos mais significativos traços pós-modernos -, e dos posicionamentos adotados por teóricos póscoloniais, no âmbito da cultura, da literatura e das artes. As questões surgidas a partir de então problematizam as relações entre o universal e o particular no que tange às discussões sobre centro e periferia, nação, diásporas e fim ou permanência das utopias. Diante desse novo 'caldo de cultura', é necessário refutar, no entanto, as generalizações e observar com atenção a insistente permanência de vozes que, em meio ao caos, realizam uma literatura de alto valor artístico, que, ao fugir aos clichês, constituem uma espécie de resistência às tão apregoadas crises contemporâneas da história e da narrativa.

Pelos motivos expostos, a metáfora da revelação paradoxal da arte, que a partir do conceito de máscara descortina 'segredos recônditos' do ser humano, sugerida na epígrafe de Oscar Wilde que abre esse capítulo, encontra eco nos conceitos de representação que pretendo analisar em As Horas Nuas. Para este trabalho, as preocupações teóricas com as maneiras de representar encontram-se ligadas justamente à representação como mediação, calcadas na intertextualidade a partir de referências teatrais, no subgênero das memórias e nos pontos de vista narrativos adotados no romance, e aos diversos papéis sociais vividos pela protagonista com relação às personagens com as quais ela contracena ${ }^{55}$. Numa visão global, pode-se dizer, ainda, que se referem ao projeto literário de Lygia Fagundes Telles como escritora.

\footnotetext{
${ }^{55}$ Neste capítulo, a discussão focalizará a representação como mediação a partir da intertextualidade com as peças que ajudam a compor a protagonista Rosa Ambrósio e das técnicas utilizadas pela escritora na construção do romance como um todo. As demais peças teatrais, que envolvem a construção do relacionamento da protagonista com as personagens masculinas, e as outras questões propostas serão discutidas oportunamente nos capítulos que se seguem.
} 


\title{
2.1. Rosa Ambrósio: vestida de máscaras
}

\begin{abstract}
Por que não pisava com os dois pés no presente? Um maldito pé nostálgico ficava no passado enquanto outro pé, o da ambição, se perdia no futuro, o demônio da cobiça me empurrando, vai! Vai! (...) Só no palco, não é estranho? sempre fui inteira. Sem evasão da vontade, como diria a analista. Essa Ananta. É porque você sabe que só o grande artista aceita levar apenas um copo d'água, disse o Diogo. A soberba tem dessas ciladas, garota. Pode ser. Mas quero deixar bem claro que nunca fugi em cena, as fugas foram aqui fora. Representei então melhor do que vivi? Nem isso.

- Por que não começa agora a vida que te resta? pergunto em voz alta. Estou dividida: sou o sargento enfurecido que interpela o recruta que quer dar baixa. Sem honra. Em posição de seeentido! e fazendo nas calças. O outro fazendo também porque não tem moral para se impor ao subordinado. Mas precisa ser arrogante. Exigente. O recruta se apruma, heróico, já prometeu outras vezes, quer reagir, lutar! Amanhã mesmo me entrego à mais feroz limpeza por fora e por dentro, por acaso não sou livre? Hem?! As rédeas do meu destino não estão nas minhas mãos?, pergunto retumbante e o sargento se cala porque nas minhas mãos ele está vendo outra coisa. (HN, p. 159-160)
\end{abstract}

A passagem que dá início a essa reflexão é um pequeno fragmento do processo de busca de identidade, a partir das recordações, repletas de culpa e remorso, de Rosa Ambrósio. A grande atriz desceu do pedestal, do palco onde encenara tragédias e dramas, e encontra-se como uma "abelha tonta resvalando para o chão macio" (HN, p. 47), como gostava de dizer. Está dividida. À simples pergunta, não consegue dar uma resposta à altura: “- Por que não começa agora a vida que te resta?". Na tentativa de responder, desdobra-se em narradora: ela é capaz de analisar e interpretar ${ }^{56}$, representada metaforicamente no sargento e em seu recruta. Isso sugere seu conflito interior: ouvir a própria voz de comando e cumprir o que lhe foi confiado. Seguro, arrogante e exigente, o comando dá a ordem a ser cumprida - recomeçar a vida. A faceta que se subordina à ordem necessita da coragem, do sentido da luta para desempenhar a função; invadida pela certeza da mudança, crendo na voz comandante, apruma-se e, heróica, afirma que sua limpeza interna e externa ocorrerá no dia seguinte. A força repentina faz perceber o poder que deve estar em suas mãos - as rédeas do destino; mas

\footnotetext{
${ }^{56}$ A idéia de desdobramento de Rosa em narradora também é compartilhada por Liem Hani Alcântara, com base no estudo de Maria Lucia dal Farra, que considera como razão de tal desdobramento a complexidade da personagem Rosa Ambrósio, a qual reside na sua "capacidade de encerrar diferentes aspectos de visão, ou melhor, na aptidão que lhe confere o autor implícito de olhar e se olhar". ALCÂNTARA, Liem Hani. Palavra: rota de salvação em Xerazade e os Outros e As Horas Nuas. Tese (Doutorado em Estudos Comparados de Literaturas de Língua Portuguesa). Faculdade de Filosofia, Letras e Ciências Humanas, Universidade de São Paulo. São Paulo, 2007, p. 157. Na minha perspectiva, porém, as diferentes focalizações narrativas - a saber, Rahul e o discurso indireto livre de Ananta - é que exercem o papel mais amplo de circunscrição de Rosa, permitindo que se mostre a impossibilidade mesmo de enquadramento de 'quem conta a história' em categorias rígidas e preestabelecidas em As Horas Nuas.
} 
o desejo de comandar a própria vida faz ver, no lugar do presente, que projeta o futuro, outra coisa que não a coragem: o medo.

Um medo proveniente da atávica necessidade de viver com um pé fincado no passado, com tudo o que ele representa - a juventude, a família, a fé, o primeiro amor, a vida cotidiana menos atribulada - e outro, na ambição, com o desejo insaciável de acumular bens, jóias, apartamentos, homens, fama e, assim, projetar-se para o futuro, acompanhando a tendência de uma cultura para as massas que se inicia em escala menos avassaladora, com os ditames do cinema hollywoodiano e das revistas femininas de moda e comportamento, passando pela influência da televisão e do desenvolvimento de novas formas de produção e consumo. Desse modo, um traço extra-literário, configurador da vida cultural burguesa no Brasil até a década de 1960 , mote do projeto de modernização que visava à construção da identidade nacional ${ }^{57}$ a necessidade de se reconhecer como membro da elite 'civilizada', a fim de justificar sua aproximação com a 'modernidade' representada pelas classes sociais abastadas do capitalismo central - transforma-se, no modo como afetou as relações familiares, no elemento que acompanha, sob a tensão entre exposição e ocultamento, a dialética do pessoal e do coletivo em Rosa, como veremos.

No hiato entre o ontem e o amanhã, a realidade: as glórias do teatro, as viagens inesquecíveis, as festas, por um lado; por outro, a velhice, a solidão, o marido Gregório, a filha Cordélia, família infeliz, relegada a um plano inferior, substituída pela atriz sempre em busca do que não tinha. O presente constantemente adiado: Gregório não era o primeiro amor, procurado em outros homens; Cordélia não tinha ambição, boiava "no rio do supérfluo" e gostava de homens velhos, na maioria pobres, o oposto ansiado pela mãe. A tensão entre passado e ambição, nostalgia e acúmulo, que norteara a vida de Rosa, só é abalada quando o corpo começa a dar sinais de seu 'amadurecimento'; a vaidade é grande demais para expor seu corpo em decadência sob a luz dos holofotes. Sem ocupação e solitária, tem o tempo necessário para perceber a dissolução de seu núcleo familiar, amoroso e profissional. Todos foram embora: viajaram, morreram ou foram ordenados a se retirar. A juventude passa o bastão à velhice; já não é preciso acumular mais bens: tem fama, dinheiro, propriedades. Para Rosa Ambrósio, não há outra escolha: precisa pisar com os dois pés no presente e encarar o lado negro do espelho, mas tem medo da luz. Embora o sol esteja 'sempre em seu rastro',

\footnotetext{
57 Ortiz, Renato. A moderna tradição brasileira. São Paulo: Brasiliense, 1999. Esse projeto tem suas origens no século XIX, com a emergência da República, quando as intenções de modernização da capital do país por parte do novo regime trazem a reboque as ideias de europeização e civilização, marcando a passagem das relações senhoriais às relações do tipo burguês.
} 
considera-o seu inimigo e, por isso, prefere a escuridão e a solidão do quarto, onde bebe, dorme, chora, monologa ou representa para um público agora restrito, formado apenas pela empregada negra e por seu gato. O estado alterado de percepção, provocado pelo consumo de vinho e de uísque, permite uma radicalização de seu monólogo, em que a censura ao que pode ou não ser dito é preterida no processo de embriaguez, e a insistência no medo do envelhecimento, no remorso e a repetição recorrente das lembranças é contundente. "Não guardarei senão as horas felizes, estava escrito no relógio-do-sol. As coisas boas, as coisas lindas. Estou repetindo muito, Diú?” (HN, p. 118). A constante associação de idéias sugere também que nenhuma lembrança consegue sustentar-se por muito tempo expressa em frases longas, "como se o próprio ritmo discursivo sofresse seus sobressaltos, figurativizando a descontinuidade do trabalho da memória ao resgatar uma matéria difícil de ser digerida" ${ }^{„ 58}$. A repetição de idéias, frases e sonhos configura-se, portanto, como uma maneira de preservar as 'horas felizes' e tentar chegar ao âmago de seu drama pessoal e solucionar o conflito, que se formaliza numa linguagem com o predomínio de frases curtas, em que vicejam substantivos, capazes de nomear a dor e a falta, em detrimento de uma adjetivação prolixa e de verbos em abundância, já que são poucas as ações da protagonista na narrativa.

Mais uma vez, como em outras narrativas de Telles, o espaço doméstico, metonimicamente representado pelo quarto, tem um valor de redoma, de concha, pois é nele que Rosa se refugia do mundo exterior, preferindo desligar a TV ou deixar de ler jornais, nos quais ela já não figura e que trazem para o interior da casa a deterioração da qualidade de vida urbana numa metrópole como São Paulo. Essa característica de Rosa Ambrósio é comum a outras personagens de Telles, a qual “(...) insiste no caráter do distanciamento psicoespacial como protetor contra as misérias da existência que, vistas de perto, obrigariam a um comprometimento (...) ${ }^{, 59}$, atitude típica da classe social à qual pertence grande parte das personagens lygianas: a alta burguesia.

(...) Assumi minhas curtas verdades, assumi as mentiras compridíssimas, assumi fantasias, sonhos - como sonhei e como sonho ainda! Tudo somado, um longo plano de evasão fragmentado em fugas miúdas. Diárias. Que foram se multiplicando, não leio mais jornais, desliguei a TV com suas desgraças em primeiríssima mão, crimes humanos e desumanos, catástrofes e calamidades naturais e provocadas, ah! um cansaço. Por que ficar sabendo

\footnotetext{
58 SILVA, Lilian Cristina Brandi da. Do romance de formação à deformação do romance: O silêncio, Os teclados e As horas nuas. (Doutorado em Letras- Literaturas em Língua Portuguesa). Instituto de Biociências, Letras e Ciências Exatas, Campus de São José do Rio Preto, Universidade Estadual Paulista, 2003, p. 46.

${ }^{59}$ CORONADO, Guillermo de La Cruz. Lygia e a condição humana. In: Letras de Hoje. Porto Alegre, PUCRS, v. 22, n. 1, mar. 1987, p.51.
} 
tudo se não posso fazer nada? Posso dar água aos flagelados ressequidos? (...) As tragédias se enredando sem trégua. Não tenho culpa se tomei horror pelo horror conformado. A miséria paciente. Minha mulher, doutor, mais o meu filho com barraco e tudo. Nem o cachorro salvou, sumiu no meio da água, do barro... A Dinamarca envia caixotes de vacinas, o Papa pede a Deus em português. Lá do alto do palanque os políticos filhos-da-puta exigem providências, Meus irmãos, meus irmãozinhos! E os irmãozinhos continuam morrendo como moscas, ah! querido Gregório, perdão, mas não suporto mais tanta miséria, merda! Fui batizada, catequizada, conscientizada e tudo isso para ter certeza de que não sou Deus e mesmo que fosse. Estou ciente, e daí?(...). (HN, p.10)

Ao longo de As Horas Nuas, a atriz raramente sai de sua 'concha', que na verdade, remete à imagem demoníaca ${ }^{60}$ da torre e da prisão escuras, geradoras de sofrimento; quando o faz, é para ir às sessões com sua analista, que mora no mesmo prédio. No interior do quarto, porém, o colchão é substituído por uma trouxa de roupas sujas, na maioria feitas de seda, e a cama cede lugar ao chão como espaço privilegiado e metonímico para os devaneios da protagonista. Elemento cuidadosamente utilizado pela escritora, o chão, repleto de sentidos de marginalidade e exclusão, também poderia ser compreendido como limiar, o ponto de contato com a realidade nua e, por isso, estaria em perfeita simbiose com o estágio atual em que se encontra a velha atriz, a situação de outsider: solitária, alcoólatra, idosa e excluída profissionalmente. Rosa é descrita por seu gato como alguém de pés bonitos, os quais circulam descalços pela casa e pelas escadas do prédio onde mora e do qual é majoritariamente proprietária; a ideia de contato dos pés com o chão não se realiza plenamente, no entanto, porque a dureza do piso é substituída pela maciez do carpete que o recobre, cobertura atapetada aplicada aos referidos ambientes por solicitação da protagonistasímbolo evidente do medo da nudez, do verdadeiro contato com a frieza do chão, estendida à crueza do conflito de ordem pessoal/social por ela vivido. Embora tenha tentado fugir dessa realidade, a 'resistência acolchoada' desse "espaço em camadas" em que se constitui sua concha-quarto-apartamento-prédio não impede, portanto, a reprodução da cidade em pequena escala, com seus múltiplos 'espaços sociais conflituosos', reiterados nas relações familiares, estratégia comum nas narrativas escritas por mulheres no Brasil ${ }^{61}$, que se dá na retomada de

\footnotetext{
${ }^{60}$ FRYE, Northrop. Anatomia da crítica. Tradução Péricles Eugênio da Silva Ramos. São Paulo: Cultrix, 1973. $\mathrm{Na}$ visão de Frye, os mitos e os símbolos arquetípicos na literatura ocidental organizam-se de três modos: "primeiramente, o mito não deslocado, que geralmente se preocupa com deuses e demônios, e que toma a forma de dois mundos contrastantes de total identificação metáforica, um desejável e outro indesejável" respectivamente, o apocalíptico e o demoníaco. Outras duas formas de organização metafórica consistiriam na tendência romanesca e a do 'realismo', com ênfase no conteúdo e na representação, não na forma e que tende ao mito, sugerindo seus padrões míticos, como regra, mais o demoníaco do que o apocalíptico (...). p. 141

${ }^{61}$ DALCASTAGNÈ, Regina. Sombras da cidade - o espaço na narrativa brasileira contemporânea. In: Estudos de literatura brasileira contemporânea, n. 21, Brasília, jan.-jun. 2003, p.47.
} 
lembranças do passado. Desse modo, família e passado ganham importância crucial em As Horas Nuas, assim como nos romances anteriores da escritora e em outras narrativas de autoria feminina,

(...) porque o dilaceramento das personagens geralmente se justifica pela infância reprimida e mal-amada. O resgate da memória é um dos caminhos para o autoconhecimento; a volta às origens, através do tempo passado, faz parte da busca de uma identidade, pulverizada em diferentes papéis sociais. ${ }^{62}$

Semelhante ao processo de análise, ao qual a atriz se submete sem sucesso, a possibilidade de 'cura' do seu estado atual de auto-rejeição está, portanto, no exercício da palavra que, ao longo do romance, assemelha-se a uma espécie de 'ensaio' do livro de memórias que pretende escrever.

A atriz sente-se como única responsável por sua degradação e, por isso, tem dificuldade de reconhecer sua própria face, uma vez que foram inúmeras as máscaras sociais por ela usadas, cujas características são as mesmas das dos membros de sua classe econômica e cultural, principalmente no que se refere à inadequação entre as ações praticadas e o discurso moralista pregado. A essência do trágico, cujo 'espírito' mantém-se como base do drama moderno, residiria, pois, na tensão entre a peripécia - "ação de uma personagem que consegue um resultado oposto ao esperado" ${ }^{63}$ - e a ironia dramática - "provocada pela frustração do herói trágico que vê seu plano de vida aniquilado pelos desígnios insondáveis do fado" ${ }^{64}$. Em Rosa, no entanto, o 'destino' é reconhecido como as condições que atuam principalmente no novo papel da mulher e na nova configuração familiar, com a concomitância de problemas de ordem psicológica e social, o que revela não apenas o elemento trágico na protagonista, mas sobretudo, o dramático. A consequência dessa tensão em Rosa recai na acepção de trágico de Northrop Frye ${ }^{65}$, como aspecto geral do 'enredo', que pode ser interpretada como seu isolamento da sociedade à qual pertence. Nesse sentido último, é possível compreender que, embora o projeto profissional tenha sido bem sucedido até chegar à velhice, é na nova condição de mulher idosa que a atriz se frustra com a inversão de planos e com o poder da lógica de aparências da sociedade em que vive, cujo 'modelo' de família também entra em franca decadência.

\footnotetext{
${ }^{62}$ XAVIER, Elódia. Reflexões sobre a narrativa de autoria feminina. In: (org.) Tudo no feminino - a mulher e a narrativa brasileira contemporânea. Rio de Janeiro: Francisco Alves, 1991, p. 13.

${ }^{63}$ D'ONOFRIO, Salvatore. Teoria do texto 2- teoria da lírica e do drama. São Paulo: Ática, 2000, p. 152.

${ }^{64}$ Ibid., p. 153.

${ }^{65}$ FRYE, Northrop. Anatomia da crítica. Op.cit.,p. 41-42.
} 
Há um traço dramático em As Horas Nuas, utilizado aqui na acepção adjetiva apontada por Anatol Rosenfeld ${ }^{66}$, que extrapola a questão da representação no âmbito meramente temático. Esse traço se configura na própria estrutura da obra, marcadamente nas personagens que 'narram' em primeira pessoa. Assim como na "dramática pura”, ao longo do romance em questão existe uma situação existencial com o objetivo de estimular a mudança de status quo das personagens mencionadas, a saber, a tensão entre expor e ocultar memória e realidade. A encenação, de origem dramática ou cinematográfica, visa a um futuro desconhecido, que brota do desenvolvimento de ações no presente, embora, no teatro, as "dramatis personae" possam evocar situações e eventos anteriores ao momento da enunciação. Diferentemente de uma peça teatral, no entanto, no romance e no cinema, há a possibilidade de se voltar ao passado, com o recurso do flashback, o que denuncia a ação de um narrador ou de alguém por trás da câmera, manipulando a narrativa, escolhendo - e isso implica evidentemente uma postura ideológica- o que deve ser dito ou mostrado ao leitor, ao público. No caso de As Horas Nuas, por trás de Rosa Ambrósio, Rahul ou a onisciência seletiva que apresenta a personagem Ananta oculta-se o autor implícito que, a partir desses diferentes pontos de vista, recorta e manipula o que deve ficar claro e o que deve permanecer obscuro na economia do livro. Como nos romances modernos, em As Horas Nuas "espaço, tempo e causalidade foram 'desmascarados' como meras aparências exteriores, como formas epidérmicas por meio das quais o senso comum procura impor uma ordem fictícia à realidade" e nesse processo, o ser humano "também se fragmenta e decompõe no romance"67. Como a personagem Rosa está profundamente envolvida nas situações recordadas, não há a distância que produz a visão centralizada num alguém que narra, mas exigem-se "adaptações estéticas capazes de incorporar o estado de fluxo e insegurança dentro da própria estrutura da obra"68. Essas adaptações traduzem-se mesmo na técnica utilizada - monólogo e monólogo interior- e no cruzamento da exploração da vivência subjetiva da atriz com a de seu gato e da analista, o que se dá num jogo de espelhamento que revela a precariedade das perspectivas no enfoque do real e que se constitui, no caso de Rahul, em uma espécie de imagem refletida da

\footnotetext{
${ }^{66} \mathrm{O}$ crítico, rediscutindo a questão dos gêneros literários, presente em diversos manuais de teoria da literatura, sintetiza duas acepções distintas para o uso de épica, lírica e dramática: um substantivo e outro adjetivo. A primeira acepção está "associada à estrutura dos gêneros", e a segunda, aos "traços estilísticos de que uma obra pode ser imbuída em maior ou menor grau, qualquer que seja seu gênero". ROSENFELD, Anatol. Gêneros e traços estilísticos. In: O teatro épico. São Paulo: Perspectiva, 1994, p.15-19. A caracterização dos gêneros mediante os dois significados se faz útil, inclusive, para compreendermos como essa questão, discutida desde tempos remotos, ainda é pertinente em tempos em que se apregoa a crise da própria representação.

${ }^{67}$ ROSENFELD, Anatol. Reflexões sobre o romance moderno. In: Texto/Contexto I. São Paulo: Perspectiva, 1996, p. 85 .

${ }^{68}$ Ibid., p.86.
} 
atriz, e em seu avesso, no que se refere a Ananta. Assim, a possibilidade de narrar torna-se remota, pois o narrador é como que dissolvido no monólogo interior/fluxo de consciência das personagens e a distância entre matéria narrada e leitor é reduzida, se comparada à distância mantida pelo romance tradicional.

A estrutura dialógica com suas réplicas, característica do texto dramático, corresponde em As Horas Nuas, à alternância da entrada em 'cena', individualmente, de Rosa, Rahul e Ananta, os quais, quando se encontram na mais pura solidão, parecem encenar para o também solitário leitor. Cada capítulo que se inicia parece corresponder à abertura da cortina para o monólogo ou análise mental dessas personagens, aos diferentes atos da peça teatral; os raros diálogos, no presente da narrativa, resumem-se às pequenas conversas entre Rosa e a empregada, a filha e a analista, além da conversa que Renato Medrado trava com o delegado de polícia responsável pela investigação sobre o desaparecimento de Ananta. Embora Rosa e Rahul também resgatem diálogos e interpretem situações passadas que envolvem Gregório, Diogo ou as personagens rememoradas ou inventadas pelo gato, são mais frequentes os questionamentos no fio de suas lembranças ou invenções. O discurso de Rosa também é marcado pela referência ao teatro, em que o uso das expressões 'entrar' e 'sair de cena' são constantes. A atriz ressalta que tem uma queda pelo estilo dramático, o que, segundo a personagem, é herança de sua mãe ${ }^{69}$, como revela a 'encenação' repentina de um excerto de Romeu e Julieta, para um público formado apenas por Dionísia:

Fico de pé em cima da cama tomada bruscamente por uma alegria delirante, rodopiou o teto e eu rodopiei com ele, Agora! grito e caio de joelhos nos travesseiros, Presta atenção, Dionísia, estou representando, Ah! Minha ama, pergunte seu nome. Se for casado, a tumba será meu leito nupcial! (HN, p. 119)

A ambiguidade do estilo remete diretamente ao duplo sentido do termo, como algo ou

\footnotetext{
${ }^{69}$ É interessante notar aqui como Lygia alia elementos da caracterização da personagem materna de Rosa Ambrósio com aqueles utilizados na representação de sua própria mãe, anos mais tarde, em "Nada de novo na frente ocidental", conto que integra o volume Invenção e Memória e cujo título remete ao filme "All quiet on the Western Front", cuja cena antológica do soldado-menino que morre quando admirava uma borboleta é mencionada por Lygia em As Horas Nuas. No referido conto, Lygia, como personagem, remete às recordações de um episódio que antecede a viagem de sua mãe à cidade de Aparecida, dia em que também a escritora é avisada da morte de seu pai. Lygia refere-se ao 'estilo' dramático de sua própria mãe quando comenta a reação desta diante da informação da filha de que participaria do Batalhão de Defesa Passiva Antiaérea, no final da Segunda Grande Guerra. Este é mais um exemplo de como fatos são por ela trabalhados e retrabalhados, os quais ganham diferentes revestimentos ficcionais em seus mais diversos escritos - seja em textos de caráter enganosamente mais autobiográfico como em Invenção e Memória (a partir da fusão com o imaginário, que transcende os textos desse livro como exemplos típicos de 'escrita de si', para caracterizá-los como contos), seja em romances como As Horas Nuas.
} 
comportamento ligado à emoção e como as peças que encenam conflitos da vida real. Por essa razão, a tragédia e o drama são as formas da dramaticidade à qual a velha atriz dedicou toda sua carreira. A força das personagens das peças por ela encenadas como Hamlet, Vestido de Noiva, Quem tem medo de Virginia Woolf? (Who's Afraid of Virginia Woolf?) ou apenas mencionadas como Macbeth, Othelo, À margem da vida (The Glass Menagerie), Fausto ou Longa Jornada Noite Adentro (Long Day's Journey into the Night) ${ }^{70}$, reside justamente no fato de que todas elas carregam traços demasiadamente humanos, em que a tensão entre aparência e realidade, bem e mal são parte mesmo de seu caráter ${ }^{71}$, fugindo do maniqueísmo, característica comum às personagens de Telles em sua vasta obra. Por essa razão,

(...) não é por acaso que a protagonista de As Horas Nuas seja uma atriz, cujos papéis representados se confundam com a mesma: ser e máscaras se enleiam, formando a personagem em detrimento da pessoa. Fato que remete à origem da Tragédia, que visando render homenagem a Dionísio, seus cultuadores se apresentavam mascarados. Durante o ritual as características místicas inerentes às máscaras eram transferidas e incorporadas por seus cultuadores. O mesmo sucedendo com Rosa Ambrósio que se vestia de papéis $(. ..) .^{72}$

Em todas as personagens encenadas profissionalmente ou apenas mencionadas por Rosa, pertencentes, em sua grande maioria, a uma classe social privilegiada - Ofélia, Lady Macbeth, Margarida, Alaíde, Martha, Amanda, Margueritte, Princesa Cosmonópolis -, a loucura, o desencontro, a incomunicabilidade, o abandono, o peso do passado, o apagamento das fronteiras entre ilusão e realidade decorrem dos dilemas do relacionamento conjugal e/ou da estrutura familiar. Estes são configurados pela manutenção ou desagregação da ordem patriarcal, mantida a fidelidade aos contextos em que aquelas peças foram escritas e publicadas, dos quais a sede de poder, a vingança, a inveja, o ciúme, a traição e a manutenção

\footnotetext{
70 Embora tais peças teatrais tenham um sentido de denúncia e/ou contestação da ordem vigente, que no caso dos dramas norte-americanos está ligado ao desmascaramento dos efeitos do 'sonho americano' sobre a vida das personagens, esse sentido não será explorado aqui devido à maneira como Rosa recupera os textos encenados como seus espelhos -, justamente por desprovê-los de contextualização, em perfeita sintonia com sua própria condição de burguesa 'alienada'.

${ }^{71}$ A existência do bem e do mal, como parte do ser humano, tem uma explicação mitológica ligada ao deus do teatro, Dioniso. Segundo Junito Brandão, o pequeno Dioniso (Zagreu) fora atraído pelos Titãs, a mando de Hera, que o fizeram em pedaços, os quais foram cozidos num caldeirão e depois foram devorados. "Zeus fulminou os Titãs e de suas cinzas nasceram os homens, o que explica no ser humano os dois lados: o bem e o mal. A nossa parte titânica é a matriz do mal, mas como os Titãs haviam devorado Dioniso, a este se deve o que existe de bom em cada um de nós.” BRANDÃO, Junito. Mitologia Grega. Op.cit., p.118. Daí a noção de metamorfose estar associada também a Dioniso.
}

72 ALCÂNTARA, Liem Hani. Palavra: rota de salvação em Xerazade e os Outros e As Horas Nuas. Op.cit., p. 42. Esse é apenas um aspecto da questão da intertextualidade que o romance estabelece com as peças mencionadas. Trataremos ao longo deste trabalho das representações sociais às quais essas máscaras remetem. 
das aparências são fruto de uma instituição familiar tida como repressora - suas consequências mais aparentes. A única exceção é Arlequim polido pelo amor (Arlequin poli par l'amour), de Pierre de Marivaux, uma comédia francesa do século XVIII, escrita nos moldes da commedia dell'arte italiana. $^{73}$

A técnica empregada por Lygia na apresentação de Rosa, Rahul e Ananta (que se repete ao longo de todo o romance), semelhante à de Virginia Woolf, garante a interposição de planos variados, graças ao uso de procedimentos que aprofundam ou radicalizam a análise mental, pois parte de um acontecimento exterior insignificante, para dizer com Auerbach, capaz de liberar "idéias e cadeias de idéias, que abandonam o seu presente para se movimentarem livremente nas profundidades temporais" ${ }^{\text {"74 }}$. Por isso, a simples referência ao sucesso com a peça Vestido de Noiva ${ }^{75}$, de Nelson Rodrigues, ocorre pela associação com os "tempos de muita roupa" (HN, p. 16) - em oposição ao momento vivido e criticado por Rosa no presente da narrativa, a década de 80, em que os corpos nus, belos e perfeitos explodiram na televisão e na mídia em geral-, a partir da lembrança da quantidade de botões do vestido que Rosa usara no próprio casamento, os quais Gregório nunca terminava de desabotoar. Esta é a única peça nacional citada, conhecida por ter renovado a dramaturgia brasileira moderna, por apresentar a fluidez da narrativa em diversas dimensões de tempo e espaço, diferentemente do que a platéia brasileira "estava acostumada a seguir, ao menos pela duração

${ }^{73} \mathrm{O}$ fato de citar apenas tragédias ou dramas, com exceção dessa comédia, está intimamente relacionado com o 'repertório pessoal de Rosa', como veremos em seguida. No caso da personagem arquetípica dessa commedia, o arlequim, a associação remete a Diogo e será explorada no capítulo III, em que também tratarei dos papéis de Rosa como esposa e amante a partir das peças Quem tem medo de Virginia Woolf?, Longa Jornada Noite Adentro e Macbeth.

${ }^{74}$ AUERBACH, Erich. A meia marrom. In: Mimesis - A representação da realidade na literatura ocidental. Op.cit., p. 487.

${ }^{75}$ RODRIGUES, Nelson. Vestido de Noiva: tragédia em três atos. In: Teatro completo- Peças psicológicas, v.1, 2.ed. Rio de Janeiro: Nova Fronteira, 2004. A peça, de 1943, retrata, em três diferentes planos - o da alucinação, o da realidade e o da memória-, a classe média carioca da década de 40, a partir da personagem Alaíde, jovem rica que é atropelada numa rua do Rio de Janeiro. No plano da realidade, tem-se a movimentação dos repórteres que buscam notícias sobre o estado da jovem, a conversa de Pedro, marido de Alaíde, com os médicos que tentam salvá-la, a morte da protagonista, o velório, o luto dos parentes e o casamento de Pedro com Lúcia, irmã da jovem morta. Os planos da alucinação e da memória confundem-se num misto de projeções em que Alaíde procura por uma prostituta, Madame Clessi, que havia residido na casa em que então moravam seus pais e que fora assassinada no início do século XX, por seu namorado, um rapaz de 17 anos. Alaíde encontra na figura de Clessi a base para a reconstrução de fatos passados e da revelação de seus desejos, a partir de sonhos como o assassinato de Pedro, o marido traidor. Recorda-se, com a ajuda da prostituta, cujo diário Alaíde havia encontrado no porão da casa de seus pais, que havia conquistado todos os namorados de Lúcia, sua irmã, inclusive o último, Pedro, com o qual se casara. Em seu delírio misturado às lembranças esgarçadas, demonstra sua frustração pela vida de casada, ao mesmo tempo em que se sente ameaçada de morte por Pedro e Lúcia. Alaíde tenta se lembrar do dia de seu casamento, da discussão com sua irmã e recorda que, dias antes do acidente, desconfia que será assassinada por Lúcia e Pedro. Enquanto o fio de vida se esvai, Alaíde tenta reconstruir em sua mente os acontecimentos passados, misturando-os à satisfação dos desejos mais recônditos. Por fim, a jovem rica e a cafetina assistem ao velório e enterro de Clessi e, com a morte de Alaíde, Lúcia casa-se com Pedro, mesmo tendo em sua mente a imagem da irmã no dia de seu casamento, vestida de noiva. 
de um ato, uma única ação, evoluindo linearmente no tempo e ocorrendo numa localização também única e específica."76

No que concerne às técnicas de representação, o paralelismo entre o drama de Alaíde, protagonista da tragédia de Rodrigues, e o de Rosa, evidencia-se na já citada interposição de planos espaço-temporais variados como os da realidade, da memória e da alucinação. No caso de Rosa, essa interposição é oriunda dos devaneios provocados pelo álcool, ao passo que a subconsciência de Alaíde é trazida à tona pelo estado de choque em que se encontrava no hospital para onde foi levada e operada. Lygia Fagundes Telles, como autora, introduz o plano da realidade em As Horas Nuas, à semelhança de Rodrigues, durante os devaneios de Rosa: em Vestido de Noiva, "a realidade tem o papel simples de situar os acontecimentos, estabelecendo-lhes cronologia e relação" "77, como o barulho das buzinas e dos automóveis, a tentativa dos médicos de salvar Alaíde ou as conversas entre jornalistas, os quais pedem e transmitem informações à redação dos jornais sobre a jovem da alta sociedade carioca atropelada, assim como em As Horas Nuas, quando a entrada ou a tosse de Dionísia, um de seus espelhos verdadeiros, tem a função de remeter Rosa ao presente e à realidade, interrompendo temporariamente o fluxo de suas lembranças.

Segundo Nunes, "as distorções da narrativa criadas pelas elucubrações subconscientes de Alaíde são, na realidade, um artifício dramático, que vai sendo gradualmente desmascarado, até que finalmente a realidade impõe-se por completo" ${ }^{, 78}$. Em ambos os casos, em Alaíde e em Rosa, os fatos passados, a matéria mais recôndita guardada no subconsciente das protagonistas vão emergindo a partir do exercício da rememoração em meio a um caos em que se misturam imaginação e realidade - sonhos, desejos, fantasias, romantismo, doces e amargas lembranças. A recordação do casamento, da traição do marido com uma mulher da mesma família (em Vestido de Noiva, a própria irmã de Alaíde e, em As Horas Nuas, uma prima de Rosa), da idéia de competição existente entre as mulheres, da necessidade de novas experiências para a figura feminina, que se sente encarcerada nos moldes, nos papéis predeterminados para a 'antiga' mulher, são os elos que unem essas personagens. O resultado, porém, tem nuances distintas: se em Vestido de Noiva a instituição familiar é alvejada de modo violento pelo autor a partir da decadência moral da classe social aí retratada - a

\footnotetext{
${ }^{76}$ NUNES, Luiz Arthur. Apresentação. In: RODRIGUES, Nelson. Teatro completo- Peças psicológicas, v.1. Op.cit., p.16.

${ }^{77}$ MAGALDI, Sábato. Nelson Rodrigues - A peça que a vida prega. In: Moderna Dramaturgia Brasileira. São Paulo: Perspectiva, 1998, p.24.

${ }^{78}$ NUNES, Luiz Arthur. Apresentação. In: RODRIGUES, Nelson. Teatro completo- Peças psicológicas, v.1. Op.cit., p. 17.
} 
burguesia carioca-, em As Horas Nuas, a vida familiar burguesa é fonte de dor mas sem a caracterização quase grotesca; nela, Rosa parece apostar suas últimas fichas, por desejar reconstruir sua relação com Diogo.

A referência teatral mais importante para Rosa consiste, no entanto, na tragédia de William Shakespeare, Hamlet - o Príncipe da Dinamarca- seu primeiro grande papel. A rememoração da personagem Ofélia, assim como todas as outras que encenara, surge das divagações da protagonista, que passa grande parte do tempo, como vimos, desejando voltar a ser uma atriz ativa, a responder à vida novamente "com êxtase e entusiasmo", para a qual o retorno de Diogo torna-se condição sine qua non, seguida da publicação de seu livro de memórias. Ao recordar o fato de sua filha manter relacionamentos amorosos com homens mais velhos, por exemplo, Rosa estabelece Gregório, já morto, como interlocutor mudo para quem menciona o comportamento de Cordélia com desprezo, atitude que seu marido condenava, pois achava que a liberdade era fundamental para que cada qual fizesse suas próprias escolhas. A opinião de Gregório sobre aquele assunto fica sugerida na frase retirada da peça mencionada: "Sê afável mas não vulgar! ele pediu" (HN, p. 46) ${ }^{79}$. Em seguida, a atriz instala sua própria dúvida no leitor: "Hamlet ou o tio?", sem saber se essa fora a frase dita realmente pelo marido, pela personagem de Hamlet ou de Polônio, o conselheiro que vive na corte da Dinamarca e é pai de Ofélia, personagem vivida por Rosa no teatro. Como se vê nessa passagem, a velha atriz também questiona os limites entre memória e ficção.

No fluxo contínuo da memória, ela recorda-se da longa cantoria de Ofélia, cuja extensão compara à loucura e à velhice ("loucura e velhice têm de ser compridíssimas"), e também de trechos de sua interpretação no palco, como o momento em que descia a escadaria cantando, coroada de flores, e do comentário feito pelo crítico de barbicha loura, que quis dormir com a atriz ("haja saco!"), de que ninguém resistia ao canto de Rosa nesse papel, semelhante a um 'doce sussurrar de águas puras'. Nesse mesmo fluxo, a protagonista acredita que representou bem o papel de Ofélia,

mas quando saí do palco a dor continuou enterrada no meu peito até o cabo. As personagens insistindo, uma noite cheguei a me assustar, era Hamlet e não Diogo que me apareceu com aquele queixo duro, eu querendo o

\footnotetext{
${ }^{79}$ Esta citação também é enunciada pela personagem Kori, do conto "Você não acha que esfriou?", referindo-se ao comportamento que deveria adotar diante da frieza do amante: o de revelar que o marido está apaixonado por uma secretária e que ambos esperam o nascimento de um filho. Num primeiro momento, Kori hesita em contar a Armando, seu amante, as novidades que se referem a Otávio, um sinal de pura afabilidade; posteriormente, depois de uma espécie de epifania quanto a sua própria condição de mulher, utiliza-se da crueldade ao contar de modo franco as peripécias do marido, que colocariam um fim nas expectativas amorosas que Armando tinha pelo amigo.
} 
Arlequim de coração contente e me vem um Pierrô sinistro, as narinas abertas intuindo podridões. Mas seu rancor era raro e breve (HN, p. 47).

Na peça de Shakespeare, a dor e a loucura de Ofélia são resultantes da morte de seu pai, da partida do irmão e também do afastamento do príncipe Hamlet, que envolve, em seu plano de vingança pela morte do rei Hamlet, a moça inocente. Sem a figura masculina protetora, do pai, do irmão ou de um marido, a jovem enlouquece e morre afogada. Ao ter de escolher entre a obediência ao pai - afastar-se do amado, futuro rei - e o amor de Hamlet, Ofélia fica com a primeira opção. Na conversa entre ela e Hamlet, forjada por Polônio e pelo Rei Claudius, a quem o príncipe deseja destruir por ter assassinado o seu pai, o jovem encena toda sua suposta loucura diante de Ofélia, acusando-a, inclusive, de desonestidade, pois sabia que aqueles dois a tudo ouviam, às escondidas, a fim de comprovarem que o estado de insanidade do príncipe originava-se também na desilusão amorosa provocada por Ofélia, sem que soubessem que se tratava de uma estratégia de vingança do herdeiro do trono contra seu antagonista.

Ofélia é, segundo Frye, a representação da figura do suplicante, comum nas tragédias, cuja imagem é a do completo abandono e desamparo. "Sua base é a exclusão de um indivíduo de um grupo, por isso ataca o medo mais profundo que temos em nós" ${ }^{\$ 80}$; as figuras mais comuns de suplicante são, além de crianças, mulheres ameaçadas de morte ou violação, bem como de personagens que se encontram na "posição estruturalmente trágica de ter[em] perdido um lugar de grandeza" ${ }^{\prime}$, como ocorre com Ofélia ao ser incluída no plano vingativo de Hamlet. Alguns críticos como A.C. Bradley concordam com a constatação de que da 'natureza infantil e da inexperiência de Ofélia tudo depende' e que embora não amasse Hamlet profundamente, deu-lhe todo o amor de que era capaz ${ }^{82}$. Nesse sentido, a dor pela perda do pai, a morte do primo por quem fora apaixonada e a decepção com o marido Gregório, Rosa sente e revive no conflito de Ofélia, figura feminina ligada à representação da protagonista de As Horas Nuas como muito jovem e inexperiente, motivos pelos quais Rosa sucumbe à troca de favor para obter um papel no teatro. Embora afirme que se casou virgem, comportamento preconizado pela Igreja e pela moral burguesa, a atriz também não amava o esposo profundamente como Ofélia e, por isso, passou a pautar sua vida amorosa na busca de homens que a satisfizessem ou a vingassem depois de descobrir a tola 'traição' do marido,

\footnotetext{
${ }^{80}$ FRYE, Northrop. Anatomia da crítica. Op.cit., p.214.

${ }^{81}$ Ibid., p. 214.

${ }^{82}$ BRADLEY, A.C. A tragédia shakesperiana: Hamlet, Otelo, Rei Lear, Macbeth. Trad. Marcelo Brandão Cipolla. São Paulo: Editora WMF Martins Fontes, 2009, p. 118.
} 
meses depois de seu casamento. No entanto, o sentimento de culpa pelas traições que também fizera a Gregório, juntamente com a chegada da velhice, seus efeitos sobre o corpo e o afastamento progressivo dos palcos levam Rosa ao limiar da loucura com a embriaguez, e permitem seus questionamentos mais redundantes, os quais dizem respeito aos homens de sua vida que foram embora: os amores perdidos (Miguel, Gregório e Diogo) e o pai que saíra para comprar cigarros quando ela ainda era uma adolescente e nunca mais voltara. Em sua vida presente, em que esses "esquecidos [voltam] com tamanha força, ululando nos sonhos e fora, uma conspiração" (HN, p. 47), sejam eles o pai, o primeiro amor, o marido, o amante, nos quais se incluem também o crítico de teatro, Rosa, na verdade, perde as referências entre realidade e imaginação, vestindo-se mais uma vez de personas, às quais, no entanto, não consegue corresponder no tocante aos papéis sociais que lhe são atribuídos: os de filha, esposa e mãe tradicionais. Ao levar para o ambiente doméstico o drama vivido no palco, dialoga, na vida real, com a problemática do relacionamento de sua personagem, chegando a colocar a máscara também no amante, anos depois desta encenação, o qual, num momento de rancor, apresentava um comportamento semelhante ao de Hamlet, pressentindo alguma mentira da atriz no ar - a figura da podridão, da corrupção da tragédia de Shakespeare - o que duraria, no entanto, poucos instantes. O processo de assumir como sua a dor da personagem acaba fundindo-a em Rosa, que toma dela características que passam a fazer parte de seu repertório, o que explica a projeção em Ofélia das insatisfações e desejos pessoais de Rosa; melhor dizendo: no drama vivido no palco, ela vê seus próprios conflitos espelhados, mas não consegue mais separar invenção de memória, pois a máscara está perfeitamente aderida.

Segundo Rahul, Rosa contara que, quando jovem, fora convidada para fazer o papel de Margarida, da tragédia Fausto, do escritor alemão Goethe. A atriz participou de alguns ensaios da peça, mas acabou desistindo da atuação; atribuiu à incompetência dos atores, do diretor e da cenógrafa o motivo dessa desistência. Em tom zombeteiro, após uma discussão com Diogo, afirmou:

-Há de ver que quem tinha razão era aquele diretor implicante, foi meu segundo papel. Me lembro que fazia tantas caras encarnando a pobre Margarida que por mim o doutor Fausto não venderia ao Diabo nem o botão do colete, quanto mais a alma. Hem?!... (HN, p. 30)

A verdadeira razão para essa desistência, no entanto, deve-se, mais uma vez, ao paralelismo que a protagonista estabelece entre sua tragédia pessoal e a da personagem a ser 
encenada no palco. Assim como a atriz antes do casamento ${ }^{83}$, Margarida era jovem, religiosa, virgem e pobre; vivendo numa situação de escassez de recursos, encanta-se com as jóias recebidas pelo galante Fausto e sucumbe aos seus desejos sexuais. É uma personagem romântica e pura, aparentemente corrompida por ser responsável, indiretamente, pela morte da mãe e do irmão. Abandonada por Fausto e com a família destruída, desiste da maternidade, afogando o recém-nascido, fruto de sua relação com o amado doutor e, por esse crime, é presa e condenada à morte. Depois de uma visão da pobre moça encarcerada, Fausto transporta-se para dentro da cela de Margarida e sugere-lhe que fuja juntamente com ele; a jovem, porém, permanece firme no propósito de pagar por sua dívida. Na morte, ela obtém a redenção: é salva e conduzida ao Paraíso, frustrando os planos de Mefistófeles.

É sintomático o fato de que Margarida tenha sido o segundo papel de Rosa no teatro, após Ofélia; no entanto, mais sintomática ainda é sua ligação com a perda sofrida por Rosa com a aceitação do papel de Ofélia em troca da entrega sexual ao diretor de teatro. A personagem Margarida encarna, portanto, a transição da inocência à experiência para a protagonista de As Horas Nuas. Rosa sente-se incapaz de representar seu segundo papel no teatro e dele desiste porque foi corrompida, mas se sente indigna de redenção, pois, ao contrário de Margarida, continuou a atender prontamente, como Fausto, aos desígnios de Mefistófeles. Assim, a protagonista de As Horas Nuas assume atributos típicos do caráter masculino da cultura, do desejo de domínio da 'natureza' por meio da 'razão', isto é, sua completa inserção no mundo dos 'homens': a busca do dinheiro, da juventude a qualquer preço, como parte do processo de autoconhecimento. A partir de então, os papéis encenados no palco não coincidem mais com personagens românticas e angelicais como Ofélia e Margarida, mas carregam os traços 'demoníacos', autodestrutivos, no comportamento de Martha ${ }^{84}$, de Quem tem medo de Virginia Woolf?, ou menos idealizados como os de Amanda, de À margem da vida e de Alexandra Del Lago em Doce Pássaro da Juventude, como veremos em seguida.

As 'tragédias' e 'dramas' pessoais de Rosa Ambrósio, portanto, nasceram das escolhas que essa personagem de espírito 'dramático' foi levada a realizar, em consonância com os ditames sociais, voltadas sempre para a manutenção das aparências, que, por sua vez, era reforçada pela crença de que, em sua beleza física, a atriz poderia encontrar a própria fonte da juventude e da felicidade. Quando chega à "idade da madureza”, é interessante notar que Rosa

\footnotetext{
${ }^{83}$ A caracterização de Rosa na adolescência será discutida, em detalhes, no capítulo "Memórias Deslumbrantes".

${ }^{84}$ A opção pela análise desta peça apenas no terceiro capítulo deve-se à necessidade de avaliação da construção das personagens masculinas de Gregório e Diogo pela ótica da protagonista.
} 
tenta desesperadamente estabelecer interlocutores em seu monólogo quase ininterrupto, o que corresponde ao esforço de transformar em diálogo o fluir solitário de sua consciência. A estrutura dialógica, característica do teatro, é uma forma de apresentar os conflitos a partir da ação dos atores em cena, com suas réplicas, sem interferência de um narrador. Seu uso, por Rosa, caracteriza-se como mais uma marca arraigada da atividade teatral na personagem e tem um duplo sentido no romance: vencer a solidão e tentar encontrar no outro a resposta para seus próprios conflitos pessoais. Dentre seus interlocutores preferidos, encontram-se Gregório, a mãe, o pai, Miguel - em suma, aqueles a quem ela não tem mais. Cordélia e Dionísia não entram completamente nesse 'jogo', pois a atriz ainda não as perdeu, mas Ananta será facilmente substituída por um gravador, que se assemelha, em seu silêncio e impossibilidade de réplica, ao comportamento da analista. No entanto, como Rosa reconhece, 'aqueles' mortos não ajudam. Os que realmente poderiam colaborar foram eliminados de seus guardados, tiveram suas fotografias rasgadas, excluídos como testemunhas capazes de apontar o processo de mentiras e degenerações a que se entregou. Seu inevitável reencontro com 'esses mortos' dar-se-á na Praça da República, onde acontece uma espécie de renascimento da protagonista, ou, como Aristóteles preconiza na Poética, quando se dá o processo de 'reconhecimento', aspecto fundamental do mythos na Tragédia, da imitação de ações, o que não implica cópia mas recriação do real, em conformidade com o caráter e o pensamento das personagens, como afirmei anteriormente.

No episódio em que descobre que Diogo havia telefonado, Rosa dirige-se a uma clínica de desintoxicação e, ao entrar no consultório, nota a semelhança física entre o médico e o ex-secretário/amante, mas percebe que aquele não poderia ajudá-la. Para desvencilhar-se do local, usa mais de suas mentiras, como a desculpa de que marcara aquela consulta no mesmo horário do ensaio da peça À margem da vida (The Glass Menagerie), do estadunidense Tennessee Williams, em que atuaria como Amanda Wingfield, papel que, segundo Rosa, 'sempre' quis fazer. Trata-se de uma 'memory play', cuja ação é delineada a partir das memórias do narrador Tom Wingfield, que organiza os fragmentos dispersos, e tem por cenário o apartamento da família Wingfield, na St. Louis de 1937, durante a Depressão Norte-Americana. Tom é o responsável pelo sustento da casa onde mora com sua mãe, a sonhadora Amanda, e sua irmã, Laura. Todas as personagens têm uma experiência de abandono e fragilidade, o que se dá inicialmente pelo fato de Mr. Wingfield ter deixado a família há anos e que tem na metáfora dos bibelôs de cristal (the glass menagerie) que Laura colecionava, sua expressão. Tom desejava ser um poeta e fugir do ambiente doméstico no qual se sentia sufocado, impedido de alçar vôos mais altos, sob o peso da responsabilidade 
para com a família. Sua irmã Laura é manca e apresenta um complexo de inferioridade que a impede de superar a dificuldade de se relacionar com o mundo exterior. Diante da percepção do desejo do filho de também ir embora, Amanda impõe a condição de que, antes de partir, Tom precisaria encontrar um pretendente para Laura, uma espécie de substituto para o posto de ganha-pão da família. O que Amanda tenta fazer é garantir seu futuro e o da filha às custas de uma figura masculina, tentando repetir o mesmo esquema tradicional a que se submeteu. Essa tentativa é frustrada, pois o pretendente trazido por Tom, um antigo amor de sua irmã, estava noivo, o que direciona Laura para uma situação definitiva de incapacidade para a vida. Depois de uma forte discussão com Amanda, Tom deixa a família, mas a lembrança de Laura é acompanhada de grande remorso, o que faz concluir que, mesmo tendo ido embora, ele não conseguiu deixar sua família - a memória é a inquiridora de todas as personagens, assim como ela também o é para Rosa Ambrósio.

Utilizando o artifício da representação como invenção, no sentido de mentira, a atriz confunde uma vez mais os limites com a realidade, tal como Amanda, mas a referência a esta peça assume novas conotações. A Mrs. Wingfield, como Rosa, passa de uma mocidade feliz a uma velhice solitária: quando jovem, não lhe faltaram pretendentes, festas e participação ativa nas rodas sociais; no presente, resta-lhe que a memória possa “(...) embelezar o passado na recriação mítica de um tempo perfeito, para oferecer-lhe agasalho contra a rudeza atual(...)"85. Para ambas as personagens, a figura masculina se faz necessária na projeção de futuro, mas com ênfases diferentes: se, para Amanda, tal figura teria a função de provedor da casa, para Rosa a simples companhia de Diogo deveria garantir sua luta contra a solidão, ao passo que a função de mantenedora das necessidades financeiras do amado, papel tradicionalmente atribuído ao 'homem da casa', ficaria a cargo da velha atriz. Por outro lado, Amanda seria o prenúncio da aceitação de um papel de uma mulher de meia-idade, cujas características foram incorporadas pela atriz: fantasiosa, sonhadora e impetuosa. O título da peça em português, À margem da vida, oculta do médico, mas revela ao leitor, a partir das técnicas de representação utilizadas pela autora, a maneira como Rosa compreende sua atual condição de outsider, de quem realmente está à margem, vítima de preconceitos também enraizados na própria atriz, no que tange à velhice e à passagem do tempo.

$\mathrm{Na}$ cena em que enfim consegue sair da clínica, Rosa passa por muita gente nas calçadas até encontrar um táxi, cujo motorista está impregnado pela implacável dureza e pela impaciência da cidade. A atriz percebe que esquecera, no consultório, os óculos escuros,

${ }^{85}$ MAGALDI, Sábato. Tennessee Williams evoca o passado. In: O texto no teatro. 2. ed. São Paulo: Perspectiva, 1999, p. 354. 
companheiros de longa data, com os quais se protegia da luz, do sol, considerado seu inimigo; esse esquecimento configurar-se-á como a metáfora catalisadora da iminente transformação da protagonista. A partir desse momento, Rosa é obrigada a encarar o sol e a realidade da cidade onde mora, sem artifícios que pudessem impedi-la de reconhecer sua complexidade e sofre um primeiro impacto: ela pede ao motorista que siga ladeira abaixo. Diante da impaciência e da grosseria do taxista, que precisa saber o destino certo da ocupante, Rosa pede que ele entre na Praça da República; sente-se diminuída, novamente, em meio ao desconforto do veículo e do trânsito caótico de São Paulo e, numa atitude de autodefesa, apela para mais uma de suas representações: atribui a culpa de seu estado de atordoamento ao fato de ter acabado de voltar de um hospital, onde uma pessoa que ela amava muito estava morrendo. O motorista afirma que, mesmo pagando, não é possível que Rosa passeie por aquele trecho congestionado e sugere que ela desça na esquina mais próxima. Ao notar que o motorista se comoveu, pois desejou que seu enfermo melhorasse, Rosa sente seus olhos dançarem "nas lágrimas do doente que não existe" e observa, por si mesma, que foi "além da representação" (HN, p. 171). No momento da saída do táxi, titubeia: "é melhor não entrar" na praça, precisa "ficar no casulo", mas “até quando?” (HN, p. 171). No interior de seu "mundopara-si", a atriz, assim, como outras protagonistas de Telles, também apresenta uma imensa dificuldade de dar o passo em direção à saída diante das 'situações dramáticas' a serem enfrentadas, dificuldade que, como vimos, está calcada no medo. Na ficção de Lygia, a saída do ambiente doméstico é indício de um iminente processo de renascimento ou transformação, que vem acompanhado sempre pelo abandono da escuridão do quarto em favor da claridade do dia, que metaforicamente representa a 'luz', a resposta para os seus questionamentos. Esse deslocamento da atriz do edifício onde mora em direção à rua, semelhante à saída de Raíza, de Verão no Aquário, rumo à igreja no final do romance, é um indicador textual de uma primeira abertura da 'concha', uma espécie de enfrentamento dos fatos depois de anos de autorreclusão em seu apartamento - uma possibilidade de experiência ${ }^{86}$. Mabel Knust Pedra faz uma observação complementar, no estudo que realiza sobre Ciranda de Pedra e alguns contos de Lygia Fagundes Telles, de como características do tempo meteorológico aliam-se ao tempo psicológico, no referido romance, "no desvendamento de questões conflituosas, e termos relacionados aos eventos climáticos se tornam índices de acontecimentos que vão

\footnotetext{
${ }^{86}$ SANTOS, Ana Paula dos. O eu e o outro: retratos de mulheres em dois romances de Lygia Fagundes Telles. Op.cit., passim.
} 
trazer importantes transformações" ${ }^{87}$, normalmente situações que envolvem grande tensão psicológica. Com a solução ou o alívio da tensão, “desfaz-se ou ameniza-se o elemento natural que emoldurou o momento de aguda interioridade" ${ }^{\text {}} 88$, como também acontece em As Horas Nuas.

Rosa vê a praça da sua infância, onde costumava ir com o pai e assusta-se com a degradação da cidade e da própria civilidade, explícitas na miséria transbordante que ocupa a antiga praça de suas boas lembranças, tomada por cabeludos fazedores de pulseiras e camelôs com suas bancas repletas de doces expostos ao vento - os verdadeiros outsiders. Diante dos bustos depredados, de "homens que ninguém mais conhece", Rosa sente na pele a perda do sentido de história, de passado e da própria memória, que acompanha a cidade, representada pela praça de antigos gramados londrinos. Ao não reconhecer o antigo espaço utópico, ligado à infância e à inocência, Rosa parece se dar conta do lado negro da modernização ocorrida, que induziu a um processo de urbanização/exclusão sem precedentes e que gerou uma megalópole marcada pela violência, "pela desestabilização de valores, pela lógica da exclusão" ${ }^{89}$, num período que se estende do final dos anos 40 até o final da década de 80 , e que coincide com a passagem de sua infância à velhice. Percebe, então, aquele espaço como conhecido e desconhecido, símbolo das transformações rápidas e profundas que se operaram na sua cidade, como a evidente perda de elos comunitários, que passou a abrigar todas as classes sociais, desde a alta burguesia, que é a da protagonista, passando pela operária e chegando aos mascates, aos sem carteira assinada, aos sem teto. A cidade é vista pela personagem como uma

imensa arena de discursos gastos e dispersos, lugar da inscrição e rasura dos signos que desafia o olhar do habitante, que busca ler a ilegível linguagem da cidade dimensionada na metrópole que perde o seu métron: a forma das cidades sem forma, em que a desmedida do espaço afeta suas relações com o humano. A cidade, assim, vai-se qualificando como a Babel que prospera com a perda das conexões e a falta de referência aos valores do passado. É palco para a atrofia progressiva da experiência ligada à tradição, à memória válida para toda a comunidade, substituída pela vivência do choque, ligada à esfera do individual..$^{90}$

\footnotetext{
${ }^{87}$ PEDRA, Mabel Knust. O círculo de giz: a família burguesa patriarcal em Lygia Fagundes Telles. Dissertação (Mestrado em Letras - Área de concentração: Estudos de Literatura). Niterói, Universidade Federal Fluminense, 2005, p. 28-29.

${ }^{88}$ Ibid., p. 29.

${ }^{89}$ GOMES, Renato C. A cidade, a literatura e os estudos culturais: do tema ao problema. Ipotesi: Revista de estudos literários. Juiz de Fora, v. 3, n. 2, p. 19-30, 1999. Disponível em $<<$ http://www.ufjf.br/revistaipotesi/files/2009/12/A-CIDADE-A-LITERATURA-E-OS-ESTUDOS1.pdf $>$. Acesso em: 08 maio 2006.

${ }^{90}$ Ibid., p. 26.
} 
Mais do que isso: com esse recurso, Lygia situa Rosa num espaço que se consolida como representação metonímica de uma São Paulo que abarcou em um período de 40 anos uma 'sociedade em movimento" ${ }^{91}$, em que a protagonista é mais uma na multidão, com seus próprios problemas e sente que está "livre do flagelo de sair da moda, de ficar um dia como esses pobrezinhos que já saíram faz tempo e continuam em exposição (...)”(HN, p. 172). Assim, "o lamento da protagonista se deve não só à perda, mas também à percepção da enorme distância entre tempo vivido e presente, algo que expõe tanto perdas exteriores (sujeira, miséria, violência) quanto interiores (envelhecimento, decadência, esquecimento)"92. A atriz garante, repentinamente, que perdera o medo e a ambição, pois se reencontra com o símbolo de seu "paraíso perdido" 93 , a praça, local frequentado na infância, em que se sentia feliz e segura. Esse reencontro, então, corrobora a passagem para seu suposto renascimento interior, tal como um rito de passagem:

O retrato que tirei com meu pai onde foi parar? Rasguei tanta papelada, cartas e documentos rotos dentro dos plásticos rotos. As testemunhas picadas em pedaços tão miúdos - adiantou? Aos poucos elas vão se refazendo e me seguindo passo a passo na procissão lamurienta, eu sangrando na frente com a cruz da memória. Resisto, empaco, quero fugir e Eleonora me segura pelo braço, está atenta. (HN, p. 173)

Nesse fragmento, tem início o processo de revelação da origem do medo da atriz por meio de um procedimento narrativo em que a autora implícita instaura as duas primas de Rosa, Eleonora e Zelinda, como as testemunhas que se refazem no fluxo de lembranças e refazem em retrospectiva o passado obscuro da protagonista. Trata-se, desta vez, de um recurso ligado à dificuldade de comunicação e à culpa da atriz, que, ao dar uma voz imaginária às duas personagens já mortas, permite que ambas apontem a verdade que, enfim, vem à tona, pois Rosa não é capaz de dizê-la por si mesma, embora toda essa matéria seja constituída de lembranças, dentro de seu fluxo de consciência. Desse modo, a protagonista,

\footnotetext{
91 NOVAIS, Fernando A.; MELlO, João M. Cardoso de. Capitalismo tardio e sociabilidade moderna. In: SCHWARCZ, Lilia M. (org.) História da Vida Privada no Brasil: contrastes da intimidade contemporânea. V.4. São Paulo: Companhia das Letras, 1998, p.585.

92 LUCENA, Suênio Campos de. Esquecimento e lembrança em Lygia Fagundes Telles. Tese (Doutorado em Teoria Literária e Literatura Comparada). Faculdade de Filosofia, Letras e Ciências Humanas, Universidade de São Paulo. São Paulo, 2008, p.126. O autor argumenta que na região central, mais especificamente na Praça da República, Rosa rememora o paraíso perdido da infância e juventude, e ao voltar lá, aciona lembranças e o desejo de restabelecê-lo. A partir do episódio nessa praça, o autor revela os mecanismos de lembrar e esquecer no último romance de Telles que tematiza a memória como tentativa de reconstruir o vivido.

93 Ibid., passim.
} 
desdobrada em duas narradoras-testemunhas imaginárias, muda o ângulo de visão, em que a narração tem como objeto narrado sua verdade mais recôndita, em que Rosa sente ainda mais o pesado fardo que carrega, pois se coloca na posição de quem observa e é observada, de quem aponta e é apontada. O fantasma imaginário de Eleonora é responsável por avivar, com perguntas, a memória de Rosa sobre o dia de seu casamento com Gregório, quando a futura atriz chorava copiosamente, antes da cerimônia, chamando pelo primo Miguel, situação que sua mãe procurava disfarçar ao se referir à festa e ao vestido com metros de cauda de cetim, um verdadeiro casamento de princesa, ocultando as dívidas que assumira para manter as aparências e a dívida maior da filha com o futuro esposo.

É Zelinda, no entanto, a responsável por trazer à tona as revelações mais cáusticas, uma vez que está intimamente ligada a um acontecimento importante para a prima artista. Pelo reflexo do espelho em formato de sol, no centro do biombo art noveau que ficava em sua sala de jantar, Rosa viu, anos antes, o beijo de Gregório e Zelinda, enquanto fora buscar pão na cozinha, durante o jantar oferecido à prima que acabara de ser nomeada para o cargo de Consultor Jurídico: “Aplausos para a futura grande atriz que representou perfeitamente o papel da esposa traída e distraída. Mais um pouco e já acabo, é dolorido, eu sei, mas é preciso ir até o fundo, você descobriu e continuou igual, tão alegrinha com a cestinha de pão" (HN, p. 174). Dessa revelação, surgem outras mais contundentes, como a de que a protagonista sucumbira ao desejo do diretor teatral de 'barbicha loura' em troca de seu primeiro grande papel no teatro: Ofélia. É curioso notar que essa lembrança, rememorada antes como algo aparentemente insignificante - supondo inclusive que Rosa não cedera ao desejo do crítico de teatro - só ganha relevo e explicação neste episódio, capítulos depois, quando a protagonista, travestida de Zelinda, esclarece que tal fato acontecera um mês após o 'famoso' jantar, dando início ao jogo de traições, mentiras e desagregação familiar e pessoal da protagonista, embora insistisse na 'normalidade' das aparências.

A atriz compara o afastamento de Zelinda com o vôo de um pássaro que se junta aos outros na copa de uma das árvores da praça e na mais velha delas depõe sua cruz: "as testemunhas voltaram aos seus ninhos, a copa aqui da árvore está fervilhante” (HN, p. 175). Não é gratuita a presença desses dois grandes símbolos na representação do suposto renascimento e explicitação do conflito de Rosa: árvore e pássaros. A primeira é símbolo da vida e das relações que se estabelecem entre o céu e a terra; ela é o "caminho ascensional ao 
longo do qual transitam aqueles que passam do visível ao invisível"94; em perpétua evolução e em ascensão para o céu, simboliza também o aspecto cíclico da evolução cósmica: morte e regeneração ${ }^{95}$. Já os pássaros estão associados “à representação da alma que se liberta do corpo ou apenas o símbolo das funções intelectuais", como a inteligência ${ }^{96}$. No episódio em questão, os pássaros estão ligados à figura de Zelinda, como a representação imaginária da alma da prima já morta que, depois de trazer à tona o que estava reconditamente guardado em Rosa, volta para a copa de uma árvore, como se regressasse à outra dimensão: já cumpriu seu papel de conectar os dois mundos, terra e céu, consciente e inconsciente da protagonista. É no local de reencontro do passado escondido - a praça com suas árvores e pássaros- que Rosa se sente perdoada, que a conspiração formada pelos seus mortos se dissipa e permite que ela possa, ao menos por ora, começar a viver a vida que lhe resta, pois já não é possível mais encontrar a praça da infância, nem os amores da adolescência, nem a inocência do primeiro amor. A velha atriz parece despir-se de sua última máscara.

É interessante notar que o perdão a Rosa, vindo simbolicamente da natureza, é sugerido capítulos antes, em uma passagem em que a atriz, entregue aos cuidados de Dionísia enquanto toma uma gemada, motivada pelo cheiro do ovo e do açúcar, volta ao "tempo das gemadas”, à adolescência, pelo exercício proustiano da memória do sentimento ${ }^{97}$ : “(...) Tempo das gemadas. Tempo do Miguel, engulo a colherada de gemada e fico mocinha, quase menina. Ele morava na minha rua, era o meu primo rico e lindo, eu estava tão apaixonada. Tão apaixonada mas faz tempo, hem?! Passou” (HN, p. 118). Para Lilian Brandi da Silva,

evocar o passado por meio de sensações olfativas e gustativas não é um gesto buscado pela personagem e sim um impulso que vem involuntariamente, trazido por necessidades interiores que o elemento exterior (gemada) apenas acionou, mas intensificou com o poder da própria linguagem. Só que em Lygia (...) o peso do passado é desnudado por um jogo hábil que desmonta a própria seriedade ou densidade dos fatos. ${ }^{98}$

\footnotetext{
94 CHEVAliER, Jean; GHEERBRANT, Alain. Dicionário de símbolos- mitos, sonhos, costumes, gestos, formas, figuras, cores, números. Tradução Vera da Costa e Silva et al. 22. ed. Rio de Janeiro: José Olympio, 2008, p.85.

95 Ibid.,p. 84.

${ }^{96}$ Ibid, p. 687.

${ }^{97}$ Lilian Brandi da Silva também observa que, nesta mesma passagem, “o 'cheiro do ovo e do açúcar' resgata o motivo da fixação na madeleine, pela personagem de Proust. SILVA, Lilian Cristina Brandi da. Do romance de formação à deformação do romance: O silêncio, Os teclados e As horas nuas. Op.cit., p. 100.

${ }^{98}$ Ibid., p. 100-101. Para Lilian, isso ocorre porque a "personagem- narradora desmascara a passagem temporal a partir da "amargura tingida de espirituosidade" e do "sarcasmo com que a subjetividade foca a si mesma", à diferença de Proust.
} 
$\mathrm{Na}$ construção textual de Lygia, no entanto, é comum que um fato como aquele, aparentemente sem importância e ainda reforçado por um certo desprezo da personagem 'faz tempo, hem? Passou.'-, seja seguido no mesmo parágrafo por outra lembrança, marcada pela culpa ou ressentimento, que, à primeira vista, não apresenta uma ligação evidente com o que foi recordado anteriormente, como a descrição de um quadro em que o perdão também vem da natureza é capaz de mostrar:

Vi num quadro o tronco de uma árvore se abrir pelo meio e da fenda sair a Deusa do Perdão estendendo os braços para abrigar Caim que fugia como se o chão fosse só serpente e brasa. Não esqueço, o perdão vinha da natureza, só ela aceitava o Caim negro e desgrenhado, mordendo as mãos e mordido, queria parar e não podia. Quero parar e não posso, fujo arrastando os sapatos de ferro, o coração de ferro... Horror, horror. Degenerescência cerebral, querida. Isso de se agarrar ao passado e começar como um rato, roque-roque, roendo as lembranças e se roendo. (HN, p. 118)

O silêncio que se estabelece entre a recordação do primo e a lembrança do quadro, com a dificuldade de pôr em prática a 'lição' de auto-aceitação que este representa ${ }^{99}$, é o elo capaz de revelar sua culpa - depositada em um passado recôndito, digno de vergonha por parte da personagem, relacionado com as figuras de Miguel e Gregório- e sugerir a resolução iminente de seu conflito. Esse aspecto, nos romances de Telles, de modo geral, ganha corpo na sugestão de renascimento posterior, final, das protagonistas femininas, quando estas decidem interromper a fuga constante ao ‘inimigo' e enfrentá-lo. Por essa razão, após sair da Praça da República, Rosa sente que o peso da cruz da memória está deposto em uma árvore e percebe que a multidão passa por ela preocupada com sua própria cruz. Esta última, como "instrumento de suplício e de redenção", congrega, portanto, em uma única imagem, "os dois significados extremos do significado maior que é a Árvore: pela morte para a vida - per crucem ad lucem, pela cruz para a luz" ${ }^{\prime 100}$, da memória martirizante à memória reconstrutora $^{101}$. Esse estado de leveza e contentamento, oriundos de seu estado renovado, vem expresso na figura do novo táxi que ela chama, o qual a levaria para a casa: o veículo, desta vez, é confortável e o chofer, gentil. Completa o quadro de sua espécie de 'ressurreição'

\footnotetext{
99 Vale lembrar que esse é o mesmo mecanismo utilizado pela escritora na passagem em que Rosa desdobra-se em sargento e recruta, analisada no início deste capítulo.

${ }^{100}$ CHEVALIER, Jean; GHEERBRANT, Alain. Dicionário de símbolos. Op.cit., p. 90.

${ }^{101}$ No capítulo "Memórias deslumbrantes", tratarei especificamente de um outro aspecto das memórias de Rosa, que se pretende reconstrutora de uma subjetividade fragmentada, mas que surgirá em seu avesso, como mais uma faceta de seu jogo de representação.
} 
a presença de nuvens brancas, prenúncio de que o sol voltaria a brilhar: agora "não há conspiração." (HN, p. 176) ${ }^{102}$

Ao final do romance, Rosa encontra-se internada em uma clínica de desintoxicação e, por meio de uma conversa com Renato Medrado, primo da analista desaparecida, à qual só se tem acesso quando o rapaz trava um diálogo com a empregada da atriz, Dionísia, descobre-se que Rosa deseja voltar aos palcos com Doce Pássaro da Juventude (Sweet Bird of Youth), de Tennessee Williams ${ }^{103}$, que tem um significado especial na composição de As Horas Nuas. A peça apresenta como temas centrais a busca da felicidade, que tem no tempo, na ambição competitiva e na solidão seus maiores inimigos - os quais foram também os dissabores que provocaram o estado depressivo de Rosa. Suas personagens centrais são Alexandra Del Lago, uma atriz de meia-idade, decadente, drogada e alcoólatra, e seu 'gigolô', Chance Wayne, um ator que tentou a sorte em Hollywood, mas fracassou e que busca associar sua imagem à da atriz, a fim de abrir, com mais facilidade, os caminhos que podem levá-lo ao sucesso. O rapaz volta a St. Clouds, sua cidade natal, com a atriz, certo de que esta cumprirá seu acordo de indicá-lo para um papel importante. Deste modo, Chance poderá, iludido pelo 'sonho americano' de 'ser alguém', dizer à mãe, e à sua namorada da adolescência, Heavenly Finley, que venceu e, assim, ter as condições materiais necessárias para levar sua amada para Hollywood: dinheiro, fama, nome. No entanto, ao chegar à cidade, Chance descobre que sua mãe está morta e que sua amada casar-se-á com um médico. A lição que todas as personagens parecem aprender é que o tempo passa e que as ações realizadas na juventude têm suas consequências no futuro. Alexandra deseja esquecer seu passado como uma das mais belas atrizes hollywoodianas, começando por seu nome - substituído pela expressão Princesa Kosmonópolis-, depois que o peso da idade se transforma em um fardo difícil de carregar na indústria cinematográfica americana, e vê em Chance a chance de se agarrar à juventude, 'o

\footnotetext{
${ }^{102}$ A figura das nuvens 'conspirando', que em As Horas Nuas também é utilizada em outra passagem, quando Rosa se refere ao ódio que as mulheres sentem umas pelas outras, remete a um episódio contado por Lygia $\mathrm{F}$. Telles, no livro Conspiração de nuvens, publicado pela autora em 2007- dezoito anos depois da publicação de As Horas Nuas. Neste volume em que os textos oscilam no tênue limite entre memória e invenção, ficção e realidade, a autora revela, no texto homônimo ao título do livro, que a metáfora da conspiração de nuvens referese à formação de tempestades e está relacionada com a viagem que fizera na companhia de Nélida Piñon e Hélio Silva, para entregar o Manifesto dos Mil Contra a Censura, nas mãos do Ministro Armando Falcão, durante o governo Geisel, em 1976. A entrega do manifesto, que deveria ser sigilosa, estava estampada no jornal que era lido por um ocupante de uma das poltronas do avião. Ao avisar Hélio do que vira no jornal, este alertou sobre a tempestade que se formava no céu. Assustada, Lygia confessa: "Uma conspiração de nuvens (...), Elas também conspiram, se não cairmos agora seremos presos na chegada" (p. 63). Felizmente, quando Lygia acordou, viu o céu limpo, e o avião pronto para o pouso. No Palácio, só a imprensa os aguardava; o ministro não os recebeu, mas eles também não foram presos - a conspiração fora desfeita, como anunciava o irmão Sol no céu de Brasília. TELLES, Lygia F. Conspiração de Nuvens. Rio de Janeiro: Rocco, 2007, p. 59-65.
}

${ }^{103}$ WILLIAMS, Tennessee. Sweet bird of youth/ Rose Tatoo/ Night of Iguana. New York: Signet, 1992. 
tempo diante de si'. Já Heavenly, contaminada com uma doença venérea pelo namorado da adolescência, algum tempo antes de sua volta definitiva, devido a complicações, fica estéril. Chance Wayne, no entanto, não consegue o apoio de Alexandra e acaba sendo castrado pelos capangas de Boss Finley, pai de Heavenly e político influente na pequena cidade onde moram, como vingança pelo 'mal' que o gigolô fizera a sua filha.

Apesar do evidente paralelismo entre as personagens de Alexandra e Rosa e, em menor medida, de Chance e Diogo, não se pode esquecer que todas as personagens da peça de Williams recordam sua juventude e, com tristeza, arrependem-se de todas as chances que perderam - o tempo, a beleza, os sonhos - enfim, o paraíso perdido que eles nunca mais conseguirão recuperar ${ }^{104}$. Nesse sentido é que a peça mantém ironicamente o diálogo intertextual com a 'tragédia' pessoal de Rosa, revivida ao longo de todo o romance, até o episódio em que se dá seu 'renascimento', quando percebe a impossibilidade de capturar o pássaro da juventude, com sua beleza e inocência, levado pelo tempo. Por essa razão, é sintomático que Rosa e Alexandra desempenhem o mesmo papel: o de atriz. No entanto, o fim trágico de Doce Pássaro não se repete com Rosa, uma vez que sua suposta metamorfose ao final do romance, provocada pelo enfrentamento de seus inimigos, o sol e o tempo, permite-lhe ao menos vislumbrar uma possibilidade de vida com seu antigo gigolô, Diogo. Atuar em Doce Pássaro da Juventude teria, para a protagonista, então, um duplo sentido: com essa peça, ela não projetaria seus recônditos conflitos nas personagens, mas sim, encenaria, dentro dos limites do texto, sua própria história, enfrentando os medos da velhice, da solidão e do esquecimento do público ao encenar justamente sua 'tragédia' pessoal. Deste modo, seria inteira no palco e na vida, pois faria o movimento contrário ao que realizou durante toda sua carreira como atriz: ao invés de reviver/espelhar dilemas de seu passado nas situações dramáticas encenadas no palco, desta vez, ela levaria sua história pregressa para o teatro, representando a si mesma e, assim, livrar-se-ia dos fantasmas do passado para viver o momento presente em nome de um futuro em aberto- o que fica no plano da suposição.

Assim, pode-se dizer que em As Horas Nuas prevalece um tipo especial de representação, semelhante à estrutura de caixas chinesas: para encontrar a verdadeira Rosa, na menor e mais recôndita das embalagens, é necessário que se desembrulhe caixa a caixa,

\footnotetext{
${ }^{104}$ Sandra Almeida também observa que o enredo de Doce Pássaro da Juventude é paralelo à história pessoal de Rosa, mas atribui esse paralelismo ao tema da castração presente, segundo a autora, como tema da peça de Williams e característica da protagonista e de seu gato no romance de Telles. ALMEIDA, Sandra R.G. Castration and melancholia in Lygia Fagundes Telles' As Horas Nuas. Disponível em: $<$ http://tell.fll.purdue.edu/RLA-Archive/1991/Spanish-html/Almeida,Sandra.htm> Acesso em: 10 abr. 2007.
} 
começando pelas maiores e mais aparentes, camada a camada, até chegar ao fundo, pois as aparências ocultam sua verdadeira persona. Trata-se, portanto, da representação da representação da protagonista, de uma personagem repleta de personagens, assim como o romance está marcado pelo diálogo com obras da literatura mundial e também de referências a outros textos de Lygia Fagundes Telles; nesse sentido, a ironia fina do gato Rahul é cortante quando afirma não saber onde se encontra a 'natureza mais profunda' da atriz, frase normalmente enunciada por ela em entrevistas, cujos leitores tinham acesso a mais uma de suas representações: a Rosa Ambrósio alheia às intrigas e às futilidades, posando de 'artista solitária'. No sentido aqui exposto, se a referência à personagem pela expressão Rosa, Rosae corrobora, em primeira instância, a tentativa da atriz de chegar ao âmago, de buscar algo primordial, reforçada pelo uso do latim, sua declinação é mais um indicativo de que ela pode ter sido várias, revestida de papéis, de acordo com a exigência de cada situação, uma vez que em latim a atividade de declinação de um nome significa enunciar os diferentes modos que ele assume de acordo com as funções que desempenha na oração ${ }^{105}$. Assim, antes de se constituir em "objeto da fala de outras personagens, (...) receptor destas falas ou mero adjunto circunstancial" "106, é como sujeito, portanto, que a atriz pode ter sido uma única Rosa, no singular, mas também mais do que uma, Rosas, no plural.

De modo geral, oscilando seu posicionamento no jogo de exposição e ocultamento, é possível que Rosa se desembrulhe e dispa suas máscaras, uma a uma para o leitor, revelando, numa trajetória pessoal, traços de uma trajetória coletiva da mulher em busca de sua autorrepresentação. $\mathrm{O}$ trabalho de linguagem habilmente articulado tem na intertextualidade, que em nenhum momento é gratuita, um fator primordial, que revela o nível da complexidade da representação que a atriz faz de si própria e dos outros, pois está completamente imbricada no repertório conhecido e/ou encenado de seu mundo profissional, o que permite compreender por que, só do palco, não fugira; por que, só como atriz ela tenha conseguido ser inteira. É a analista de Rosa, Ananta Medrado, quem dá as primeiras pistas sobre o fato de que a atriz misturava 'seu próprio repertório' ao das peças que outrora encenara num caos semelhante ao fundo da sacola em que a atriz carregava objetos de uso pessoal, medicamentos, agenda, chaveiro, mas é Rahul, na posição de espelho verdadeiro de Rosa, quem reflete sobre essa condição: "Impregnou-se tanto dos papéis que representou que facilmente passa de um papel para outro- fragmentos que vai juntando e emendando nas

\footnotetext{
105 RONÁI, Paulo. Curso Básico de Latim Gradus Primus. v.1.10. ed. São Paulo: Cultrix, 1996, p.32.

${ }^{106}$ VILLAÇA, Nízia. O olhar Barroco. In: Paradoxos do pós-moderno: sujeito \& ficção. Op.cit., p. 136.
} 
raízes, dependendo da conveniência" (HN, p. 103-grifo meu). Melhor dizendo: quando ela mergulha em seu mundo interior, com sua noção de real, tão caótico quanto a realidade circundante, seu monólogo já vem filtrado por todas as representações que fizera no palco, onde ela realmente foi inteira, uma vez que a atividade como atriz consistia em representação pura, pois encenava uma única personagem a cada vez. Com o uso da intertextualidade revela-se um importante aspecto da poética da escritora, a saber, a marca deixada por textos e autores consagrados por crítica e público, em seu projeto de criação literária, na medida em que delimita e insere-se num amplo espaço cultural, hegemonicamente masculino, do qual também se apropria para a construção de suas próprias personagens. Unidos às raízes de suas personagens, encontram-se, acionados, fragmentos de outras leituras, de outras personagens, que colaboram com a escritora no processo de construção das próprias personagens, na representação que a elas deseja dar. Por essa razão, as peças teatrais mencionadas e suas personagens constituem-se, respectivamente, em espelhos e máscaras no jogo narrativo de As Horas Nuas.

É justamente nesse aspecto que a escolha das peças anteriormente mencionadas, no tocante à questão das técnicas de representação calcadas no fluxo de consciência, no monólogo e nas operações de lembrança e esquecimento, está ligada especialmente à seleção das personagens femininas que participam do jogo da criação literária de Lygia Fagundes Telles neste romance. Trata-se das representações de figuras femininas que essas personagens encerram, as quais aludem a diversas idades (adolescentes, jovens, maduras e idosas), historicamente localizadas em contextos diferentes, mas que enfrentam a mesma condição de sujeição. Na escolha dos 'papéis' desempenhados por Rosa no teatro, feita pela autora de As Horas Nuas, figuram 'modelos' de personagens femininas que, embora revelem sentimentos de tempo e de lugar distintos, assemelham-se por se constituírem em papéis representativos das várias etapas da tentativa da mulher de se tornar sujeito, de ter direito à sua própria história - trajetória paralela à vivida por Rosa Ambrósio. Por essa razão, tais personagens percorrem caminhos que partem da submissão e da obediência à figura masculina, encontram na loucura e no suicídio o refúgio ou a punição por ousarem ser, como Ofélia; ou, então se rebelam, mostrando a face indomável, por trás da qual se esconde o medo de ser ou a 'incapacidade' de ser sem a presença de um marido ou pai, como Amanda; ou conseguem dar visibilidade aos desejos recônditos a partir de pequenas 'desobediências', apenas no plano da memória ou da alucinação como Alaíde; ou, ainda, o sofrimento da mulher, outrora uma celebridade, descida do pedestal com a chegada da velhice, como Alexandra Del Lago. Desse modo, a escritora opera com representações tradicionais da figura feminina, como a velha 
dicotomia anjo x demônio, mas delas faz uso próprio ao utilizar-se de alguns aspectos cruciais deixados na memória por essas representações para retratar, em sua protagonista e nos personagens com quem esta contracena, as transformações do papel social da mulher.

A escritora, ao se utilizar do diálogo intertextual com o teatro, descortina, a partir de personagens femininas marcantes escritas por famosos dramaturgós, a encenação de uma possível história da sujeição da mulher pelo patriarcado e de suas tentativas de rompimento com essa estrutura repressora - os entraves à sua emancipação, o que houve quando a figura feminina abandonou o espaço privado da casa em favor do espaço público, e como seu olhar retrospectivo permite verificar os erros e acertos da permanência em um ou outro espaço, na difícil arte de harmonizar a convivência em ambos. Além dessas representações, Lygia insere outras identidades femininas no romance, como Ananta, Cordélia e Dionísia, em contraponto com as figuras de tia Ana, tia Lucinda e a mãe de Rosa Ambrósio, como forma de "reconhecimento de que a mulher brasileira - mesmo a mulher burguesa - é na verdade muitas mulheres, com diferentes valores culturais, diferentes perfis ideológicos e psicológicos(...) ${ }^{\natural 107}$, as quais serão analisadas ao longo dos próximos capítulos.

No que concerne especificamente à protagonista, a busca de uma identidade própria, diante das dificuldades de aceitação do fracasso das relações familiares e do envelhecimento, gera sofrimento e culpa: como deveria ser a identidade de uma 'nova mulher', porém idosa, excluída, quando a manutenção das relações de aparência é prerrogativa da sociedade em que vive, mas as marcas inscritas no corpo tornam essa mesma relação impossível? Essa á a busca de Rosa.

${ }^{107}$ PINTO, Cristina Ferreira. Consciência feminista/identidade feminina: relações entre mulheres na obra de Lygia Fagundes Telles. In: SHARPE, Peggy. (org.) Entre resistir e identificar-se. Florianópolis: Editora Mulheres, p. 70 - grifo meu. 
Qetrato

\& $u$ não tinha este rosto de hoje, assim calmo, assim triste, assim magro, nem estes othos tã̄o vazios, nem o lábio amargo.

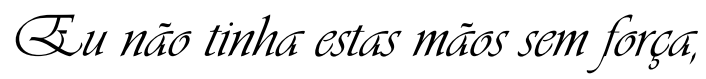
tẫo paradas e frias e mortas;

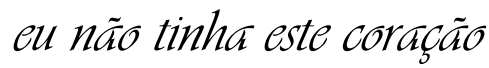
que nem se mostra.

\& $u$ nãa dei por esta mudanga, tão simples, tão centa, tấo fácill

- Em que espelho ficou perdida a minha face?

(Eecilia Cheireles: oflor de Doemas) 


\section{CONTRACENANDO NA INTIMIDADE}

a produção literária brasileira, publicada a partir de 1990, Regina
Dalcastagnè observa que há uma espécie de 'retração' na representação feminina feita tanto por homens quanto por mulheres. No caso das escritoras, que aqui é o ponto que interessa mais de perto, há uma predominância na criação de personagens femininas encarceradas no espaço da casa, normalmente vazia, em que permanecem "sem contato com pessoas, sem trabalhar", sem cuidar dos filhos, mas 'remoendo suas mágoas, as traições do marido ou do amante', em “profundos conflitos existenciais"108. Segundo essa perspectiva, a mulher está sendo representada, pelas próprias escritoras, como "simples objeto desejante" 109 . Nas obras de escritoras brasileiras mais jovens permanece implícita o que Dalcastagnè considera "a antiquada ideia de que a realização amorosa - portanto, na esfera privada - é 'a' ambição de toda a mulher, sua frustração anulando a possibilidade de quaisquer outras conquistas." 110

Essas considerações, em um primeiro olhar, parecem encaixar-se perfeitamente à protagonista do último romance de Telles: solitária em seu apartamento, com a presença de Rahul e de Dionísia, seres que pouco significado têm para Rosa, ela se encontra apartada do mundo do trabalho, recordando a infância e os bons e maus momentos vividos com o marido e com o amante, a insatisfação com o próprio corpo e com a filha alienada. Entretanto, há um diferencial importante entre a produção destacada por Dalcastagnè e As Horas Nuas, pois este último apresenta uma gama de personagens femininas diversas que revelam não mais as consequências, para a mulher e para a sociedade, de sua permanência no âmbito da esfera privada, principalmente no que toca à condição da mulher burguesa, mas os efeitos de sua saída do ambiente doméstico e seu ingresso no mundo tido como do 'homem'. Em As Horas Nuas, Lygia, como escritora, realiza um movimento que não asfixia a protagonista no espaço da 'casa', mas a traz de volta para esse mesmo local, que se configura como ambiente historicamente propício à reflexão feminina, depois de suas incursões no espaço público, a fim de fazê-la questionar os rumos por ela tomados ao longo de sua vida adulta. Nos limites

\footnotetext{
${ }^{108}$ DALCASTAGNÈ, Regina. A personagem feminina na narrativa brasileira dos anos 90. In: PIRES, Maria Isabel E. (org.). Formas e dilemas da representação da mulher na literatura contemporânea. Op.cit., p. 102.

${ }^{109}$ Ibid., p.102.

${ }^{110}$ Ibid., p. 103.
} 
do monólogo interior de Rosa, o amor aparece não como sua única ambição, mas sim como mais uma delas. Para Gilles Lipovetsky,

\begin{abstract}
Enquanto vetor de afirmação identitária e de paixão que já não impede a abertura para uma vida social autônoma, o apego privilegiado das mulheres ao amor não pode ser confundido com uma remanência anacrônica condenada a ser esmagada pelo rolo compressor da inspeção igualitária. Porque é a partir do próprio interior da cultura moderna da autonomia e de seu apelo a uma vida livre, intensa, personalizada que se prolonga a valorização feminina do amor, a assimetria homem-mulher em relação ao amor tem mais possibilidade de perdurar do que se desfazer. ${ }^{111}$
\end{abstract}

De modo diferente das personagens femininas confinadas de Clarice Lispector, por exemplo, que entre os movimentos de saída à rua e de volta à casa experimentam a revelação de sua alienação no instante fugidio ${ }^{112}$, Lygia, como escritora, discute aspectos positivos e negativos oriundos de algumas conquistas femininas fora do lar quando suas personagens confinam-se por vontade própria no espaço da casa depois daquela 'saída'. Nada mais intrigante para quem se dedica ao estudo da produção literária feita por mulheres no Brasil quando essa matéria, por si só já rica de representação, vem associada com as 'transformações da intimidade', no que concerne a dois aspectos que na prosa de Telles se entrecruzam: as mudanças ocorridas no interior de um modelo de família específico, como o burguês, e as novas relações que a mulher estabelece com o corpo, em decadência, com a chegada da velhice.

A escritora paulistana consegue captar esses dois traços referentes a transformações que normalmente ficam um pouco ofuscadas diante de outros temas que têm sido alvo da produção literária contemporânea como um todo, a qual formaliza esteticamente a experiência brasileira da violência urbana, da corrupção, das desigualdades sociais, matérias que apresentam grande visibilidade e, até mesmo, sentido de urgência. No entanto, os temas tratados por Lygia em seu último romance, embora tangenciem a degradação da urbanidade e da civilidade, igualmente se constituem em matéria geradora de angústia e insegurança para o indivíduo das grandes metrópoles e das cidades interioranas. Esse indivíduo nem sempre encontra no reduto familiar a aura de proteção, o afeto, o diálogo tão necessários para seu fortalecimento diante das mais diversas degradações e 'necessidades' impostas pelos novos

\footnotetext{
${ }^{111}$ LIPOVETSKY, Gilles. A terceira mulher. Op.cit.,p. 50.

112 CHIAPPINI, Ligia. Mulheres, galinhas e mendigos: Clarice Lispector, contos em confronto. In: SUSSEKIND, Flora; DIAS, Tânia; AZEVEDO, Carlito (orgs.). Vozes Femininas: gênero, mediações e práticas da escrita. Rio de Janeiro: 7 Letras: Fund. Casa Rui Barbosa, 2003, p. 436.
} 
padrões da vida moderna, situações às quais os seres estão constantemente expostos dentro e fora de casa, através das imagens veiculadas pelas revistas, pela televisão e, recentemente, pela internet.

A decadência do modelo de família burguesa tem sido reconhecida por críticos e pesquisadores em inúmeros artigos, ensaios e trabalhos acadêmicos como um dos temas centrais na obra de Lygia Fagundes Telles. Parte de seus contos e todos os seus romances focalizam núcleos familiares desestruturados, em que a incomunicabilidade e a solidão dão a tônica nos relacionamentos entre casais, e a ausência paterna na infância ou na adolescência e, raras vezes, a materna- é quase sempre o elemento que desencadeia o conflito vivido pelas personagens, normalmente femininas, na vida adulta. É interessante notar também que, se os primeiros trabalhos de Lygia tinham como protagonistas comuns, em especial, figuras femininas adolescentes ou jovens - mais evidentes em seus três primeiros romances e em muitos de seus contos - a partir de meados da década de 70 , personagens femininas na faixa etária a partir dos 45 anos passam a fazer parte de suas ficções de modo mais intenso, o que não significa dizer que as personagens jovens desapareceram de seus contos e de As Horas Nuas. Isso revela que, à medida que a própria escritora foi envelhecendo, sua perspectiva no tratamento das personagens também sofreu alterações. Esses temas são desenvolvidos por Telles, em maior ou menor escala, nos contos "Senhor Diretor", "Boa Noite, Maria", "Você não acha que esfriou?", “A ceia”, "Um chá bem forte e três xícaras” e "Apenas um saxofone”.

O tom memorialístico, certa 'nostalgia do passado', bem apontada por Suênio Campos de Lucena ${ }^{113}$, surge como parte da experiência da escritora que integra de modo vivo sua 'ficção giratória', para usar a expressão de Fábio Lucas ${ }^{114}$. Assim, dentro de sua produção literária, é possível apontar o desenvolvimento de uma espécie de núcleo temático - a questão do envelhecimento feminino-, normalmente associada à reflexão sobre as mudanças nas relações familiares, nos costumes de uma época, na nostalgia da juventude, no sofrimento gerado pelas mudanças no corpo e no reconhecimento da posição marginal à qual a personagem feminina na 'idade da madureza' é relegada. De certo modo, as situações humanas retratadas mais recentemente do ponto de vista da mulher que envelhece na obra de Lygia filiam-se a temas semelhantes desenvolvidos nos textos de outras escritoras, como Clarice Lispector, em "Feliz Aniversário", Nélida Piñon em "I love my husband”, Adélia Prado em Páscoa, Cecília Meirelles em "Retrato" ou Hilda Hilst em A obscena senhora D. Mais

\footnotetext{
${ }^{113}$ LUCENA, Suênio Campos de. Esquecimento e lembrança em Lygia Fagundes Telles. Op.cit., passim.

${ }^{114}$ LUCAS, Fábio. A Ficção giratória de Lygia Fagundes Telles. Cult - Revista Brasileira de Literatura, São Paulo, ano 2, n. 23, p. 12-15, jun. 1999.
} 
contemporaneamente, Doris Lessing, em Amor, de novo, também se dedicou a essa temática, 'coincidentemente' quando se encontrava na mesma faixa etária de sua personagem Sarah, assim como Lygia em relação à Rosa Ambrósio.

Como mostrada no capítulo anterior, a problemática da protagonista de As Horas Nuas é elaborada literariamente a partir de elementos de mediação e de construção de personagens bastante diferentes se comparados aos trabalhos anteriores da escritora. As técnicas de representação e o aproveitamento de situações envolvem não só personagens das peças teatrais mundialmente conhecidas e mencionadas pela protagonista, mas também outras personagens criadas pela escritora ao longo de sua vasta obra, num esforço contínuo de aprimoramento de sua criação literária. Neste capítulo, analiso como os 'atores' com os quais Rosa contracena na intimidade, segundo o ponto de vista da atriz, mas também de Rahul, funcionam como pretextos narrativos para se discutir a posição da atriz com relação ao seu corpo envelhecido e as marcas de gênero ${ }^{115}$ que especificam as representações do masculino e do feminino no âmbito familiar e social. Em seu monólogo quase tragicômico, ou nas ácidas revelações de Rahul, vicejam indícios que ajudam a reconstituir o relacionamento da atriz com os outros integrantes de sua família, a qual se distancia do modelo patriarcal no qual o pai é o centro do poder de decisão e a mãe, um ser submisso. Na primeira parte, focalizarei a relação da protagonista com seu próprio corpo e com as figuras femininas de Dionísia e Cordélia; na segunda, a análise centralizar-se-á nas personagens masculinas de Gregório e Diogo.

\subsection{Espelho, espelho meu, existe alguém mais narcisista do que eu?}

\subsubsection{A atriz em busca do espelho}

(...) Tantos espelhos. Mas só agora me vejo, uma frágil mulher cheia de carências e aparências, dobrando o Cabo da Boa Esperança, já nem sei que Cabo é esse, era a mamãe que falava nisso mas deve ter alguma relação com a velhice, ô! meu Pai, que palavra desprezível.

Prefiro falar em madureza. Idade da madureza (...). (HN, p. 12)

\footnotetext{
115 Mais uma vez, é importante ressaltar que, neste estudo, o termo gênero é utilizado em consonância com a orientação do discurso feminista, no sentido de revelar o significado social, cultural e psicológico imposto sobre a identidade sexual, o que permite discutir a questão não apenas no que se refere à mulher, mas também ao homem. (Cf. FUNCK, Susana B. Da questão da mulher à questão do gênero. In: FUNCK, S.B. (org.) Trocando idéias sobre mulher e literatura. Florianópolis:UFSC, 1994, p. 17-22)
} 
Rosa Ambrósio distancia-se da antiga representação de mulheres idosas, de nossas avós, que pareciam encarar com mais naturalidade seus cabelos brancos, sua face enrugada e a imagem de seu corpo aparentemente desprovido de sensualidade/sexualidade. Muito menos é tida como detentora de uma sabedoria a ser transmitida às futuras gerações, pois a protagonista, apesar da vasta cultura, está longe de se constituir, para os mais íntimos, em um repositório de conhecimentos herdados de seus ancestrais, como seu avô Júlio. Ao contrário, para a atriz que afirma não sentir ódio pelo corpo 'traidor', velhice ironicamente torna-se sinônimo de desprezo quando ela experimenta as transformações que fazem seu 'corpo entrar em decadência'. Começa, então, a chorar por 'velharias' e entrega seus dias e noites ao domínio da ebriedade. Além de desprezível, a velhice recebe ainda o atributo de obscena, quando Rosa explica à amiga Lili, que se esforça a todo custo para parecer mais jovem, que aquela fase da vida não deve ser exibida, ou manifesta o desejo de ser cremada, para que não a vejam 'desprevenida'. Rosa tenta mascarar até mesmo a referência à atual faixa etária com a expressão "idade da madureza" ${ }^{116}$, na qual se percebem tanto o resquício da antiga associação de velhice com a ideia de 'sabedoria', de maturidade, quanto com a condição de estar a um passo da deterioração, de 'passar do ponto', como os frutos amadurecidos. Por isso, ela considera a velhice 'a pior das doenças' e jamais revela a verdadeira idade.

O conflito vivido pela atriz consiste em seu despreparo em conviver com as marcas cravadas pelo tempo no corpo outrora jovem, expresso na dificuldade de aceitação de sua nova condição, de mulher prestes a se tornar idosa, graças ao estado de "apoteose mental" em que vivia, segundo Diogo. Antes de se entregar à embriaguez constante, Rosa agarrava-se à exploração dos encantos de sua feminilidade; no presente da narrativa, sente que perdeu o 'âmbar dos lábios', expresso no desaparecimento de dois elementos intimamente ligados à profissão de atriz e à sedução feminina: a piteira feita daquela resina e o batom vermelhodrama. O sofrimento com a condição de mulher na 'terceira idade' é o responsável pelo desencadeamento de pendências, dores e alegrias que desfilam pelo monólogo caótico, alimentado pelas lembranças pertencentes ao passado. $\mathrm{O}$ amante dá a dimensão exata dos temores da protagonista:

- É simples, Rosa, escuta, você está em pânico porque sente que está envelhecendo. Foge do trabalho, das pessoas, vai acabar fugindo de mim. Rosa Ambrósio, como vou fazer entrar nessa cabeça que não existe outra saída, existe? Para escapar da velhice, querida, só morrendo jovem, mas

${ }^{116}$ Como leitora assídua de Carlos Drummond de Andrade, é possível supor que Lygia tenha utilizado a expressão 'Idade da madureza' com base no verso do poema "Campo de Flores", no qual o eu lírico discute o amor no 'tempo da madureza'. 
agora não dá mais. A solução é enfrentar sem fazer bico, de bom humor, se possível. (HN, p. 112)

No discurso de Diogo ("Para escapar da velhice, querida, só morrendo jovem”), ecoa a afirmação de Simone de Beauvoir: "Morrer prematuramente ou envelhecer: não existe outra alternativa" 117 , condição que Rosa tentará aceitar a duras penas. Por essa razão, estar em casa, afastada dos palcos e da mídia, constitui tanto uma maneira de esconder a nova realidade que o corpo anuncia quanto uma tentativa de descobrir sua identidade frente às inúmeras máscaras sobrepostas ao longo de sua vida pessoal e profissional.

As antigas fotografias e o espelho, amigo de outros tempos, duplicam o real e sobrepõem à imagem fantasmática da beleza e da sedução do corpo nu de Rosa, eternizado no quadro feito por um pintor polonês quando a protagonista ainda era jovem, a figura evitada pela atriz, captada nas diversas molduras espalhadas em seu apartamento, que guardam, na película refletora, o verdadeiro retrato de Rosa Ambrósio. E aqui um diálogo com o conhecido romance de Oscar Wilde é inevitável: Rosa, como Dorian Gray, teme as consequências do envelhecimento e deseja, a seu modo, parar o tempo. Essa tentativa ocorre quando a protagonista vive, na tensão emocional existente nos momentos lembrados e na constatação das novas configurações corporais, uma duração temporal intensa, cujo ritmo é retardado; as ações recordadas exprimem com a mesma lentidão da extensão temporal a vida interior de Rosa, no desdobramento de pequenos detalhes apreendidos no plano da memória ou diante do espelho. O retrato de Dorian Gray transforma-se no duplo do homem cujo corpo permanece jovem; em contrapartida ao original, é a imagem do quadro que sofre a degradação física e moral e projeta a corrupção de sua alma, espelho capaz de refletir a figura nefasta em que o doce Dorian se transformou. Mais que desejar 'ressuscitar' jovem como sua imagem naquele retrato, reconhecida anos mais tarde por Diogo, Rosa, ao contrário, anseia as experiências românticas e ingênuas que aquela fase da vida tem como prerrogativa - um modo de se afastar da representação da imagem monstruosa que realiza de si mesma a partir do momento que cedeu aos impulsos fáusticos do prazer, da beleza e do dinheiro em abundância.

Na protagonista, o desejo de definir seu antigo eu como sendo o eu que ela continua a ser afirma, como diria Simone de Beauvoir, sua solidariedade com a própria juventude, expressa na essência imutável que ela tenta impor às degradações da senescência e que a

\footnotetext{
${ }^{117}$ BEAUVOIR, Simone de. A velhice: as relações com o mundo. V. 2. Tradução Heloysa de Lima Dantas. São Paulo: Difusão Européia do livro, 1970, p.7.
} 
descreve para si mesma como aquela que um dia fora e que nela sobrevive ${ }^{118}$. Por isso, o sofrimento da protagonista se dá quando o reflexo no espelho, seu duplo, não revela mais a personagem que Rosa Ambrósio mais valoriza e na qual continua a se reconhecer: a mulher e a atriz jovem, bela e cortejada. A razão para esse reconhecimento deve-se, para Beauvoir, ao fato de que a pessoa idosa sente-se velha através dos outros, mesmo sem ter experimentado grandes mudanças, uma vez que interiormente, ela não adere ao rótulo que lhe aplicam ${ }^{119}$. No entanto, a sensação de 'corpo em declínio', reforçada pelos efeitos do climatério já distante, é mencionada por vezes pela atriz. A menopausa funciona como 'rito de passagem' associado, em grande parte da cultura ocidental, à doença, à estagnação do corpo da mulher que, impossibilitada de gerar, graças às flutuações hormonais que levam seu sistema biológico a 'falhar', tem seu processo de 'produtividade' interrompido ${ }^{120}$. Essa passagem para o 'reino das sombras' faz a sexualidade sofrer um deslocamento entre liberação, culpabilidade e rejeição ${ }^{121}$, cujo sintoma mais evidente se manifesta na protagonista na metáfora da substituição gradativa das "camisolas sensuais das noites sensuais" por outras mais quentes, 'de velha', como a protagonista alude ironicamente. É, portanto, “menos do próprio corpo que provêm os incômodos da mulher que da consciência angustiada que tem deles. O drama moral inicia-se antes que os fenômenos fisiológicos se declarem e termina quando eles já de há muito desapareceram." 122

Nas 'andanças' pelo corpo embriagado de Rosa, Rahul vai tecendo outro retrato da atriz, menos exigente e repleto de comiseração quando manifesta a preocupação com sua dona. Embora note que a pele de Rosa se 'ressentiu', na ausência dos costumeiros banhos de sol, das massagens, dos 'quilos de cremes' e dos banhos, o gato reconhece que a atriz conseguiu seduzir o tempo assim como as pessoas, pois seu perfil "resiste como nas medalhas" (HN, p.92): sua pele permanece tenra, não escureceu nem enrijeceu, "mas continua uma pétala intacta", assim como os bicos dos seios, rosados, lembram uma "pétala pálida'(HN, p.103). Com a chegada da velhice, a visão que a atriz apresenta sobre seu próprio corpo é a da Rosa Despetalada, como atesta o uso que passa a fazer de um vocabulário

\footnotetext{
${ }^{118}$ BEAUVOIR, Simone de. A velhice: as relações com o mundo. V.2. Op.cit., p. 99.

${ }^{119}$ Ibid.,p. 17.

${ }^{120}$ BARBOSA, Maria J. S. Corredores, labirintos e ritos de passagem para a idade avançada. In: Passo e Compasso: nos ritmos do envelhecer. Porto alegre: EDIPUCRS, 2003, p.166. (org.).

${ }^{121}$ SWAIN, Tânia N. Velha? Eu? Autorretrato de uma feminista. In: Labrys- estudos feministas, n.4, ago.-dez. 2003. Disponível em: <http://vsites.unb.br/ih/his/gefem/labrys4/textos/anahi1.htm> Acesso em: 21 dez. 2009.

${ }^{122}$ BEAUVOIR, Simone de. O segundo sexo. Tradução Sérgio Milliet. 2. ed. Rio e Janeiro: Nova Fronteira, 2009, p. 757-758.
} 
específico, no qual figuram adjetivos que expressam sua sensação de cansaço, culpa e desejo de evasão, como 'exausta', 'esvaída', 'esbagaçada'. Na beleza dessa Rosa, cujo nome é emprestado da flor cantada por poetas como Pierre de Ronsard e remete à sua efêmera duração ${ }^{123}$, paradoxalmente a própria atriz supunha estar o néctar da imortalidade ${ }^{124}$ com o qual alimentava seu caráter narcisista e o desejo dos homens, como seu sobrenome, Ambrósio, sugere. A chegada da terceira idade torna, então, a atriz consciente de que a fonte de onde jorra esse néctar seca, como seu último nome de família, Fonseca ${ }^{125}$, indica.

Como sabemos, o corpo feminino encontra-se submetido a coerções estéticas mais regulares e geradoras de ansiedade que o masculino. Neste, os cabelos brancos e as rugas não constituem uma ameaça à virilidade, mas revestem de 'charme' as marcas da 'experiência'; no corpo da mulher, aqueles mesmos sinais do envelhecimento são responsáveis pela perda da graça e do viço femininos. Um exemplo interessante em As Horas Nuas é o apreço que Rosa tem pelas mãos, as quais, segundo seu amante, são 'as delatoras' da idade; por isso, a atriz seguia seus conselhos, aplicando inúmeros cremes nessas mãos sem sardas e usando esmaltes que não chamassem a atenção para as poucas marcas da passagem do tempo nelas contidas: "tom de verniz rosa-antigo para uma rosa-antiga" (HN, p. 99). Batizado pelo gato com a expressão 'operação-tintura', o tingimento dos pêlos pubianos, seguido do das raízes brancas dos cabelos das têmporas, entretanto, era a representação mais dramática empreendida pela atriz em sua luta para 'seduzir o tempo' e camuflar a idade diante do amante, quando ele ainda vivia com Rosa. A cena, assistida com exclusividade por Rahul - o único que não pode denunciar as atitudes tomadas pela protagonista na tentativa de reverter os efeitos do tempo ocorre no banheiro, sob o barulho da água do chuveiro, ligado propositadamente para acobertar seu monólogo, mas também ocultar os sons provindos dos frascos dispostos sobre a pia. A presença do espelho de formato oval que lembra os espelhos dos camarins das estrelas teatrais, repletos de pequenas luzes cravadas ao redor, condensa as marcas da vida profissional arraigadas em Rosa e trazidas para o ambiente doméstico: o amor narcísico pela própria imagem. A figura da protagonista nele refletida lembra, para o gato, o rosto de um palhaço, com a 'cabeleira esgrouvinhada', de onde provém o fio de tintura a escorrer sobre a

${ }^{123}$ XAVIER, Elódia. O corpo envelhecido. In: Que corpo é esse? O corpo no imaginário feminino. Florianópolis: Ed. Mulheres, 2007, p. 93.

${ }^{124} \mathrm{Na}$ mitologia clássica, a ambrosia, o néctar da imortalidade, era dada aos deuses Apolo e Ártemis como alimento.

${ }^{125}$ Segundo Guérios, Fonseca originou-se do sobrenome português Fonte Seca. GUÉRIOS, Prof. Rosário F. M. Nomes e sobrenomes - Tudo o que você gostaria de saber e não lhe contaram: Dicionário Etimológico. 4. ed. São Paulo: Ave-Maria Edições, 1994, p. 159. 
máscara branca de creme que cobre o rosto da atriz. Tal caracterização de Rosa é reveladora do ponto de vista do gato como testemunha da passagem dos tempos: "Luta e castigo. Isso das mulheres bonitas e dos homossexuais sofrerem dobrado quando começa a decadência. Seres destinados à destruição como todos nós mas com a mesma obsessão da beleza. $\mathrm{O}$ culto do corpo.” (HN, p. 139-140)

O momento em que Rosa passa pelo início do processo de envelhecimento coincide com um período de excessiva valorização da sexualidade e do corpo magro, jovem e saudável, já iniciada nas primeiras décadas do século XX. Com a construção gradativa de uma economia moderna, principalmente a partir dos anos 1930, com maior intensidade a partir da década de 50, o Brasil incorporou padrões de consumo e de produção semelhantes aos dos países desenvolvidos. Dentre os níveis de progresso alcançado com a instalação ou criação de indústrias automobilísticas, petroquímicas, siderúrgicas, com a construção de hidrelétricas, de rodovias, com o consumo de eletrodomésticos e de alimentos industrializados, um outro tipo de 'necessidade' passa a conviver e a se impor principalmente para as mulheres, a partir da popularização de produtos de higiene e de beleza. A instalação progressiva de grandes lojas no país, trazendo roupas e cosméticos utilizados por mulheres 'estrangeiras', a fotografia, a imprensa e, principalmente, o cinema deram sua considerável contribuição no sentido de divulgar padrões femininos a serem 'consumidos', inicialmente para as mulheres ricas, os quais passaram a reger a apresentação pessoal da mulher, impondo ideais estéticos que mudam conforme as condições de produção e veiculação da imagem feminina. Mary del Priore esclarece que, desde essa época, o desenvolvimento da estética cinematográfica, calcada nas figuras de atrizes de rostos jovens, maliciosos e sensuais, contribuiu para a construção de um modelo de beleza que 'baniu de cena' a mulher velha.

Se até o século XIX matronas pesadas e vestidas de negro enfeitavam álbuns de família e retratos a óleo, nas salas de jantar das casas patrícias, no século $\mathrm{XX}$, elas tendem a desaparecer da vida pública. Envelhecer começa a ser associado à perda de prestígio e ao afastamento do convívio social. ${ }^{126}$

Afastada do mundo das aparências e das ilusões de que participara na atuação como atriz, Rosa é capaz de perceber essa relação aprisionante entre imagem e idade quando atinge o patamar de mulher mais idosa e gradativamente exclui-se e é excluída da atividade profissional: "Só se fala na decadência dos usos, decadência dos costumes, está na moda a

\footnotetext{
${ }^{126}$ DEL PRIORE, Mary. Corpo a corpo com a mulher: pequena história das transformações do corpo feminino no Brasil. São Paulo: Editora SENAC São Paulo, 2000, p.75. (Série Ponto Futuro 2)
} 
decadência. Sou uma atriz decadente, logo, estou no auge" (HN, p. 20). Por isso, a atriz percebe-se marginalizada, "uma bêbada podre num mundo podre" (HN, p. 19), degradado, em que a educação e a cultura são substituídas, com mais veemência, pelas "imagens" de prazer e de sucesso produzidas pelos meios de comunicação de massa. A supervalorização do corpo e da sensualidade é questionada por Rosa ao longo de todo o romance, quando ela se recorda, por exemplo, que houve um tempo em que o sexo não esteve na moda, ou quando a velha atriz percebe, indignada, no discurso publicitário, a inexistência de comerciais de geladeira que a ele não remetam. Por isso, em sua crítica à sociedade contemporânea e às formas mais cabais de produção e de consumo, a protagonista revela a atitude assumida por meios publicitários que atuam de modo a personalizar os objetos - dos quais, a mulher é mais um - e torná-los atraentes, utilizando normalmente, como recurso, uma boa dose de erotismo.

A rua suja, o teatro sujo. A televisão. Começaram agora a usar crianças nos
anúncios de máquinas, sorvetes, refrigerantes. As menininhas fazendo gestos
e esgares sensuais de putas. Não tenho nada contra as putas mas não é um
exagero tanta lição de putaria? O reino da vulgaridade. (HN, p. 19)

O sofrimento de Rosa origina-se, portanto, da percepção da dificuldade de luta contra as prescrições de um 'algoz sem rosto': o do discurso jornalístico e publicitário, da mídia, com seus cartazes na rua e o bombardeio das imagens na televisão ${ }^{127}$, da discrepância entre o olhar que tem de si e o que os outros dela têm. O trágico vivido pela mulher que envelhece, na figura da protagonista, corresponde ao que nas tragédias teatrais "não é mais, então, que uma defasagem entre postulação individual e realidade social e a perda do indivíduo contra uma ordem social vindoura ou advinda" ${ }^{128}$. Nesse sentido, a posição da atriz é semelhante à da velha professora Maria Emília, de "Senhor Diretor". Neste conto, o moralismo da personagem diante das capas de revistas, em que corpos esbeltos exalam sensualidade, vai sendo desconstruído pela narrativa a partir do que seria o esboço de uma carta que a protagonista enviaria ao diretor de um jornal de ampla circulação. Nesta carta que efetivamente não é escrita, à semelhança das memórias de Rosa, revela-se, além de uma evidente crítica à cultura em tempos de globalização, a nostalgia dos velhos e românticos tempos e o desejo sexual latente da personagem, abafado pela ordem patriarcal, que a relegou ao plano da domesticidade e a uma vida insípida, calcada na rígida obediência aos preceitos dos 'bons costumes', em detrimento do prazer e da liberdade de fazer suas próprias escolhas. A posição

\footnotetext{
${ }^{127}$ DEL PRIORE, Mary. Corpo a corpo com a mulher. Op.cit., p. 15.

${ }^{128}$ PAVIS, Patrice. Dicionário de Teatro. São Paulo: Perspectiva, 1999, p. 419.
} 
ambígua de Maria Emília, que ao final do conto fica mais evidente com o sentimento da passagem do tempo, percebido com a chegada da velhice, faz essa mulher solteira refletir sobre o comportamento das novas gerações, como as sucessivas levas de alunas que por ela passaram, e questionar também a condição da mulher atual, discutida em reuniões feministas, como o direito ao aborto, à denúncia de todo tipo de violência, comparando tal condição com a da própria mãe, uma mulher 'antiga' que, durante toda a vida, não obteve nenhum prazer sexual, levando também a filha a temer o sexo. A dolorosa constatação de que talvez seus princípios rígidos não passassem de pura inveja diante da liberdade e da coragem das novas mulheres deixa ainda mais à mostra o retrato de uma mulher duplamente marginalizada pela velhice e pela tradição patriarcal. Rosa Ambrósio, então, pode ser considerada herdeira da mesma nostalgia dos valores do passado que fundamentam a visão de Maria Emília, com a grande diferença de que a atriz teve uma sexualidade ativa com diversos homens e livre acesso a uma vida dinâmica, com todos os recursos capazes de adiar o processo de envelhecimento, graças a sua condição econômica privilegiada, se comparada à da velha professora.

Ambas as personagens têm em comum a indignação com a banalização do sexo e a exibição dos corpos que está calcada, por um lado, na inveja que sentem pela juventude das outras, expressa na metáfora do rio espumejante que avança sobre o já estabelecido, e, por outro, na nostalgia dos tempos em que imperava o mistério, com os prazeres a serem descobertos. A presença concomitante desses dois sentimentos em Maria Emília e em Rosa Ambrósio indica sua formação, em um tempo não muito distante, em que certas partes do corpo feminino constituíram-se em objeto de censura e deveriam ser recobertas, fechadas, ocultadas, assim como a expressão das emoções e os gestos deveriam ser comedidos, 'adequados' à imagem pública da mulher. O rompimento do silêncio do corpo da mulher, conseguido pela nova geração de mulheres que as sucedem, do ponto de vista das protagonistas, ocorre com um certo exagero, na medida em que perpetua a imagem da mulher como espetáculo não mais apenas para os homens, mas sim, para si próprias. À pergunta de Maria Emília - "É proibido envelhecer?"-, os belos corpos rijos, bronzeados e jovens dos anúncios e revistas por ela vistos nas bancas de jornais respondem positivamente.

Com o processo de ressignificação do passado, Rosa revela também, pelo exercício da palavra, antigos valores associados à beleza feminina e que só vêm à tona quando ela sente-se privada de participação do universo no qual vivera até então. Sua profissão como atriz teatral encerra a representação da imagem clássica da estrela que, por sua vez, "é indissociável do 
luxo, das festas, das viagens, das paixões extraordinárias" ${ }^{" 29}$. Desse modo, ao optar pela caracterização de Rosa como atriz teatral que, chegada a velhice, imita o mesmo "climão das antigas estrelas de Hollywood" (HN, p. 113), a escritora também amplifica o sofrimento da protagonista na medida em que esta sente na pele o desdobramento da decadência de sua imagem profissional como idêntica à sua imagem de mulher na intimidade. Para Edgar Morin, a estrela de cinema é "o actor, ou a actriz, que sorve uma parte da substância heróica, quer dizer divinizada e mítica, dos heróis de filme, e que, reciprocamente, enriquece essa substância com o contributo que lhe é próprio" ${ }^{130}$. É importante destacar, no entanto, que, embora tenha se inspirado também no modelo das estrelas de cinema, como atriz dramática, Rosa não vendia apenas a imagem estética de uma belíssima mulher que era objeto de desejo masculino e de inveja feminina, mas também um trabalho de composição. Essa associação entre aparência e talento pode ser observada na recordação de sua atuação na peça $A$ Dama das Camélias, no momento de evocação e atualização do passado na presença de Dionísia:

- Queria ver A Dama das Camélias, lembra? Paguei-lhe o amor, nada lhe devo! ele disse e me atirou as moedas na cara. Ou fichas? Fui uma grande atriz, querida. Não viu essa peça?

- Não.

- Arranquei lágrimas de gente que não chora nem quando morre a mãe, todos urrando de tanto chorar enquanto eu morria podre de beleza, tossindo num lencinho. (HN, p. 162)

Com a progressiva valorização da manequim em detrimento da antiga estrela, a beleza passa a ser pura representação, já não destinada apenas à sedução masculina, mas à das mulheres como consumidoras. Com a estrelização das top models e atrizes televisivas, valoriza-se cada vez mais a beleza e a juventude do corpo magro: “(...) o que antes resultava do talento e do gosto individuais depende, no universo midiático moderno, de um trabalho de profissionais da aparência" ${ }^{\prime 131}$, fonte de sofrimento para Rosona, que já não consegue disputar o mesmo espaço com as beldades massificadas pela mídia. Segundo Giddens, assim como a sexualidade e o eu, hoje o corpo está intensamente impregnado de reflexividade, e o que diferencia as preocupações com a aparência e controle físico atuais das preocupações tidas como tradicionais é que o corpo se torna além de um foco do poder disciplinar, para dizer com Foucault, um "portador visível da auto-identidade, estando cada vez mais integrado nas

\footnotetext{
${ }^{129}$ LIPOVETSKY, Gilles. A terceira mulher. Op.cit., p. 177.

${ }^{130}$ MORIN, Edgar. As estrelas de cinema. Lisboa: Livros Horizonte, 1980, p. 35. (Col. Horizonte de Cinema 5)

${ }^{131}$ LIPOVETSKY, Gilles. A terceira mulher. Op.cit., p. 181.
} 
decisões individuais do estilo de vida"'132. Nesse sentido, a dieta e a 'malhação' em academias especializadas, por exemplo, surgem aparentemente como decisões individuais, mas, na verdade, são condicionadas por todo um aparato midiático que organiza as preferências pessoais, principalmente das mulheres, confirmando, graças à supremacia das imagens, que a “tirania da perfeição física empurrou a mulher não para a busca de uma identidade, mas de uma identificação." 133

A protagonista de As Horas Nuas recorre justamente às atividades físicas como a natação e a 'pedalação', bem como às clínicas de desintoxicação, devido ao consumo de álcool, e até mesmo aos recursos da cirurgia plástica quando se sente disposta a voltar aos palcos, à exibição pública de sua imagem, seja com o objetivo de voltar ao trabalho para encenar novos papéis, talvez mais 'adequados' à sua faixa etária, seja para aguardar a volta de Diogo. Rosa sofre com a falta de identificação de seu corpo agora envelhecido com as imagens que integram a beleza feminina à lógica de mercado: a ditadura da moda e do novo, que auxilia na venda de uma "imagem" de mulher - não como representação mimética, mas sim, como representação de uma imagem da realidade, que a própria Rosa, no auge da beleza, ajudou a criar e da qual também se alimentou na juventude, em escala menos arrebatadora ${ }^{134}$. Diante do sofrimento gerado por acreditar que se distancia da representação do 'belo sexo', afirma que "o corpo é do Diabo porque foi depois que rompi com meu corpo que me aproximei de Deus" (HN, p. 55). Com essa declaração, a protagonista realiza inconscientemente a identificação de seu corpo na juventude com as imagens eróticas demoníacas que caracterizavam a "primeira mulher ou a mulher depreciada", isto é, a representação da figura feminina completamente inferiorizada, afastadas das funções nobres, que vigorou até o século XIX aproximadamente ${ }^{135}$. Aquelas imagens, das quais poderíamos citar as conhecidas expressões 'armadilha do Maligno', 'porta do Diabo', 'raiz do mal', estão associadas aos poderes simbólicos atribuídos às mulheres como figuras misteriosas, maléficas, diabólicas, detentoras de encantos e malícias que se servem da feitiçaria e da magia para estabelecer o caos e a desordem. Essas representações, que só perderam alcance com a progressiva idealização da 'segunda mulher' como 'anjo do lar', o 'belo sexo', educadora dos

\footnotetext{
132 GIDDENS, Anthony. A transformação da intimidade: sexualidade, amor e erotismo nas sociedades modernas. Tradução Magda Lopes. São Paulo: Editora da UNESP, 1993, p. 42.

${ }^{133}$ DEL PRIORE, Mary. Corpo a corpo com a mulher. Op.cit., p. 13.

${ }^{134}$ Os efeitos dessa relação de Rosa com a imprensa voltada para 'o mundo da mulher' é discutida mais detalhadamente no capítulo "Memórias Deslumbrantes".

${ }^{135}$ LIPOVETSKY, Gilles. A terceira mulher. Op.cit., p. 232.
} 
filhos, 'força civilizadora dos costumes', continuam circulando, juntamente com essas últimas, mas foram amenizadas na representação feminina como mulher-mistério, encarnada pelas estrelas de cinema desde o início do século XX até chegar à da 'terceira mulher', que põe fim à lógica de dependência diante do homem ${ }^{136}$. Com o envelhecimento, na visão de Rosa, seus atrativos femininos deixam de funcionar como elementos responsáveis pela sedução e 'derrocada' do sexo oposto; a partir de então, tais atrativos evidenciam os efeitos das expectativas frustradas sobre sua própria beleza com a chegada do que considera $\mathrm{o}$ 'crepúsculo da vida'. Na falsa 'paz sexual' que Rosa admite gozar, recai, na verdade, o peso da vergonha do próprio corpo, tido como impuro, traidor; no momento em que parece acertar as contas com o passado, a atriz oscila entre o prazer e a culpa, sentimentos que se revezam no jogo de expor/ocultar. Isso remete à dificuldade que ela tem de assumir uma posição em que seus desejos mais profundos, na maioria realizados, são postos à prova, mas também pesados, medidos, no processo de revisitação ao passado.

Somente com a chegada da terceira idade é que a atriz compreende seu fracasso na esfera da vida privada e faz uma espécie de 'balanço' de sua 'atuação como esposa e mãe'. Embora tenha sido uma atriz talentosa, estes papéis não foram desempenhados por Rosa com o mesmo glamour. A antiga estrela, enaltecida pelo público no auge da juventude, embora seja uma nova mulher de terceira idade, percebe, pelo exercício da palavra, a prevalência de valores antigos associados à figura da mulher, caracterizados como o 'eterno feminino'. Apesar de tudo, Rosa Ambrósio resiste e não “depõe as armas” por completo. Sua resistência configura-se inicialmente na recusa de papéis mais 'adequados' à sua faixa etária, revelando o desejo profundo de encenar jovens princesas ou mulheres 'extraordinárias', questão intimamente relacionada com o romantismo que caracteriza a personagem. Somente ao final do romance, Rosa parece concordar com a possibilidade de desempenhar o papel de atriz decadente e envelhecida, como vimos, na figura de Alexandra del Lago, de Doce Pássaro da Juventude.

Nesse sentido, não é contraditória a coexistência das imagens da bruxa, associada à velhice e à monstruosidade, e da princesa, ligadas à juventude e à bondade, no monólogo de Rosa Ambrósio, que confluem para sua caracterização como atriz. Entre desistir e resistir, a posição ambígua da protagonista de As Horas Nuas coaduna-se com a discussão da criação de uma imagem feminina baseada em outras imagens, o que, por sua vez, corrobora o jogo da representação no romance que, assim como as personagens encenadas pela protagonista no

\footnotetext{
${ }^{136}$ LIPOVETSKY, Gilles. A terceira mulher. Op.cit., p. 235-236.
} 
teatro, constitui outra máscara a recobrir sua condição de mulher envelhecida em conflito, na busca de uma nova identidade. Trata-se ainda, e acima de tudo, da luta pelo conhecimento e pela autonomia de seu próprio corpo.

\title{
3.1.2. A face negra do espelho
}

\begin{abstract}
A Dionísia que me oferecia leite teve outra vida antes? E que vida foi essa para retornar com a pele negra. E ainda por cima, mulher. Tão devotada a Deus a escrava que pelo visto não é correspondida no seu amor, não sei o que significa neste mundo uma preta pobre. Feia. E um gato sem raça. Castrado e com memória. (HN, p. 126)
\end{abstract}

Mais uma vez é Rahul quem apresenta ao leitor, com maestria, a faceta recôndita de outra personagem que integra a vida de Rosa, adotando, como observador, um ponto de vista onisciente no tocante à sua descrição física e suas atitudes, mas mudando o foco quando age como testemunha, ao tecer considerações sobre o que vê em relação à sua própria condição. Assim, a figura da empregada Dionísia vai sendo delineada nas referências feitas pelo gato, mas também nas realizadas por Rosa, na medida que integra os diálogos com a protagonista e atua como suporte doméstico de seu apartamento.

É ainda Rahul quem oferece a dimensão metódica que dá sentido à vida dessa empregada pobre e negra: "Ao lado da geladeira, dependurou o calendário religioso que tem a estampa colorida do Cristo de coração sangrando. Com cuidado arranca o dia anterior já lido e vivido e vai buscar os óculos para ver de perto o novo dia. (...)" (HN, p. 57-58). Em sua vida disciplinada pelo trabalho, o tempo transcorre naturalmente na metáfora do calendário, um dia após o outro; colhe o dia, alimentando-se da fé em Deus, comportamento plácido que contrasta com o de Rosa Ambrósio, que não aceita a passagem do tempo ${ }^{137}$. Sua visão religiosa do mundo garante inclusive a representação que ela dá aos outros membros da 'constelação ambrosiana': Gregório era um 'santo', não se queixava das dores que o aterrorizavam, e Cordélia, em seu cuidado com um dos homens velhos com quem se relacionava, hospitalizado devido a um derrame, 'fazia caridade'. Com a religião e os hábitos impostos como não mentir nem fumar, Dionísia torna-se triste, segundo a atriz, pois "a virtude é triste". Na casa de Rosa, ela é quem realmente toma as rédeas, cuida da patroa,

137 XAVIER, Elódia. O corpo envelhecido. In: Que corpo é esse? O corpo no imaginário feminino. Florianópolis: Ed. Mulheres, 2007, p. 95. 
preocupa-se com sua alimentação e com seu bem-estar, sugerindo-lhe a tomada de certas atitudes, como a volta aos palcos, por exemplo, para que possa sair do alcoolismo e da depressão:

- A senhora precisa trabalhar de novo, é bom ter um serviço.

- Eles não me querem.

- Por que não? Tem muita gente de idade que trabalha.

- Gente de idade, ah, querida Dionísia. Meu espelho verdadeiro. (HN, p. 52)

Seu nome remete ao deus grego do vinho, Dioniso, associado, como vimos, às práticas orgiásticas e também ao nascimento da tragédia, da comédia e da sátira, personificando o triunfo do instinto. Embora Dionísia perca, por vezes, o estatuto de simples empregada, ganha o de face negra do espelho, no qual Rosa vê o oposto da mulher no auge da carreira e da beleza, funcionando, por essa razão, como seu “espelho verdadeiro". Nesse sentido, aos olhos da atriz, ela representa o estágio atual de sua própria vida, marcado pelo sentimento de exaustão e solidão: Dionísia "afasta-se num andar pesado, ela pisa como o Destino. Saiu da cena" (HN, p. 55). Por outro lado, ela também atua como seu espelho ao representar as condições e situações opostas às vividas por Rosa, isto é, a ausência de quaisquer comportamentos que possam estar associados ao mundo dionisíaco ${ }^{138}$. Nas alpargatas fosforescentes e na fé inabalável de Dionísia, o olhar narcisista da velha atriz reconhece o brilho de Dionísia em comparação com a opacidade de suas próprias mãos; somente o gato, que lhe atribui características também positivas, é quem verdadeiramente enxerga que nos últimos tempos ela não andava 'muito brilhante'. Dionísia apresenta mãos quentes e ásperas, pele rija e tornozelos inchados por enormes varizes, traços que Rosa não tem, marcas 'esculpidas' no corpo pelas responsabilidades e pelo trabalho duro e de longa data como 'escrava'. Se comparado à figura da empregada, o comentário de Rahul sobre Rosa evidencia, nesse jogo de espelhamento, a dimensão clara da face da atriz como oposta à de Dionísia e até mesmo de Gregório: “Gente com caráter envelhece mais depressa, a responsabilidade é um arado cavando sulcos no couro cabeludo. Na face. Mas Rosona é irresponsável, será poupada." (HN, p. 99)

A mesma visão narcisista também faz a protagonista 'esquecer-se' de que Dionísia enfrenta as mesmas condições de viuvez e de chegada à velhice, esta última expressa na réplica da empregada à tentativa da atriz de camuflar o avanço da idade:

\footnotetext{
${ }^{138}$ A ideia de que o nome Dionísia, embora remeta ao deus grego, não apresenta ironicamente qualquer "traço dionisíaco em seu comportamento regrado" também é compartilhada por Vera M. T. Silva em "As Horas Nuas: um jogo de deciframento". In: A ficção intertextual de Lygia Fagundes Telles. Op.cit., p. 56.
} 
- Devo estar com febre. A menopausa, você sabe.

- Mas faz tempo que acabou, a senhora esqueceu? Foi junto comigo. (HN, p. 53- grifos meus)

Pelo sarcasmo desse seu gato memorialista e agnóstico, o leitor descobre que Rosa, na época em que era uma atriz ativa, "na linha dos bonitos, ricos e loucos",

(...) não parava em casa, ou estava representando ou se exibindo em alguma festa. Chegava queixando-se das pessoas, das comidas, estava sempre encarolada quando se estendia no canapé e se abanava com uma ventarola chinesa, ô! Meu Pai. Só para Dionísia confidenciava, Os calores da menopausa, sofro tanto!" (HN, p. 58- grifo meu).

Isso revela, portanto, um dos motivos que explica por que só para a empregada Rosa fazia tal tipo de confidência; mas as angústias vividas pela doméstica no climatério são desconhecidas do leitor. Outra razão para essa 'abertura' remete ao fato de que o lado 'negro' sempre fica a cargo de Rahul e de Dionísia na medida em que ambos constituem representações da decadência para a atriz, em perfeita sintonia com seu atual estado: "Enfim, não interessa, restamos nós nesta coluna do edifício, uma preta velha. Um gato velho e eu. Rosa, Rosae” (HN, p. 51). Por isso, quando Dionísia fala, sua voz torna-se quase inaudível para Rosa ou Diogo, como no dia em que anunciou que haviam transcorrido três anos da morte de Gregório, lembrança ocasionada por sua ‘visitação' diária ao calendário e ouvida apenas por Rahul, que realmente o amava.

Embora considere as mulheres suas inimigas, a velha atriz estabelece uma relação de 'cumplicidade' com sua empregada 'velha' e 'pobre'- condições que afligem Rosa inclusive no que se refere à escolha dos amantes por Cordélia -, porque, aos olhos da patroa, Diú não lhe oferece nenhuma espécie de risco, como mulher, em condição social e em faixa etária. Por essa razão, ela é escolhida para exercer mais uma tarefa, além dos cuidados com a casa e com a patroa: a de confidente, que escuta os sonhos da atriz e imprime-lhes interpretação, que ouve seus lamentos durante a bebedeira e assiste à denúncia da idade avançada. A empregada, no entanto, se permite ser rabugenta com a patroa, com a qual tem uma relação calcada na atenção, mas não na devoção, como observa a própria atriz. Essa atitude pode ser observada inclusive na maneira como Dionísia se refere a Rosa nos momentos em que a atriz está completamente embriagada: "Vai, levanta". "Vai, dorme." Apesar da aparente 'cumplicidade' e até da liberdade gozada por Dionísia na relação com a atriz, sua condição de empregada permanece inalterada, como revela a maneira como se dirige à patroa que se encontra na mesma faixa etária: 'senhora'. 
Morando no mesmo local onde trabalha, seus aposentos tornam-se extensão daquele espaço, em que a mulher e a empregada confundem-se, confundindo também os limites que separam as atividades como doméstica e as de cantora no coral; embora tenha plena liberdade de ir e vir, Dionísia continua, de certo modo, presa ao ambiente doméstico. Mais interessante ainda é notar que a empregada, em contraponto com a patroa, devido à falta de profissionalização e oportunidades, reproduz justamente uma divisão sexual do trabalho doméstico, que continua a pender, mesmo quando exercida profissionalmente, para o lado da mulher.

Ao contrário de Rosa, que se esconde da realidade social a qual acredita não poder mudar, Dionísia é uma das personagens que mais circulam pelos cenários urbanos, enfrentando a cidade e seus problemas e participando de atividades que lhe permitam algum tipo de inclusão e momentos de glória, como a do canto no coral da igreja que frequenta. Diogo, apaixonado por jazz, observa que, com sua voz de contralto, a empregada poderia ser uma grande cantora mas, no papel de ouvido para Rosa, sua voz fica em segundo plano. Portanto, no romance, "Dionísia não 'significa', a não ser em relação a Rosa." 139

Vale destacar que essa mulher negra e pobre, que já integrara o enredo de Verão no Aquário (1963) e também do conto "As cerejas", volta, em As Horas Nuas, na mesma condição de empregada doméstica ${ }^{140}$, transformada também em confidente, como nos outros textos de Telles. A presença da personagem nessa posição ao longo da obra dá relevo a uma questão de classe que se delineia nos subterrâneos do texto: a permanência do negro nos bastidores, confirmando a posição de subalternidade que historicamente lhe vem sendo garantida como presença obscura desde os tempos das sinhás e da casa-grande na representação literária. A construção dessa personagem é delineada pela condição de "escrava" e "fanática", atingida em cheio pelos discursos religiosos reconfortantes da última moda, pelas previsões 'zodiacais' e pela indústria da cultura, considerações expressas nas referências aos inúmeros ensaios na igreja e ao fato de amanhecer ouvindo a programação do rádio e anoitecer entretida com a 'corcundinha da novela', os 'vasos comunicantes' a que a protagonista se refere. Nesse sentido, no olhar de Rahul, e mesmo no de Rosa, quando se referem à inserção completa da empregada no caldo de cultura para as massas, evidencia-se,

\footnotetext{
139 SCHWANTES, Cíntia. Preto no branco: as relações inter-raciais em As horas nuas e O eco distante da tormenta. In: Estudos de Literatura Brasileira Contemporânea, Brasília, n.28, jul.-dez. 2006, p. 63.

${ }^{140}$ O nome Dionísia, nos romances de Lygia, remete à figura da mulher negra, seja em Verão no Aquário, em As Horas Nuas ou em As Meninas. Com exceção deste último, no qual Dionísia é o nome da mãe da personagem Lia de Melo Schultz, os outros textos de Lygia trazem Dionísia como a empregada doméstica negra que conhece os segredos mais íntimos das protagonistas e é capaz de refleti-los em sua 'face furiosamente negra'.
} 
mais uma vez, a posição de superioridade que Rosa, como atriz teatral com grande conhecimento cultural, e seu gato, com uma visão ampla sobre a existência humana, adotam com relação a Dionísia e à atividade por ela exercida.

Ao leitor, ganham relevo outros questionamentos sobre essa personagem, os quais se coadunam aos feitos por Rahul no fragmento do romance presente no início desta análise: quais seriam suas memórias? Teriam algo de 'deslumbrante', como têm as memórias de sua patroa? Estariam ligadas à passagem do tempo e ao enfrentamento da velhice de modo mais natural? Considerando-se a poética feminista de Lygia, no sentido de que a escritora insere personagens femininas de diferentes classes e raças em As Horas Nuas para discutir a multiplicidade da categoria 'mulheres' no contexto brasileiro, esse vazio, no que toca a figura de Dionísia, sugere a quase completa inexistência da representação da mulher negra dotada de subjetividade em textos literários. Uma visão superficial do problema poderia apontar as causas daquele vazio no desconhecimento da escritora sobre a referida problemática, preocupada com a representação da experiência da mulher branca e de classe média, que também é a sua; isso, no entanto, camuflaria os recursos narrativos adotados por Lygia Fagundes Telles para denunciar justamente a falta de auto-expressão da empregada negra como personagem recorrente em nossa literatura. Ao contrário, o subalterno, aqui, tem alguma expressão a partir da representação feita não pela protagonista, foco do romance com quem Dionísia mantém uma relação especular às avessas, mas sim por outro personagem igualmente sem voz, mas repleto de subjetividade - o gato - e a partir da onisciência narrativa que apresenta ao leitor o diálogo entre a empregada e Renato Medrado no último capítulo do romance. Isso responde ao questionamento de Rahul sobre não saber o significado de uma 'mulher, preta, pobre e feia'. Sua 'verdadeira' condição será delineada quando for possível sua visibilidade em termos de voz e de vez, ao desempenhar novos papéis sociais e for alvo de diferentes representações, mas principalmente, de autorrepresentações no âmbito da literatura.

\subsubsection{A face alienada do espelho}

"Mulher detesta mulher. (...) ainda aquele clima de competição com o rei reinando entre as odaliscas. Só essa história de mãe com filha é que funciona. Às vezes” (HN, p. 18). 
Essa história funcionou entre Rosa e sua mãe, a qual considera sua única amiga, a figura típica maternal de 'olfato de vidente', que cerzia meias e fazia a 'melhor goiabada do mundo', com quem Rosa estabeleceu uma relação de cumplicidade e amor dentro de um universo absolutamente feminino, marcado inclusive pela ausência física da figura paterna. Pode-se dizer que a mãe da protagonista, inicialmente como modelo de mulher pequeno-burguesa, "formada para a esfera da família e não para o espaço social, pôde, como mãe, preservar valores ditos "pré-capitalistas", com os quais Rosa “(...) experimentava um amor incondicional, subtraído à lógica do Capital." ${ }^{141}$

O mesmo não se pode dizer sobre o relacionamento da atriz com sua filha. A menção que Rosa faz a Ananta, durante uma sessão de terapia, sobre o nascimento de Cordélia e o fato de esta ter nascido mulher, revela que na protagonista convivem traços que confirmam sua crença em uma suposta 'superioridade masculina" ${ }^{142}$ e seu desprezo pelas mulheres:

(...) Engravidei tão feliz, sonhando com um menino que ia se chamar Miguel. Comecei a chorar tanto quando me disseram que era menina, você sabe, homem sofre menos. Apanha menos. Na rua, na cama, em qualquer lugar é ele o agressor. Sem falar no parto, sabe lá o que é um parto? O mundo saindo por entre suas pernas (...).(HN, p. 138)

Esses mesmos traços, no entanto, são ironicamente desconstruídos por sua capacidade, na condição de mulher, de gerar uma nova vida, apesar do sentimento de violência que acompanha esse processo do ponto de vista de Rosa. Isso também ocorre em seu discurso ambíguo, no qual, páginas antes, a ideia de inferioridade feminina é subvertida: "Não adianta nada, o homem não tem jeito e já faz tempo, toda nossa história é um horror. Pensando bem, apesar da fenda entre as pernas a mulher ainda é melhor. Pelo menos era. Pirou nessa puta luta pelo poder, ela quer o poder." (HN, p. 136- grifo meu)

Contrariamente à atriz na mesma idade, Cordélia não apresenta nenhum tipo de vocação. Rosa questiona onde foi que errou para ter uma filha que gasta seu tempo com inúmeros banhos, compras, leitura de revistas sobre cinema e relacionamentos com homens mais velhos, com os quais "quase morria de prazer". No processo de evocação do passado, Rosa recorda-se que acreditara que a filha de trinta anos e de 'quadris adolescentes', tornarse-ia uma tenista importante, pois chegou a ganhar algumas taças, ou que seguiria a vocação

\footnotetext{
${ }^{141}$ MATOS, Olgária. Masculino e Feminino. Revista USP, São Paulo, n. 2, jun., jul. e ago. 1989. Disponível em: $<$ http://www.usp.br/revistausp/02/19-Olgária.pdf $>$ Acesso em:16 maio 2009, p.135.

${ }^{142}$ Esta idéia também é compartilhada por ALMEIDA, Sandra R.G. Castration and melancholia in Lygia Fagundes Telles' As Horas Nuas. Op.cit..
} 
do pai, com quem passava horas conversando sobre a mecânica celeste. O retrato atual de sua filha, cujo corpo é parecido com o de Rosa na juventude, contrasta, no entanto, com a imagem da foto da infância, a da meninha angelical na bicicleta, que colecionava pedras e folhas $\operatorname{secas}^{143}$.

Cordélia representa, para Rosa, a negação da velhice, assim como Ananta e Diogo são as imagens do tempo diante de si. A relação da atriz com a filha é regida, por parte da protagonista, por um misto de amor e inveja, pois Cordélia representa aos olhos da mãe a juventude que ela própria perdera. Por essa razão, Rosa não concorda que a filha procure homens mais velhos, já que, deste modo, Cordélia afastar-se-ia de sua juventude ou até se prevaleceria dela, oferecendo-a a uma "tropa de velhos." Seu desejo era ter "uma filha normal', mas a jovem saiu o "avesso do modelo da filha que vem para acrescentar e não para diminuir”. (HN, p. 34)

\begin{abstract}
Vai ver, é inveja, estou ficando velha e me ralo de inveja dos jovens que vêm cobrindo tudo feito um caudal espumejante, o ralador da inveja rala mais fundo do que o ralador de queijo. Inveja de Ananta, inveja de Cordélia também de Cordélia? é claro, inveja de minha filha. (...) a verdade é que eu queria apenas uma filha normal - será pedir muito? Podia ser livre, podia morar longe com sua tropa de amantes, aceito. Mas não precisava ser uma tropa de velhos. (HN, p. 21-22)
\end{abstract}

Cordélia assume seus desejos publicamente, relatando ter encontrado prazer por oferecer prazer aos 'velhinhos' com os quais se relacionava. Se por um lado, a partir dessa personagem, Lygia verbaliza a existência do prazer feminino, até há pouco tempo impensada para a mulher, por outro, impregna de vulgaridade essa exposição da intimidade. Na filha de Rosa, a autora discute, pelas vozes narrativas da protagonista, com seu olhar até certo ponto conservador, e de Ananta, detentora de uma visão mais liberal sobre o feminino, a emergência do que Giddens denomina sexualidade plástica, isto é, a sexualidade descentralizada, liberta das necessidades de reprodução, como traço da personalidade, vinculada ao eu, crucial para a emancipação implícita no relacionamento puro e para a reivindicação da mulher ao prazer sexual ${ }^{144}$. É interessante observar que Rosa critica a banalização da prática sexual da época na figura das jovens que imagina serem atendidas por Ananta na delegacia da mulher ou nas

\footnotetext{
${ }^{143}$ Essa descrição de Cordélia menina é bastante semelhante à de Raíza na infância, do romance Verão no Aquário. No entanto, a relação conflituosa entre mãe e filha, presente nesse romance, é revelada do ponto de vista de Raíza, a protagonista, e não de sua mãe, Patrícia, contrariamente ao que acontece em As Horas Nuas. Isso ocorre obviamente pelo fato de Raíza e Rosa Ambrósio serem personagens-narradoras nos dois romances, nos quais focalizam o próprio conflito em detrimento do ponto de vista das outras personagens.
}

${ }^{144}$ GIDDENS, Antony. A transformação da intimidade. Op.cit., p. 10. 
adolescentes envolvidas em escândalos sexuais em família relatados por Dionísia que, por sua vez, é informada dos fatos pelos noticiários de TV. Tal crítica, no entanto, não se aplica aos relacionamentos de Cordélia, uma vez que a atriz não condena textualmente sua filha, a quem se refere ora como 'pobrezinha', como 'menina', ora como traidora. Sua indisposição com relação à filha refere-se única e exclusivamente à idade e às condições financeiras de seus amantes $^{145}$, mas ela raramente manifesta tal sentimento diante da filha; na maioria das vezes, finge concordar e sofre às escondidas. A preocupação de Rosa com relação a Cordélia não se explica, portanto, pelo simples fato de que esta veio ao "mundo a passeio" e "cumpria a sua vocação" (HN, p. 78), mas sim, porque ela se relaciona com homens velhos e pobres, características que remetem à dupla condição de Rosa, que se desdobra em dois momentos significativos de sua vida: a faixa etária desses homens é a mesma em que a atriz se encontra; e fato de serem pobres está intimamente ligado à vida de privações que tivera na juventude.

Ananta observa que Cordélia adotara um cabelo de andrógino e uma tatuagem de dragão de asas entre os seios de ninfeta. $\mathrm{O}$ cabelo, historicamente associado à feminilidade, mas cortado à maneira de 'um rapazinho' por Cordélia, e a tatuagem, alvo de preconceito por estar associada a grupos socialmente marginalizados, além de serem marcas de estilo comuns da década de 80, apontam para uma desnaturalização da aparência feminina, que a androginia que reinava na moda do período ajuda a realizar. No comentário da analista revela-se, no entanto, a outra face da moeda: a crítica à efemeridade das escolhas femininas condicionadas por padrões de comportamento e estilo que tornam o corpo um portador visível de uma identidade também efêmera: “(...) uma outra espécie de vida que era alegre e transitória e vã” (HN, p. 78). Essa 'outra espécie de vida' que Ananta atribui a Cordélia é, de certo modo, a mesma vivida pela protagonista de As Horas Nuas na fase adulta. O gosto por perfumes - e sua ligação semântica com perfumaria, supérfluo - e a linguagem utilizada por Rosa e Cordélia reforçam sua semelhança de comportamento. A percepção de Rahul acerca da presença do adjetivo 'deslumbrante' nos discursos de ambas (“O que não era deslumbrante para mãe e filha?") é reveladora do quanto elas estão ocupadas com as próprias frivolidades, enquanto ocorrem desgraças das quais elas estão a salvo: povo enganado, violência extremada, trabalhador empobrecido, educação de péssima qualidade. Por tais razões, a

\footnotetext{
${ }^{145}$ Esse ponto de vista também é adotado pela escritora de As Horas Nuas, como fica evidente no trecho de uma entrevista concedida a Enio Squeff, na qual Lygia mostra-se radicalmente contra a promiscuidade sexual: "Uma situação que coloca a mulher na posição inversa da anterior, mas que a coisifica de qualquer modo - em que o tabu da virgindade dá lugar à prostituição velada". SQUEFF, Enio. Timidez e afirmação da escritora brasileira. In: O Estado de S. Paulo. São Paulo, 08 abr. 1973. Suplemento Literário, p. S. - 19.
} 
personagem Cordélia, que assim como Dionísia não se autorrepresenta no romance, pode ser caracterizada com a mesma metáfora com a qual Rosa se autodenomina: mulher-nuvem, que se desmancha e ganha novas configurações a cada sopro das novas circunstâncias.

É interessante observar que Cordélia e o primo de Rosa, Miguel, tão afastados no tempo, apresentam traços de semelhança identificados pela protagonista na recordação dos hábitos de garoto 'rico e sem dinheiro', que se enfastiava rapidamente dos objetos que comprava, que percorria revistas e logo já se desinteressava e as jogava fora, do mesmo modo que Cordélia: "Primos longe, hem?! E parecidos na sua natureza mais profunda" (HN, p. 214). No silêncio discursivo do que Rosa chama de 'natureza profunda', a leitura se dá em outra direção: apesar da distância que os separa no tempo, a filha de Rosa e o filho de tia Lucinda são herdeiros de uma burguesia que permanece rica e com valores decadentes: não precisam trabalhar, gastam o dinheiro dos pais em coisas supérfluas, levam uma vida devassa e inconsequente. Mudam-se as circunstâncias históricas - a industrialização e a modernização que se institui no país desde a década de 50 prepara o terreno para a inserção do Brasil, nos anos 80, na era da globalização e da cultura de massa; desmantela-se a moral sexual - as mulheres, como Cordélia, também podem abrir mão do casamento, da virgindade e garantir o controle da reprodução; o medo da sífilis, que assombrava os jovens no tempo em que a protagonista era Rosinha, dá lugar ao da AIDS, que tanto assusta Rosona, mas a essência é a mesma. Miguel e Cordélia, como filhos da alta burguesia, apresentam uma condição economicamente favorável que não os leva a ter grandes ambições. Por tais razões, esses 'filhos da burguesia' insurgem-se contra as aparências e os 'bons modos' que seus pais insistem em preservar diante dos familiares, dos amigos.

Quando se pergunta onde foi que errara com relação a Cordélia, a resposta para Rosa pode ser facilmente encontrada no fato de que diferentemente de sua própria mãe, a protagonista deixou de ser a "mediadora e a pacificadora entre o filho e a dura realidade, tornando-se sua porta-voz"146. O que a atriz transmite à sua filha são os mesmos valores que pautaram sua vida na condição de 'burguesa alienada' e assumida. No desempenho da maternidade, o papel de Rosa, segundo ela própria, foi o de 'mãe egoísta', extremamente preocupada com seus próprios desejos. Se não faltou amor pela filha, sobrou falta de cumplicidade.

Como Rosa na adolescência, Cordélia também experimentou a ausência da figura paterna. Diferentemente da atriz, no entanto, sua filha repete um esquema tradicional que se

${ }^{146}$ MATOS, Olgária. Masculino e feminino. Op.cit., p.135-136. 
explicita na busca dessa figura masculina em homens mais idosos - o pai por tanto tempo ausente, torturado, isolado, exilado. A opção da filha de se relacionar com velhos era motivo de discordância entre Rosa e Gregório, o qual aceitava a escolha de Cordélia, mas é curioso que a atriz jamais emite sua verdadeira opinião quando conversa com a filha - faz apenas menções. Pela técnica da alusão, no entanto, a escritora conduz o leitor à tarefa de captar no texto os sentidos irônicos sugeridos pela ausência paterna de Gregório em relação à filha e a opção de Rosa por homens mais jovens. A atriz condena veementemente em Cordélia seu desejo por homens mais velhos, sem atinar que ela mesma é a imagem de mulher mais velha procurada pelo amante, que experimentara a ausência da mãe. O complexo edipiano que se manifesta na busca de Cordélia por homens mais velhos e pobres manifesta-se, de modo semelhante, em Diogo, que alia o encontro da figura materna em Rosa com a possibilidade de ascensão econômica no papel de gigolô que desempenha. A figura do amante nesse sentido é reforçada pela passagem em que ele, bêbado, sente-se repleto de culpa e remorso depois de uma noite de amor com Rosa, projeção da própria mãe, e pede-lhe que leia os Mandamentos: "Mas já vi que a antiga fé ressurge inteira quando ele fica criança de novo. Fácil de entender, a mãezinha levava o menino para os preparatórios da Primeira Comunhão, mas com que força essa coisa da infância às vezes reaparece.” (HN, p. 13)

No universo teatral em que a protagonista está mergulhada, o nome Cordélia remete evidentemente à filha caçula de Rei Lear, da tragédia de Shakespeare. Como a personagem shakesperiana, Cordélia ama o pai na medida certa, justa; no entanto, no que se refere a Rosa, a filha desligada apresenta um comportamento quase indiferente. Na peça de Shakespeare, Lear encontra a "dignidade heróica" em sua "humanidade sofredora", e não em suas posições "como rei e como pai"147. Tal qual esta personagem, a velha atriz, consciente das transformações que aos poucos levam seu "corpo a cair em desgraça", é obrigada a despojarse da vaidade de 'estrela antiga', de diva, de deusa, para se assumir como uma mulher comum, portanto humana, e assim, admitir seus erros e acertos de acordo com as escolhas realizadas no passado, inclusive como mãe ausente. Rosa passa da posição de alazón, herói típico da tragédia, aquele que é um impostor no sentido de que se auto-ilude, para a de eíron, personagem comum na literatura irônica, que é o ser que se censura, se deprecia ou que é tratado modestamente ${ }^{148}$. Seu processo de 'decadência' não é apenas resultado do envelhecimento natural, como vimos, mas também fruto das tensões e desgastes provocados

\footnotetext{
${ }^{147}$ FRYE, Northrop. Anatomia da crítica. Op.cit., p. 233.

${ }^{148}$ Ibid., passim.
} 
pelas relações familiares e sociais, permeadas pelas idéias de sucesso e espetáculo. Em sua representação como mulher, recai o peso de não se autorrepresentar como mãe.

\subsection{A deposição das máscaras}

Em “Apenas um saxofone"149, publicado originalmente em 1970, está o cerne do enredo e de algumas personagens que, dezenove anos mais tarde, dariam vida ao romance As Horas Nuas. O conto pode ser interpretado como uma espécie de esboço para o romance posterior, até mesmo pela condensação exigida por aquele gênero, em que o fluir solitário da consciência e da memória da ex-prostituta Luisiana, a protagonista, dá o tom melancólico ao seu mea culpa, iniciado com a percepção de seu envelhecimento e às perdas e ganhos que se deram ao longo da vida, como ocorre com Rosa Ambrósio. A motivação para essa viagem ao interior de si mesma é idêntica em ambas: elas percebem que a riqueza conquistada e alimentada pela ganância não garante sua felicidade; clamam, por isso, pela volta do amado, por elas dispensado de alguma maneira; a tensão opulência x miséria, aparência x essência sustenta a construção dessas personagens que percebem, enfim, que a paz tão sonhada está longe da aquisição dos bens materiais. Por isso, o grande ponto de contato de Luisiana com Rosa encontra-se na lembrança de que tivera muitos homens, mas destes retivera apenas três: um velho grosseiro que sustentava seu alto padrão de vida; um jovem sempre em desalinho, que tocava saxofone; e o intelectual, que ela chamava de Xenofonte, o historiador grego responsável pela divulgação do pensamento de Sócrates. Até mesmo a linguagem usada pela protagonista de "Apenas um saxofone" e a disposição do espaço em que se dá seu processo de desnudamento guardam semelhanças com o universo de Rosa: a escuridão do quarto, a companhia do uísque como elemento fundamental para que mantenha a 'lucidez ${ }^{150}$ e a necessária solidão são elementos indispensáveis para esse processo. Não falta nem mesmo a referência ao frio, sentido por ambas as personagens, metáfora explícita da ausência do ser amado, cuja presença é representada como fonte de calor para Rosa e Luisiana. No entanto, é interessante notar, na descrição do saxofonista e de Xenofonte, amantes de Luisiana, alguns

\footnotetext{
149 TELLES, Lygia F. Apenas um saxofone. In: Antes do baile verde. Posfácio de Antonio Dimas. São Paulo: Companhia das Letras, 2009.

${ }^{150}$ Essa também é uma característica da jovem Ana Clara, personagem de As meninas, que busca no álcool e nas drogas alucinógenas um refúgio frente às terríveis lembranças do passado, cujas raízes encontram-se na desestruturação familiar e na consequente miséria que vivera na infância e na adolescência.
} 
elementos que, misturados, de algum modo, integram a composição de Gregório e Diogo, da perspectiva de Rosa, em As Horas Nuas.

Xenofonte, de hálito de hortelã, dava a Luisiana aulas sobre 'doutrinas filosóficas', vestido com seu 'terno de velório empoeirado e suas botas de viúvo', guarda semelhanças com Gregório, esposo de Rosa, frequentemente descrito pela protagonista como o intelectual sonhador, de 'hálito azulado espiralado' e de sapatos velhos. O homem que Luisiana reconhece ter amado e com quem gostaria de retomar a vida foi o jovem que tocava saxofone. Segundo o rapaz, de sensibilidade apurada, o saxofone era seu instrumento e, Luisiana, sua música. Conforme a ambição falava mais alto, Luisiana impunha ao amante condições baseadas justamente na validade desse amor: Se você me ama, faça isso e aquilo, começando por pequenas violações, como gritar em público, passando pela exigência de frequentar restaurantes caros e comprar à amante presentes luxuosos. Até que a ex-prostituta, sentindo medo diante da responsabilidade de tanto amor e considerando a falta de ambição do rapaz, faz o pedido derradeiro: “(...) se você me ama mesmo então saia e se mate imediatamente."151

Luisiana sente, no presente da narrativa, o desejo de ouvir novamente aquele saxofone, assim como Rosa Ambrósio sente saudades do som do mesmo instrumento vibrando nos discos de jazz ouvidos pelo jovem amante Diogo. Nos acordes do saxofone encontra-se o elo que une a figura despojada do jovem músico, do vaidoso gigolô dos sapatos italianos, mas também de Gregório: a presença de Deus, da infância e do sexo vivo e casto. Assim como a música e as histórias deveriam ser cheias de invenções para o saxofonista, pois "é triste quando um caso fica a vida inteira igual”, o poder da imaginação permite que aquelas características, misturadas e apenas sugeridas no conto, evidenciem-se, com todo o vigor, na relação que se estabelece entre os amores de Rosa Ambrósio e as personagens com quem ela contracenou nas diversas peças de teatro em que trabalhou, como veremos em seguida.

\subsubsection{O demônio do lar}

No papel de Martha, da peça Quem tem medo de Virginia Woolf? ${ }^{152}$, Rosa obteve grande sucesso como atriz e é sintomático o fato de que Diogo a tenha visto pela primeira vez

\footnotetext{
${ }^{151}$ TELLES, Lygia F. Apenas um saxofone. In: Antes do baile verde. Op.cit., p.40.

${ }^{152}$ De todas as peças mencionadas por Rosa, Who's afraid of Virginia Woolf? e Arlequin Poli par l'amour são as mais significativas em termos de mediação no tocante à construção das personagens de Gregório e Diogo e aos papéis sociais de esposa e amante decorrentes desse jogo de representação no que concerne à protagonista. Por essa razão, debruço-me em mais detalhes sobre estas duas peças citadas.
} 
justamente quando ela encenava essa peça. Diante de uma atuação tão extraordinária e convincente, o rapaz chegou a acreditar que ela daria continuidade àquele 'inferninho doméstico' em sua própria casa. Sem atinar que nesse 'disparate' havia um fundo de verdade, Diogo reforça a constatação, já feita por Rahul e Ananta, de que a atriz misturava 'seu próprio repertório' ao das peças que outrora encenara.

Guardadas as devidas proporções entre a estrutura de Quem tem medo de Virginia Woolf ${ }^{153}$, como drama marcado pelo tom intimista, e a de As Horas Nuas, como romance fragmentado, não-linear e com três vozes narrativas diferenciadas, é possível apreender que as ações que se desenvolvem na peça apresentam-se como referências dissolvidas e misturadas no romance de Telles. A sequência dos três atos do drama estabelece um forte paralelismo com os fatos ligados ao casamento de Rosa e Gregório e o período em que a atriz brilhava nos palcos; o início de seu processo de envelhecimento e a chegada de Diogo; e a expurgação das culpas e sofrimentos no presente da narrativa, que fica a cargo da dialética do lembrar/esquecer, do expor/esconder operada pela memória. Pode-se dizer que o drama familiar de Rosa Ambrósio espelha-se no de Martha, de Quem tem medo de Virginia Woolf?, mas sofre 'reflexos' de outras duas peças como Longa Jornada Noite Adentro e Macbeth.

A peça de Albee retrata a tentativa de transposição das situações de dor e confusão que fazem parte da vida das personagens e que elas rejeitam veementemente. No primeiro ato, Fun and Games (Diversão e Jogos), George e Martha, na madrugada de um domingo, recebem em sua sala de estar, após uma festa, um professor de Biologia e sua esposa, recémchegados ao campus de uma pequena universidade em New England, New Carthage, que pertence ao pai de Martha, onde George também trabalha como professor de História. As visitas são arremessadas para o turbilhão, regado a gim, conhaque e uísque, de 'jogos', questionamentos e agressões mútuas dos anfitriões; a principal diversão de Martha no primeiro ato é a de jogar o jogo de 'Humiliate the Host' (Humilhar o Anfitrião), no qual ela despreza o marido e insinua-se para o jovem Nick. A impetuosa Martha compartilha com os estranhos, além de sua profunda decepção com George, acusando-o de não ser capaz de assumir o Departamento de História e a própria faculdade devido à sua falta de ambição, algo que está escondido e que faz parte da vida desse casal que encontrou, na fuga para a fantasia um filho imaginário -, um modo de sustentar a solidão a dois, oriunda de seu difícil relacionamento. No segundo ato, Walpurgisnacht ${ }^{154}$, o processo de revelação das insatisfações

\footnotetext{
${ }^{153}$ ALBEE, Edward. Who's afraid of Virginia Woolf? New York: Signet, 2006.

${ }^{154}$ Walpurgisnacht ou Noite de Walpurgis é um tradicional feriado religioso de origem pré-cristã, celebrado tanto por comunidades cristãs quanto por não-cristãs, na noite de 30 de abril e madrugada de $1^{\circ}$. de maio em
} 
e desilusões do casal desencadeia o enfrentamento da verdade por meio de mais 'jogos' que, a partir de então, atingem diretamente Nick e Honey com suas agressões verbais e provocações. Oscilando entre uma calma fatigada e um ódio contido, George consegue fazer Nick trazer à tona seus segredos mais recônditos; o anfitrião, humilhado no primeiro ato, decide jogar, então, 'Get the Guests' ('Pegar' os convidados) e, com as informações obtidas, executa um verdadeiro massacre no relacionamento do casal. George revela a Honey, por meio de uma pequena história protagonizada por Mousie, representação da esposa de Nick, que a razão de seu casamento não se deveu apenas a sua gravidez 'histérica', mas teve uma motivação financeira, devido à herança que possuía. Martha e George continuam trocando acusações e, depois do incidente com Nick e Honey, declaram "Total War” (Guerra total), cada qual visando à destruição moral do companheiro. A atmosfera claustrofóbica da peça continua sendo tecida pelos diálogos que expressam as complexidades da existência não idealizada das personagens, especialmente encerradas na sala de estar dos anfitriões. O ambiente vai tomando as configurações do mundo do pesadelo e do cativeiro, do qual nenhuma personagem pode escapar até a total expurgação das culpas de cada uma delas. A essa altura, as personagens já estão completamente embriagadas e Honey, frágil e 'sem quadril', permanece deitada no ladrilho do banheiro da casa de Martha, tentando superar mais um de seus intermináveis enjoos, enquanto Nick, segundo George, brinca de jogar 'Hump the Hostess' ('Transar' com a Anfitriã), mais uma das provocações de Martha; esta é a última humilhação a que o anfitrião se submete pois, embora finja não se importar com o relacionamento sexual de sua esposa com o jovem biólogo, o que não ocorre efetivamente, este é o último golpe e sua vingança será à altura.

alguns países da Europa, como Alemanha, Inglaterra, Finlândia e Estônia. As cerimônias realizadas nesta noite têm suas origens em tradições pagãs vikings que celebravam a chegada da Primavera. Nessa ocasião, milhares de fogueiras são acesas as quais, originalmente, eram construídas para afastar a morte e os maus espíritos que, segundo a crença, andavam entre os vivos, pois, nessa noite, também considerada a do Sabbah satânico, as bruxas promoviam orgias. O ritual era seguido pelo retorno da luz e do sol simbolizando a chegada da primavera, embora o simbolismo das fogueiras e das bruxas esteja mais intimamente associado com a Páscoa. Em muitos países, o festival passou a ser chamado de Santa Walburga devido à 'coincidência' da celebração das festividades em honra desta santa na mesma data do feriado pagão no qual era baseado - uma provável estratégia de cristianização de rituais pagãos, que transformou o festival numa mistura dessas celebrações, criando, portanto, a Noite de Walpurgis. Na peça de Edward Albee em questão, a referência a essa noite como título do segundo ato está ligada às revelações mais cáusticas das personagens, quando 'as bruxas estão soltas', os piores sentimentos e provocações vêm à tona; há a clara percepção de que uma transformação necessária e iminente está por vir. Por essa razão, este ato é uma espécie de preparação para o efetivo 'exorcismo' em que se constituirá o terceiro e último, que recebe, inclusive, esta última denominação. Como demonstro ao longo desta tese, a ideia de ressurreição, de fazer algo novo e renovado tomar o lugar do velho e 'apodrecido' permeia o romance As Horas Nuas do início ao fim, tanto no plano individual da protagonista, com o sentimento nostálgico do passado e a busca da juventude em um amante mais jovem, quanto também do desejo de que uma nova ordem social garanta seu lugar, uma vez que a protagonista está cansada dos discursos políticos, das mazelas sociais, desastres naturais e provocados pelo homem, para cujo fim sente não poder dar uma contribuição efetiva. 
No último ato, The Exorcism (O Exorcismo), devidamente preparado pelas cenas do ato anterior, George resolve jogar o último jogo, 'Bringing Up Baby' (Criar o Bebê), em que ele, à revelia da esposa, "mata o filho" imaginário, destruindo com isso, a ilusão que sustentava sua relação com Martha e obrigando a si e a esposa a viverem, daquele momento em diante, encarando sua terrível realidade, como sugere a ficção de Virginia Woolf- daí o nome da peça. Ao final, quando o casal Nick e Honey tem permissão para deixar a casa, George canta suavemente 'Who's afraid of Virginia Woolf?' (Quem tem medo de Virginia Woolf?), questão respondida positivamente por Martha: "Eu tenho, George. Eu tenho", revelando o problema central da obra: o medo do enfrentamento da vida sem ilusões.

As imagens que representam a realidade daquelas personagens dão indícios do mundo do não desejável e podem ser consideradas em conjunto pelo que Frye denomina analogia da experiência ${ }^{155}$, cujas ideias estruturais são a gênese e o trabalho, imagens comuns da experiência. $\mathrm{O}$ uso da bebida alcoólica pelas personagens, tanto na peça quanto no romance, é um elemento importante na medida em propicia uma espécie de relaxamento, eliminando a censura ao que pode ou deve ser dito. O drama de Albee apresenta características do mythos do Inverno, em que prevalecem a ironia e a sátira que podem caminhar para o mais cruel realismo, com as imagens da dor, da confusão e do sofrimento. Isso explica por que Rosa Ambrósio temia que, por sua culpa, se "repetisse lá fora o clima podre da peça", justamente num momento "quase perfeito" do relacionamento com Gregório, quando atuava em Quem tem medo de Virginia Woolf?. No entanto, a inserção de uma personagem jovem, atraente e ambiciosa como Diogo na vida da atriz desencadeia a revelação da decadência de seu casamento, como ocorre com Martha e George com a chegada de Nick. O marido de Martha e Gregório constituem representações do envelhecimento, da falta de ambição em âmbito pessoal e do prazer pela atividade intelectual. Por sua vez, o esposo de Rosa apresenta um traço característico de uma geração que se consolida durante as décadas de 60 e 70: a crença de que a transformação pessoal ocorria em função da ação política; como intelectual de esquerda, contestou na linha de frente os atos da ditadura instaurada em 1964 e, por isso, foi mais uma de suas vítimas.

As características opostas podem ser atribuídas a Diogo, pretenso leitor de Trotsky, assim como a seu correlativo em que Quem tem medo de Virginia Woolf?, Nick, professor de biologia. Embora apresentem ligações com a atividade intelectual e, no caso do primeiro, uma falsa postura de esquerda, estas duas últimas personagens utilizam-nas como meio de se

\footnotetext{
${ }^{155}$ FRYE, Northrop. Anatomia da crítica. Op.cit., p. 155.
} 
aproximar de mulheres economicamente abastadas a fim de alcançarem êxito nas conquistas, seja de altos postos no campo profissional como Nick, ou de bens materiais, no caso de Diogo. Como lembra Rahul, o amante da atriz age "como se nunca tivesse feito outra coisa do que cuidar de mulheres desbitoladas" (HN, p. 102), pois ele sabe, como Rosa atesta, que “encomendação do corpo e conquista de mulher madura tem de ser devagar (...)" (HN, p. 13), elementos indispensáveis para o sucesso de um gigolô. Por tais razões, é interessante a observação de Cíntia Schwantes, para quem "Diogo seria um típico latin lover (sic). Até suas ideias de esquerda, pelo contraste com Gregório, que realmente as viveu e pagou um preço por isso, parecem mais charme do qualquer outra coisa."156

As 'fumaças intelectuais' de Diogo, com as quais ele 'emprenhava a atriz pelos ouvidos, depois do sexo', como ela recorda, ficam apenas no nível do discurso, contrapostas à solidez dos ideais de Gregório. Essa comparação revela, acima de tudo, duas gerações separadas por posições divergentes, convivendo na mesma época: uma, intelectual, formada antes da implantação da ditadura de 64, e outra, gestada durante o regime. De modo geral, em Gregório é possível reconhecer uma formação humanista, com preocupações voltadas para o bem-estar de toda uma coletividade, inexistente na figura do amante da atriz, com interesses unicamente voltados para a satisfação dos desejos que saciem seu individualismo exacerbado. Com o golpe de 64,

O autoritarismo plutocrático fechou o espaço público, abastardou a educação e fincou o predomínio esmagador da cultura de massas. Sua obra destrutiva não se resumiu, pois, à deformação da sociedade brasileira pela extrema desigualdade. Legou-nos, também, uma herança de miséria moral, de pobreza espiritual e de despolitização da vida social. ${ }^{157}$

No jogo de espelhamento que integra o romance, pode-se dizer que Diogo, comparado a Gregório, encerra, em sua caracterização, o esgotamento do projeto de interesse pela coletividade, expresso no consumo exacerbado de objetos e na disseminação de ideais que possam integrá-lo à sociabilidade moderna. No discurso, o amante fala na busca de 'nossa identidade cultural', nos milhões de miseráveis que habitam a metrópole frente à riqueza da protagonista, no 'padre-herói', na necessária exaltação da 'face do Cristo revolucionário e da 'indignação', mas apoia suas ações nos valores capitalistas, o que se coaduna com a afirmação

\footnotetext{
${ }^{156}$ SCHWANTES, Cíntia. Preto no branco: as relações inter-raciais em As horas nuas e O eco distante da tormenta. In: Estudos de Literatura Brasileira Contemporânea. Op.cit., p. 65.

${ }^{157}$ NOVAIS, Fernando A.; MELLO, João M. Cardoso de. Capitalismo tardio e sociabilidade moderna. In: SCHWARCZ, Lilia M. (org.) História da Vida Privada no Brasil: contrastes da intimidade contemporânea. V.4. Op.cit., p.636-637.
} 
de Rahul de que o gigolô, numa provável existência anterior, fora raposa: o animal símbolo da astúcia e da concorrência desleal das fábulas moralizantes. Na prática, seu discurso revela-se oco, pois, segundo a própria Rosa, Diogo não passa de um 'boa vida', como demonstra o uso que faz de estratégias arraigadas à nossa 'identidade', acionando os resquícios de um mecanismo que, para dizer com Roberto Schwarz, "afetou no conjunto nossa existência nacional", como o do favor, nossa "mediação quase universal"158. Isso fica claro na rememoração do papel de gângster de Diogo, feita por Rahul, no episódio em que ele se apropria de um faqueiro de prata de Rosa e leva-o como presente de casamento, com o objetivo de 'amansar um delegado' que havia prendido um amigo envolvido em algum negócio escuso.

Além das diferenças de caráter que distinguem Gregório e Diogo, essas duas figuras masculinas caracterizam-se, para Rosa, nas funções que cada qual desempenha em relação a ela própria. A Diogo, como revela o gato, estavam destinados “ (...) os temas e encargos de ordem terrena", isto é, a "administração dos bens" de Rosa, a "programação de sua carreira de atriz indisciplinada", bem como a partilha da "alegria de viver" (HN, p. 34-35). Ao esposo, a atriz recorria em suas “(...) crises místicas, quando se sentia abandonada por Deus e traída pelo próprio ofício (...). Era ainda Gregório que ouvia as queixas maiores pela traição de Cordélia (...)" (HN, p. 34). No entanto, durante tais crises, o esposo era tido, na visão do gato, como "a rocha onde ela ia se estirar exausta" (HN, p. 34), com quem a atriz compartilhava os problemas de ordem espiritual/psicológica oriundos de seu afastamento da vida profissional e da chegada da velhice.

As referências feitas a Gregório pelas três vozes narrativas do romance, mas também por Dionísia e até por Diogo, confirmam-no como uma "criatura humaníssima e idealista, que o mundo triturara e levara ao suicídio" ${ }^{159}$. Etimologicamente, ao seu nome ligam-se os atributos de cuidadoso, vigilante, aquele que conquista o respeito de todos por suas atitudes calcadas na prudência, pois evita ao máximo os conflitos e não emite uma opinião sem antes refletir sobre o assunto, características também atribuídas a George. Não é gratuita, portanto, a vocação por ele escolhida, o 'sentir-se chamado' ao estudo da mecânica celeste: símbolos do comportamento perfeito e regular, representado pelo movimento circular, os astros celestes

\footnotetext{
${ }^{158}$ Para Roberto Schwarz, o favor é o nexo efetivo da vida ideológica brasileira do século XIX, que se apresenta como chave para a compreensão do deslocamento praticado das ideias europeias, postas e repostas em sentido impróprio no Brasil. SCHWARZ, Roberto. As ideias fora de lugar. In: Cultura e política. São Paulo: Paz e Terra, 2001, p.63-64. (Col. Leitura)

159 COELHO, Nelly N. As Horas Nuas: a falência da razão ordenadora. In: A literatura feminina no Brasil contemporâneo. São Paulo: Siciliano, 1993, p. 240.
} 
"participam das qualidades de transcendência e de luz que caracterizam o céu"160, que, por sua vez, simboliza a ordem sagrada do universo, os poderes superiores ao homem. Considerado também a morada das Divindades e tido como o próprio Poder divino, o céu simboliza a plenitude e a busca das aspirações humanas, como o local possível de uma perfeição do espírito $^{161}$. Por isso Gregório, que era ateu, parecia impregnado da presença de Deus, até mesmo ao se referir aos problemas da vida cotidiana com a expressão 'teoremas', termo mais leve para nomear os conflitos, pois tem 'Deus na raiz' - Teo. O físico contemplava no firmamento a transcendência divina, expressa na inacessibilidade, na infinitude, na eternidade e na força criadora do céu, mas é nas estrelas, símbolos do espírito e do conflito entre as forças espirituais e materiais, que Lygia, como escritora, oferece a representação que congrega o sofrimento de Gregório, que voltou da prisão 'irreconhecível', ao fato de ter se tornado "um homem atado por dentro num nó-cego" (HN, p. 142), que mantinha seu mundo fechado à chave

Frente à determinação de seus ideais, a posição intelectual do físico, na maneira como soluciona seus 'teoremas', tem como fundamento a liberdade, já que o homem, como ser-nomundo, está condenado à liberdade de decidir os rumos de sua vida diante da sociedade e de suas regras. Por essa razão, essa noção de liberdade, que se aproxima da concepção de Sartre, está intimamente ligada ao engajamento político e à responsabilidade, na medida em que suas escolhas são feitas para si, mas interferem na vida de outros homens, o que dota a liberdade de um caráter universal. No entanto, Gregório aceita, a seu modo, as histórias e mentiras da esposa e por isso apresenta, aparentemente, uma postura diferenciada no que tange à militância política. Tal paradoxo explica-se por sua crença naquela liberdade que deveria reger a vida de todos, em seus mais diversos aspectos: "que cada qual cuide da rosa do seu jardim, ele recomendou a um estudante" (HN, p. 37). Gregório compreende as traições de Rosa e os amantes de Cordélia porque as ama e respeita seus direitos de escolha, o que distancia seu posicionamento da mera falta de 'atividade'; por isso, esse mesmo desejo de liberdade permite-lhe escolher também o momento de 'sair de cena', quando a morte tornouse mais conveniente para o corpo em decadência.

Ao longo de todo o romance, a posição de Rosa, ao falar do esposo, oscila entre o ódio diante de seu 'sorriso para dentro', de sua postura como um "sábio do Sião ouvindo a Joaninha, a besourinha com bolinhas vermelhas na blusa" (HN, p. 51), e sua profunda

\footnotetext{
${ }^{160}$ CHEVALIER, Jean; GHEERBRANT, Alain. Dicionário de símbolos. Op.cit., p.95.

${ }^{161}$ Ibid., p. 227-228.
} 
admiração e inveja, pois ele era respeitado por todos os que, de algum modo, faziam parte de seu círculo familiar e social, até mesmo por Diogo. Esse movimento pendular, no que se refere aos sentimentos da protagonista por Gregório, é acionado pela culpa que ela sente pelo desprezo ao esposo e revela-se ao longo de todo o romance tanto em seu monólogo interior quanto nas sessões com Ananta, em que a atriz entregava-se à narração dos fatos que insistentemente a perseguiam na memória. Tal processo é semelhante ao de Martha quanto à ambiguidade de sentimentos devotados a George ${ }^{162}$ : embora o ame, deixa-o sofrer, desejando enganadoramente com isso mudar o status quo.

Com relação às traições que fizera a Gregório, ora tido como um santo, ora como pecador, Rosa sente uma culpa que nem "os mais raros perfumes do Oriente", nem toda água ou sabão do mundo seriam capazes de purificar. A partir da leitura de um fragmento da tragédia de Macbeth $^{163}$, de Shakespeare, a atriz olha para as próprias mãos, recorta e aplica à sua própria condição a famosa frase de Lady Macbeth, de que nem todos os perfumes da Arábia poderiam fazer o cheiro do sangue do rei assassinado desaparecer de suas mãos: a impossibilidade de se perdoar. O crime cometido por Macbeth e incitado por sua esposa, então, desagrega o casal, assim como a estreita e inicial união dos dois ${ }^{164}$, do mesmo modo como a 'traição' amorosa realizada por Gregório e por Rosa também os desagrega. Todas as insatisfações não reveladas apontam seus pontos fracos, fazendo apodrecer o amor, expresso

162 "Martha (to Nick): (...) There is only one man in my life who has ever ... made me happy. Do you know that? One!

Nick: The ... the what-do-you-call-it? ... uh... the lawn mower, or something?

Martha:(...) I meant George, of course. (...) Uh...George; my husband.

(...)

Martha: ... George who is out somewhere there in the dark... George who is good to me, and whom I revile; who understands me, and whom I push off; who can make me laugh, and I choke it back in my throat; who can hold me, at night, so that it's warm, and whom I will bite so there's blood; who keeps learning the games we play as quickly as I can change the rules; who can make me happy and I do not wish to be happy, and yes, I do wish to be happy. George and Martha: sad, sad, sad." In: ALBEE, Edward. Who's afraid of Virginia Woolf? Op.cit., p. 200-202.

${ }^{163}$ Nessa peça, Lady Macbeth incita o marido, Macbeth, a matar o rei Duncan para ascender ao trono escocês e, assim, antecipar a segunda profecia das bruxas encontradas na volta da batalha contra o rei da Noruega de que, além de se tornar Barão de Cawdor, Macbeth seria rei. Ele mata o rei, mas não consegue voltar à cena do crime para devolver os punhais ensanguentados; sua esposa encarrega-se de fazer o serviço, acreditando que as manchas de sangue que ficaram em suas mãos poderiam ser apagadas com um pouco d'água- seu mais terrível engano. A sede de poder leva o novo ocupante do trono escocês a matar todos os que representam uma ameaça ao seu reinado, começando pelo próprio rei e pelo companheiro de batalhas, Banquo, que segundo as bruxas, seria o pai dos futuros reis, até ficar sozinho, lutando contra o herdeiro legítimo do trono, Malcolm, que recebeu apoio dos ingleses. Lady Macbeth passa a viver em um estado de isolamento e insanidade e sua loucura originase na alucinação de não conseguir remover a mancha do sangue de Duncan que sujara suas mãos, tornando-as rubras como as de seu marido assassino, algo de que se orgulhara anteriormente. Incapaz de 'lavar' essa culpa, suicida-se, ao passo que Macbeth é morto em combate pelo filho de Banquo.

${ }^{164}$ HELIODORA, Barbara. O fim. Falando de Shakespeare. São Paulo: Perspectiva, 2001, p.139-140 
nas relações de aparência, como Rosa em seu monólogo caótico admite. O lixo acumulado, expresso nas máscaras sobrepostas de família nuclear e feliz, derrama-se sobre seus membros, que já desconhecem os motivos que levaram à situação de incomunicabilidade e solidão, responsável pela manutenção daqueles jogos, primordial para a sustentação dos papéis de esposa e esposo 'traídos e distraídos'. Gregório, amante da lua e das estrelas, em seu silêncio - a virtude dos deuses, para Rosa-, instala-se metaforicamente na solidão cósmica, ao final de sua existência, quando vai dormir em um quarto separado e é lançado para dentro dos jogos de Rosa, repletos de mentira e encenação: o de 'Humilhar o Dono da Casa', de andar trôpego, mãos trêmulas e dicção afetada pelo Mal de Parkinson, e o de 'Transar com a Anfitriã', jogado quando o amante, bem mais jovem que Gregório e a atriz, sob a máscara de secretário, entra definitivamente na vida do casal.

O desdobramento daquele 'clima podre' de Quem tem medo de Virginia Woolf?, temido por Rosa, ocorre inevitavelmente. As acusações de fraqueza, de falta de coragem, de incapacidade que Martha usa contra George, e de mimada, grosseira, vulgar, do marido contra a esposa, são semelhantes ao ponto de vista de Rosa sobre Gregório e do esposo sobre a protagonista, respectivamente. A visão deste último, no entanto, é filtrada pelas vozes narrativas da própria Rosa, de Rahul e de Ananta e permite interpretar seu posicionamento como alguém que aceita o jogo de aparências e ilusões a que foi submetido, revelando suas opiniões apenas através do olhar ou frases curtas como eram curtas as baforadas de seu cachimbo. Embora preferisse não interferir nas escolhas de Rosa, vez ou outra Gregório estendia sua mão à atrapalhada atriz, como na madrugada em que sugeriu a ceia, degustada com o "apetite da inocência", sem mentiras - os rostos nus, sem máscaras, quando Rosa chega ao apartamento após a falsa participação no ensaio de uma peça de O’Neill, "um pastelão onde não acontece nada além dos infindáveis diálogos de uma família na fossa” (HN, p. 159) ${ }^{165}$. Na lembrança dessa "longa jornada noite adentro" na companhia de Gregório, o

\footnotetext{
${ }^{165}$ Ver O’NEILL, E. Longa jornada noite adentro: drama em 4 atos. Tradução Helena Pessoa. São Paulo: Peixoto Neto, 2004. (Os grandes dramaturgos). A peça aborda questões autobiográficas referentes aos membros da família O’Neill, retratados nas personagens dos Tyrone: o casal James e Mary, e os filhos Jamie e Edmund. Permeados por breves ações corriqueiras, os diálogos intensos entre os membros dessa família transcorrem em dia do ano de 1912 e trazem à tona revelações e acusações de sofrimentos, culpas e perdas que uns atribuem aos outros, processo que se estende ao longo da noite. James, ator talentoso que, em nome da sobrevivência da família, deixa de alçar vôos mais altos na carreira profissional, para repetir o mesmo papel em suas inúmeras turnês que lhe garantia sucesso de bilheteria; Mary torna-se dependente de morfina desde o nascimento de seu filho caçula, Edmund, maneira por ela encontrada como forma de escapar à dor da perda do segundo filho, Eugene, da qual se sente responsável por estar ausente quando o fato ocorrera, e dos sonhos de menina não realizados frente às atribulações financeiras e às viagens constantes impostas pelo casamento com James. Jamie, o filho mais velho, entrega-se à vida boêmia e ao alcoolismo, como modo de fugir da culpa que sente por ter provocado a morte do irmão, quando, ainda criança, entra no quarto do bebê e transmite-lhe sarampo, além de ser acusado de levar Edmund, por inveja, a entregar-se aos mesmos vícios aos quais ele próprio se entregou.
} 
paralelismo com a peça do dramaturgo estadunidense sugere uma revisão da história do casal, também na 'fossa', condensada nos gestos adotados por ambos na última tentativa do esposo de dar novos rumos ao relacionamento. A atmosfera criada por Lygia nessa cena vai gradativamente tornando-se carregada pelo contraste entre o mundo interior de Rosa e Gregório e os elementos exteriores referentes à ceia, durante a qual ambas as personagens obrigam-se ao silêncio enquanto ingerem os alimentos, silêncio este que gera um desconforto frente à impossibilidade de fuga de si mesma, no caso da protagonista. No lugar de palavras capazes de nomear a dor e trazer à tona as mágoas arraigadas, como nas personagens do drama de O’Neill, em As Horas Nuas, Gregório olha fundo nos olhos de Rosa, que responde baixando a cabeça, confusa, recursos utilizados pela escritora para marcar a dificuldade de comunicação entre o casal na medida em que os instala na mais pura solidão. Essa atitude revela a esperança secreta do físico dos 'teoremas' de recomeçar uma nova vida com a atriz, que acaba não correspondendo às suas esperanças, como na única vez em que tentou partilhar seu mundo com a esposa, chamando-a para contemplar o céu carregado de estrelas, mas Rosa, alegando estar atrasada para uma festa, deixa o esposo na companhia da 'solidão cósmica'. Suênio C. de Lucena observa que as protagonistas femininas de Telles que relembram com nostalgia um passado glorioso,
quando casadas vivem infelizes em relações estagnadas e sufocantes, mas que não se movimentam para alterá-las, daí a aludida insistência em manter certas convenções alicerçadas em tradições burguesas. Ao contrário de provocar mudanças elas resistem até mesmo quando vivem em meio a situações de quebra de costumes. ${ }^{166}$

A essa incapacidade de transformação do relacionamento por medo, covardia e incompreensão que abrange de alguma forma o cônjuge também pode-se atribuir o fato de que

uma ética matriarcal de cordialidade, aceitação e amor que dominava a relação da família se esfacelou sob o impacto da universalização do trabalho produtivo e alienado, de tal forma que homens e mulheres estão se

Edmund, convalescente de tuberculose, com dotes literários, sente-se o verdadeiro culpado pela dependência química de Mary, e entrega-se à bebida. Na revisitação que os Tyrone fazem ao passado, revela-se a dificuldade dos membros dessa família de comunicar suas angústias, na condição de atores e testemunhas que são dos próprios erros e dos que foram cometidos pelos outros.

${ }^{166}$ LUCENA, Suênio C. Esquecimento e lembrança em Lygia Fagundes Telles. Op.cit., p.130. 
convertendo em 'meros agentes da lei do valor' e à condição de 'absoluta solidão de um objeto sem defesa. ${ }^{167}$

$\mathrm{Na}$ protagonista, sobrevive um modelo de família nuclear calcado nessa 'ética matriarcal', que ela tentou conciliar com sua realização profissional e com a exacerbação de seu caráter narcisista. Devido ao seu alto poder aquisitivo e ao exercício efetivo de sua profissão de atriz, Rosa não enfrentou, como sua mãe e outras mulheres de sua própria geração, o isolamento da vida social devido aos cuidados com a filha e com o esposo, e muito menos sofreu as agruras relativas à tradicional divisão doméstica do trabalho, o qual sempre esteve a cargo da empregada e do motorista particular. A antiga relação de poder desigual no âmbito familiar, que tendia a beneficiar os membros masculinos, encontra-se alterada no núcleo de Rosa e Gregório, no qual a protagonista tem um papel decisório muito mais atuante que o esposo.

Esse modelo de família, surgido com a consolidação da burguesia como classe na Europa do século XIX, trazia no bojo uma nova mentalidade reorganizadora das vivências familiares e domésticas, até mesmo da sensibilidade, expressa nas novas formas de pensar o amor. Gradativamente, um outro modelo que imperava no Brasil, característico da sociedade patriarcal - rural, escravista e monogâmica - sofreu progressiva desagregação com a industrialização e a ruína dos grandes latifúndios. É interessante, neste caso, a observação de Anthony Giddens sobre a natureza do amor, particularmente no que diz respeito à ascensão dos ideais do amor romântico. Nas ligações em que prevalece esse ideal, o amor sublime tende a predominar sobre o ardor sexual; o amor romântico "rompe com a sexualidade, embora a abarque; a 'virtude' começa a assumir um novo sentido para ambos os sexos, não mais significando apenas inocência, mas qualidades de caráter que distinguem a outra pessoa como 'especial"'168. No que se refere ao surgimento da ideia de amor romântico, cabe compreender sua relação com várias influências que afetaram as mulheres a partir do final do século XVIII. Uma delas foi a criação do lar. Uma segunda foi a modificação nas relações entre pais e filhos; e a terceira, o que se convencionou chamar de 'a invenção da maternidade'. No que dizia respeito à situação das mulheres, todas essas influências estavam intimamente integradas. ${ }^{169}$

\footnotetext{
${ }^{167}$ MATOS, Olgária. Apresentação à edição brasileira. In: CANEVACCI, Massimo (org.). Dialética da família. São Paulo: Brasiliense, 1982, p.10. A pensadora, aqui, baseia sua argumentação em Sociologia da família, de Adorno e Horkeimer, presente no volume citado.

${ }^{168}$ GIDDENS, Anthony. A transformação da intimidade. Op.cit., p. 51.

${ }^{169}$ Ibid., p. 53.
} 
A família burguesa integrou novos padrões de sociabilidade, em estreita relação com aquele conjunto de valores específico ligado ao ideal do amor romântico, a saber, o amor entre os cônjuges, a maternidade, o cultivo da mãe como ser especial e do pai como responsável pelo bem-estar e educação dos filhos, o amor pelas crianças e sua compreensão como seres em formação e necessitados, nas suas dificuldades de crescimento, de amor e de compreensão dos pais. Característico desse contexto, houve um distanciamento cada vez maior da família em relação à sociedade circundante, circunscrevendo-a a uma área doméstica privada em oposição à área pública. Nessa situação, embora já fosse possível a escolha amorosa do cônjuge, nessa escolha, no entanto, prevaleciam questões de classe. Nas relações da família burguesa, marcada pela valorização da intimidade e da maternidade, nasce uma nova mulher, responsável pelos filhos e pelo marido, o que levou à associação das ideias sobre o amor romântico às de subordinação da mulher ao lar e seu relativo isolamento do mundo exterior. ${ }^{170}$

A erosão daquela forma tradicional de família, um dos modelos efetivamente vigentes no Brasil até meados do século XX, é fruto de transformações básicas como as que se operaram na vida de homens e mulheres em épocas recentes, como o afrouxamento do poder exercido pelo homem sobre a mulher e os filhos, com a garantia de escolarização para a mulher e sua participação ativa no mercado de trabalho, além das conquistas concernentes ao domínio de seu próprio corpo e sexualidade. Rosa não sacrifica nem negligencia suas próprias necessidades para suprir as dos outros membros desse grupo e, desse modo, subverte uma característica que tem sido associada à das mulheres em geral: o esquecimento de si e a dedicação aos cuidados com o outro. Tal subversão se deu porque

\begin{abstract}
A nova cultura, centrada no prazer e no sexo, no lazer e na livre escolha individual, desvalorizou um modelo de vida feminina mais voltada para a família do que para si mesma, legitimou os desejos de viver mais para si e por si. O reconhecimento social do trabalho feminino traduz o reconhecimento do direito a uma 'vida sua', à independência econômica, na linha direta de uma cultura que celebra cotidianamente a liberdade e o maior bem-estar individual. ${ }^{171}$
\end{abstract}

A infelicidade conjugal e materna de Rosa provém justamente da angústia de não ter conseguido um equilíbrio entre as atividades desenvolvidas na esfera pública e os novos

${ }^{170}$ Cf. D'INCAO, Maria Ângela. Mulher e família burguesa. In: DEL PRIORE, Mary (org.). História das mulheres no Brasil. São Paulo: Edunesp/Contexto, 1997; D'INCAO, Maria Ângela. O Amor Romântico e A Família Burguesa. In: D’INCAO, Maria Ângela (org.). Amor e família no Brasil. São Paulo: Contexto, 1989.

${ }^{171}$ LIPOVETSKY, Gilles. A terceira mulher. Op.cit., p. 228-229. 
papéis de esposa e mãe, sinal de que os ideais de amor romântico que influenciam a personalidade de Rosa fragmentaram-se sob a pressão da emancipação e da autonomia. Nesse sentido, o beijo trocado por Gregório com a prima da atriz, "um impulso sem maior significação (...), a satisfação de um desejo momentâneo"172, serve apenas como pretexto explicativo para a série de 'degradações' às quais a protagonista entregou-se; como vingança à atitude do esposo, a quem não amava profundamente, a atriz utiliza-se do mesmo artifício por ele usado, o que pode ser interpretado como uma forma de puni-lo por um comportamento que reproduz a velha máxima da 'necessidade' de aventuras extraconjugais para o homem. Ao silenciar esse fato, no entanto, a protagonista age como uma mulher tradicional: não destrói o casamento em função dessa aventura, mas cala-se. A igualdade de 'direitos' nesse casamento é requerida, portanto, de maneira velada, embora ambos saibam das respectivas traições e, por isso, a relação pauta-se pela total invisibilidade e solidão. É inevitável, portanto, que o casamento seja sub-repticiamente minado e corroído por dentro, revelando que “(...) os velhos esposos que 'partilharam' a mesma existência possuem, cada qual, uma autobiografia em potencial (eles não a escrevem) que não é 'partilhada' pelo outro. E o segredo da mecânica do desejo, e de suas avarias, permanece intacto." ${ }^{173}$

Ao contrário do comportamento com seu gigolô, a atriz e o esposo nunca 'discutiram a relação' abertamente, na qual imperava a calma fatigada de Gregório, característica de George antes de ser lançado aos jogos de Martha:

-Acho que nunca discuti com Gregório. Posso urrar, me descabelar, rasgar as vestes como nas tragédias e ele vem, me levanta, passa mercurocromo nos arranhões, enxuga minhas lágrimas. Mas não se exalta. Conversa comigo tão baixo que acabo falando como ele, nós dois murmurantes. (HN, p. 112)

Entretanto, quando Diogo passa de secretário a amante, Rosa reproduz, desta vez com o jovem, a relação conflituosa do casal de meia-idade do drama de Albee, baseada em provocações mútuas, permeadas por agressões verbais, consumo de álcool, gritos e até mesmo tapas nas brigas mais acirradas. Nessa etapa, Diogo, que mantinha estreita associação com a personagem Nick, assume outros desdobramentos da representação de George, com sua irônica sagacidade. Por essa razão, a semelhança de comportamento entre o casal de Quem

\footnotetext{
172 SILVA, Vera M. T. As Horas Nuas, um jogo de deciframento. In: A ficção intertextual de Lygia Fagundes Telles. Op.cit., p.47.

${ }^{173}$ VINCENT, Gérard. Segredos de Família. In: PROST, Antoine; VINCENT, Gérard (orgs.). História da vida privada 5 - da Primeira Guerra a nossos dias. Tradução Denise Bottmann; Posfácio Dorothée de Bruchard. São Paulo: Companhia das Letras, 2009, p. 269. (Companhia de Bolso)
} 
tem medo de Virginia Woolf? e Rosa e Diogo é notória, como revela a cena abaixo que poderia ter sido encenada pelos protagonistas da peça de Albee:

Começavam mais ou menos assim as discussões entre os dois. E que podiam evoluir rapidamente para os palavrões entremeados de empurrões. Tapas. Ou ter o desfecho na cama. Os tapas vinham de Rosona, ele apenas se defendia agarrando-a pelos pulsos até vê-la sucumbida, desfeita em lágrimas. Por que não bateu em mim? Você devia bater em mim!, ela choramingou numa das brigas mais violentas. Ele preparou-lhe um uísque com uma calma fatigada. Não queira fazer de mim o chicote para suas culpas. (HN, p. 29-30)

No sentido aqui exposto, o amante da atriz, portanto, funciona como um dos elementos catalisadores das transformações ocorridas em Rosa, apontando, como Nick, para o cerne do conflito: todas 'as verdades são relativas', razão pela qual convivem, no mesmo romance, os pontos de vista até certo ponto discrepantes de Rosa e Rahul sobre a figura de Gregório. A necessidade de alimentar um resquício de vínculo com os papéis tradicionais de homem e de mulher é requerida por Rosa em seu posicionamento quanto ao dever da agressão física, ação também corriqueira em inúmeras peças teatrais e no cinema: Diogo deveria bater na atriz. A opressão entre os sexos, que normalmente culmina no abuso físico, na família formada por Rosa e Gregório dá-se por outra via, como mostra da dissolução de um dos traços essenciais dos relacionamentos afetivos das últimas décadas: a confiança no outro, da qual depende a colaboração e a comunicação entre o casal. Esses sintomas constituem as imagens da tensão emotiva característica da metrópole labiríntica, da "cidade de terrível noite no deserto, ou, com ironia mais erudita, a tour abolie, o alvo da procura que não está lá" ${ }^{174}$, que se reproduz no ambiente familiar da protagonista, Por isso, do mesmo modo que o enredo de Longa jornada noite adentro "encerra-se como começou", isto é, "sem que quaisquer acontecimentos assinalem um caráter marcante ou especial da ação”, Rosa e Gregório, como os Tyrones, também levam consigo "as mesmas culpas e temores que continuarão a assombrá-los indefinidamente." ${ }^{175}$

\subsection{2.'Uma bruxa seduzindo o tempo'}

\footnotetext{
${ }^{174}$ FRYE, Northrop. Anatomia da crítica. Op.cit., p. 234.

${ }^{175}$ BETTI, Maria Silvia. Prefácio. In: O’NEILL, E. Longa jornada noite adentro: drama em 4 atos. Tradução Helena Pessoa. São Paulo: Peixoto Neto, 2004, p. 27. (Os grandes dramaturgos)
} 
A comédia Arlequim polido pelo amor (Arlequin poli par l'Amour), do escritor francês Pierre de Marivaux, ocupa uma posição importante na caracterização das relações com as figuras masculinas amadas por Rosa, em especial a de Diogo. A peça de 1720, escrita nos moldes da Commedia dell'arte italiana ${ }^{176}$, traz a personagem arquetípica de um Arlequim, raptado enquanto dormia por uma Fada, que se encantara com a beleza do jovem rapaz. Arlequim é apresentado como um 'menino' aparentemente imbecil, ingênuo e sem o refinamento adequado a alguém que frequenta a corte da Fada e que ela deseja tomar por esposo. Essa feiticeira, apaixonada, sugere-lhe aulas de dança, mas Arlequim, que parece ignorar o sentimento da Fada, encanta-se com um anel usado por ela. Quando a Fada, Arlequim e o criado Trivelin assistem à apresentação de uma trupe de dançarinos e cantores no palácio, com o intuito de divertir o belo jovem, este não consegue apreciar tal apresentação, demonstrando, com gestos e postura descontraída, seu descontentamento e revelando que deseja apenas comer e divertir-se. A Fada, decepcionada, dá ordens a Trivelin que lhe ofereça o que comer e que ele possa passear onde deseja, realizando todos os seus desejos e cercando-o de cuidados. Durante o passeio pelo campo, Arlequim encontra a pastora Silvia, uma moça simples, com quem trava um diálogo. Ambos se apaixonam e, a partir desse encontro, o amor terá papel fundamental no 'polimento' do desajeitado Arlequim, que leva para o palácio da Fada um lenço de Silvia para dela recordar-se. A Fada desconhece as maneiras educadas apresentadas repentinamente pelo Arlequim e espanta-se com a pergunta que ele lhe fizera: "Senhora, queira ter a bondade de me dizer como é quando se ama muito

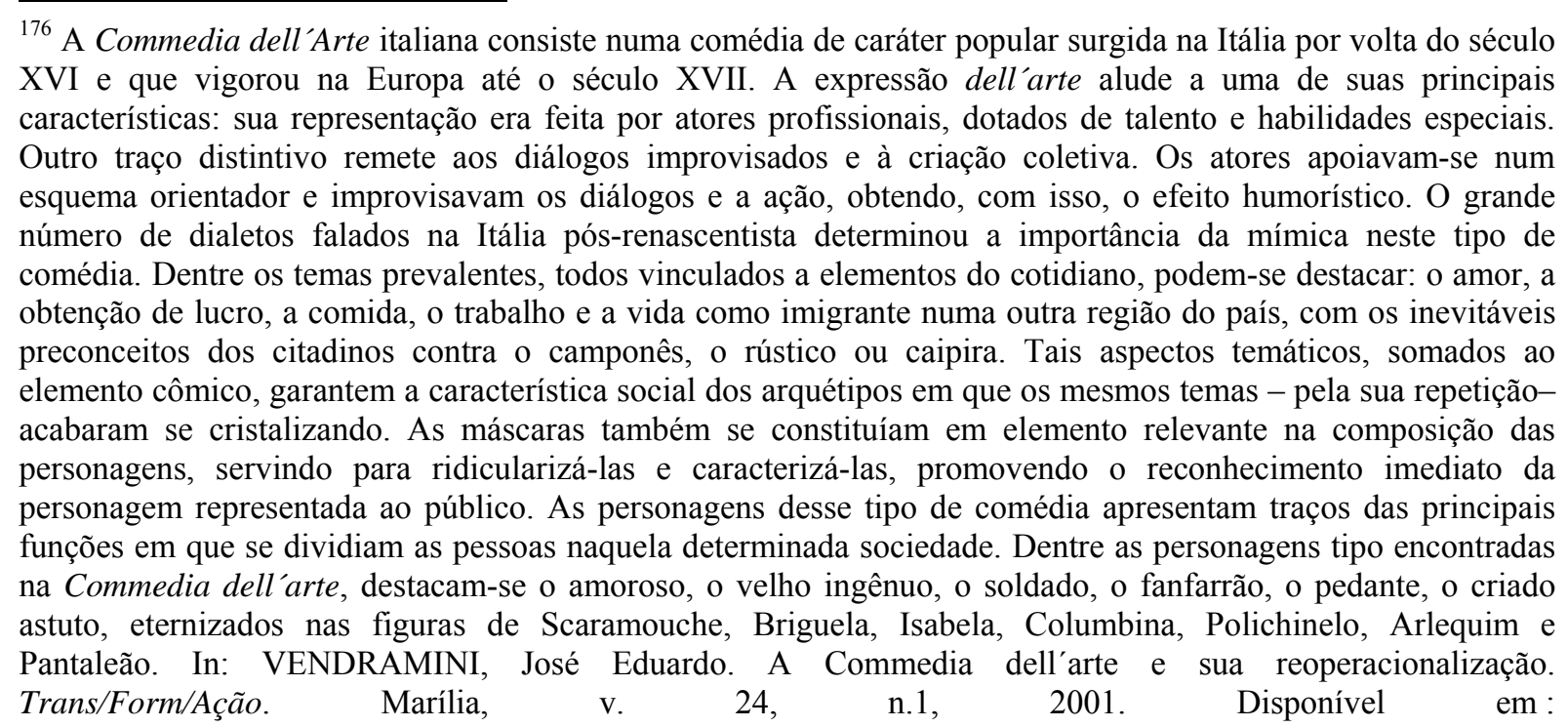
$<$ http://www.scielo.br/scielo.php?script=sci_arttext\&pid=S0101-31732001000100004\&lng=en\&nrm=iso $>$. Acesso em : 28 Jan. 2009. doi: 10.1590/S0101-31732001000100004. 
uma pessoa?" $" 177$ Arlequim pula de felicidade ao perceber que a descrição presente na resposta dada pela Fada corresponde ao sentimento que ele nutre por Silvia; diante de tal mudança de comportamento e devido à presença do lenço em poder do amado, a Fada desconfia que está sendo traída; posteriormente, flagra um novo encontro do apaixonado casal. A feiticeira ordena que Arlequim volte com ela ao palácio e, tocando em Silvia, torna-a incapaz de se deslocar, feitiço depois quebrado por uma trupe de duendes que passava pelo prado onde a pobre pastora se encontrava. A Fada manda chamar Silvia no palácio e a obriga a dizer a Arlequim que mentira sobre o amor que sente pelo jovem rapaz, ameaçando-a com a possibilidade de fazê-lo sofrer; mas vendo-o chorar, Silvia desmente o que diz. Com seus poderes de feiticeira, a Fada faz Trivelin usar seu anel que torna invisível quem o utiliza para fazê-lo capaz de ouvir, sem ser visto por Arlequim, a conversa entre Silvia e o jovem. No entanto, o criado fiel a Merlin, o mágico que ama a Fada e que deseja esposá-la, aparece e oferece sua ajuda ao jovem casal, dizendo à Fada que Silvia confirmara ao jovem Arlequim que tudo se tratava de mentira. Este último finge amar a Fada e, seguindo o plano de Trivelin, sutilmente a engana raptando, de forma brincalhona, sua poderosa vara, impedindo-a de colocar quaisquer obstáculos ao relacionamento do jovem casal.

Arlequim Polido pelo Amor, além dos elementos característicos da comédia ${ }^{178}$, apresenta alguns aspectos que remetem às histórias romanescas, característicos de diversas peças da commedia dell'arte, da qual Marivaux é herdeiro. A atmosfera da peça evoca um mundo idealizado, em que não faltam as imagens do jardim e do prado, onde se dão os castos encontros amorosos de Arlequim e Silvia, as das ovelhas e cordeiros sob o comando da jovem pastora, e nem mesmo a de uma varinha de condão e de um anel com poderes mágicos, pertencentes à Fada. A presença de tais imagens corresponderia à "tendência de sugerir padrões míticos implícitos num mundo mais estreitamente associado com a experiência humana" ${ }^{179}$ pelo processo de deslocamento das estruturas míticas, ligadas ao mundo dos deuses, em direção ao mundo dos homens. Para dizer com Frye, aquelas imagens representam

\footnotetext{
${ }^{177}$ Tradução minha a partir do francês: "Madame, voulez-vous avoir la bonté de vouloir bien me dire comment on est quand on aime bien une personne?". In: MARIVAUX, P. Arlequin poli par l'amour. In: Théatre Complet. Préface de Jacques Scherer. Aux Éditions Du Seuil. Paris, 1964, p. 61.

${ }^{178}$ O enredo básico da Comédia Nova grega tornou-se a base da maior da comédia que até hoje conhecemos, segundo Frye. Na comédia, um jovem aspira a uma jovem, mas seu desejo é contrariado por algum tipo de oposição, normalmente paterna. No início, os obstrutores dominam a sociedade da peça e "os obstáculos ao desejo do herói formam a ação da comédia, e sua superação, o desenlace cômico". Perto do fim, ocorre uma reviravolta no enredo que normalmente reúne herói e heroína e faz uma nova sociedade se cristalizar em torno desse casal. O momento em que essa cristalização ocorre é o da revelação cômica, conhecida por anagnórisis ou cognitio e constitui o arquétipo da comédia. FRYE, Northrop. Anatomia da crítica. Op.cit., p.163-164.
}

${ }^{179}$ FRYE, Northrop. Anatomia da crítica. Op cit.,p. 141. 
uma "contrapartida humana do mundo apocalíptico" $" 180$, que o crítico canadense denomina analogia da inocência. A associação da figura do Arlequim à de um 'menino' remete evidentemente à infância, que, juntamente com a castidade, constituem as metáforas da inocência por excelência. A estrutura da comédia, ligada ao mythos da Primavera, diz respeito ao triunfo da fantasia, em que "os finais felizes não nos impressionam como verdadeiros, mas como desejáveis, e concretizam-se por manobra"181, que na peça de Marivaux conta com o auxílio providencial do criado Trivelin, que garante a vitória de Silvia: sua sugestão faz o feitiço virar literalmente contra a feiticeira, permitindo a inversão dos padrões sociais, em que a Fada, superior em poder, é substituída, na preferência do Arlequim, pela humilde e ingênua pastora.

Em As Horas Nuas, Diogo mostrara a Rosa uma foto em que está vestido de arlequim, quando participou de uma festa de carnaval na infância. O retrato desencadeia a lembrança da peça de Marivaux e leva Rosa Ambrósio a associar a figura do menino, presente na imagem, com a docilidade pueril do Arlequim da peça francesa. É importante destacar que a atriz refere-se a Diogo, por vezes, pela expressão 'menino de coração contente', que achava 'graça' na vida, e confere a si mesma e ao amante o atributo 'fantasioso': "Fantasioso o meu menino, meu menino Diogo, não tem importância, eu também sou fantasiosa, dois fantasiosos cheios de fantasia" (HN, p. 199). Na Commedia dell'Arte, o Arlequim, como personagem tipo, é simples, ingênuo, alegre, normalmente faminto, pobre e fisicamente atraente, características que, de certo modo, mantêm uma relação de proximidade com a personagem do gigolô de As Horas Nuas, uma vez que Rosa o vê assim, embora ele nem sempre apresente esses atributos. No entanto, o mecanismo do qual Rosa se utiliza para estabelecer a associação entre a figura de Diogo e a personagem do Arlequim é o mesmo utilizado por ela quanto ao seu próprio revestimento por máscaras, pelas inúmeras personagens por ela vividas nos palcos.

$\mathrm{Na}$ personagem do Arlequim, Rosa encontra, portanto, semelhanças com a figura de Diogo e o reveste com essa persona que, por sua vez, encobre a de Miguel. Considerando as observações feitas por Rahul e algumas recordações da protagonista sobre o amante, nas quais ele tem voz, pode-se dizer, no entanto, que a figura de Diogo, a cujo nome, de origem latina, atribuem-se os significados de 'instruído', 'belo', 'conselheiro', 'pessoa dotada de forte magnetismo e muita capacidade de liderança', remete a Apolo, o deus da luz solar, da inteligência, da música e da poesia. O amante reúne, do ponto de vista de Rosa, os atributos

\footnotetext{
${ }^{180}$ FRYE, Northrop. Anatomia da crítica. Op cit.,p. 152.

${ }^{181}$ Ibid., p.170 - grifo meu
} 
físicos como o corpo atlético, a expressão calma, o 'bom conselho', características também associadas ao deus grego. É ele quem indica o sentido da luta e afirma que a atriz é a primeira a se limitar, a afastar-se do trabalho e também das pessoas e por isso constitui-se no símbolo do "autodomínio no entusiasmo, da aliança entre a paixão e a razão"182. Ama a luz e o jazz, com seus saxofones, e transforma o gosto por este tipo de música como uma forma de manter contato com a figura materna, que abandonara o filho e o esposo para fugir com um homem que tocava o mesmo instrumento musical.

O amante recusa-se ao "jogo do faz de conta" a que Rosa se submeteu, mostrando-lhe que seu afastamento dos palcos, das pessoas e o ódio que sentia por si mesma tinham suas origens no medo de envelhecer e de ser esquecida; Diogo apontava seus defeitos e vícios, sem as bajulações às quais ela estava acostumada, mas também não escondia a sete chaves a existência de suas amantes, “(...) uma borboleta mas fiel nas suas infidelidades, à sua moda ele me amou" (HN, p.143), afirma a atriz. É ele quem tenta fazê-la pisar com os dois pés no chão, apontando sua condição de mulher rica num país de miseráveis e esforçando-se em ensinar Rosa a 'transformar depressão em ação'; por essa razão, sua posição remete às imagens comuns da experiência, que tem no "redescobrimento da fé por intermédio das obras" $" 183$, do trabalho, seu elemento estrutural.

Diogo se refere à atriz como seu espelho deformante, com todas as conotações de decadência ligadas ao envelhecimento e à depressão. No amante, entretanto, Rosa via-se perfeita porque nele sentia que tinha 'o tempo diante de si' ${ }^{184}$, a negação da morte. A velha atriz é, segundo Rahul, "uma bruxa seduzindo o tempo" (HN, p. 99), como a mitológica figura de Circe, e encontra uma solução antiga para a mulher, só que com o sinal trocado: agora é ela quem bebe na 'fonte da juventude' de um ser mais jovem, recurso tradicionalmente usado pelos homens. Nas palavras de Beauvoir, a mulher envelhecida voltase para os rapazes porque "é deles somente que pode esperar essa ternura desinteressada que o adolescente experimenta por uma amante maternal”"185. Rosa só consegue imaginar qualquer possibilidade de vida nova atrelada unicamente à presença desse jovem, consciente de que

\footnotetext{
${ }^{182}$ CHEVALIER, Jean ; GHEERBRANT, Alain. Dicionário de símbolos. Op.cit., p. 67.

${ }^{183}$ FRYE, Northrop. Anatomia da crítica. Op.cit., p. 155

${ }^{184}$ Mais uma vez, a semelhança de Rosa com Luisiana, do conto já mencionado, é patente: "Quero deixar bem claro que a única coisa que existe para mim é a juventude, tudo o mais é besteira, lantejoula, vidrilho. Posso fazer mil plásticas e não resolve, no fundo é a mesma bosta, só existe a juventude. Ele era minha juventude mas naquele tempo eu não sabia (...). TELLES, Lygia F. Apenas um saxofone. In: Antes do baile verde. Op.cit., p. 36.

${ }^{185}$ BEAUVOIR, Simone de. O segundo sexo. Op.cit., p. 765.
} 
continuará a ser enganada por ele, sem deixar de lado um certo humor negro, revelando aparentemente um retrocesso frente a todas as conquistas por ela obtidas ao longo da vida, como sucesso profissional e independência econômica, esta última agora a serviço dos caprichos de Diogo: "Abro a bolsa e a vida, Leva o que quiser, querido. Caixão não tem gaveta, lembra?" (HN, p. 199). ${ }^{186}$

A postura de Rosa com relação ao amante é semelhante à da Fada com o Arlequim: Rosa, detentora de um poder econômico considerável, sustentava o alto padrão de vida de Diogo. Quem assume o papel de mantenedor econômico do companheiro não é mais a figura masculina: isso agora fica a cargo de Rosa, o que delineia inclusive a relação de poder que ela exerce sobre o amante. Mais uma vez, invertem-se os papéis tradicionais normalmente atribuídos às personagens femininas e masculinas, evidenciando não só uma projeção em Rosa da necessidade de assumir o lugar do pai como mantenedora, mas também a transformação nas maneiras de pensar num período de aproximadamente quarenta anos, frente à desestabilização de comportamentos tidos especificamente como de homem e de mulher.

É interessante notar nesta peça, assim como em outras comédias de Marivaux, que as personagens masculinas perdem o brilho diante das figuras femininas, as quais estão nos papéis principais. No entanto, no que se refere à peça do escritor francês, Rosa não realiza nenhuma associação de si mesma com a Fada ou com Silvia, mas sim de Arlequim com Diogo. Ora, em se tratando de uma personagem que mantém seus segredos mais recônditos guardados a sete chaves, não surpreende o fato de que Rosa tenha ocultado sua semelhança com a Fada, no que concerne ao seu desejo de reconquistar o amante, utilizando-se do seu grande poder econômico, assim como a Fada fez uso de sortilégios, de um anel mágico e de uma vara de condão para garantir a conquista almejada, embora sem sucesso. Na ausência de poderes sobrenaturais, o dinheiro cumpre a função de realizador dos desejos e, nesse sentido, é notória sua semelhança com a Fada. Assim, fica patente a sugestão de que a velha atriz deseja um desfecho para sua história com Diogo semelhante ao de Arlequim Polido pelo Amor que, no entanto, dar-se-ia, mais uma vez, às avessas: feitas as aparentes 'pazes' com seu próprio corpo, o próximo passo consistiria na aceitação da infidelidade do amante e da manutenção de seu estilo de vida burguês em troca de sua companhia, já que a solidão se afigura como algo insuportável para a atriz. Diogo passaria, então, à condição de 'amante-

\footnotetext{
${ }^{186}$ De modo semelhante, Luisiana, protagonista de 'Apenas um saxofone', também admite em seu monólogo que estava consciente de que era enganada por aqueles que dela se aproximavam, com o objetivo de lhe arrancar dinheiro, mas diferentemente de Diogo em relação à Rosa Ambrósio, o sensível saxofonista que a amava vivia na mais completa simplicidade.
} 
irmão': “(...) deite-se com suas meninas de peitinhos duros e bundinha dura que prometo não interferir mais, quero apenas a sua companhia, entendeu, Diogo? A sua fala, o seu riso, a sua graça. A sua música e a sua angústia (...)” (HN, p. 199). O ciúme da atriz, que a leva a expulsar o amante de seu apartamento, dá lugar à mais profunda resignação e ao desejo de viver, com Diogo, o romance que não conheceu com Miguel.

Nesse aspecto, é possível notar semelhanças entre Rosa Ambrósio e a protagonista do conto "Boa noite, Maria". Maria Leonor, uma mulher de sessenta e cinco anos e economicamente abastada, encontra no finlandês viúvo que lhe oferecera ajuda com as malas em um aeroporto o companheiro ideal- não um marido ou amante, mas um amigo- para ajudála a vencer a solidão e o medo da morte, que teme se aproximar. Os pensamentos de Maria são trazidos à tona pelo narrador onisciente neutro enquanto Julius vai chamar um táxi e, dessa forma, o leitor tem acesso aos planos de Maria sobre o futuro com esse desconhecido, dentre eles, o de que o companheiro, quando chegasse a hora, ajudar-lhe-ia a 'sair de cena' num dia comum, depois da costumeira visita noturna, seguida de uma taça de vinho, sem que ela percebesse. Com esse companheiro, que passa a morar em seu apartamento, ela descobre o amor maduro e o próprio corpo, sem o compromisso de um casamento propriamente dito; embora ocupem pisos diferentes da cobertura triplex de Maria, a visita noturna de Julius permite que eles cultivem um relacionamento marcado pela amizade e cumplicidade e desfrutem de momentos agradáveis, sem cobranças nem exigências quanto ao corpo que envelhece, por exemplo. Diante do agravamento da doença da companheira, Julius lhe dá a maior prova de seu amor: realiza a velada eutanásia, numa cena de ternura singular, em que o sofrimento de Maria Leonor esvai-se, diluído no vinho mortal, depois do derradeiro "Boa Noite", tendo sua cabeça apoiada pelas mãos fortes do amado que, segundo ela, lhe trouxera de volta a infância.

A semelhança entre Rosa e Maria Leonor nas questões que envolvem o amor entre uma mulher mais velha com um homem mais jovem pauta-se na possibilidade de vencer a morte e a solidão - conotações associadas ao envelhecimento - e isso se coaduna com a ideia de 'paraíso perdido' tão cara a Rosa Ambrósio. Por essa razão, o desejo de relacionamento da atriz com Diogo, que deixaria de estar pautado em sexo, consistiria, aparentemente, em uma espécie de retorno à inocência, sugerida, tal qual a Roda da Fortuna, no movimento cômico ascensional "das complicações ameaçadoras" vividas por Rosa para um "final feliz" com esse amante. Isso se expressa na "visão do fim do esforço social, o mundo inocente de desejos 
satisfeitos, a sociedade humana mais livre"187, que é o mito central da arte para Frye, formas universais recuperadas por Lygia na construção da vida imaginativa de sua protagonista, através da desejável passagem do aspecto trágico para o cômico, com a reintegração de Rosa à sociedade e à nova família a ser formada com Diogo.

Embora a atriz tente dar um revestimento ficcional de contos de fada à projeção de um futuro em aberto, demonstra que isso provavelmente ficará no plano do desejo. A razão de fundo desse obstáculo sexual que Rosa impõe como condição à pretensa nova etapa de vida com Diogo encontra-se, mais uma vez, no relacionamento narcísico que a atriz tem consigo mesma. O descontentamento com seu próprio corpo, incitado pelo avanço da idade, leva a protagonista a desejar não existir para o amante; quer conservar apenas o prazer visual que a imagem de Diogo lhe proporciona. Considerando as observações de Beauvoir ${ }^{188}$, na medida em que Rosa só se sente amada quando seduz, a imagem desfavorável que ela agora tece de seu próprio eu transforma-se, portanto, em impedimento às relações sexuais. Como em matéria de amor a mulher é geralmente mais narcisista que o homem e seu "narcisismo visa o corpo todo", prolonga-se sua condição de objeto erótico. ${ }^{189}$

O mythos total da comédia assenta-se no fato de que "a sociedade do herói rebela-se contra a sociedade do senex e triunfa, mas a sociedade do herói é uma Saturnal, uma inversão dos padrões sociais que lembra uma idade de ouro no passado, antes de a ação principal da peça ter início"190. Ou seja, a 'fábula' da comédia abrange as fases de equilíbrio, desequilíbrio e novo equilíbrio ${ }^{191}$. Por essa razão, no processo da suposta metamorfose de Rosa, Arlequim Polido pelo Amor representa um divisor de águas: perceber-se no papel da feiticeira, cuja representação a Fada encerra, significa para Rosa estar associada ao lado feio da vida, a uma parte do passado obscuro que deseja esquecer, no qual inclui a ambição que pautou sua vida e a chegada da velhice. Por outro lado, equiparar-se a Silvia, em seu padrão de bondade, ingenuidade e inocência, além de remeter ao período em que foi Rosinha, é também a nova etapa que a atriz deseja viver, uma tentativa de restabelecer a 'idade de ouro' da adolescência, na qual figuraria apenas a porção bela das coisas, as horas tidas como claras que passaria a viver na companhia de Diogo. Apesar dessa tentativa, é patente que Rosa continuará atuando

\footnotetext{
${ }^{187}$ FRYE, Northrop. Fábulas de identidade- Estudos de Mitologia Poética. Tradução Sandra Vasconcelos. São Paulo: Nova Alexandria, 2000, p.25.

${ }^{188}$ BEAUVOIR, Simone de. A velhice. Op.cit., p. 50.

${ }^{189}$ Ibid., p. 83.

${ }^{190}$ FRYE, Northrop. Anatomia da crítica. Op.cit., p. 171.

${ }^{191}$ PAVIS, Patrice. Dicionário de Teatro. Op.cit., p. 53.
} 
no papel dúbio de feiticeira e pastora: se Rosa assemelhava-se a Silvia, na juventude, em sua inocência, com o passar do tempo, a atriz entra definitivamente no mundo adulto da Fada, lançando mão de estratégias calcadas no seu amplo poder aquisitivo para lidar com essa situação. De acordo com tais observações, pode-se dizer que a projeção que Rosa faz de seu futuro com Diogo possivelmente tomará um rumo oposto, pois parece caminhar novamente para "as configurações míticas da experiência, as tentativas de dar forma às ambiguidades e complexidades da existência não idealizada", isto é, em termos de estrutura, surge associada a uma "paródia da estória romanesca", à "aplicação de formas míticas romanescas a um conteúdo mais realístico, que as amolda em direções imprevistas" ${ }^{\text {192 }}$, justamente porque o conjunto de imagens que acaba funcionando como paródia da idealização da vida alude às situações comuns e típicas do cotidiano, mais uma vez evitadas pela protagonista.

Mesmo desejando uma nova vida com o amado, ela continuará sustentando seu estilo de vida, fingindo, desta vez, desconhecer as prováveis amantes com as quais ele a trairia, o que, de certo modo, reproduz, na figura de Rosa, a dependência amorosa de Diogo como outra espécie de 'servidão' da mulher. No entanto, se os desejos de controle do destino individual e os desejos de entrega emocional aparecem conjugados na construção do feminino como o caminho para a realização plena da mulher ${ }^{193}$, como ocorre com Rosa Ambrósio, isto se dá porque o "amor continua a ser uma peça constitutiva da identidade feminina."194

\subsubsection{Entre céu e inferno}

A ironia presente na avaliação das duas personagens masculinas evidencia, mais uma vez, as representações que a protagonista faz do esposo, do amante e de si mesma e aquelas que se concretizam aos olhos do leitor. Gregório e Diogo são duas metades, senão opostas, complementares - lua e sol, frio e calor, espírito e matéria, feminino e masculino, respectivamente-, das quais Lygia lança mão para revelar os papéis desempenhados por Rosa no espaço privado da vida doméstica como esposa e amante: “(...) uma mulher comum. Com as mesmas inquietações e os mesmos problemas" (HN, p. 14), "uma frágil mulher cheia de carências e aparências" (HN, p. 12). Sandra Almeida chama a atenção para a afirmação de

\footnotetext{
${ }^{192}$ FRYE, Northrop. Anatomia da crítica. Op.cit., p. 219.

${ }^{193}$ LIPOVETSKY, Gilles. A terceira mulher. Op.cit. p. 32-33.

${ }^{194}$ Ibid., p.32.
} 
Renato Medrado, primo de Ananta, ao final do romance, de que Rosa Ambrósio é "um ser solar", que tem "o sol dentro dela", e a resposta reticente de Dionísia, que "enfatiza a ironia da declaração" 195 . Para a autora, "Rosa é a incorporação da lua com suas qualidades femininas e passivas"196, já que se distancia da representação tradicional do sol, a saber, do poder masculino, da autoridade e da fertilidade, esta última na acepção oposta de castração, que caracteriza a abstinência sexual a que a protagonista se submete ${ }^{197}$. O sol, como vimos, transformara-se no 'inimigo' da protagonista, representado no formato do espelho que refletiu o beijo usurpador. A fonte de energia que iluminava o jovem casal Rosa e Gregório, que andava de mãos dadas e vivia numa "felicidade insuportável" (HN, p. 108) no início do casamento, tem sua luz progressivamente apagada; para disfarçar a traição feita por membros de sua intimidade, Rosa passa a buscar, portanto, outra figura capaz de lhe dar calor, diante das queixas de frio por ela sentido: basta falar em Miguel, mas também em Diogo, para que sua voz fique "mel e sol”, doce, quente e amarela como sugere a própria adolescência:

na mentira a minha cara virava uma romã vermelha, lustrosa. Amarelecia no medo, isso na adolescência. Agora fiquei amarela definitivamente, não interessa, ainda estou lá longe com aquele Miguel charmoso e desambicioso. Miguel, o Louro. Miguel, o Breve. (HN, p. 205-grifo meu)

Embora simbolicamente a terra esteja associada ao princípio passivo e o céu ao principio ativo, Gregório, ligado à representação do céu, deixa transparecer em seu comportamento com Rosa e a filha conotações assimiladas mais estreitamente ao caráter feminino que o símbolo da terra encerra, em seu papel de rocha, que sustenta com doçura e firmeza as trapalhadas da esposa, corroborado pelo simbolismo da lua, paixão do físico; Diogo, ligado à terra, por sua vez, é dotado de características reconhecidamente masculinas, caráter mais pragmático simbolizado pelo céu e reforçado pelo sol, no que concerne ao papel ativo que exerce sobre a protagonista. Entretanto, a imagem de aparente passividade e atividade dessas personagens é desconstruída pela posição política com a qual Lygia, como escritora, insufla ambas as personagens. É na "fúria da rebelião" presente em Gregório que se torna mais evidente sua ligação com o céu, simbolizado pela associação com o mundo

\footnotetext{
195 ALMEIDA, Sandra R.G. Castration and melancholia in Lygia Fagundes Telles' As Horas Nuas. Op.cit., tradução minha.

${ }^{196}$ Ibid. Tradução minha. Almeida também estabelece Rahul como espelho de Rosa, em sua identificação com a lua: "A noção de que o gato incorpora características femininas através de sua relação com a lua pode explicar a associação próxima de Rahul com Rosa e o espelhamento que dela faz" (tradução minha). No capítulo 4, analisarei mais detalhadamente essas questões, nas quais distingo inclusive a associação entre Rahul e Gregório. ${ }^{197}$ Ibid..
} 
espiritual; e é na falta de uma posição verdadeiramente atuante em Diogo, que só podia fazer uso de um discurso hipócrita e reacionário, que se mostra sua ligação com a terra, simbolizada pelas preocupações estritamente materiais. Desse modo, a variável identificação que os símbolos encerram torna perceptível o caráter nada maniqueísta da identidade dessas personagens lygianas e, deste modo, põe em evidência o aspecto cultural que envolve a construção dos gêneros, na medida em que desconstrói representações masculinas e femininas preestabelecidas.

Assim, na relação da protagonista com as figuras masculinas com quem estabeleceu sentimentos amorosos, existe a concepção subjacente de movimento cíclico, com a alternância de êxito e declínio, vida e morte. No mundo dolorosamente humano de Rosa, esse movimento é representado justamente como o ciclo imaginativo da vida acordada e da onírica, paralelo ao ciclo solar de luz e trevas, a antítese entre a imaginação da experiência e a da inocência ${ }^{198}$, entre as diversas representações dos princípios masculino e feminino da cultura - Miguel, Gregório e Diogo. Pelas razões expostas, a fuga de Rosa para o romântico e para o imaginário enquanto espera a volta de Diogo encontra eco na personagem da "moça apaixonada pelo amante que não voltou", papel teatral que a atriz deseja desempenhar, às escondidas, com o gato Rahul. Essa jovem é protagonista de uma peça assistida por Rosa em Paris, juntamente com Gregório, cujo olhar dizia à esposa que estava velha demais para continuar a atuar como uma mocinha romântica e ingênua. Sua vontade de reencontrar o amante é semelhante ao desejo da personagem do conto popular português "A noiva do Corvo", mencionado pela atriz, que calça sapatos de ferro e sai pelo mundo em busca do amante ${ }^{199}$. Camuflados na visão de inocência e fantasia dessa história, encontra-se o estereótipo da felicidade conjugal, expresso na dicotomia atividade x passividade. Nesse modelo, cabem à figura masculina atributos como forte, poderoso, protetor; à figura feminina, a fragilidade, a dependência e proteção no que se refere ao homem. Para a mulher, as escolhas estão condicionadas ao atendimento das expectativas da figura masculina, mesmo em "A noiva do Corvo", no qual, apesar de demonstrar características de atividade, estas se dão em função de encontrar o bemamado, transformá-lo em ser humano para depois a ele sujeitar-se. Isso demonstra, mais uma vez, que na atriz coexistem características compatíveis com o delineamento de seu perfil

\footnotetext{
${ }^{198}$ FRYE, Northrop. Anatomia da crítica. Op.cit. p. 160.

199 Cabe destacar que no referido conto português, a jovem sai em busca do esposo, um corvo que fugira. Rosa, que ouviu a história do pai, quando criança, usa a expressão amante, o que revela como os fragmentos da memória sofrem o efeito do distanciamento no tempo e são retrabalhados em favor de sua própria situação atual.
} 
como correlativo ao de 'terceira mulher' ${ }^{200}$ e valores patriarcais fortemente arraigados, como a referência à superioridade masculina, frente à qual se estabelece a passividade feminina.

Assim como o universo do teatro é a metáfora da representação em As Horas Nuas, Diogo, ligado ao mundo de Apolo, representado pelas faculdades solares da reflexão, do juízo e da vontade ${ }^{201}$, é também o símbolo da eterna juventude, a alegoria do dia sempre novo e que renasce $^{202}$ na visão da protagonista. Nessa última acepção, Apolo é associado a Dioniso e, nesse sentido, Diogo é tido como o complemento de Rosa Rosae, simbolizada pelas faculdades lunares de imaginação, sentimento e percepção ${ }^{203}$, e associada ao mundo dionisíaco em suas mais diversas acepções: teatro, embriaguez, loucura. Segundo Chevalier,

no sentido mais profundamente religioso, o culto dionisíaco, a despeito das suas perversões e, mesmo, através delas, testemunha o violento esforço da humanidade para romper a barreira que a separa do divino, e para libertar sua alma dos limites terrenos. Os excessos sexuais e a libertação do irracional são apenas buscas desastradas de alguma coisa sobre-humana. Por paradoxal que isso pareça, Dioniso, considerando o conjunto de seu mito, simbolizava o esforço de espiritualização da criatura viva desde a planta até o êxtase: (...) ele sintetiza (...) toda a história de uma evolução. ${ }^{204}$

Dioniso, como símbolo ambivalente, está associado à figura de Rosa no que concerne à ruptura das inibições e das repressões - "uma submersão da consciência no magma do inconsciente" ${ }^{205}$. Ele simboliza as forças obscuras que surgem do inconsciente; é o deus dos excessos provocados por toda espécie de embriaguez, até mesmo a da loucura, que "ele inspira àqueles que não o honraram como convém”, como sugere a apropriação das características de Martha por Rosa, por exemplo. A aproximação da protagonista com a loucura, ao longo do romance, evidencia-se na evocação do passado e permite, até certo ponto, o exorcismo dos 'fantasmas' que a perseguem. Como revela o final de Quem tem medo

\footnotetext{
${ }^{200}$ Terceira mulher é a denominação que Gilles Lipovetsky dá à figura sócio-histórica surgida na sociedade contemporânea que se encontra em um mundo aberto, estruturado por uma "lógica de indeterminação social e de livre governo individual, análoga em seu princípio à que organiza o universo masculino" que, no entanto, não preconiza o fim das 'assimetrias dos gêneros' e da divisão social dos papéis de sexo. LIPOVESKY, Gilles. A terceira mulher. Op.cit., p.12.

${ }^{201}$ CIRLOT, Juan-Eduardo. Dicionário de Símbolos. Op.cit., p.537.

202 GRAZIANI, Françoise. Apolo, o Sol Mítico. In: BRUNEL, Pierre (org.). Dicionário de mitos literários. Tradução Carlos Sussekind et al. 4.ed. Rio de Janeiro: José Olympio, 2005, p.67.

${ }^{203}$ CIRLOT, Juan-Eduardo. Dicionário de Símbolos. Op.cit., p. 537.

${ }^{204}$ CHEVALIER, Jean; GHEERBRANT, Alain. Dicionário de símbolos. Op.cit., p. 341.

${ }^{205}$ Ibid., p. 341.
} 
de Virginia Woolf?, os rótulos foram rasgados, metaforicamente representados nas garrafas de conhaque desnudadas por Honey, levando as personagens a chegarem ao osso, 'ao tutano', como o último jogo de George conseguiu realizar. Em As Horas Nuas, esse mesmo processo de desnudamento ocorre efetivamente apenas com a protagonista, uma vez que todos os envolvidos 'saíram de cena', cada um a seu modo, no presente da narrativa, e só adquirem seus verdadeiros lugares ou assumem novas configurações no plano das memórias que a atriz deseja escrever. Nelas, Rosa Ambrósio tentará um reencontro com a própria infância, uma possibilidade de recuperação dos longos anos vividos, um modo de prolongar o tempo que se encurta à sua frente: o desejo de vencer a estagnação e a morte, que também é, guardadas as devidas proporções, o desejo de Rahul e Ananta. 
contranarciso

em mim

eu vejo o outro

e outro

e outro

enfim dezenas

trens passando

vagões cheios de gente

centenas

o outro

que há em mim

é você

você

e você

assim como

eu estou em você

eu estou nele

em nós

e só quando

estamos em nós

estamos em par

mesmo que estejamos a sós

(叉aulo Eeminski - Oaprichos e relaxos) 


\section{AS OUTRAS DIMENSÕES DO ESPELHO}

espelho é considerado um símbolo da imaginação ou da consciência, capaz de
reproduzir, em seu aspecto formal, os reflexos do mundo visível, o qual, como descontinuidade afetada pela lei da mudança e da substituição, projeta o sentido negativo do espelho, o do caleidoscópio de aparecer e desaparecer que ele reflete ${ }^{206}$. No sentido aqui exposto, a metáfora do espelho é a que melhor caracteriza as relações entre Rosa e as demais personagens do romance. Com suas propriedades refletoras, pode exibir o reflexo da imagem que nele se projeta, revelando o ser e o não-ser das mulheres e homens que circulam pelo prédio onde moram Rosa, seu gato e Ananta. A velha atriz vive cercada deles - sejam os de aumento, que ela esconde para não ver amplificados os "estragos" causados pela passagem do tempo, ou ainda aqueles distribuídos ao redor da casa, como na sala repleta deles. São os espelhos humanos, no entanto - Dionísia ${ }^{207}$, Ananta e Rahul - que oferecem reflexos importantes da protagonista, o contraponto necessário para compor, com suas diversas faces, o mosaico caleidoscópico Rosa Ambrósio.

\section{2. “Expor se escondendo"}

Desde criança ela sempre gostou do jogo-sem-nome que consistia apenas em rondar o alvo desejado (e quanto!) mas sem a menor pressa em atingi-lo. (...) Deixar crescer a expectativa retardando o instante de cravar os dentes na maçã escondida no bolso da calça, a maçã ficava no fundo desse bolso. $\mathrm{O}$ encanto estava em circular com naturalidade sem levantar suspeita, o prazer (maior) estava nisso, em se expor se escondendo. (...) A paciência em esperar pela hora propícia amadurecida no escuro. Ousar (com coragem) a alegria proibida. Proibida? Voltou-se bruscamente para a janela com suas cortinas caindo retas, do mesmo tom castanho-claro do tapete. Havia sol lá fora mas o tecido compacto permitia apenas a passagem de uma luz discreta. Opacidade. Quietude. Por que proibida? Essa alegria. Onde estava a transgressão se a janela (ou a fruta ou o doce) lhe pertencia, pois não

\footnotetext{
${ }^{206}$ CIRLOT, Juan-Eduardo. Dicionário de Símbolos. Op.cit., p. 239.

207 A empregada Dionísia, como espelho da protagonista, já foi analisada no capítulo anterior. Aqui, discuto a função de espelho verdadeiro e às avessas que Rahul e Ananta se constituem respectivamente para Rosa, por se tratarem de personagens que participam, juntamente com a protagonista, da multiplicidade das perspectivas narrativas do romance.
} 
pertencia? Pertencia e não pertencia. Esticou as pernas e recostou a nuca no espaldar da cadeira. Voltou para o teto o olhar atento. A respiração ficou acelerada. Curta.

-Tenho um Vizinho, anunciou e enfiou a mão no bolso, como se fosse tirá-lo dali (...). (HN, p. 71)

A analista de Rosa, Ananta Medrado, vivia solitária, numa espécie de reclusão e simplicidade, por trás da qual se escondia uma mulher que gostava do jogo de "se expor se escondendo". Sua rotina consistia basicamente em atender pacientes, esforçando-se incessantemente para “(...) não ridicularizar, não lamentar e não desprezar as ações humanas mas compreendê-las" (HN, p. 70). Além disso, como militante feminista, Ananta circulava por inúmeros espaços institucionalizados tentando oferecer algum tipo de cidadania a mulheres a quem a cidadania foi negada pela metrópole. Ela dava auxílio financeiro às creches que cuidavam dos filhos de mulheres trabalhadoras; fazia reuniões com e ajudava mulheres vítimas de todos os tipos de preconceito e violência, especialmente as que "apanhavam e se queixavam", como ironiza Rosa Ambrósio. Ananta também participava de congressos e debates acerca de questões como planejamento familiar, sexualidade e legalização do aborto, que envolviam a condição da mulher no Brasil, de acordo com a nova agenda do movimento feminista da década de 80 .

O apartamento organizado, situado no mesmo prédio onde mora Rosa Ambrósio e que também funcionava como escritório da analista, reflete seu despojamento, assim como sua apresentação pessoal revela, na imagem que tenta transmitir aos vizinhos, pacientes e colegas feministas, uma forma de afastar quaisquer pistas que possam aludir ao seu verdadeiro 'eu'. Tomado nesse sentido, o apartamento adquire conotações de concha, na medida em que remete ao emblema do ser humano completo, do corpo que "encerra num invólucro exterior a alma que anima o ser inteiro, representado pelo organismo do molusco"208. A pequena analista, cujo nome remete à expressão anã ${ }^{209}$, de comportamento discreto, vestia-se e perfumava-se também de maneira discreta; não usava esmaltes nem maquiagem. Quase tudo em sua aparência ou em seus bens materiais oscila entre a neutralidade do bege, do cinza e do castanho, claro ou escuro: o carro café-com-leite, os sapatos na cor caramelo, o tapete e as cortinas castanho-claros, a saia acinzentada, os cabelos castanho-escuros presos por uma fivela no mesmo tom. A ausência de espelhos, retratos e certificados no local ocupado por

\footnotetext{
${ }^{208}$ BACHELARD, Gaston. A poética do espaço. Tradução Antonio de Pádua Danesi. São Paulo: Martins Fontes, 1993, p.127. (Coleção Tópicos)

${ }^{209}$ ALMEIDA, Sandra R.G. Castration and melancholia in Lygia Fagundes Telles’ As Horas Nuas. Op.cit..
} 
essa investigadora do inconsciente é reveladora da dificuldade que ela tem de conhecer a si mesma e de dar-se a conhecer, surpreendendo até mesmo Rahul que descobrira, no dia da morte de Gregório, que ela também era médica. Esses elementos são pistas importantes para compreendermos a personagem que se esforça por criar uma imagem também neutra, acima de qualquer suspeita, a representação de alguém que não tinha algo a esconder. A frieza e a distância mantidas por Ananta são formalizadas na sua apresentação a partir de uma onisciência seletiva, que ora aprofunda sua análise mental, ora descreve suas ações, diferentemente do recurso ao monólogo interior de Rosa e Rahul, adotado pela autora implícita. A opção pelo distanciamento característico daquela voz narrativa permite que a focalização incida sobre o eixo central da narrativa, Rosa Ambrósio, e coaduna-se com a intenção da autora de manter o mistério que cerca o desaparecimento da personagem da analista, preservando com isso a ambiguidade. ${ }^{210}$

Comparada a Ananta, a atriz se constitui em uma representação bastante diferente: uma mulher alta, exuberante, vaidosa, que gostava de acessórios com os quais se 'mascarava', como echarpes e inúmeras jóias, sem contar a maquiagem em excesso; o apartamento de Rosa, ao contrário do de Ananta, era repleto de espelhos. O primo da analista, Renato Medrado, ao final do romance, abre uma pequena caixa que estava em uma estante e indagase sobre a semelhança do tom verde-azul intenso do olho da pena de pavão dobrada no fundo do objeto com a figura de Rosa. A observação perspicaz do advogado, atento às minúcias, remete o leitor à passagem em que Ananta abre uma gaveta e encontra o delineador que permaneceu intocado, o Cleopatra Exotic Eye Accents, na cor azul-turquesa, presente da atriz, que deveria ser usado para realçar os belos olhos azuis amendoados da analista, como realçava os olhos da própria Rosa.

O contraste entre a descrição física da analista e a de sua paciente e do apartamento de ambas dá a medida exata do comportamento e do caráter em franca oposição ${ }^{211}$ das personagens. A apresentação de Ananta revela-se como uma subversão radical dos conceitos estéticos que Rosa representa, no sentido de que reforçava uma imagem negativa de si

\footnotetext{
${ }^{210} \mathrm{O}$ argumento de Vera T. Silva a esse respeito caminha em uma direção um pouco diferenciada: "O distanciamento criado pela terceira pessoa é paralelo ao distanciamento que ela mesma se impõe: distante e impessoal, Ananta Medrado corporifica a eficiência, o profissionalismo." Nesse sentido, "ter voz narrativa implica expor-se, trair seu interior, e isso ela não faz." SILVA, Vera M.T. As Horas Nuas, um jogo de deciframento. In: A ficção intertextual de Lygia Fagundes Telles. Op.cit., p.71.

211 A visão de que Ananta seja o oposto de Rosa, assim como Rahul se constitua em espelho da protagonista, também é compartilhada por Almeida, que parte, no entanto, de pressupostos diferentes dos que utilizei neste trabalho. Cf. ALMEIDA, Sandra R.G. Castration and melancholia in Lygia Fagundes Telles' As Horas Nuas. Op.cit..
} 
mesma, quase sua descaracterização como mulher pela necessidade de demonstrar sua eficiência profissional com o 'apagamento' das marcas do feminino em seu corpo. Essa oposição delineia-se com contornos mais nítidos no posicionamento pessimista de Rosa sobre a emancipação da mulher e seu descaso com o movimento feminista e de mulheres dos anos 80. No romance, Ananta é representante do "feminismo profissionalizado das organizações não-governamentais", uma vertente oriunda da reorientação do próprio movimento diante da crise frente à ineficiência de organizações que apoiavam a mulher vítima de violência, culminando com a criação da Delegacia da Mulher, em $1985^{212}$. A atriz não só debocha da analista pelo serviço que prestava gratuitamente às mulheres na Delegacia da Mulher "quanto mais polêmica sutil mais olho roxo" (HN, p. 51) - como também tece críticas à educação sexual precoce, via televisão, defendida por Ananta.

A educação pelo rabo. Estimular os peitinhos liberados, os jeans tão colados que o fundilho se entranha na fenda e reparte o montículo lanhado ao meio, ai, ai, ai! ... E quando o macho vem e esgana e estupra fazem então aquele beicinho, Eu não queria e ele enfiou o pepinão em mim! (...) Algum sinal do hábito da escrita nos dedinhos? Nenhum sinal, zero. Fica anotado na ficha, Treze anos presumíveis. (...) Oferece o lenço de papel para a presumível vítima enxugar o olhinho vidrado de maconha, ah! meu Pai! Chega, estou exausta, não interessa. (HN, p. 21)

A atriz responsabiliza, desse modo, o apoio a comportamentos femininos mais liberais por toda sorte de desgraças que se abateram sobre a mulher. Faz-se necessário lembrar que o feminismo da década de 60 criticava o modo como as mulheres eram socializadas e submetidas às ideias de amor romântico, com seus papéis estereotipados, que conservavam as

\footnotetext{
${ }^{212}$ Nesse período, o movimento feminista foi marcado pela partidarização e pela luta por sua institucionalização, sem contar os inúmeros espaços conquistados pelas mulheres no campo político, por meio de Conselhos da Condição da Mulher e da presença feminina em cargos eletivos, além de formas alternativas de participação política. É importante destacar a participação ativa e atuante do movimento feminista e dos movimentos de mulheres durante os trabalhos preparatórios e no período de elaboração da nova constituição da Assembléia Nacional Constituinte, como a criação da "Carta das Mulheres", promovida pelo CNDM (Conselho Nacional dos Direitos da Mulher), que propunha a incorporação dos direitos da mulher na Constituição de 88. Ao lado de ações políticas e partidárias, surgiram muitas organizações que visam atuar com duas problemáticas em especial: a saúde e a violência contra a mulher. Em 1981, surge o SOS Mulher, que objetivava a criação de um espaço tanto para atendimento de mulheres que sofriam violência, quanto para reflexão das condições de vida dessas mulheres. As feministas atuantes em organizações como essas perceberam o hiato entre sua própria condição - a de mulheres que não sofriam esse tipo de violência e que, portanto, deixavam de ser sujeito de sua causa - e as mulheres agredidas, de precárias condições culturais e socioeconômicas, aquelas que não queriam tornar-se militantes feministas mas que desejavam apenas não serem agredidas novamente. A partir de então, os grupos passam a se organizar de maneira diferenciada, dando origem ao "feminismo de prestação de serviço, em que as mulheres vítimas da violência encontravam profissionais de saúde e da área jurídica para lhes dar apoio". In: PINTO, Céli Regina Jardim. Uma história do feminismo no Brasil. São Paulo: Editora Fundação Perseu Abramo, 2003, p. 81-82.
} 
posições tradicionais da mulher como ser dependente do homem ${ }^{213}$. Ao mesmo tempo, as feministas deslocaram a temática dominante do âmbito sentimental para colocaram em pauta a reivindicação pelo direito à autonomia sexual. Com o surgimento da pílula anticoncepcional, a sexualidade tornou-se maleável para as mulheres, sujeita a ser assumida de diversas maneiras e uma propriedade potencial do indivíduo. Ela passa a integrar uma progressiva diferenciação entre o sexo e as exigências da reprodução, tornando-a plenamente autônoma ${ }^{214}$. No entanto, apesar da distância da linguagem romântica e da aceitação cada vez menor de sacrificar a carreira em função do amor, o apego da mulher ao ideal amoroso, mesmo fora do casamento, perdurou ${ }^{215}$. Na militância feminista de Ananta, Lygia revela, pois, como o processo de desenvolvimento sexual e outras questões ligadas aos direitos da mulher passaram a se apresentar como um fenômeno de 'reflexividade institucional' ${ }^{216} \mathrm{em}$ constante movimento, retratados nos ciclos de debates dos quais a analista participava e que se tornaram parte de um domínio público mais amplo, na medida em que propiciaram a modificação das maneiras de pensar o amor, a sexualidade e os próprios direitos da mulher, como ser autônomo.

É possível entrever que, diferentemente de Ananta, que oferecia apoio às mulheres vítimas normalmente de seus companheiros agressores, Rosa prefere apostar na eficácia de reformas de base, a começar pela educação, para a solução de todo tipo de criminalidade, incluindo aí a agressão física à mulher. No diálogo entre Rosa e sua analista, a autora propositalmente não oferece respostas definidas às visões divergentes do feminino que ambas as personagens apresentam. Esse fato corrobora a intenção de trazer à tona, de colocar em discussão temas que se tornaram centrais no que tange à condição das mulheres brasileiras no período em que As Horas Nuas foi produzido e publicado. À queixa da atriz de que as mulheres encontram-se perdidas ${ }^{217}$, enlouquecendo ou se suicidando diante das transformações que alteraram profundamente suas relações com a carreira profissional, com a

\footnotetext{
${ }^{213}$ LIPOVETSKY, Gilles. A terceira mulher. Op.cit., p, 27.

${ }^{214}$ GIDDENS, Anthony. A transformação da intimidade. Op.cit., p. 39-40.

${ }^{215}$ LIPOVETSKY, Gilles. A terceira mulher. Op.cit., p.28.

${ }^{216}$ Ibid., p. 39.

${ }^{217}$ Em entrevista a Enio Squeff, Lygia declara: "Na divisão clássica das virtudes masculinas e femininas (...) há inversões que são o resultado de uma total deturpação da condição humana de ambos. É o exemplo da malícia feminina. Para se defender de uma situação de inferioridade, a mulher desfechou o contra-ataque da fragilidade, um dos vários ardis da tática da malícia. Mas isso só foi verdadeiro no plano físico. No plano intelectual, a situação é a mesma, o que não justifica qualquer disputa em termos de concorrência: jogar futebol para as mulheres é e continuará sendo ridículo em qualquer época”. In: SQUEFF, Enio. Timidez e afirmação da escritora brasileira. In: O Estado de S. Paulo. Op.cit., p. S. - 19.
} 
família e com a maternidade, Ananta responde que a "revolução é recente": "Pense num tubo de ensaio que foi sacudido, a água fica turva mas quando o depósito se assentar essa água vai ficar límpida. Ainda que o fundo seja de sangue.” (HN, p. 137)

Apesar das inúmeras diferenças que caracterizam as duas personagens, além da idade, a alusão a um vaso de flor que a analista ganhou de sua paciente Rosa Ambrósio sugere um elo entre ambas. Os crisântemos oferecidos por Rosa se constituem em um símbolo solar, associado às ideias de longevidade e de imortalidade, de plenitude e totalidade, da perfeição e da 'alegria para os olhos' ${ }^{\prime 218}$, que são justamente as máscaras envergadas pela atriz na construção de sua imagem pública. Levar um pouco dessa 'alegria' para sua analista revela, no entanto, uma outra acepção simbólica do crisântemo, que também é considerado uma flor outonal, estação do ano em que o romance tem início. Por essa razão, a flor é "aquela que, dentre todas as flores, se esconde e evita o mundo" ${ }^{219}$, assim como a própria Rosa e Ananta, em níveis diferentes, vivem no presente da narrativa. A atriz enclausura-se em seu apartamento quando chega à 'idade da madureza' por medo e dificuldade de aceitação de seu 'corpo em decadência', ao passo que Ananta, que possivelmente era virgem segundo Rosa, teme o amor. No entanto, a presença de flores em seu apartamento, pelo simbolismo que encerram, evidencia naquele ambiente límpido e insípido, o desejo carnal e o erotismo latentes, especialmente manifestado no vaso de orquídeas, com a intensidade e a violência trazidas pela cor amarela, solar, de suas pétalas.

Esse jogo de se expor e se mostrar também é a chave para a interpretação do desaparecimento repentino de Ananta ao final do romance. Numa noite, depois de comparecer a uma reunião feminista e de guardar o carro na garagem de seu prédio, Ananta nunca mais foi vista. Como as informações que a onisciência seletiva possui limitam-se à da personagem, que é o mesmo mecanismo encontrado no monólogo interior, o conhecimento de seu paradeiro não é revelado. A partir desse fato, instala-se na narrativa um mistério: para onde teria ido a jovem analista? Na ânsia de uma resposta para essa questão, uma amiga procura por um parente próximo na lista telefônica e encontra apenas um primo de segundo grau, Renato Medrado, que passa a investigar o possível paradeiro da analista. Entra em cena, outra vez, a onisciência seletiva, que a partir de então descreve as ações desse primo e aprofunda a análise mental da personagem com o recurso ao discurso indireto livre. As pistas que podem levar a uma resposta sobre o desaparecimento da analista estão espalhadas ao longo do texto,

\footnotetext{
${ }^{218}$ CHEVALIER, Jean; GHEERBRANT, Alain. Dicionário de símbolos. Op.cit., p. 302-303.

${ }^{219}$ Ibid., p. 303. Segundo os autores, a frase é atribuída ao filósofo Tche T'uen-yi.
} 
mas se tornam evidentes apenas com o surgimento de um misterioso vizinho, que passa a morar no apartamento acima do seu. Esse fato modifica o cotidiano de Ananta, pois ela sentese atraída pelo homem, possivelmente jovem, que todas as noites, no escuro, de acordo com a percepção da analista, metamorfoseia-se em cavalo e com quem ela estabelece comunicação através de batidas no chão, ao som da música clássica. Os compositores que lhe servem de ‘fio-guia' são Chopin, com Polonaises e Noturnos românticos, e Bach, com Prelúdio e Fuga, místicos e profundos.

Entrava no seu andar de homem ainda jovem mas prudente. Vigoroso mas cauteloso, não queria ser notado e por isso exagerava na discrição. No cuidado (não acendia as luzes) de pisar sem obstáculos e sem precipitação. $\mathrm{O}$ ritual dos gestos: tirava o chapéu, os sapatos. A capa impermeável era a peça mais difícil porque indócil, podia distinguir o ruído frio do tecido (preto) sendo dobrado. Amontoava tudo num canto. Deitava-se nesse chão sem tapete, exatamente no cômodo que correspondia à sala onde ela recebia seus pacientes. E entregava-se (também ele paciente) à metamorfose. Às vezes chegava mais tarde e seus movimentos pareciam mais vagarosos. Ou essa vagareza correspondia (por contradição) a um ritmo mais veloz? Imitando o recurso-clichê do cinema que recorre à câmara da lentidão quando quer exprimir velocidade.

O Vizinho entrava homem e virava um cavalo. (HN, p. 72-73)

Como representação simbólica da força e da potência criativa, o cavalo adquire uma valorização quer sexual quer espiritual, porque o animal participa simbolicamente tanto do plano ctoniano (lunar) como do uraniano (solar) ${ }^{220}$. A impetuosidade do desejo, da Juventude do homem, com tudo o que ela contém de ardor, de fecundidade, de generosidade atrai Ananta e lhe aguça os sentidos até então adormecidos e, por isso, desconhecidos. A metamorfose do corpo do homem que gradativamente estoura "em focinho, cascos, crinas" (HN, p. 79) desencadeia-se em noite de lua cheia e durante uma forte tempestade, que se amaina quando aquele processo de transformação chega ao fim. O quadro de Edward Hopper, Nighthawks (1942), que se encontra em seu apartamento, passa a ter significado intenso para ela durante uma noite em que ela espera pela chegada do Vizinho e seu processo de metamorfose. O termo nighthawk é usado em sentido figurado para descrever pessoas que permanecem acordadas até altas horas e retrata precisamente a situação vivida pela analista. No interior de um café quase vazio em uma esquina de Nova York encontram-se três clientes absortos em seus próprios pensamentos enquanto um funcionário parece lavar louças. Como tudo é visto do lado de fora do café, a rua completamente vazia e escura contrasta com a luz que incide sobre o estabelecimento através da extensa vitrine de vidro, enfatizando mais do

${ }^{220}$ CHEVALIER, Jean; GHEERBRANT, Alain. Dicionário de símbolos. Op.cit., p.209. 
que a solidão em uma grande metrópole, o próprio retrato da existência solitária do homem moderno. Do mesmo modo, Ananta parece adivinhar, no silêncio de seu escritório, a transformação desse homem em cavalo, separada dele apenas por uma barreira de concreto que se lhe afigura transparente tal como a vitrine do quadro de Hopper, um portal aberto pelo processo alquímico "que transformava a massa sólida em massa pastosa, beirando quase o estado gasoso" (HN, p. 86) e permite-lhe reconhecer o medo e a solidão de que o Vizinho e ela própria eram tomados. Na mesma linha em que Rahul e Rosa questionam os limites entre fato e imaginação, Ananta também põe em dúvida a natureza de sua descoberta: "as alucinações auditivas (mais fortes do que as visuais) não seriam simples consequências dessa misteriosa febre-interna que nem o termômetro (quebrado) podia medir?” (HN, p. 87). Ou ainda: “(...) E se os calafrios na noite quente não passassem de agravantes da enxaqueca” (HN, p. 88). Seu médico a tranquilizara com a declaração de que os exames realizados devido às constantes enxaquecas revelaram que não havia nada de errado com aquela "bela cabeça", afastando as hipóteses de Ananta, levantadas em segredo, de que tais sensações fossem sinais de doença ou loucura. O uso do adjetivo "bela" feito pelo médico e repetido por Ananta em um momento de reflexão prenuncia a metamorfose que estava prestes a ocorrer com a analista, no olhar para o próprio corpo e na manifestação da sensualidade, quando ela passa as mãos pelos cabelos, pelos botões do avental e vai à cozinha buscar mel, alimento símbolo de morte e de vida, com forte conotação erótica, que evoca para a analista o “ (...) despertar primaveril iniciático" ${ }^{221}$. Esse sentido é completado pelo ato de se inclinar por sobre os potes de orquídea para sentir-lhes o "perfume roxo-úmido", associação sinestésica que dá os últimos contornos dessa abertura da analista para os mistérios do amor, do prazer e do sexo, signo da nova vida para a qual se sentia despertada.

É sintomático também que aquele embate de ideias entre a analista e sua paciente tenha ocorrido durante a última sessão de Rosa antes do desaparecimento de Ananta, quando a atriz questiona a postura favorável das feministas acerca do aborto e tece comentários sobre questões ligadas ao comportamento masculinizado das mulheres, as quais estariam se igualando aos homens pelo desejo de poder. $\mathrm{Na}$ mesma sessão, Rosa faz uma crítica à profissão de Ananta, confirmando sua imagem como mulher saturada pela rotina de atender os 'chatos' pacientes e enfrentar os conflitos do 'mulherio' em seu trabalho voluntário. Esses comentários reforçam o fato de que, depois do aparecimento do Vizinho, a jovem analista começava dar mostras de que seu trabalho já não a satisfazia plenamente; o telefone começa a

${ }^{221}$ CHEVALIER, Jean; GHEERBRANT, Alain. Dicionário de símbolos. Op.cit., p. 604. 
ser comparado à figura de um "besouro enterrado vivo" e à de um ferro em brasa, demonstrando que Ananta atendia aos chamados de seus pacientes problemáticos, que beiravam à loucura, com certa impaciência. $\mathrm{O}$ comentário da atriz de que a analista acabaria sem vida própria naquela concha em que seu escritório se transformara corrobora a constatação de Ananta, capítulos antes, quando planejava ir à Delegacia da Mulher, de que pouco podia fazer por essa mulher. Como lembra Bachelard,

o ser que se esconde, o ser que 'entra em sua concha' prepara uma saída. (...) parece que, ao conservar-se na imobilidade de sua concha, o ser prepara explosões temporais do ser, turbilhões do ser. As mais dinâmicas evasões ocorrem a partir do ser comprimido, e não na preguiça frouxa do ser preguiçoso que só deseja espreguiçar-se em outro lugar. ${ }^{222}$

Com o desaparecimento da analista, As Horas Nuas engenhosamente parecem enveredar pelas trilhas do romance policial. Silviano Santiago, na resenha publicada em 1989 sobre As Horas Nuas, afirma que o romance, que tinha tudo para ser ótimo, acaba sendo apenas bom. Ele afirma que Lygia peca por introduzir, além das reminiscências do amor juvenil de Rosa e seu primo Miguel $^{223}$, uma personagem "pouco convincente", "mal trabalhada pela romancista e que beira o pior clichê":

A possível demência de Ananta e sobretudo seu desaparecimento misterioso no final do romance (quando já é então personagem de primeiríssimo plano) dão um toque de 'policial' à narrativa. Surge um terceiro narrador no romance. Uma terceira pessoa convencional, retirada de qualquer romance de detetive. Nova conjetura. Por que o bom romancista brasileiro atual se encontra tão seduzido pelas formas do romance policial? Acredita ele que será mais compreendido do seu possível público? Acredita ele que, num determinado momento em que a leitura se torna necessariamente cansativa e mais exigente, o recurso ao policial pode aliviar as penas do leitor? ${ }^{224}$

A transposição para o contexto brasileiro desse tipo de narrativa, que se transforma em nicho de mercado com o domínio da televisão e do rádio ${ }^{225}$, ganha definitivo terreno somente na década de 80, com a publicação de A grande arte, de Rubem Fonseca quando o país

\footnotetext{
${ }^{222}$ BACHELARD, Gaston. A poética do espaço. Op.cit., p.123.

${ }^{223}$ Este aspecto será desenvolvido no capítulo "Memórias Deslumbrantes".

${ }^{224}$ SANTIAGO, Silviano. Romance traz o tango das ilusões perdidas. Op.cit., p. G-6.

${ }^{225}$ Sobre as condições que contribuíram para a sustentação do romance policial no Brasil a partir da segunda metade do século XX, consultar Antonio CANDIDO. Literatura e subdesenvolvimento. In: A educação pela noite e outros ensaios.São Paulo, Ática, 2000 e PELLEGRINI, Tânia. A imagem e a letra - aspectos da ficção brasileira contemporânea. Campinas: Mercado de Letras/ São Paulo: FAPESP, 1999.
} 
apresenta as condições necessárias para o desenvolvimento efetivo de uma cultura de massa. A clássica narrativa policial supre necessidades subjetivas do leitor, tais como "a estranha e atávica atração humana pelo mistério, pela violência e pela sordidez”, até “o gosto pelo espírito dedutivo necessário para o deslinde das tramas, passando pelo gosto da aventura e do drama na monotonia das pessoas" ${ }^{\text {"226 }}$.No caso de As Horas Nuas, no entanto, não há um sujeito detentor da verdade, com uma visão neutra e objetiva dos fatos, que, com base em pistas deixadas pelo 'criminoso', consegue pôr fim ao crime que se apresenta ao detetive, como na tradicional narrativa policial. As opiniões de vizinhos, pacientes e de colegas feministas sobre Ananta eram muito semelhantes e pouco colaboraram para que a investigação chegasse a bom termo: a analista de trinta e um anos, solteira e médica era uma moça inteligente, delicada mas firme, corajosa; a empregada Marlene notara que, no dia em desaparecera, a patroa estava um pouco mais feliz do que de costume. Já Rosa Ambrósio acreditava que sua analista tinha fugido para viver e o próprio Renato cogitava a possibilidade de um amor secreto cultivado pela prima amedrontada e tonta da infância, como o sobrenome Medrado sugere. Na falta de evidências capazes de garantir essa constatação, o advogado chega ao impasse da falta de solução e permanece na zona da ambiguidade.

Onde Santiago vê, pois, um grave defeito, outro crítico, José Paulo Paes, percebe justamente o "tour de force" da escritora neste romance, o qual

(...) me parece estar no ardiloso desvio do centro de interesse da narrativa na sua parte final. Quando se esperava que então (...) o centro do palco fosse ser ocupado pela protagonista, eis que ali avulta uma personagem secundária, Ananta Medrado, a psicanalista de Rosa. (...) É como se a romancista quisesse passar ao leitor o encargo de inventar, por conta própria, alguma explicação do inexplicável sumiço. Mas, para ajudá-lo nisso, cuidou de semear antes algumas pistas significativas ao longo da narrativa. ${ }^{27}$

Paes observa em As Horas Nuas uma característica que também é marcante na produção literária de Lygia: a de passar a responsabilidade ao leitor de preencher as lacunas que estão espalhadas em torno do desaparecimento de Ananta, em parceria com a escritora, cujo objetivo é integrá-lo na atividade de completar os sentidos em aberto de sua obra. Apesar do clima de mistério e das inúmeras motivações aventadas pelo delegado que levariam uma pessoa a desaparecer, as pistas seguidas por Renato não o levam a qualquer conclusão sobre o

\footnotetext{
${ }^{226}$ PELLEGRINI, Tânia. A imagem e a letra - aspectos da ficção brasileira contemporânea. Op.cit., p. 81.

${ }^{227}$ PAES, José Paulo. Entre a nudez e o mito. In: Transleituras. São Paulo, Companhia das Letras: 1995, p.43.
} 
desaparecimento da prima amedrontada que conhecera na infância; não há, portanto, resolução do mistério, não há uma única verdade, central, que o sustente como tal, como na clássica narrativa policial. Contrariamente à visão de Santiago de que a saída pelo romance policial é uma maneira de tornar a leitura menos desgastante ao leitor, é possível observar que essa saída pelo tom detetivesco da narrativa policial, em que a personagem Renato Medrado reflete sobre a falta de indícios concretos que possam explicar o desaparecimento da prima, torna a leitura dos capítulos mais cansativa. Isso se dá principalmente pela arrogância e pelo pedantismo do advogado com relação às mulheres, à própria inteligência e ao suposto talento para escritor e detetive, que se revelam ignóbeis. No sentido aqui exposto, o toque 'policial' no final do romance descortina a posição adotada por Rosa e Ananta, mas também por Rahul, como personagens em busca de uma resposta que possa pôr fim ao seu 'moinho interior', como sugere a analista, o que as aproxima da figura de investigadoras de si mesmas:

Que palavra secreta ela teria dito para fazer silenciar o seu moinho interior? Não sabia. Sabia apenas que em certas noites se sentia tão insegura quanto ele. E ainda assim, tinha forças para animá-lo solidária, transmitindo através da invenção do código (coração-mente) a linguagem do amor. (HN, p. 87)

A palavra secreta fora, na verdade, a expressão "eu te amo", repetida em meio à explosão do choro de conotação orgástica da analista após ouvir as batidas no assoalho do apartamento de seu Vizinho, como resposta ao código inventado, ao mecanismo de comunicação com esse homem, que consistia em bater com os punhos cerrados no chão: tumtum, o ritmo das batidas do coração. No episódio já mencionado no capítulo anterior, em que Ananta encontrara Cordélia na saída do prédio onde moravam, além de uma certa crítica inerente ao seu comentário àquela vida 'alegre e transitória e vã”, se comparada às atividades desenvolvidas pela analista, Ananta também manifesta um agradecimento por ter descoberto naquele instante que a verdadeira luz "ficara com a moça do dragão tatuado", isto é, que acima de tudo, o mais importante era "cumprir sua vocação", mesmo que fosse para viver a vida como se estivesse no mundo a passeio, como Cordélia. O encontro com a filha de Rosa desencadeia sua posterior compreensão de que também ela, Ananta, deveria "ouvir o chamado". Havia chegado o momento, portanto, de "cravar os dentes na maçã", de "acertar o alvo", de "ousar a alegria proibida" - de conhecer o amor.

Os inúmeros vestígios espalhados ao longo de As Horas Nuas indicam que Ananta, sob a máscara de um equilíbrio entre consciente e inconsciente, entre essência e aparência, esconde-se em um lugar onde ninguém imagina encontrá-la. A personagem afirmara que o 
Vizinho e ela tinham medo da "crueldade acesa" do mundo: "Se ao menos pudesse escondê-lo num lugar defendido. Seguro. A antiga fazenda dos tios seria o melhor esconderijo, tudo dentro da natureza ficava natural, até ele. Antes e depois, principalmente depois" (HN, p. 89). A pista concreta deixada ao leitor sobre seu desaparecimento, no entanto, encontra-se na imagem estampada na tapeçaria encontrada em seu apartamento, a qual pertencera aos avós de Renato também. A referência que Ananta faz, no diário, à necessidade de caminhar por longas horas e abraçar as árvores, quando sente a necessidade de estar em contato com suas “reservas florestais' e sentir na pele o “áspero das gretas” (HN, p. 75) é uma espécie de projeção em sua vida pessoal da figura retratada na tapeçaria:

[Renato] Ajustou os óculos que escorregavam do nariz para examinar de perto a tapeçaria que ocupava o centro da parede. Então era esse o terrível bosque verde-negro com a sombra de um castelo tão remoto lá no fundo que era mais para ser adivinhado do que vislumbrado. Isto estava na casa dos meus avós. Eu era menino quando vi essa tapeçaria. Não tenho idéia como veio parar com Ananta, outro mistério. (HN, p. 244)

A sombra do castelo adivinhado através do bosque verde-negro corresponde àquela descrição que Ananta faz do apartamento do Vizinho, também supostamente desvendado através da opacidade do teto-portal do sexto andar, onde mora a analista. O castelo, seja na vida real ou nos contos de fada, está normalmente situado em locais de difícil acesso como os lugares altos ou a clareira de alguma floresta e, por isso, transmite a sensação de segurança ${ }^{228}$, o que sugere também a correspondência simbólica que essa figura estabelece com o apartamento do Vizinho de Ananta, o último, o da cobertura, cheio de goteiras. Por outro lado, devido à sua localização isolada com relação ao resto do mundo, o castelo "adquire um aspecto longínquo, tão inacessível quanto desejável"229, que representa justamente o sentimento ambíguo da analista frente à atração provocada por aquele lugar. Desse modo, o apartamento do Vizinho tem as mesmas acepções simbólicas do castelo: torna-se, para Ananta, o símbolo da proteção, mas também o da transcendência, da conjunção dos desejos. O terror provocado pelo bosque que cerca o castelo da tapeçaria corresponde ao mesmo sentimento manifestado pela personagem quando escreve em seu diário, por duas vezes em sequência, a palavra "pavor", como expressão do medo de que seu desejo latente estivesse

\footnotetext{
${ }^{228}$ CHEVALIER, Jean; GHEERBRANT, Alain. Dicionário de símbolos. Op.cit., p. 199.

${ }^{229}$ Ibid., p. 199.
} 
prestes a ser revelado, já que a imagem do castelo às escuras também simboliza o inconsciente e a memória confusa. ${ }^{230}$

É possível identificar que Renato, acostumado à busca racional de uma verdade unificadora e única e que prefere o cinema ao teatro, porque, como um homem "ligado em minúcias", neste "tudo fica perto demais", ao passo que naquele, "a realidade se distancia, fica menos real” (HN, p. 232), contraditoriamente não apresenta a astúcia suficiente para perceber que a solução para o mistério está sugerida na tapeçaria. Por isso, o esforço de fazer As Horas Nuas enveredar pelas trilhas desse tipo de narrativa no final do romance sugere uma visão paródica da personagem Renato Medrado, expressa na racionalidade masculina que supõe saber sobre tudo, especialmente sobre as mulheres.

O mistério do feminino, sua dimensão eterna de incerteza e de imprevisibilidade se recompõe, então, mesmo através da abertura e da multiplicação de seus papéis. Qualquer que seja a força da cultura da igualdade e da autenticidade, a mulher continua a ser inapreensível, enigma cuja sedução permanece inalterável. ${ }^{231}$

Lipovetsky fala de um ponto de vista estritamente masculino, já que sua argumentação reitera a propalada imagem da mulher como eterno enigma indecifrável. Contudo, pela leitura atenta do romance, o comentário do autor francês torna perceptível, no discurso que subjaz na reflexão de Renato Medrado, que a mulher, antes de permanecer na esfera do intangível e do sedutor, continua sendo seu próprio enigma, com a necessidade de descoberta de outras potencialidades e direitos por si própria.

Todo processo é lento, diz a pequena Ananta. Mas com o tempo as coisas vão se ajustando. A fase inicial de agressividade já passou, as mulheres agora estão evoluindo para um entendimento mais profundo no trabalho. No amor, prossegue ela tomando seu chá de jasmim. (HN, p. 21)

Assim como Rosa, a 'terceira mulher' Ananta apresenta sua persona privada como diversa de sua persona pública, mas a superficialidade, o distanciamento e o comportamento regrado cedem espaço à busca do desejo, do prazer, do amor em suas raízes mais profundas. Diante da ineficácia da investigação, Renato Medrado delineia o comportamento da prima organizada "como a própria alcachofra com o coração esquivo escondido no círculo fechado

\footnotetext{
${ }^{230}$ CHEVALIER, Jean; GHEERBRANT, Alain. Dicionário de símbolos. Op.cit., p. 199.

${ }^{231}$ LIPOVETSKY, Gilles. A terceira mulher. Op.cit., p. 67.
} 
das sentinelas das folhas” (HN, p. 228). Essa ideia de algo guardado lá no fundo, expressa em metáforas como esta, revela que o 'que interessa' está escondido e perpassa o romance como um todo, no tocante à questão da mediação e ao jogo da representação em As Horas Nuas. A mesma tensão vivida pela personagem entre se esconder e se mostrar também é observada nos capítulos do romance que tratam de seu desaparecimento, oscilando entre a revelação trazida por uma pista e outra através do discurso indireto livre, já que a onisciência seletiva, como tal, opta por ver os fatos pela ótica de Ananta. Diferentemente de Rosa, a analista temia que suas características femininas fossem descobertas na persona pública que envergava. A mudança em seu modo de pensar e de agir corresponde à própria abertura dentro do movimento feminista para temas anteriormente relegados a um segundo plano, como as questões ligadas ao universo cultural feminino até então recusado em favor da participação pública e política da mulher, e que passa a ser incorporado de maneira renovada na esfera pública, forçando um alargamento e uma democratização desse espaço ${ }^{232}$. Acima de tudo, essa nova forma de comportamento corrobora a constatação de que "o feminino se constrói, de agora em diante, na conjunção dos desejos de controle do destino individual e dos desejos de entrega emocional interpretados como estrada real rumo a uma vida rica e plena." ${ }^{233}$

Ao entrar no apartamento de Ananta pela última vez para encerrar a investigação, no capítulo final do romance, Renato tem a impressão de que se tratava de um lugar habitado e desabitado, sentimento reforçado pelo perfume vigoroso das orquídeas amarelas. Essa flor, símbolo da fecundação, de perfeição e de pureza espirituais ${ }^{234}$, é associada às festas da primavera, estação do ano em que as personagens se encontram ao final do romance, fechando o ciclo sazonal que se iniciara no outono. Assim como o caracol sai de sua concha após o longo inverno, o provável renascimento de Ananta, assim como a pretensa 'ressurreição' de Rosa, vem prefigurado, portanto, na estação das flores. O canteiro de Amores-Perfeitos na parte externa do prédio onde moram as personagens, anteriormente ignorado pelo advogado, completa esse cenário:

Renato Medrado agachou-se. Surpreendente, murmurou e sorriu para as máscaras amarelo-roxas das florinhas que pareciam encará-lo com a mesma curiosidade, pingando água. Mas não era mesmo incrível? Não ter visto o

\footnotetext{
${ }^{232}$ RAGO, Margareth. Os feminismos no Brasil: dos "anos de chumbo" à era global. Labrys- estudos feministas, n.3, jan.-jul. 2003. Disponível em: $<$ http://vsites.unb.br/ih/his/gefem/labrys3/web/bras/marga1.htm> Acesso em: 21 dez. 2009.

${ }^{233}$ LIPOVETSKY, Gilles. A terceira mulher. Op.cit., p. 32-33.

${ }^{234}$ CHEVALIER, Jean; GHEERBRANT, Alain. Dicionário de símbolos. Op.cit., p. 664.
} 
canteiro das pequenas mascaradas que sempre estiveram ali. $\mathrm{O}$ que mais teria deixado escapar? (HN, p. 246)

O Amor-Perfeito, com suas cinco pétalas, evoca a meditação e a reflexão porque "designa o homem pelo que lhe é próprio: pensar" 235 . No entanto, as cores contrastantes de suas pétalas aludem à representação de pequenas máscaras sobrepostas, metáfora da impossibilidade de dissecar a condição humana, o pensamento mais recôndito guardado em cada ser, as motivações que levam cada um a realizar suas escolhas, como o romance preconiza. Quando Renato acredita ter conversado com 'todos' e dá a investigação por encerrada, Dionísia jocosamente declara que faltara entrevistar Rahul, o felino que "até que fala demais às vezes" (HN, p.245). Por essa razão, a imagem do canteiro contrasta com a presença do gato atrás da vidraça do apartamento de Rosa, sugerindo ao leitor que ele conhece o paradeiro da analista, o fio da investigação que Renato deixara escapar.

Pela transformação que simbolicamente proporciona, dado o poder mágico que encerra, o sete é o número do andar em que ficava o apartamento do Vizinho que, pelo desconhecimento do nome e de outras informações, recebe essa denominação, como substantivo próprio. O sete, que também está associado à ansiedade, é revelador, portanto, do sentimento da analista enquanto aguarda a chegada desse homem à noite, juntamente com as tempestades, pois o simbolismo do referido número está associado à passagem do conhecido ao desconhecido ${ }^{236}$. Na ambiguidade reforçada pelo desaparecimento da prima de comportamento exemplar, é possível apreender que o mistério concentra-se justamente naquela tapeçaria, possível metáfora da fazenda dos tios de Ananta, para onde ela poderia ter ido viver com o Vizinho. O prédio onde a atriz e a analista moram é constituído de um apartamento por andar e a posição que ocupam nesse lugar é sugestiva da nova condição de ambas as personagens no que se refere ao relacionamento amoroso. O número quatro, que corresponde ao andar onde a atriz reside, simboliza a terra, cujos atributos caracterizam seu comportamento com relação a Diogo; este, inicialmente, ocupava o apartamento do terceiro andar, número associado ao céu, que, por sua vez, está ligado à caracterização do gigolô. Como Diogo fora expulso por Rosa e provavelmente não voltará, a atriz não se realiza no amor mais uma vez. No entanto, esses números, somados, resultam no número sete ${ }^{237}$, o qual

\footnotetext{
${ }^{235}$ CHEVALIER, Jean; GHEERBRANT, Alain. Dicionário de símbolos. Op.cit., p.48.

${ }^{236}$ Ibid., p.828.

${ }^{237}$ Ibid., p. 826.
} 
"representa a totalidade do universo em movimento", a plenitude alcançada pela analista como "a do homem perfeito, perfeitamente realizado.",238

Ananta configura-se, portanto, em um espelho para a protagonista, na medida em que representa sua imagem invertida, corroborada pelo ponto de vista escolhido pela autora, que mantém a perspectiva distanciada da onisciência seletiva que assume a consciência da analista. O monólogo interior da protagonista, que perpassa o romance, favorece a quebra das antigas imagens de si e o seu sugerido renascimento ao final. Já velha, Rosa luta por uma auto-integração que visa a sua reintegração social - a publicação de suas memórias, o retorno do amante e a volta ao palco, ao centro das atenções e olhares do público e da mídia. Por outro lado, a analista, integrada que está à esfera social do trabalho e da participação ativa em prol da mulher, percebe que continuar sua luta feminista engajada e sua rotina de atender os pacientes sem dar vazão aos seus desejos inconscientes e à sua sexualidade, aguçados pelo Vizinho do sétimo andar, pode resultar no isolamento de si mesma, na infelicidade completa; quando sai em busca do lado obscuro, da paixão por tanto tempo evitada, é que a personagem encontra a resposta para seu moinho interior. Seduzida pela figura simbólica do cavalo, passa por um processo de renascimento num sentido oposto ao de Rosa e, por isso, constitui-se no oposto de sua imagem: é em sua desintegração social que ela possivelmente alcançará a tão desejada auto-integração. Diferentemente de sua paciente, a jovem analista não se 'reconstitui' de acordo com as normas e os papéis sociais diferenciados ${ }^{239}$; seduzida pelo Vizinho, ela também passa por um processo de metamorfose, assumindo seu lado felino, sua sexualidade, voltando-se mais para o espaço da vida privada, de seu mundo feminino. Se na figura de Rosa a 'dependência amorosa' revela-se como uma espécie de 'servidão', na personagem de Ananta o amor é justamente o libertador, que descortina outras dimensões de ser mulher.

\section{2. "Sair da vida ao nível do chão"}

Atores e gatos apresentam uma semelhança notória. Os primeiros, pelo ato de representar, encenam outros seres, que não o próprio eu, no palco; os segundos, de acordo com a crença popular, podem viver até sete vidas. O trabalho de interpretação do script se

\footnotetext{
${ }^{238}$ CHEVALIER, Jean; GHEERBRANT, Alain. Dicionário de símbolos. Op.cit., p. 831.

${ }^{239}$ LIPOVETSKY, Gilles. A terceira mulher. Op.cit., p. 239.
} 
completa, no caso do ator, com o processo de caracterização, em que se utiliza da maquiagem, do figurino e do movimento para representar uma personagem, o que pode torná-lo verossímil ao público; pode 'vivenciar' outras vidas em seu corpo transformado em outros corpos, segundo a necessidade de cada representação. O gato, por sua vez, poderia, numa viagem pelo tempo e pelo espaço, transmigrar sua alma em outros corpos, assumindo, assim, novas existências.

A presença de um gato, "sem raça, castrado e com memória" no romance As Horas Nuas é, sem dúvida, um dos aspectos mais inovadores da obra ficcional de Lygia Fagundes Telles. O cerne dessa personagem pode ser encontrado em um fragmento do livro A disciplina do amor, no qual Lygia refere-se à figura do gato como um "fragmento do Paraíso", um animal com "um certo ar de latinista, que vai até a raiz das coisas" e que "gosta de poesia" "rios de poetas foram se inspirar em gatos com suas emanações de sortilégio. Magia" 240 , assim como a própria escritora parece ter se inspirado para a criação de Rahul. No limite entre memória e invenção, esse gato agarra-se aos vestígios e "poeiras de suas lembranças": ele vivera como poeta na Roma Antiga; fora atleta e, depois, um menino de cachos na casa das venezianas verdes, a mais longa e detalhada das lembranças; em outra época, morrera muito jovem no leito de um hospital por overdose de heroína. Nesta vida, Rahul 'reencarnara' na pele de um gato encontrado pela atriz na saída de um teatro e, assim como Rosa, está velho. Ao invés de telhados e muros, é pelo restrito espaço do apartamento da atriz que ele circula; nesse gato, os vícios humanos dos quais está impregnado convivem com "o apetite do bicho" (HN, p.105), marcando sua dupla condição: corpo de animal e alma humana.

Da longa convivência com o rodapé, o gato aprendeu a identificar "os donos dos sapatos antes mesmo de encará-los ou de ouvir suas vozes” (HN, p. 32). Por isso, nos traços dos calçados, o felino, cuja condição de animal permite-lhe certa mobilidade dentro do apartamento que habita e percorre, dá a dimensão exata de quem por ele circula: os sapatos italianos, impecáveis, de Diogo, revelam a vaidosa figura do gigolô; os sapatos desgastados de Gregório guardam o formato de sua pisada 'para fora', o "andar do sonhador"; as alpargatas brancas e fosforescentes de Dionísia evocam a sua vida regrada; as dúzias de sapatos intocados de Rosona revelam a dispersão da mulher-nuvem que deseja para em seguida esquecer, motivada por outro desejo; a ausência de sapatos nos pés bonitos de Cordélia, que circulam descalços pelas escadas do prédio. Como felino, habita e percorre todos os cômodos do apartamento; sua aparência animal permite-lhe certa liberdade dentro

\footnotetext{
${ }^{240}$ TELLES, Lygia. F. A disciplina do amor: fragmentos. Rio de Janeiro: Rocco,1998, p.16.
} 
desse limitado território, onde sua presença, muitas vezes, é despercebida: é o gato, como vimos, quem revela como eram as brigas entre Rosa e Diogo; quem teimosamente assistiu às etapas do suicídio de Gregório; é ele também, como vimos, que testemunha a intimidade de Rosona, o trabalho de Dionísia e é o único ser que surge na janela do apartamento de Rosa ao final do romance, certamente conhecendo o rumo tomado pela analista, ignorado pelas demais personagens. De modo surpreendente, esse gato apresenta-se, já no segundo capítulo do romance, com a função de narrador- testemunha e de personagem, o que provoca no leitor o questionamento sobre o significado de sua existência com relação à protagonista que se apresentara no capítulo anterior através de um monólogo delirante e caótico: que terreno movediço é este sobre o qual essas personagens se movem?

O leitor, acostumado com elementos que oscilam entre o fantástico, o estranho e o maravilhoso/ alegórico nos contos de Lygia, como "As formigas", "Lua crescente em Amsterdã”, “A caçada”, “O Anão de Jardim”, "Seminário dos ratos”, “Tigrela”, "Emanuel”, "WM", por exemplo, é apanhado de surpresa com a inserção de um animal com alma humana em seu último romance. Alguns críticos como José Paulo Paes ${ }^{241}$ e Cristina Ferreira-Pinto ${ }^{242}$ aceitam Rahul e Ananta como duas dimensões do fantástico inseridas em As Horas Nuas, mas do ponto de vista adotado nesta tese, essa perspectiva pode limitar o alcance que uma personagem como Rahul adquire no romance. Se recorrermos à teoria do fantástico na literatura, como a proposta elaborada por Tzvetan Todorov, por exemplo, será possível delinear com mais clareza que a figura do gato, no entanto, foge a qualquer esquema que o reduza à condição de elemento fantástico. O autor aposta na tensão entre o mundo real, com suas leis naturais, e o mundo imaginário, com explicações sobrenaturais diante de algum acontecimento que não pode ser explicado por aquelas mesmas leis para defender sua teoria; para ele, a hesitação entre a 'fé absoluta' e a 'incredulidade total' daria vida ao fantástico ${ }^{243}$. Todorov foi criticado por inúmeros teóricos justamente por colocar um forte peso na função do leitor implícito, naquilo que ele considera as três condições que necessariamente devem ser preenchidas para que sua definição de fantástico se realize em plenitude. Primeiramente, o texto deve obrigar o leitor a hesitar entre uma explicação natural e uma sobrenatural dos acontecimentos; tal característica remeteria ao aspecto verbal do texto - o fantástico seria um

\footnotetext{
${ }^{241}$ PAES, José Paulo. Entre a nudez e o mito. In: Transleituras. Op.cit., p.42.

242 PINTO, Cristina F. Consciência feminista/Identidade feminina: relações entre mulheres na obra de Lygia Fagundes Telles. In: SHARPE, Peggy (org.). Entre resistir e identificar-se: para uma teoria da prática narrativa brasileira de autoria feminina. Op.cit., p. 74.

${ }^{243}$ TODOROV, T. Introdução à literatura fantástica. São Paulo: Perspectiva, 2003, p. 36.
} 
caso particular de visão ambígua. A segunda condição diz respeito a tal hesitação poder ser experimentada por uma personagem e, assim, tornar-se representada no texto, isto é, tema da obra, e estaria de acordo tanto com o aspecto sintático da obra, o que implica as reações às ações contidas na trama, quanto com o aspecto semântico, por se tratar justamente da representação de um tema. E a terceira condição refere-se à postura adotada pelo leitor, que o faz recusar tanto a interpretação alegórica quanto a interpretação poética, já que se trata de uma opção entre vários modos e níveis de leitura. ${ }^{244}$

Aparentemente, a primeira condição desenvolvida pelo teórico russo poderia ser considerada para explicar o surgimento do gato devido à maneira como essa personagem se apresenta logo após a recordação de sua existência anterior em tempos remotos: “Apertei meu peito inquieto com a palma da mão assim como faço agora. A diferença é que já não tenho mão à altura do gesto, mas uma pata. Veludosa. As unhas bem aparadas para não puxar o fio dos tapetes de Rosa Ambrósio" (HN, p. 27). De acordo com Paes, o ponto em comum entre os teóricos do fantástico consiste na afirmação de que este “(...) se opõe diametralmente ao real e ao normal”245. O dinamismo dos acontecimentos que envolvem Rahul não modificam, no entanto, o cotidiano das demais personagens porque aqueles fatos ocorreram em outros tempos e encontram-se encerrados no domínio da memória da personagem, que no presente da narrativa vive simplesmente como qualquer felino: faz sua toalete, "dorme-acordado" sobre as almofadas, anda pela cama da protagonista, pelas escadas atapetadas do prédio, sobe na pia da cozinha, entra no escritório de Gregório, observa a lua pela janela. Segundo Antonio Cândido, num romance, "um traço irreal pode tornar-se verossímil, conforme a ordenação da matéria e os valores que a norteiam, sobretudo o sistema de convenções adotado pelo escritor”246. Em As Horas Nuas, a autora opta por um diálogo com o romanesco através de Rosa, como vimos no capítulo 3, e de Rahul, partindo de um elemento comum e que também se constitui no traço essencial dessa categoria narrativa: o tema da procura, a busca de uma realização que os torne livre das angústias da realidade, mas que integre essa realidade. ${ }^{247}$

A presença do gato no romance evoca as histórias romanescas, tanto no que concerne às narrativas maravilhosas, em que as aventuras das personagens acontecem em um mundo

\footnotetext{
${ }^{244}$ TODOROV, T. Introdução à literatura fantástica. Op.cit., p. 38-39.

${ }^{245}$ PAES, José Paulo. As dimensões do fantástico. In: Gregos e Baianos. São Paulo: Brasiliense, 1985, p. 184.

${ }^{246}$ Antonio CANDIDO. A personagem no romance. In: CANDIDO et alii. A personagem de fiç̧ão. Op.cit., p. 77.

${ }^{247}$ FRYE, Northrop. Anatomia da crítica. Op.cit., p. 191.
} 
mágico, onde os fenômenos não obedecem às leis naturais que regem os seres humanos ${ }^{248}$, quanto ao mundo alegórico/simbólico das fábulas, as pequenas histórias de caráter moralizante que apresentam como personagens animais irracionais dotados do atributo da fala e de comportamento semelhante ao dos humanos. Essas características são reforçadas pelo fato de o gato lembrar-se de que, no tempo em que era um 'menino de cachos', viu sobre o piano de sua casa um livro de fecho de prata em cuja capa havia a gravura do Gato de Botas, com sua roupa de veludo cotelê verde, com um chapéu de feltro e pluma vermelha, e um cinto de couro: "Histórias do tempo em que os animais falavam, eu falei pouco" (HN, p. 28) ${ }^{249}$. Por ser considerado um ente metade benéfico, metade maléfico, símbolo da sagacidade e da engenhosidade, Rahul, como os gatos fantásticos/ maravilhosos -Murr ou o de Cheshire -, não assume um compromisso ético-moralizante na narrativa de As Horas Nuas, mas seu fluxo de consciência dá justamente a medida das implicações ideológicas que subjazem nas recordações da vida em outros tempos e na esperança de voltar como ser humano em uma próxima existência. Ao dotar um animal com características essencialmente humanas como o pensamento crítico e a capacidade de reconstruir fatos perdidos na memória, a escritora encontrou uma maneira inusitada para percorrer o 'outro lado', o invisível ou o oculto nas personagens, para tentar despir as máscaras que as recobrem e desnudar/desconstruir a realidade que elas julgam ser 'real', incluindo aí a do próprio felino. Não é à toa que o bicho escolhido tenha sido um gato: o simbolismo que o envolve vincula-o à representação de animal do limiar, o qual mantém laços com o 'outro lado', porque teria o dom da clarividência; como mágicos, teriam a possibilidade de penetrar com livre trânsito entre o

248 COELHO, Nelly N. Literatura Infantil - teoria, análise, didática. São Paulo: Ática, 1997, p.153. É interessante atentar para a distinção que a autora faz entre o conto maravilhoso e o conto de fadas. No primeiro, as ações decorrem no mundo da magia, da fantasia ou do sonho, em que tudo se resolve por meios sobrenaturais; a natureza das aventuras é sempre de ordem material/social/sensorial. Já os contos de fada são de natureza espiritual/ética/existencial e apresentam a figura da Fada como mediadora mágica e "heróis ou heroínas ligadas ao sobrenatural, ao Mistério do além-vida e visavam a realização interior do ser humano" (p. 154-155). As aventuras de Rahul, enquanto gente, eram da mesma natureza dos contos maravilhosos; na pele de um gato, o sentido de suas recordações passam a ser da natureza dos contos de fada.

${ }^{249} \mathrm{Na}$ edição de As Horas Nuas lançada pela Companhia das Letras recentemente, Lygia efetuou acréscimos ao parágrafo no qual a citação acima estava inserida. A mudança solucionou a ambiguidade da frase "eu falei pouco", que poderia remeter tanto à existência de Rahul como poeta quanto à de gato, possivelmente extraído do livro do 'Gato de Botas' mencionado. Transcrevo, em seguida, o trecho que sofreu alterações: "O retrato desse Gato de Botas eu vi na capa de um livro lá na casa das venezianas verdes. A roupa do gato era de veludo cotelê verde com um cinto de couro e era belo o chapéu de feltro com a pluma vermelha na aba, eram histórias do tempo em que os animais falavam. É bom lembrar que numa outra encarnação fui aquele jovem romano mas hoje sou este gato que devia usar botas, na opinião de Diogo. Há pouco ele me puxou pelo rabo, até que a dor foi forte mas não soltei nenhum miado, quando fui aquele jovem eu também falei pouco." TELLES, Lygia F. As Horas Nuas. Posfácio de José Paulo Paes. São Paulo: Companhia das Letras: 2010, p.31. Do meu ponto de vista, se por um lado as mudanças solucionaram a referida ambiguidade, por outro, o esclarecimento de que o rapaz na casa romana é o gato empobreceu a passagem que, na edição anterior, é apreendida pelo leitor em meio a uma atmosfera de profundo lirismo e mistério. 
visível e o invisível; em literatura, o gato que apresenta sentimentos humanos apresenta-se "sempre inquietante no plano moral" 250 , como o comportamento dissimulado de Rahul também pode comprovar. Nesse sentido, concordo com a observação de Nízia Villaça de que o gato não pode ser explicado por qualquer recurso ao fantástico ou maravilhoso porque no romance ele é um 'efeito cênico', "um modo de percorrer o lado prosaico da atriz"251. Por isso, cabe analisar a personagem Rahul de acordo com sua verdadeira função na narrativa: a de espelho no romance, com as mesmas propriedades que desde a Antiguidade são conferidas à lâmina refletora, isto é, reproduzir as imagens que de algum modo contém e absorve, na medida em que metaforicamente, através da rememoração, o gato suscita “(...) aparecimentos, devolvendo as imagens que aceitara no passado", ou anula distâncias, "refletindo o que um dia esteve diante dele e agora se encontra bem longe."252

Diogo reconhece que a atriz e seu gato têm um comportamento 'maníaco-depressivo', afirmação que corrobora ainda mais a ligação entre ambos: “(...) Gato e sapato acabam por tomar as feições do dono" (HN, p. 124). Eles apresentam a mesma nostalgia de um passado distante, onde conheceram o amor e a liberdade, com a diferença de que o gato não sente culpa nem remorso pelos feitos de outras vidas; como Rosa, Rahul também usa o humor para reduzir o impacto das constatações da vida cotidiana, que preenchem sua existência e de sua dona de pessimismo: "Se pudesse, passava um telegrama para Diogo Torquato Nave Onde Ele Estiver: Rosa Ambrósio depende de você e eu dependo dela para viver. Ponto. Quer ter a bondade de aparecer? Assinado, Rahul” (HN, p. 67). A atriz e o felino são dissimulados e envergam máscaras das quais nunca se destituem por completo: o gato se considera vingativo e com todos os vícios humanos como todo animal domesticado, como atestam o vômito proposital das bolas de pêlos sobre os tapetes de Rosa e a urina sobre os belíssimos sapatos de Diogo, recém engraxados pela empregada da casa; ele define a atriz como “(...) falsa e verdadeira. Café com leite, impossível separar o leite.” (HN, p. 145)

O gato representa, no romance, o testemunho da passagem dos tempos, assim como a sucessão de personagens vividas por Rosa nos palcos teatrais liga-se à construção de uma história das mulheres rumo à emancipação. Nesse gato, frequentando outros tempos e lugares, a autora implícita encontra novas maneiras de discutir seu próprio tempo - que é o das demais personagens também- na medida em que ele, testemunhando a aflição de Rosa, circunscreve-

\footnotetext{
${ }^{250}$ SIGANOS, André. Bestiário mítico. In: BRUNEL, Pierre (org.). Dicionário de mitos literários. 4.ed. Trad. Carlos Sussekind et al. Rio de Janeiro: José Olympio, 2005, p.127-128.

${ }^{251}$ VILLAÇA, Nízia. O olhar Barroco. In: Paradoxos do pós-moderno: sujeito \& ficção. Op.cit., p. 139.

${ }^{252}$ CIRLOT, Juan-Eduardo. Dicionário de Símbolos. Op.cit., p. 239.
} 
a, apontando, em seu próprio conflito, o mesmo hiato entre passado e futuro, que norteia a vida da atriz: uma pata fincada nas existências anteriores, e outra no desejo ambicioso de, numa próxima existência, voltar a ser Homem. Rahul anseia pela verticalidade, por sair da vida "ao nível do chão" e por essa razão, ele tem necessidade de transcender sua atual condição, assim como Rosa Ambrósio: "Um gato que sonha com o homem assim como o homem sonha com Deus" (HN, p. 151). Encarnando aspectos gerais da condição humana em suas 'transmigrações' - sua relação com o amor, com o medo, com as origens, com a vida em família, com as mulheres -, Rahul mantém um olhar ao mesmo tempo marcado pelo tédio de quem já conhece em profundidade as dores e temores, mas também guarda a secreta esperança de poder reviver, numa nova existência, os prazeres e alegrias daquela mesma condição. De modo semelhante, Rosa, ao representar diversas personagens femininas ao longo da carreira de atriz e diversas máscaras sociais na vida pessoal, tematiza a situação da mulher, da adolescência à velhice, em diferentes épocas, até culminar com a própria representação em um cenário essencialmente urbano, na metrópole que se modernizou e, com isso, aprofundou as desigualdades sociais no mesmo ritmo acelerado dessas transformações ocorridas sobretudo a partir da última metade do século XX.

No universo fragmentado, corrosivo, em que o romance se desenvolve, esse animal com alma humana tem mais consciência que as pessoas que o rodeiam: o 'detentor' de um aspecto da verdade - num contexto em que a noção de verdade é posta em xeque pela própria multiplicidade de pontos de vista-, da versão sem cortes sobre o suicídio de Gregório e a morte da gatinha Lorelai, que cai da janela acidentalmente, por exemplo, é o único ser que não pode falar, embora seja aquele que vê o que ninguém pode. Na condição de narrador, Rahul descreve ações e julga o comportamento de Rosa e de outros membros de seu círculo familiar; mas ele não é mero espectador das ações alheias que revela ao leitor, divertindo-o ou o emocionando; antes, analisa e comenta as ações ou as condições de outros personagens com um tom de 'sabedoria', supostamente obtido pelo aprendizado decorrente das vidas vividas ou inventadas. A dimensão temporal, que justapõe passado e presente e é utilizada pelo gato na posição de narrador e de personagem, reflete tanto seu estado emocional quanto o das personagens que observa.

A autora implícita dota Rahul de um ângulo de visão semelhante ao de Rosa, na medida em que se trata de um olhar que é lançado para o outro com uma 'pata' fincada no próprio eu, olhando para esse outro a partir da visão que apresenta sobre suas experiências pregressas. Dito de outra forma, ele tem a mesma faculdade de Rosa Ambrósio: é capaz de olhar para fora e para dentro de si mesmo, mudando e/ou ajustando o ângulo de visão 
conforme o efeito que deseja revelar ao leitor: personagem ou testemunha... Rahul é aquele que tem uma suposta história de experiências pregressas e, por essa razão, poderia aconselhar, como o narrador clássico, mas, como não pode transmitir essa experiência de vida e de morte às personagens do romance, o faz ao leitor. A atitude questionadora do gato sobre o significado de um possível recomeço vem marcada pelos mesmos sentimentos paradoxais de descrença e esperança que envolvem a atriz quanto à volta aos palcos e a uma nova chance com Diogo $0^{253}$ :

\begin{abstract}
Recomeçar do nada, adiantaria? Não. Logo eu chegaria ao ponto em que estou, o ressentimento. A preguiça. E o mundo igual, igual a crueldade ou mais aprimorada ainda, a técnica aprimora os instrumentos. Atiça a imaginação. A violência da miséria se aperfeiçoando contra as crianças, contra os bichos. Empolgantes as infiltrações sentimentalóides nos discursos. Mas hoje eu sei o que quer dizer esperança, podem perguntar que eu sei. Só não posso responder. $(\mathrm{HN}$, p. 98$)$
\end{abstract}

O gato é, então, um narrador a meio caminho, que se aproxima do narrador benjaminiano quando recorda suas experiências, na medida em que a coisa narrada é mergulhada em sua vida, a do narrador, para em seguida dele ser retirada ${ }^{254}$. Embora tenha memória e as revele ao leitor, afasta-se do narrador memorialista que busca, no narrar, um procedimento de amadurecimento em ordem cronológica, aquele que "fala de si mesmo enquanto personagem menos experiente, extraindo da defasagem temporal e mesmo

\footnotetext{
${ }^{253}$ Na crônica "Papel quadriculado", do livro Durante aquele estranho chá, em que Lygia mistura confissão e ficção, a autora revela sua ligação com Simone de Beauvoir, a partir de sua visita ao Brasil na década de 60 e, posteriormente, quando a própria Lygia esteve em seu apartamento em Paris. Durante o almoço em um modesto restaurante do bairro onde morava, Beauvoir oferece-lhe seu novo livro à época, La Femme rompue (A Mulher Desiludida) e, olhando firme nos olhos de nossa escritora, perguntou-lhe se ela tinha medo de envelhecer. Diante do desconcerto de Lygia, que baixou a cabeça, muda, ensaiando uma resposta, Simone tocou-lhe de leve a mão e constatou que ela estava com medo. Falando pausadamente, Beauvoir afirmara: "todo aquele que faz o elogio da velhice, esse não pode mesmo amar a vida." Lygia termina a crônica com uma reflexão acerca do livro de Beauvoir, que cabe transcrever aqui por ser uma forma não de explicar, mas de iluminar a maneira como ela trata da temática da velhice, da finitude humana e do papel da arte em As Horas Nuas, nas figuras de Rosa e especialmente na de Rahul, em que se faz sentir o pensamento da existencialista francesa: "Ausência de Deus nessa obra. E a presença da fragilidade da condição humana, ah, tanta fragilidade. A insegurança. O medo. E o espanto diante da velhice que rápida ou lentamente vai nos levando para o fim./ A obsessão pelo culto do corpo na esperança feroz (vaidade das vaidades!) de que esse corpo consiga resistir até o infinito. A obsessão pelo culto da arte com a esperança feroz (vaidade das vaidades!) de que a arte, segundo Ernest Becker, seja a negação da morte./ Revejo Simone de Beauvoir com aquele olhar tão sério e tão inquisidor, perguntando. Perguntando. E na obra da escritora está a sua tranquila resposta, obra inteira estruturada na certeza de que a imortalidade seria a morte da própria vida. Só a ideia de que vamos morrer um dia, só essa ideia pode fazer a nossa existência mais feliz.” TELLES, Lygia F. Durante aquele estranho chá: perdidos e achados. Organizado por Suênio Campos de Lucena. Rio de Janeiro: Rocco, 2002, p. 40.

${ }^{254}$ BENJAMIN, Walter. O narrador- Considerações sobre a obra de Nikolai Leskov. In: Magia e técnica, arte e política: ensaios sobre literatura e história da cultura. Tradução Sergio Paulo Rouanet. 7. ed. São Paulo: Brasiliense, 1994. (Obras escolhidas, v. 1).
} 
sentimental (...) a possibilidade de um bom conselho em cima dos equívocos cometidos por ele mesmo quando jovem" ${ }^{255}$ que, em alguns aspectos, é a posição adotada por Rosa na gravação de suas memórias. Com esse recurso, Lygia cria um efeito de nostalgia na elaboração do ponto de vista de Rahul e também de Rosa, que se mistura à sede de resistência ao presente inerte, à crença num futuro repleto de novas possibilidades. Por isso, quando Rosa cantarola sob uma ducha o velho refrão de Frank Sinatra, "Let me try again" [Deixe-me tentar novamente], o gato responde ironicamente com um bocejo: "é o que todos pedem" (HN, p. 39).

O movimento que Rahul faz de personagem a testemunha dá a medida de sua função na narrativa como espelho verdadeiro de Rosa e de observador das demais personagens: é a partir das próprias experiências que ele tece considerações sobre os demais, que sua subjetividade vai sendo construída, aproximando-se do 'objeto narrado' ou mantendo dele uma distância maior. É exemplar a passagem em que esse gato percorre a 'trilha do desejo' no corpo de Rosa, até alcançar a região pubiana, cujos pêlos foram tingidos pela atriz, 'operação' que Rahul lamenta ter testemunhado. Sente seu próprio pêlo se eriçar porque lembra que Gregório

(...) passava a língua por esse corpo na rota do desejo. No tempo do desejo. Vou pateando pelo mesmo caminho tortuoso. Perigoso, ela está inquieta. Desço de novo até seu ventre. $\mathrm{O}$ triângulo sob a seda. Afundo mais nesse ventre, quero seu cheiro e me vem o perfume do talco-jasmim que Dionísia polvilhou com fartura nas coxas, virilhas. (HN, p. 104)

Assim como Rosa, o gato também busca a imagem de seu complemento ideal em uma figura masculina que fizera parte do 'repertório da atriz': Gregório, sua alma gêmea, que ele reconhece como o amante que o subjugou quando era poeta na Roma Antiga. Como observa Vera T. Silva, para o gato, “(...) Gregório corresponde à imagem do Bem-Amado, paralela à imagem de Miguel, no imaginário de Rosa"256. Voltar a um local onde o físico esteve, quer na rememoração do episódio no tempo em que era poeta, quer na repetição dos gestos do amado em Rosa, é uma maneira de reviver um tempo a partir das mesmas sensações mas, como em todas as existências anteriores, há sempre um elemento a impedir sua total revelação, a continuidade de uma relação ou o desvendamento de alguma verdade. Assim como as imagens de seu suposto passado, fragmentos fluidos de uma memória escassa, cujo resíduo

\footnotetext{
${ }^{255}$ SANTIAGO, Silviano. O narrador pós-moderno. In: Nas malhas da letra. Rio de Janeiro: Rocco, 2002, p. 55. ${ }^{256}$ SILVA, Vera M.T. As Horas Nuas, um jogo de deciframento. In: A ficção intertextual de Lygia Fagundes Telles. Op.cit., p. 61.
} 
encontra-se "inalterado feito pedra" (HN, p. 151), que vêm em flashes e escapam ora por um furo no tempo, ora pelo esvanecimento que lhes é próprio, aqui é o perfume do talco que camufla o cheiro da atriz, resquício que poderia levá-lo a comungar a presença/ausência de Gregório, a partir de uma reatualização da experiência vivida.

Na primeira apresentação de Rahul, como poeta, o leitor é levado a compartilhar a descrição de um cenário ao amanhecer que, segundo o narrador, cheira a leite de cabra e mel. Este segue a imagem de um menino por um caminho que já conhece e assiste ao seu rito de passagem ${ }^{257}$ : mergulhando em um rio, rodeado por um bosque com grandes árvores, esse menino, que se revela como o próprio narrador, sai das águas um jovem, visto através do que ele mesmo denomina 'um furo no tempo'. As imagens recriadas e/ou atualizadas pela memória seguem à caracterização de um espaço com elementos que remetem à Antiguidade Clássica, a Roma Antiga, especificamente. Não faltam referências a uma praça rodeada de colunatas, a um filete oleoso colhido numa jarra e à mesa com pés de bronze imitando patas de leão; há uma escada de mármore com veios amarelos e um átrio, além de um jarro de vinho e alguns copos dispostos sobre o tampo de mármore. A cena transcorre ao som de uma cítara e em uma parede dessa casa existe um baixo-relevo com a imagem de um jovem seminu, de beleza viril, montado num touro, que agarra o animal pelos chifres. A atmosfera que esses elementos recriam permite a revelação desse baixo-relevo em seguida como a metáfora da entrega desse jovem, que é poeta, ao amante que o toma ferozmente, ambos nus, em profundo gozo. O cuidadoso trabalho de descrição desse ambiente impressiona pela capacidade que o personagem tem de estar fora e concomitantemente dentro das cenas relatadas, na medida em que ele pode olhar com um certo distanciamento as imagens projetadas, pois consegue delinear a relação sexual repleta de liberdade e livre de preconceitos dos dois rapazes, como se estivesse de posse de uma câmera, ao mesmo tempo em que ele é sujeito, participante daquelas cenas, fazendo o leitor compartilhar as sensações vividas por esse 'narrador', oriundas daquele episódio. Rahul escapa de seu corpo pelo 'funil' do grito de orgasmo e percebe que entre seu corpo físico e o que chama de "si mesmo" há uma espécie de parede de vidro, através da qual vê também o corpo do amante. Os "corpos sutis" se evaporam e se dissolvem, e suas cores escorrem até se "infiltrarem no nada", como são as próprias imagens recriadas pela memória, reforçando o efeito de aproximação e distanciamento, exposição e ocultamento.

\footnotetext{
${ }^{257}$ Liem Alcântara faz uma análise desse rito de passagem pela via simbólica em sua tese de doutorado. Cf. ALCANTÂRA, Liem Hani. Palavra: rota de salvação em Xerazade e Os Outros e As Horas Nuas. Op.cit., p. 103-104.
} 
Do mesmo modo, o cheiro do pão quente feito em casa que Dionísia colocara na vasilha de Rahul, leva-o a 'regressar' a um tempo anterior ao do poeta romano. O gato "trabalha" cada migalha do pão, mastigando-o lentamente, na esperança de que nele restara algum resíduo daquele tempo:

"Eu vi a vida nascer da morte", soprou uma voz. Fiquei em suspenso diante de duas grandes mãos da cor do ocre, trabalhando pacientes na argila como eu próprio trabalhara no pão. Assim que me aproximei elas se esvaneceram. Ficou a vasilha do gato com um pouco de farelo no fundo. (HN, p. 30)

Em outra passagem, Rahul 'recorda-se' da promessa de Deus de que Ele daria um novo corpo a todo aquele que o merecesse, momento em que o gato refere-se à segunda vida que recebeu e que dela saiu morrendo ainda jovem, por overdose, no hospital: "Ficou tão pouco dessa vida breve, não é fantasia, eu sei que esse pouco se divide e multiplica em outras lembranças com a rapidez dementada das imagens do caleidoscópio" (HN, p. 59). A técnica narrativa de Lygia costura as lembranças que habitam os mais recônditos espaços da alma de Rahul nos lugares revisitados pela memória, num olhar que insiste em dilatar os instantes vividos com êxtase para que melhor sejam apreendidos, imitando o mesmo movimento que a protagonista realiza, buscando investigar, no passado, as motivações capazes de explicar o momento presente. Os objetos, os aromas, os sabores de outros tempos e vivências são trazidos à tona graças à habilidade proustiana de entrelaçar a memória da lembrança com a memória do sentimento, o que permite a atualização do vivido, carregado de lirismo e saudosismo. Essa visão nostálgica também toma conta de Rosa diante do gradativo afastamento do coletivo e do divino, em favor de sociedades cada vez mais individualizadas e individualistas, quando se chega ao limite do individualismo narcísico em tempos recentes. $\mathrm{O}$ comportamento do gato, portanto, encontra eco justamente no queixume da protagonista sobre a "desmitificação dos mitos e a massificação dos heróis", que problematiza a dialética de esconder e mostrar que estrutura a construção de Rosa, Rahul e Ananta e do próprio romance como um todo. Tomemos como exemplo a referência que a protagonista faz à "Igreja de sua infância", que com o passar dos tempos tentou se aproximar da realidade do povo, exagerando na dose de modernidade de seus rituais. A atriz rememora e compara as diferentes imagens da nova e da velha igreja, revelando inclusive a contradição que se estabelece entre seu discurso e sua condição de burguesa alienada:

A Igreja da minha infância também era diferente (...). As novenas com a mamãe. Uma noite coroei a Virgem, o resplendor de ouro na almofada de 
veludo. O incenso denso, o mistério. Uma Igreja conhecida e desconhecida. Quis ficar banal, a pobrezinha, atrair depressa os jovens, conquistar operários. (...) Conquistou? Conquistou nada e ainda perdeu os velhos. (HN, p. 117)

Paralelamente à desmitificação de um sistema religioso, à simplificação dos rituais, da "simbologia que Deus exige" (HN, p. 119), ao fim dos gestos e das palavras secretas, esvaídos de sua aura de mistério, de impenetrável, a industrialização crescente e ampliação dos mercados de consumo criaram as condições necessárias para a padronização de gostos, crenças, valores, massificando os 'heróis', sejam eles representados pelo cinema ou criados pela imprensa, exaurindo-os igualmente de traços particulares, singulares que os diferenciassem da grande massa. Por essa razão, quando Rosa questiona Dionísia se é chegado o fim dos mitos e dos heróis, a protagonista mesma afirma que a empregada já respondeu "quando pulverizou minhas partes (...) com o desodorante da moda" (HN, p. 119).

Embora se considere um gato "memorialista e agnóstico", a viagem por diferentes existências anteriores é uma tentativa encontrada por essa personagem errante de voltar a um tempo memorável, de experiências no sentido da fusão com o que se lhe afigura como sagrado. É a desarticulação das reminiscências no tempo e no espaço - a maioria, no entanto, ligada a um tempo anterior e mítico, primordial, seja na rememoração ou invenção da cena da criação escatológica, seja no tempo em que conheceu o amor na Roma Antiga ou a ausência do pai na casa das venezianas verdes, que sua experiência acumulada não é única e nem historicamente datada como a da velha atriz, que sofre, na velhice, com as exigências de uma nova sociedade em tempos de exacerbação da cultura do corpo belo e jovem. Essa mesma nostalgia dos bons tempos vividos tem, para Rosa, um sentido diferente da de Rahul - a de guardar da vida apenas as horas felizes, sinal de que lhe é difícil aceitar, com a experiência de outras vidas, representadas no palco na condição de atriz, que a dor e o sofrimento, juntamente com as alegrias, são partes indissociáveis da natureza humana. Ambos clamam por um retorno ao Paraíso Perdido, ao local que não conheceu a hostilidade do mundo, como a casa do poeta romano e a residência da infância representam para o gato e a atriz, respectivamente, na medida em que a função do espaço é, segundo Bachelard, reter o tempo comprimido..$^{258}$

Nas recordações de Rahul, as imagens primordiais arcaicas ali presentes correspondem às imagens míticas, intimamente relacionadas com os mistérios da origem, da

\footnotetext{
${ }^{258}$ BACHELARD, Gaston. A poética do espaço. Op.cit., p. 28.
} 
vida e da morte, e que são parte mesmo da literatura. A ideia de renascimento, tão cara às personagens lygianas, encontra no simbolismo dos mundos animal, vegetal e mineral a ponte a ligar o mundo exterior e o interior.

(...) a vida civilizada associa-se frequentemente com o ciclo orgânico de crescimento, maturidade, declínio, morte e renascimento em outra forma individual. Enquadram-se aqui os temas de uma idade de ouro ou heróica no passado, de um milênio no futuro, da roda da fortuna nos assuntos sociais, da elegia do ubi sunt, das meditações sobre ruínas, da nostalgia por uma perdida simplicidade pastoral, da lástima ou exultação pela queda de um império. ${ }^{259}$

Rahul, assim como Rosa, também se afasta da sociedade em que vive em sentido oposto: pela condição de animal, o gato permanece na esfera trágica do isolamento, condição a ser transformada pela morte, que possibilitará o retorno à condição de 'gente':

E se eu tivesse que morrer para nessa segunda oportunidade me aproximar dele [Gregório] novamente? Se é que a gente pudesse se reencontrar - eu disse a gente? Eu disse a gente. Porque a idéia de ser de novo um bicho é tão dilacerante que continuo a me perguntar, no mesmo tom culposo da Rosona, o que eu fiz, o quê?! para merecer esta forma. E não tenho fé, não acredito em nada. Um gato moralista e agnóstico - existe? Memória que quase sempre é peçonha na qual me alimento. E me enveneno. Recuei. Saltei para o tapete. Agora tenho medo da liberdade. (HN, p. 129-130)

Memória e desejo de liberdade que também envenenaram e amedrontaram Gregório e o levaram à morte, mas que é espelho de vida para seu gato. O processo de transformação almejado pelo gato visa à anulação de sua natureza animal, à medida que sua consciência torna-se mais crítica e percebe, na possibilidade de morte, a esperança de superar aquela condição. Essa possibilidade de metamorfose, que mantém o grão do primordial, do original, claramente se revela como um modo de preservar viva a memória, como forma de sobrevivência das experiências que marcam a condição humana, como o amor, a paixão, o medo, a morte. A semelhança do discurso de Rahul com a forma de Proust narrar se dá pelo reencontro com a realidade perdida na memória, liberada por um acontecimento exteriormente insignificante e aparentemente casual, o que também ocorre com a atriz. O que diferencia o processo do felino, comparado à técnica utilizada pelo escritor francês, é que o gato não confia na direção da sua própria consciência, pois duvida e questiona a objetividade e a essência do acontecido: memória ou invenção? Ao questionar os limites movediços entre

${ }^{259}$ FRYE, Northrop. Anatomia da crítica. Op.cit., p. 160-161. 
história e memória, fato e imaginação, a personagem aciona a dúvida quanto à validade de suas próprias lembranças ${ }^{260}$, ao mesmo tempo em que conduz o leitor a questionar as de Rosa Ambrósio.

Numa linguagem carregada de lirismo, as imagens que remetem a suas outras existências, inventadas ou não, parecem ajustadas e recombinadas como aquelas do caleidoscópio que Rahul vira quando era um menino na casa das venezianas verdes, provavelmente junto com sua mãe. Numa tarde, o gato encontra Diogo deitado nas almofadas de um canapé contemplando o mesmo objeto. Esse episódio coloca em questão a primeira dúvida sobre a natureza das reminiscências do gato: “O caleidoscópio que o menininho viu não seria esse mesmo que Diogo achou nos guardados de Rosona? Não havia dois caleidoscópios mas apenas um, inventei o outro?” (HN, p. 59). Ou quando associa a figura decadente de Rosa à mulher enlutada que enlouquecera, a figura materna do menino de cachos: "Acho que um dia ela foi a minha mãe" (HN, p. 105). Esse brinquedo infantil, cujo mecanismo de funcionamento tem por base um jogo de espelhos no interior de um tubo cilíndrico que produz múltiplas imagens simétricas, suscita a reflexão sobre o mecanismo que delineia o papel de Rahul como espelho de Rosa, mas também acerca do aspecto metaficcional que seu discurso encerra. A digressão autorreflexiva a que ambos, atriz e gato, se submetem chama atenção para a natureza mesma dessa digressão, nos limites entre invenção e memória, em que a 'verdade' sempre vem misturada a uma dose de imaginação e, portanto, de subjetividade. As evidências disso encontram-se já nas epígrafes que abrem o romance - a frase de Drummond e o trecho do evangelho de São Mateus, respectivamente: "De tudo fica um pouco. Não muito" e "Abrirei em parábolas minha boca e dela farei sair com ímpeto coisas ocultas desde a criação do mundo". A referência à memória, impossível de ser apreendida em sua totalidade, e a menção a uma forma textual como a parábola, que transmite um ensinamento a partir de uma narrativa figurada, assim como as fábulas, são formas de escapar, no romance, ao pessimismo e ao caos que se instalaram no Brasil com o fim das utopias, com o avanço da indústria da cultura e com o individualismo exacerbado que desembocou na derrocada dos projetos coletivos. Assim sendo, se por um lado a estrutura formal das narrativas maravilhosas praticamente desaparece na literatura contemporânea, por outro o 'tom romanesco', com sua típica nostalgia por "uma idade de ouro imaginativa no

\footnotetext{
${ }^{260}$ Essa também é a visão de Nelly N. Coelho: “(...) É devido à sua voz narrativa que a fusão vida/arte ou a oposição invenção/realidade se revelam mais claramente. Aprofundando as dúvidas ou perplexidades do leitor, com relação ao que lhe está sendo contado, o gato Rahul, a cada momento, põe em questão a autenticidade de sua própria fala." COELHO, Nelly N. As Horas Nuas: a falência da razão ordenadora. In: literatura feminina no Brasil contemporâneo. Op.cit., p.239. (org.). A
} 
tempo e no espaço" infiltra-se no romance, provando, como revela Frye, que "não importa a extensão da mudança que possa ocorrer na sociedade, a estória romanesca (sic) surgirá de novo, tão faminta como sempre, procurando novas esperanças e desejos de que alimentarse." ${ }^{261}$

Rahul assemelha-se ao homem primitivo, possuidor do "pensamento mágico", “criador de mitos", primeira manifestação do pensamento religioso ${ }^{262}$. Ele tenta explicar sua gênese criando relatos de outras vidas. Embora não acredite em Deus, tem vislumbres da criação quando lembra de duas mãos da cor do ocre trabalhando a argila. Não é gratuito que uma das fontes das narrativas que cria a respeito de sua própria origem seja o mundo antigo greco-romano, que tem uma complexa mitologia ${ }^{263}$. No lugar dos deuses, figuram seres de carne e osso, destituídos de quaisquer qualidades mágicas ou sobrenaturais: a imagem primordial é a de um poeta romano, cuja existência está ligada ao local onde a personagem conheceu o amor; a segunda grande 'recordação' remete à vida como um menino de cachos, em que viveu com as três mulheres da casa das venezianas verdes, sem o pai. A última lembrança como ser humano é a de um rapaz morto por overdose de heroína em um hospital, espaço de dor e sofrimento. As lembranças dessas vidas anteriores projetam-se através de conjuntos de imagens que se movimentam de um mundo idealizado para um mundo não idealizado, que por analogia corresponde ao que Frye entende como o deslocamento do mito em uma direção humana, em contraste com o realismo. Por isso, na construção de Rahul, é possível sentir aquele 'tom romanesco' que mencionamos anteriormente, em meio ao plano realístico de suas experiências passadas e as de Rosa, as quais surgem como forma paródica que contrasta justamente com as histórias romanescas. Portanto, assim como o poeta ou o herói no período em que essas histórias vigoravam como gênero, Rahul tem por função, na atual existência, recordar e contar. Quando seu pensamento é revelado, mostra-nos aquilo que nem ele nem seus leitores devem esquecer: as ligações que o ser humano estabelece com o universo e com a própria vida. É deste modo que o gato se configura como personagem e como testemunha no romance: como criador de histórias capazes de explicar sua gênese e a de seu mundo e como narrador de experiências, à espera de novos acontecimentos, remetendo à 'nova consciência do escritor': “dono absoluto de seu mundo de ficção, com plenos poderes

\footnotetext{
${ }^{261}$ FRYE, Northrop. Anatomia da crítica. Op.cit., p.185.

${ }^{262}$ COELHO, Nelly N. Literatura Infantil. Op.cit., p. 151.

${ }^{263}$ Ibid., p. 151.
} 
para inventar realidades, torná-las reais para o leitor, e em seguida destruí-las ao denunciar seu jogo ou sua mistificação."264

Pela janela da sala de estar, Rahul costuma contemplar a noite estrelada e a Lua, paixão de Gregório e sua também. O universo pessoal do gato e da atriz é regido pelo princípio feminino, lunar, que representa o revés do caráter masculino da cultura, solar, do mundo da acumulação de capital. Neste, “a vitória da razão sobre o mito é (...) o sucesso na tarefa de deixar os instintos sob o controle desse tribunal competente que é a Razão da Dominação: repressão da natureza exterior e interior ao homem"265. Na relação com Gregório, Rosa ocultara suas características lunares, fazendo vigorar o aspecto solar, ativo, masculino que norteou sua vida pelos caminhos da ambição e da desagregação familiar. Somente quando a atriz se reconhece como uma 'mulher cheia de carências e aparências', é possível identificá-la com os atributos lunares, fase que coincide com o presente da narrativa. A Lua, por conseguinte, liga o gato a Gregório porque ela é símbolo do 'eterno feminino', do caráter feminino da cultura, que, por sua vez, é "representante da receptividade, da sensibilidade, da não-violência, da ternura - qualidades incompatíveis com a sociedade produtivista, agressiva e competitiva" 266 que Rosa, até certo ponto, representou. Essas características são as mesmas que se observam no amante da casa romana, bem como em Gregório. Há, no entanto, outros aspectos simbólicos que ligam Rahul àquele astro celeste.

A Lua é o astro dos ritmos biológicos, da lei da mudança, do crescimento à decrepitude, já que existe uma periodicidade sem fim do eterno retorno às suas formas iniciais. Ela está submetida à lei universal do devir, do nascimento e da morte e, por isso, é considerada como símbolo da passagem da vida à morte e da morte à vida ${ }^{267}$. Nesse sentido, a crença de Rahul em uma nova existência é sugerida pelo reconhecimento que o homem faz de sua vida na vida do astro, já que “ela torna válidas, graças à 'lua nova', a sua sede de regeneração, as suas esperanças de renascimento"268, de vencer a morte. Os questionamentos do felino coadunam-se com os da atriz em uma vida nova, expressos na esperança de que o 'corpo sutil' de Gregório não tenha ficado sob a organza lilás que cobria seu corpo no caixão:

\footnotetext{
${ }^{264}$ COELHO, Nelly N. As Horas Nuas: a falência da razão ordenadora. In: no Brasil contemporâneo. Op.cit., p.239-240. (org.). A literatura feminina

${ }^{265}$ MATOS, Olgária. Masculino e Feminino. Op.cit., p. 133.

${ }^{266}$ Ibid., p. 134.

${ }^{267}$ CHEVALIER, Jean; GHEERBRANT, Alain. Dicionário de símbolos. Op.cit., p.563.

${ }^{268}$ ELIADE, Mircea. Tratado de história das religiões. Tradução Fernando Tomaz e Natália Nunes. 2.ed. São Paulo: Martins Fontes, 1998, p.130.
} 
Em alguma parte ele está me esperando, sim, que não me venha aquela suspeita. Aquela. De que ele ficou lá mesmo onde o deixaram, tão quieto, sem a bendita fúria da rebelião, da ruptura, Gregório, não admita isso! grito e a massa ignóbil, a massa tristíssima, esvaziada. E habitada, Gregório, reaja! (HN, p. 108)

A etapa de invisibilidade da Lua no céu por três noites corresponderia à da morte no homem, o qual adquire uma nova modalidade de existência, isto é, "a morte (...) não é uma extinção, mas uma modificação- frequentemente provisória- do nível da existência"269. A Lua revela, portanto, para o homem, assim como para Rahul, "a sua própria condição", na medida em que o mundo sublunar é o mundo das transformações, mas também o dos sofrimentos, da história. $^{270}$

Rahul também divaga sobre as mulheres sempre ao seu redor, das quais, como a atriz, não gosta. Ele percebe sua presença desde os tempos remotos onde conheceu o amor: as invisíveis, discretas, na casa romana; a irmã, a agregada e a mãe enlouquecida na casa das venezianas verdes; uma mulher de olhos verdes em sua alcova; as mulheres atuais, Rosa, Cordélia, Dionísia. É possível vislumbrar, nos breves e velados comentários de Rahul sobre essas mulheres, a mesma trajetória da figura feminina que parte de uma situação de completa invisibilidade rumo à sua emancipação, mas construída sob outro viés com relação às personagens encenadas por Rosa no palco, na função de atriz, como vimos no segundo capítulo deste trabalho. Apesar da queixa do gato, ao contrário delas, os homens e os fantasmas sempre se despedem - elas resistem, permanecem: "As mulheres que me confundem e me escapam, mais perigosas do que os homens na conspiração (...). Mais vulneráveis no vício. No amor. Acredita Ananta Medrado que elas serão as únicas capazes de salvar esta vida sem qualidade. Este mundo" (HN, p. 145). Essas revelações envolvem um aspecto fundamental da capacidade visionária do gato, que consegue ver alguns espectros que circulam pelo apartamento, fato intimamente relacionado com a ligação entre a lua e a noite, quando o astro emana sua luz lívida por sobre os objetos, semidesvelando-os ${ }^{271}$. Dentre tais espectros, encontram-se o da mulher do pente espanhol, o do homem de chapéu-coco, o de Gregório e o da menina antiga, cuja descrição física revela elementos que lhes eram característicos e que permitem reconhecê-los como elementos dispostos na casa da atriz ou entes de Rosa, figuras que foram importantes em sua vida pessoal e profissional. A mulher

\footnotetext{
${ }^{269}$ ELIADE, Mircea. Tratado de história das religiões. Op.cit., p. 141.

${ }^{270}$ Ibid., p. 151-152.

${ }^{271}$ CIRLOT, Juan-Eduardo. Dicionário de símbolos. Op.cit., p. 354.
} 
usava um xale de seda, um pente espanhol preso aos cabelos, uma pesada maquiagem de palco, com olheiras esverdeadas e deixava no ar um perfume adocicado e enjoativo, sentido inclusive por Dionísia, o que dá um toque de mistério à aparição vista apenas pelo gato. Seus gestos denunciam, no andar de um lado a outro, no atravessar a porta com arrogância, na mão que massageava o pescoço, as preocupações que a atormentam. O velho de chapéu-coco, sempre a examinar o céu e a cumprimentar cordialmente o gato, usava um pince-nez preso a um cordão preto, de aros redondos e lentes escuras, botinas engraxadas e abotoaduras de ouros nos punhos brancos, com colarinho alto e duro. $\mathrm{O}$ espectro de Gregório com seu cachimbo, vestido com o terno do enterro, repete os mesmos gestos anteriores aos do suicídio: permanece sentado, lendo sob a luz do abajur, estende a mão para afagar o felino ou procura algo nas estantes ou nos bolsos. Já a menina antiga de maneiras educadas, que observa tranquilamente a porta como se esperasse por alguém, usa um vestido de tafetá, botas de pelica branca e dispõe sobre o regaço um bordado dentro de um bastidor. Diante de tais aparições, Rahul questiona a relação existente entre a menina antiga com as pessoas de sua casa e com a cantora do pente espanhol.

As referências espalhadas pelo apartamento de Rosa funcionam como os pequenos pedaços de vidro colorido a refletirem suas luzes nos espelhos do caleidoscópio narrativo de As Horas Nuas, na medida em que se constituem em pistas que o leitor precisa juntar para compreender o significado dos espectros. Na parede do antigo escritório de Gregório havia, por exemplo, um pôster da atriz Sarah Bernhardt "com olheiras roxas e roupagens de drama", referência teatral importante para Rosa e que mantém similitude, pela descrição física, com a mulher do xale, de maquiagem pesada e olheiras esverdeadas. Mas a presença dessa mulher mantém uma ligação com a figura materna de Rosa, de 'olfato de vidente', com quem a atriz simula um diálogo durante uma bebedeira, afirmando ter sentido sua presença como uma sombra que se inclinara sobre a poltrona para beijá-la. Sem ouvir as respostas para os questionamentos feitos à mãe, a protagonista declara: "Ela não está nem nunca esteve nesta sala" (HN, p. 154). Outro vestígio liga-se à confissão que Rosa fizera à sua analista de que gostaria de bordar como aquelas mulheres que bordavam e que pareciam "tão calmas fazendo almofadas, tapetes. Ou era tudo fingimento? As mulheres não seriam mais felizes se bordassem?" (HN, p. 136). Isso permite associar a menina antiga ao desejo de Rosa voltar à infância, ao tempo de sua mãe, em que as mulheres dedicavam-se aos afazeres domésticos, atravessando o risco do bordado com a linha entremeada às suas possíveis angústias e prazeres e oferecendo uma imagem pública de calma e tranquilidade. Isso se coaduna com a lembrança de Rosa sobre a estampa de uma marquesinha de vestido de seda e sapatos de 
cetim, que sua mãe mandara enquadrar e que depois foi parar no quarto de Dionísia, que reaproveitou a moldura. Essa representação da marquesinha, evocada a partir da lembrança de Rosa ainda criança na casa da mãe, remete ao desejo da protagonista de reviver, na condição atual, outros tempos menos caóticos, como sua própria infância: “(...) A vida amena. Fagueira. Tinha a guilhotina, mas não tinha a bomba atômica. Nem Aids. (...)” (HN, p. 45)

O homem de chapéu-coco, pela maneira como aparece trajado, provavelmente viveu na primeira metade do século XX e, apesar de trazer abotoaduras de ouro, como as de Gregório, encontradas por Rosa quando se desfez dos objetos do marido, pode estar ligado ao avô da protagonista ou à sua figura paterna, por quem ela clama em seus delírios alcoólicos e/ou sonhos. Os sinais deixados por Lygia como autora permitem responder à indagação do gato a partir mesmo de como esses fantasmas se esvanecem, exceto o da menina:

O velho do chapéu-coco, a mulher do xale, Gregório com seu cachimbo demonstraram todos nas suas aparições que a alma ou corpo sutil, tenha isto o nome que tiver, vai se desfazendo antes ainda de se desfazer o corpo material. Destinados ambos à destruição mas em tempos diferentes. (HN, p. 130)

Nesse sentido, é esclarecedor destacar que o termo espectro apresenta duas acepções fundamentais: remete tanto ao conceito de fantasma quanto ao de recordação obsessiva. Ao longo do romance, a atriz lembra-se da vida em outros tempos e de seus entes queridos com saudades e/ou culpa, mas à medida que o exercício da rememoração apara arestas do passado, essas figuras que apareciam de modo mais ou menos intenso no monólogo da atriz, testemunhado por Rahul, perdem o estatuto de ideia fixa para restarem apenas como fragmentos fluidos no plano da lembrança, como parte da memória que Rosa quer preservar. Isso confirma a observação de Frye de que nas formas de ficção irônica, como em As Horas Nuas, "o espectro começa a voltar como fragmento de uma personalidade em desagregação" 272 . E aqui o tempo é o grande aliado no processo de desligamento entre o ser e a recordação que evoca porque apresenta a função ambígua de inimigo e redentor das personagens:

(...) o reino do ser é o não-esquecimento, a aparição (alethéa); toda negação de ser vem da manifestação da Noite de seus filhos, entre eles, o Esquecimento (léthe, lesmosyne). A linguagem (...) é filha da Memória, ou seja: deste divino Poder trazer à Presença o não-presente, coisas passadas e futuras. (...) O ser-aparição portanto dá-se através da linguagem, ou seja: por

\footnotetext{
${ }^{272}$ FRYE, Northrop. Anatomia da crítica. Op.cit., p.56.
} 
força da linguagem e na linguagem. (...) É na linguagem que impera a aparição (alethéa) - e também o esquecimento. ${ }^{273}$

O felino que circula pelo apartamento e pelo prédio e ouve diversos lamentos e confissões, por sua vez, trabalha a matéria ouvida, assim como o escritor o faz com os elementos e/ou fatos que o circundam, criando uma nova realidade. Por isso, os espectros são formados da mesma matéria das recordações de suas existências anteriores, isto é, um misto de fatos objetivos e matéria subjetiva, memória e invenção. Assim, o recordar tem a propriedade de elixir que revigora a vida da atriz e de seu gato.

Diante do que foi exposto, é possível apreender mais uma faceta do jogo de representação de As Horas Nuas: o processo de escrita é uma luta para manter o corpo sutil da condição humana eternizado no corpo material que é a palavra escrita. Se apenas o espectro da menina antiga resiste, é porque, como representação dos desejos mais profundos da protagonista, ela vence o esvanecimento de sua imagem pelo bordar, pela impressão de sua marca no tecido limitado pelo aro do bastidor, metáfora da poética memorialista/feminista da escritora, que, pelo exercício da palavra, evoca voluntária ou involuntariamente memórias individuais e coletivas, representações femininas do presente nas quais reverberam as do passado, em permanente diálogo. Mas há ainda outro aspecto dessa poética que se organiza em torno de Rahul, espelho da protagonista. Como figura do sexo 'masculino', com alma humana e opção homossexual, e único ser que tem a capacidade de olhar para além de sua condição e a dos outros personagens devido à sua visão profunda sobre a existência humana, Rahul desestabiliza a velha máxima de que apenas o 'homem' representa a humanidade, estratégia da autora que desconstrói e subverte os papéis de gênero culturalmente preestabelecidos de quem pode contar e mostrar, seja na vida, seja na ficção.

E assim também como do volúvel Gato de Cheshire, das Aventuras de Alice no País das Maravilhas, o grande sorriso é sua última marca a se esvanecer, em As Horas Nuas fica eternizada a última imagem do romance, a figura de Rahul atrás da vidraça do apartamento de Rosa, que, flertando com a face oculta da vida, convida o leitor a penetrar no outro lado do espelho, a entrar no mundo da imaginação e da fantasia para descobrir, através da arte, a transcendência de sua própria condição.

\footnotetext{
${ }^{273}$ TORRANO, Jaa. O mundo como função das Musas. In: HESÍODO. Teogonia: a origem dos deuses. 7. ed. São Paulo: Iluminuras, 2007, p. 29.
} 
(...) As correspondèncias familiares e a literatura 'pessoal' (diários intimos, autobiografias, memórias), embora sejam testemunhos insubstituiveis, nem por isso constituem os documentos 'verdadeiros' do privado. Elas obedecem a regras de boas maneiras e de apresentaçáa de uma imagem pessoal que regem a natureza de sua comunicaģấo e o estatuto de sua

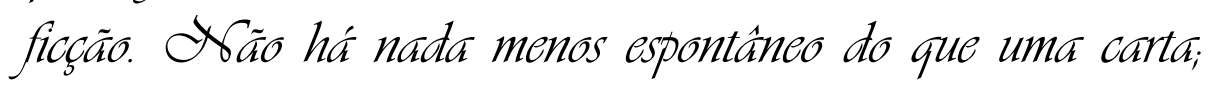
nada menos transparente do que uma autobiografia, feita para ocultar tanto quanto revelar. Chas essas sutis manipulacốes do esconder/mostrar nos levam, pelo menos, à entrada da fortaleza.

(Ohichelle Derrot. OHistónia da vida privada) 


\section{MEMÓRIAS "DESLUMBRANTES"}

A mulher é, no Brasil, o melhor tema de si mesma. ${ }^{274}$

\subsection{Histórias em família}

o décimo quinto capítulo, a dois do término do romance As Horas Nuas, o
leitor se depara com Rosa Ambrósio vivendo um estado de euforia porque, enfim, aconteceu o que tanto desejava: seu ex-secretário e amante, Diogo, telefonara. $\mathrm{O}$ entusiasmo pela certeza de sua volta é tamanho que ela interrompe a bebedeira a que se entregara e, começando a cumprir sua promessa, prepara-se para a volta do amado: aposta no poder de uma ducha, por tanto tempo protelada; volta aos cremes e às saunas; retira os vestidos brancos dos armários e chama a cabeleireira/manicura para retocar os cabelos e deixar as "unhas claras e sem manchas nem por dentro nem por fora"; alvos também deveriam estar os dentes e com um perfume de hortelã o hálito. Até a "máscara da soberba" (HN, p. 197) resolveu tirar diante de Dionísia, substituindo a personagem que não dera importância ao comunicado de que o amante telefonara por seu verdadeiro entusiasmo; afinal, quem acreditaria naquela indiferença, Rosa se questiona. Dirige-se ao escritório, acende um incenso, liga o toca-discos e ouve o saxofonista que Diogo adorava. Resolve, enfim, dar início ao que ela intitula um capítulo de suas memórias, um 'depoimento-capítulo'(HN, p. 200) que concede a um gravador, e não à sua 'muleta de vidro', a analista Ananta Medrado, a jovem médica que desaparecera misteriosamente do consultório/apartamento em que morava, no mesmo edifício de Rosa.

É com a lembrança de uma frase enunciada pelo marido morto - Carpe Diem! - que ela, com a mesma energia que a frase lhe sugere, inicia esse capítulo, numa tentativa de aproveitar o tempo perdido, diante da fugacidade da vida. No amor platônico que quer viver com Diogo - como vimos, sem sexo, mais próximo de um estado de alma do que da aproximação física - está sugerida a fonte dessa energia capaz até mesmo de recuperá-la do alcoolismo e do processo de degeneração ao qual se entregou. Continua a gravação das

\footnotetext{
${ }^{274}$ SQUEFF, Enio. Timidez e afirmação da escritora brasileira. In: O Estado de S. Paulo. Op.cit., p. S. - 19.
} 
memórias, aludindo ao desaparecimento de Ananta e às mãos trêmulas de Gregório. De modo brusco, interrompe o fluxo verbal, pois se dá conta de que não era 'bem isso' o que ela gostaria de dizer: “(...) calma, Rosa Ambrósio, não misture as coisas, fique calma, você começou anunciando que aconteceu afinal o que tanto esperou, o que tanto pediu, o Diogo telefonou." (HN, p.196)

O projeto de escrita das memórias de Rosa Ambrósio é anunciado ao longo dos capítulos que antecedem à gravação, às quais a personagem daria o título de As Horas Nuas. No exercício da rememoração, a protagonista transforma sua experiência em algo transmissível, construindo, com isso, sentidos para essa experiência e afirmando-se como sujeito. A atriz dá início ao que acredita ser um 'balanço de ganhos', permeado por pequenas amostras da rica subjetividade construída nos capítulos anteriores por meio do monólogo interior da personagem, do alto do processo de decadência a que se entregou. Nessas pequenas amostras ditadas ao gravador, desfilam outras lembranças, apenas as que ela considera boas, com as quais o leitor, já acostumado com a matéria das páginas precedentes, não se surpreende. Por essa razão, os capítulos 15 e 16, que correspondem em quase sua totalidade às memórias gravadas, surgem, aparentemente, como que isolados do conjunto do romance como um todo. Silviano Santiago, em crítica ao último romance da escritora paulistana, corrobora essa posição, ao afirmar que os capítulos finais de As Horas Nuas 'rendem pouco' ao romance:

Da mesma forma como o personagem de Ananta (com todas as implicações dramáticas) pouco contribui para a fibra do romance, também as diversas páginas do final dedicadas ao amor juvenil de Rosa pelo primo Miguel, precocemente falecido, pouco rendem no conjunto do romance. As reminiscências históricas (a alta burguesia paulista e a $2^{\text {a }}$ Grande Guerra), a arqueologia da artista (Rosa vai a uma festa de casamento 'fingindo' que não sabe da morte do primo) etc., são momentos dramáticos que escapam à coragem, à ousadia e ao desrespeito juvenil das páginas iniciais. ${ }^{275}$

O comentário do crítico poderá parecer bastante convincente e elucidativo, entretanto, se não nos detivermos na função que tais capítulos têm no conjunto do romance. Do ponto de vista narratológico, tais memórias têm a função de concluir o 'ciclo' Rosa Ambrósio, fornecendo ao leitor informações sobre fatos marcantes ocorridos durante seu processo de formação, uma releitura de seu passado voltado para a fase fundamental na constituição de sua personalidade, ou, para dizer com Simone de Beauvoir, a etapa "em que o mundo adquiriu

${ }^{275}$ SANTIAGO, Silviano. Romance traz o tango das ilusões perdidas. Op.cit.. 
uma fisionomia a seus olhos"276: a infância. Uma leitura calcada unicamente nesse princípio, porém, escamoteia o que de mais recôndito subjaz a essas memórias. É necessário, portanto, compreender tanto o conteúdo dessas memórias quanto seu mecanismo de reconstrução, em sua mais íntima ligação com as relações familiares e profissionais as quais a personagem estabelece no presente da narrativa, na medida em que a protagonista confere o estatuto de 'paraíso' a um período marcado pela inocência e pelo sonho, mas também de sofrimento, na tentativa de comunicar uma experiência tão importante por ela 'esquecida'.

De início, se adentrarmos atentamente nessas memórias, já salta aos olhos o fato de que a lembrança de Miguel, primo e namorado de Rosa na adolescência, e de sua família, é muito mais vívida nas breves, mas pungentes menções anteriormente feitas, do que no vasto relato que ocupa quase completamente os dois capítulos que se referem à produção das memórias propriamente ditas. É curiosa a referência que Rosa faz ao primo no início do romance como “aquela lembrança tão esgarçada, verdade ou invenção?” (HN, p.11), em contraponto aos outros dois homens que marcaram sua vida, Gregório e Diogo, figuras recorrentes em quase todo o seu extenso monólogo. A perda de contato com aquela família, ocorrida pela morte de seus membros, é o motivo mais evidente do esquecimento desse período da vida de Rosa, mas a incorporação de seu repertório pessoal ao profissional, no sentido de sua integração à mesma classe social a qual pertenciam seus tios e primo, também pode explicar seu questionamento sobre a existência ou não da figura do primo. Miguel, no início de As Horas Nuas, parece não ter sido uma figura tão importante na vida da atriz, mas a recuperação dessa experiência se dá de modo breve e lentamente ao longo do romance para emergir com força durante a gravação das memórias. Tomemos o episódio em que "aquela lembrança tão esgarçada' começa a ganhar corpo, muitos anos depois, num momento recordado pela atriz, em meados do romance, na posição de narradora protagonista, em que ela e Diogo estavam juntos em uma praia: ao ver o amante com as mãos em garra, puxando para trás os cabelos molhados, Rosa reconhece o mesmo gesto de Miguel. Esse gesto, logo adiante, é compreendido: "e de repente descobri por que me lembrei de Miguel quando vi Diogo com o mesmo jeito de menino encabulado, o cabelo escorrendo água. Vi o céu dançarinar nas lágrimas. Então senti sua mão penetrar devagar nos meus cabelos tentando desenredá-los" (HN, p.114). No capítulo 15, Rosa anuncia que falará de seu primeiro amor e segue à apresentação de sua família, distinguindo o lado rico, representado por Miguel e os

${ }^{276}$ BEAUVOIR, Simone de. A velhice. Op.cit., p. 99. 
tios Lucinda e André, descendentes da burguesia elitista, e o lado pobre, com uma família 'desestruturada', constituída pela própria atriz e sua mãe.

Partindo do recorte de uma visita que fizera aos parentes ricos numa quinta-feira à noite, dia da semana reservado a uma canja especial na casa dos tios, Rosa revela quão surpresa ficou quando viu tia Lucinda usando uma farda e com os cabelos cortados, requisitos fundamentais para que a tia pudesse integrar o Batalhão Feminino da Defesa Passiva Antiaérea, sua 'contribuição' à pátria durante a Segunda Guerra Mundial, prestes a terminar $^{277}$. Conta-nos também os momentos que antecederam a reunião dos membros da família à mesa do jantar, com o embaraço da tia tentando manter a aparência de normalidade, e com tio André fingindo não se incomodar diante da 'displicência' de Miguel: o mesmo Miguel, rico, devasso, drogado e de cabelos molhados, dos "olhos verdes que repentinamente ficavam negros como a maçaneta das portas" ${ }^{278}$, é quem daria em Rosa o primeiro beijo, prendendo sua cabeça entre seus dedos, quando, diante da emoção e do medo, viu o céu 'dançarinar em lágrimas' nessa mesma noite, na iminência de um blecaute que ocorreria na cidade. O gesto de passar os dedos por entre os cabelos de Rosa vem carregado de significado na atualização da cena ocorrida na adolescência, feita desta vez pelo Diogo de cabelos molhados na praia, na medida em que a lembrança atravessa o tempo e tem seu sentido reforçado, pois se afasta da mera recordação no final da narrativa, a qual ganha ares de drama romântico, na tentativa de explicar quando e como se dera o primeiro beijo da atriz. A manifestação da força dessa emoção só é possível no sentido que adquire o gesto repetido anos depois, uma vez que, em Diogo, a atriz inconscientemente encontra a representação do primeiro amor, Miguel, buscado desde sempre em outros homens. Somente ao final do romance Rosa, então, revela: “(...) penso às vezes numa coisa que só tenho coragem de dizer aqui neste gravador, livre, sozinha: me agarrei em Diogo porque nele vi o Miguel? Não, não pode ser isso, necrofilia, não! (HN, p.198). O tratamento dado ao tempo ao longo do romance,

\footnotetext{
${ }^{277}$ Cabe destacar que em seu livro de fragmentos, A disciplina do amor, uma espécie de 'diário ficcional', a escritora Lygia Fagundes Telles relata que participou como voluntária, na função de 'enfermeira' daquele Batalhão de Defesa Passiva Antiaérea, como estudante 'engajada' nas causas de interesse social, durante a Segunda Guerra Mundial. É interessante notar como essa experiência possivelmente autobiográfica, recriada também no conto "Nada de Novo na Frente Ocidental", unida à imaginação, resulta em seu tão proclamado jogo ficcional de invenção e memória, como as entrevistas concedidas pela escritora e seus livros voltados para a exploração da memória individual podem comprovar.

278 Esse eufemismo, usado para revelar Miguel sob o efeito de drogas alucinógenas, evoca uma lembrança ligada aos detalhes de objetos característicos dos espaços habitados pelas protagonistas de seus romances, por exemplo- normalmente, o quarto, no ambiente doméstico. Ele pode ser encontrado, também, em Verão no Aquário, na descrição que Raíza faz de sua prima Marfa: "Ela cravou o olhar em mim. Tinha as pupilas redondas e negras, de um brilho fosco. Lembrei-me das maçanetas das portas da nossa antiga casa". In: TELLES, Lygia F. Verão no Aquário. Rio de Janeiro: Rocco, 1998, p. 15.
} 
como revela essa passagem, diferentemente do que ocorre na quase totalidade dos capítulos 15 e 16, ganha singular destaque na apresentação não-cronológica nem linear de episódios vividos pelas personagens, tal qual o mecanismo de funcionamento da própria memória, que não se alimenta do tempo cronológico mas que é, essencialmente, silêncio e som, claro e escuro, exposição e ocultamento.

A história interrompida no episódio do jantar continua no capítulo seguinte e a tarefa de ordenação da memória segue pela cena em que Rosa encontra o primo morto por overdose nos braços de tia Lucinda, um quadro quase idílico, que repercute e se projeta como a imagem da Pietá, notada por Rosa no momento da enunciação das memórias, e termina com o encontro da futura atriz com seu futuro marido, Gregório, na festa de casamento da prima Flora. Nessa ocasião, a jovem Rosa, a pedido de sua mãe, oculta do restante da família a tragédia ocorrida, para não ofuscar a felicidade da prima - segundo a própria Rosa, este foi seu primeiro papel, sua primeira grande representação: o fingimento necessário para articulação de um aparente bem-estar. Adentrando o capítulo 15, o leitor descobre, então, como viviam os pais da protagonista, a luta de sua mãe para manter 'uma aparência decente', em oposição à situação abastada da família dos tios, baseando-se na comparação entre os dois espaços privados, que oferecem por meio da caracterização externa principalmente dos elementos mais evidentes, o reconhecimento do status social ou a falta dele, marcando aí a força das imagens do belo e do abastado que Rosa perseguiria. O espaço doméstico é reconhecido, uma vez mais, como local privilegiado da reconstrução do passado e da subjetividade fragmentada, tido como refúgio num mundo em constante transformação, como é comum nas narrativas escritas por mulheres sobre personagens femininas; por essa razão, esse espaço está carregado de um valor altamente simbólico. Como afirma Gaston Bachelard, "quando se sonha com a casa natal, na extrema profundeza do devaneio, participa-se desse calor inicial, dessa matéria bem temperada do paraíso material. É nesse ambiente que vivem os seres protetores." 279

À família de Rosa pertencia um sobradinho amarelo com janelas de vidros azuis e vermelhos, através dos quais Rosa brincava de ver a rua na infância e que formavam uma moldura ao redor do vidro oval com o desenho de uma cegonha, além do portão de ferro, corrente e cadeado no porão, típico da classe média, à qual o pai da futura atriz, um funcionário público, pertencia. À moradia modesta da família de Rosa correspondia o palacete de Lucinda e André, uma casa vasta, com carro importado e motorista uniformizado,

${ }^{279}$ BACHELARD, Gaston. A poética do espaço. Op.cit., p. 27. 
jardim, salva de prata no vestíbulo, lareira, quadros e tapetes finos, empregados, em que o 'chefe de família', médico, ocupa uma posição privilegiada tanto econômica quanto socialmente. É interessante notar que a antiga casa da atriz, a da infância, só recebe tratamento memorialístico no seu aspecto exterior; já a casa de Lucinda é relembrada em detalhes, por tratar-se de objeto de desejo da futura atriz no que toca à amplitude do local, bem como elementos de valor e de reconhecimento social nela presentes. Como ruínas de um espaço descoberto como amado e valorizado somente anos depois, restam de sua pequena casa apenas as lembranças dos vitrais coloridos, que permitiam a Rosinha ver seu pobre mundo em outras cores, bem como a do tacho de cobre onde sua mãe fazia 'a melhor goiabada do mundo'.

Só é possível compreender que Rosa ascende socialmente e alcança o mesmo nível de vida dos tios e do primo, tão cobiçado, se ouvirmos, no silêncio dessas memórias por ela gravadas, os ecos espalhados por Lygia Fagundes Telles, como pistas ao longo do romance, de que isso só foi possível não apenas pelo trabalho, mas sim, graças à herança deixada para a futura atriz por outra tia, Ana. Juntamente com Lucinda, constituía o lado rico da família, o que assinava revistas nacionais e francesas que, depois de lidas, eram oferecidas à família de Rosa, com o motorista de tia Ana entregando na porta da modesta casa os pequenos pacotes amarrados com cadarços. Essa oferta consiste na representação velada de uma 'luta' pouco perceptível, camuflada pela caridade burguesa, uma forma de aplacar e disfarçar as diferenças de estilo de vida daqueles que se encontram ligados justamente por laços familiares, mantendo, assim, as aparências.

Tia Ana, a "Ana Grana", morrera sozinha, solteira e com um terço na mão ${ }^{280}$. Essas expressões carregam em si as características daquelas mulheres, normalmente de classe abastada, que, por não terem se casado, isto é, por não terem seguido 'o destino feminino', encontravam na dedicação de seu tempo e de seu dinheiro a causas nobres como a assistência aos mais necessitados, fundamentada nos princípios da caridade cristã, uma forma de combate à solidão, nem sempre bem sucedido. Segundo a descrição da protagonista, essa tia agradaria bastante a analista da atriz, Ananta Medrado, porque Ana era uma 'feminista exemplar', que morrera antes de conhecer o teor da proposta feminista, principalmente a da 'segunda onda', que se configuraria somente a partir das décadas de 60 e 70; segundo Rosa, essa é a razão que

\footnotetext{
${ }^{280}$ Aqui, há outra semelhança notória entre Verão no Aquário e As Horas Nuas. A figura pouco delineada de tia Ana, no entanto, assemelha-se à de tia Graciana, como mulheres solteiras que se ocupam de cuidados com os sobrinhos ou de trabalhos sociais. O diferencial é que a primeira é uma personagem de classe social abastada e a segunda, uma pobre mulher que depende da caridade dos parentes mais próximos até no que se refere à questão da moradia.
} 
explica o fato de as atividades dessa tia acabarem na relação de caridade. A aproximação entre duas 'feministas', distanciadas pelo tempo em que viveram, anos 80 e anos 50, respectivamente, consiste, na verdade, na crítica ao movimento programado, representado por Ananta, diversas vezes debochado e criticado por Rosa ao longo do romance, se comparado à atitude individual de uma 'grande dama da caridade' como Ana, socialmente reconhecida e conhecida. Se o feminismo de Ananta preconizava a luta pelos direitos da mulher, como o direito ao aborto, à educação sexual precoce, às creches para os filhos de mães trabalhadoras e à importância da denúncia da violência doméstica, a atitude solitária de Ana "Grana" tendia à assistência, mas também ao assistencialismo: fundou a Casa da Mãe Solteira, o Lar das Menores Abandonadas, contratava advogados para as moças 'perdidas e enganadas' pelos namorados e concedia alimentos e enxoval de bebê para as mães mais pobres, além de encaminhamento médico, no caso das doentes.

Em contraponto às figuras femininas com as quais Rosinha convivia mais de perto, é curioso notar o tratamento dado pela escritora às personagens masculinas, revelado na poética feminista de Lygia. Voltando nosso olhar para Ciranda de Pedra, é possível notar no primeiro romance da escritora que a maioria dessas personagens adota comportamentos preestabelecidos, tidos como 'apropriados' ao sexo masculino, mas vão perdendo as forças, até se transformarem em figuras apagadas, extremamente frágeis com relação à fortaleza de Virginia, a protagonista; no entanto, a partir de Verão no Aquário, As meninas e, especialmente, em As Horas Nuas, essas figuras fogem aos modelos hierarquizados, aos 'atributos de homem' (agressividade, competitividade, força, objetividade, etc.). Ao contrário, as personagens masculinas, principalmente a figura do pai, são caracterizadas por qualidades historicamente atribuídas/desejáveis à mulher: docilidade, ternura, sensibilidade, fragilidade.

Assim como Samuel, tio da protagonista Raíza em Verão no Aquário (1963), André, pai de Miguel, é símbolo da decadência da autoridade paterna, índice da fraturada família burguesa, centro do conflito entre pais e filhos. Não é gratuito o fato de que Lygia Fagundes Telles caracterize André como um médico integrante do quadro de 'doutores' do Hospital do Juqueri, famoso centro de tratamento de pessoas com distúrbios psíquico-emocionais, temido principalmente pelas mulheres. A escritora parodia a questão da loucura, normalmente considerada como 'natural' ao corpo feminino, à sua sexualidade, quando atribui à personagem André as características que, por tanto tempo, o discurso médico conferiu àquelas mulheres que apresentavam uma conduta não esperada/desejada pela sociedade repressora e centralizada na figura do pai desde o século XIX: sua dificuldade em lidar com a realidade e 
sua transcendência por meio do escapismo fazem-no ignorar a situação-limite em que o próprio filho, usuário de drogas, vivia.

Em seu estado de apatia e 'loucura', no entanto, o médico que gostava de tocar valsas ao violino transfere totalmente a responsabilidade pela educação de Miguel para Lucinda. Diante da displicência do filho, e do distanciamento dos pais, a relação familiar é atingida pela mais pura incomunicabilidade; Lucinda demonstrava estar aflita com o comportamento de Miguel no que se referia à presença de André, uma vez que da postura do filho dependia a aprovação de seu desempenho de mãe e esposa dedicada e cumpridora de seu 'papel' - como sugere o aperto no braço que recebe do esposo quando este presencia o comportamento debochado do filho na sala de jantar, local privilegiado para se vestirem as máscaras sociais. Embora presente nas refeições e como esteio econômico da família, sua figura de pai atuante é quase nula, ausente. Portanto, de Lucinda como mãe, esposa e dona-de-casa exemplar depende o sucesso de André como homem público, assim como o de toda a família, como preconizava o modelo de família burguesa.

Criando tais personagens com essas características, Lygia mais uma vez faz uso de um recurso que desmantela as tradicionais categorias de identidade baseadas nos sexos masculino e feminino, em favor de identidades de gênero, em que se aliam as questões de classe, por exemplo. Já na comparação com o pai da protagonista Raíza, de Verão no Aquário, a figura paterna de Rosa também é delineada como alguém incapaz de lidar com a realidade, sensível e sonhador como Giancarlo, contrário à representação materna, tida como sustentáculo, rocha sobre a qual a família poderia reerguer-se. Se Patrícia, mãe de Raíza, encontra na atividade literária o ganha-pão da família ${ }^{281}$, a mãe de Rosa fazia goiabada, que vendia na vizinhança, fato que levou Rosa a sentir, por anos, ódio do cheiro de goiaba, uma vez que a fruta simbolizava o tempo das vacas magras, em que o trabalho árduo era sinônimo de necessidade e motivo de vergonha para a futura atriz, símbolo da impossibilidade de imitar os padrões de consumo de seus tios.

Durante o relato em que recupera e reconstitui a memória de sua família e a de tia Lucinda, Rosa, como narradora-protagonista, conta ao gravador que via na possibilidade de casamento com o primo, por quem nutria um amor romântico e platônico, o trampolim para

\footnotetext{
${ }^{281}$ Essa visão também é compartilhada por Mabel Knust Pedra: "No universo ficcional de Lygia, observamos a recorrência da questão da desestruturação da família e do desencontro dos sujeitos nesse meio, e a emergência de uma nova configuração familiar, cujo centro, outrora ocupado pelo pai, vai agora sendo dominado pela mulher. Sob essa perspectiva, vão-se desenhar, nas tramas fabulares, a redução das personagens masculinas a papéis secundários e a consequente projeção de uma personagem feminina como protagonista da narrativa." PEDRA, Mabel Knust. O círculo de giz: a família burguesa patriarcal em Lygia Fagundes Telles. Op.cit., p.48.
} 
sua ascensão econômica e social, que seria conquistada, no entanto, por sua profissionalização:

(...) [esse casamento] que me daria segurança para seguir até a próxima etapa, os estudos. A carreira de atriz, adeus agregados! Adeus porões sombrios, ônibus sacolejantes com o dinheiro exato da passagem dentro da capanga, estavam na moda essas bolsas a tiracolo de couro cru e rudes como as peixeiras dos feirantes. (HN, p.214)

A opção de Rosa pelo teatro em detrimento do cinema, largamente assistido pela protagonista na adolescência, representa a forma encontrada pela personagem de identificação com o requinte e a modernidade, um modo de se afastar da associação com a pobreza e o provincianismo em que vivia na adolescência. Rádio e cinema feitos no Brasil eram tidos, nos anos 40 e 50, como meios de comunicação populares, cujos tipos humanos veiculados malandros, pobres, sujeitos debochados - propagavam, de acordo com a elite ligada à cultura e à educação, uma visão do Brasil marcada pela representação de subdesenvolvimento, expresso no provincianismo e no atraso sociocultural, em nada condizente com as normas de conduta da burguesia ${ }^{282}$. Para Rosa, a atividade teatral funcionaria como uma forma de sublimação ${ }^{283}$ dos seus anseios inconscientes, provavelmente os de alcançar o mesmo patamar das mulheres 'deslumbrantes', com vestidos e jóias luxuosos que ela encontrava em sua própria família, na figura de Lucinda, e nas revistas femininas, como a francesa IllustrationFormes et Couleurs, cujas informações eram traduzidas por seu pai, que prometera levá-la um dia a Paris. As revistas tidas como femininas eclodem no período evocado por essas recordações como máquina de propaganda de novos comportamentos que afetaram as massas urbanas, como modelos e imagens relativos às formas de vestir, incorporadas às maneiras de agir e de pensar, veiculando inclusive os ideais de casamento fundamentados não apenas em seus aspectos institucionais, mas sim no amor romântico. Seus pressupostos iam ao encontro

\footnotetext{
${ }^{282}$ A burguesia paulistana, por exemplo, teve uma parcela de colaboração importante na criação de um projeto de cultura em sintonia com o do modelo dos países capitalistas europeus, tido como representante do mundo desenvolvido. O Teatro Brasileiro de Comédia, o TBC, por exemplo, fundado pelo industrial Franco Zampari, esforçava-se para 'instaurar o bom gosto' teatral junto ao público brasileiro, na medida em que trazia ao país peças de autores tidos como clássicos, bem como mestres da dramaturgia moderna, como Tenessee Williams, por exemplo, autor de duas das peças com as quais As Horas Nuas mantém intertextualidade, como vimos. Cf. NAPOLITANO, Marcos. Cultura brasileira: utopia e massificação (1950-1980). 3.ed. São Paulo: Contexto, 2008, p.17-22. (Repensando a História)

283 "Processo postulado por Freud para explicar as atividades humanas sem qualquer relação aparente com a sexualidade, mas que encontrariam o seu elemento propulsor na força da pulsão sexual. Freud descreveu como atividades de sublimação principalmente a atividade artística e a investigação intelectual. Diz-se que a pulsão é sublimada na medida em que é derivada para um novo objetivo não sexual e em que visa objetos socialmente valorizados". LAPLANCHE, Jean; PONTALIS, Jean Bertrand. Vocabulário da Psicanálise. Tradução Pedro Temen. 4. ed. São Paulo: Martins Fontes, 2001, p.495.
} 
das ideias de diferença e moral sexual predominantes no período, como os papéis delimitados das mulheres no tocante às ocupações domésticas (cuidado dos filhos e do marido) e às características próprias da feminilidade, como a pureza, o instinto materno e a doçura ${ }^{284}$. As imagens femininas e masculinas e de modelos de família veiculadas em tais revistas promoviam valores de classe, raça e gênero dominantes da época (branca, de classe média, nuclear, hierárquica e com papéis bem definidos), reforçando as expectativas sociais que faziam parte da vida das mulheres, influenciando suas atitudes e escolhas. ${ }^{285}$ Para dizer com Michelle Perrot, tais revistas davam a medida da ambiguidade daquelas influências ao mesmo tempo libertadoras e alienantes. ${ }^{286}$

Rosa, assim como tantas jovens de países periféricos, na ânsia de se manter em pauta com a 'modernidade' das mulheres de países desenvolvidos como a França, que exportava seu estilo de vida difundido na moda, inclusive ditando padrões às revistas femininas brasileiras, nutria uma secreta esperança de superar a associação com a ideia de atraso que permeava sua família, ao imitar o estilo de vida propagado por aquelas edições: deixaria de morar na residência cujos porões foram alugados para a família do pobre Cido Preto, a fim de obter uma renda extra, face ao orçamento apertado, uma vez que o lucro obtido com a goiabada feita por sua mãe e vendida na vizinhança não era capaz de dar conta das despesas da mulher e da filha abandonadas pelo marido e pelo pai. A 'cidade luz' seria conhecida mais tarde, onde a atriz, já famosa, costumava passar férias depois de longas temporadas de sucesso no teatro, imitando o estilo de consumo e de vida das classes mais abastadas. Nesse sentido, trata-se, mais uma vez, de uma representação em segundo grau porque articula, na postura de Rosa, o desejo de reconhecimento das classes dominantes frente ao subdesenvolvimento característico da situação brasileira.

Em oposição à representação de Marie Ange, a jovem de comportamento sexual liberado, uma provável jovem 'leviana', com quem Miguel mantinha assíduos encontros, já

\footnotetext{
${ }^{284}$ BASSANEZI, Carla. Mulheres dos Anos Dourados. In: DEL PRIORE, Mary. (org.) História das mulheres no Brasil. 2. ed. São Paulo: Contexto, 1997, p. 608-609. A autora, nesse estudo, analisa a influência de algumas revistas femininas brasileiras da década de 50 como o Jornal das Moças, Querida, Vida Doméstica, Você e a seção para a mulher em $O$ Cruzeiro sobre a realidade das mulheres de classe média da época. Dentre os aspectos analisados, como as questões relativas ao comportamento, namoro, divórcio, educação, o que mais chama a atenção são as ideias recorrentes sobre o lugar da mulher - o lar- veiculadas por tais revistas, o que reforçava as expectativas sociais quanto à diferenciação entre as moças de família, as quais "tinham gestos contidos, respeitavam os pais, preparavam-se para o casamento, conservavam sua inocência sexual e não se deixavam levar por intimidades físicas com os rapazes" (p. 610), e as moças levianas, mal faladas, impróprias para o casamento-modelo que, por essa razão, perdiam o 'respeito social'.

${ }^{285}$ Ibid., p. 608.

${ }^{286}$ PERROT, Michelle. Os silêncios do corpo da mulher. In: MATOS, Maria Izilda S.; SOIIHET, Rachel. O corpo feminino em debate. São Paulo: Editora da UNESP, 2003, p. 23.
} 
que a experiência sexual masculina com este 'tipo de mulher' era aceita e até mesmo recomendada, Rosa constitui um modelo de 'mulher antiga' na adolescência no que tange às práticas amorosas - leia-se vocação para o casamento, com as implicações de virgindade; no entanto, o desejo de se profissionalizar para se tornar uma atriz famosa e de sucesso, na esteira do que as figuras femininas estampadas preconizavam - modernidade no vestir, tradição no que tangia à moral- coloca a protagonista na posição de 'nova mulher', na medida em que sua sobrevivência não seria garantida pela figura masculina, normalmente associada à do membro responsável pelas provisões da casa. Pelas razões expostas, Rosa, naquele período, pode ser considerada uma jovem a meio caminho de seu processo de liberação, pois mantinha um pé fincado na casa, como a necessidade de um casamento seguro com um 'bom partido', e outro na rua, pois se distancia dos ideais impostos à figura feminina de identificação exclusiva com a maternidade e com a esfera privada do lar, ao desejar atuar no mesmo espaço historicamente ocupado pela figura masculina e pelas mulheres do povo - a esfera pública, 'lugar de homem’.

Essa necessidade de definição, expressa na dificuldade de fazer escolhas, acompanha Rosa em todos os níveis de sua trajetória, revelada como uma experiência comum de grande parte das mulheres que sofrem o antagonismo do desejo de autonomia e o ideal de segurança proporcionada pela figura masculina - inclusive no que se refere ao combate à solidão. Com a morte do primo a minar todos os planos, Gregório surge como um substituto provisório, mas que não consegue ocupar o mesmo espaço que Miguel ocupara: o amor perdido do primo rico e lindo, cuja imagem foi procurada por ela, exaustivamente, em outros homens, até encontrála, como um substituto atualizado, em Diogo ${ }^{287}$. Rosa nunca atingira a plenitude amorosa: se com Miguel não houve um relacionamento efetivo, pois a virgindade da jovem era pressuposto para que ela pudesse se casar com outro, 'com tudo direitinho', como o 'devasso' primo apregoara, ela repete o mesmo esquema, mas às avessas, com outros homens, como vimos no capítulo 3: na falta do amor, trai o marido assim como ele o fizera e não revela a descoberta, mas rejeita-a como justificativa de um comportamento natural da figura masculina; ao contrário, dá o troco: coloca-se na posição de objeto de desejo, obtendo com isso glórias passageiras com diversos homens; revela-se exigente e dominadora, como

\footnotetext{
${ }^{287}$ Vera M. T. Silva também concorda com a posição ocupada por Miguel em relação ao esposo e ao amante de Rosa: “(...) [Diogo e Gregório] diferem em tudo - em idade, aparência, preparo intelectual, expressão oral, atitude e filosofia de vida. Ainda assim, têm algo em comum, que é o fato de serem ambos tentativas frustradas de substituição do Bem-Amado arquetípico, Miguel. Opondo-se e tolerando-se mutuamente, Diogo e Gregório têm uma convivência equilibrada e, novamente, o ponto de desequilíbrio desse triângulo amoroso se situa em Rosa Ambrósio." SILVA, Vera M. T. As Horas Nuas, um jogo de deciframento. In: A ficção intertextual de Lygia Fagundes Telles. Op.cit., p. 60.
} 
Amanda e Martha, atributos contrários ao ideal de feminilidade; quando ela alcança o mesmo patamar econômico de Miguel - com a herança recebida e com os lucros advindos da atividade teatral -, a mesma degradação de costumes criticada no primo passa a pautar sua vida e, posteriormente a de Cordélia, na expressão da insatisfação permanente.

Assim, o casamento e as relações familiares revelam-se como mero jogo de aparências, principalmente quando Rosa encontra anos depois, em Diogo, a imagem do primo burguês. A atriz, portanto, transforma-se no oposto da boa esposa e boa mãe de família, ideais desejados em sua juventude e aparentemente representados por Lucinda, seu primeiro espelho. Desse modo, a esfera da modernidade, associada com as ideias de riqueza e felicidade, tão almejadas na adolescência e normalmente ligadas à representação masculina, apresenta-se para Rosona, em franca decadência profissional, como fim de um sonho. Diante da nova realidade, imposta pela velhice, é como se a protagonista fizesse um balanço negativo de sua penetração no 'mundo dos homens': com a impossibilidade de continuar a ser associada à grande estrela de teatro, ao mundo do trabalho e das relações sociais, Rosa 'voltase para a esfera do lar', refletindo ao longo do romance sobre os papéis por ela relegados ao segundo plano, como vimos anteriormente. Nessas memórias, portanto, Rosona revela-se, no espelho do texto, como a desconstrução de Rosinha, a mulher que subverteu os laços do matrimônio, expresso no ideal da própria felicidade condicionada à satisfação do esposo e ao exercício da maternidade como obrigação social, em favor dos desejos próprios, e o sofrimento provocado por sua ruptura radical. A atriz, na verdade, reclama a ausência de equilíbrio entre a esfera do mundo público e a do mundo privado por ela ocupado: "Ah! se a gente pudesse se organizar com o equilíbrio das estrelas tão exatas nas suas constelações. Mas parece que a graça está na meia-luz. Na ambiguidade.” (HN, p.13)

Desse modo, as recordações do ser amado e da família, construídas por Rosa no exercício da rememoração, suscitam a recuperação do próprio eu a partir das relações construídas e refletidas no outro, encenando para o leitor os mecanismos de representação presentes nessas memórias, que veremos em seguida.

\subsection{Memória e representação}

As diferentes perspectivas históricas e/ou feministas têm importante papel no que tange ao novo valor conferido à noção de experiência, com o interesse sistemático em favor 
de novos sujeitos, o que permitiu a reavaliação das narrativas pessoais ou de vida, tais como jornais, cartas, diários, confissões, auto-retratos, autobiografias, biografias. A 'morte do sujeito', a crise da ideia de subjetividade, tão apregoada pela onda estruturalista e pósestruturalista dos anos 1970, cedeu lugar ao que Beatriz Sarlo denominou "guinada subjetiva", a partir do momento em que o campo dos estudos relacionados com a memória passou a se dedicar à 'ressuscitação' daqueles sujeitos ${ }^{288}$. A própria noção de literatura de testemunho colaborou para isso, na medida em desconstruiu a ideia de historicismo clássico ao incorporar, além de elementos tradicionalmente utilizados na ficção, como a primeira pessoa do relato e o discurso indireto livre, um olhar sobre o passado associado também às camadas marginalizadas da sociedade. Conforme explicita Marcio Seligmann-Silva,

É a partir (...) [da Segunda Guerra Mundial] que o discurso da memória (...) vai moldar a produção de importante filão das artes, a tal ponto que nas últimas décadas há quase que uma onipresença dos discursos da memória na cena artística internacional. Essa tendência foi agudizada pelos movimentos anticolonialistas, pela emancipação das mulheres e das minorias. A necessidade de recosturar as identidades antes oprimidas, e impedidas de se manifestar, ao lado do próprio movimento de luto pela perda de vidas gerada pela Grande Guerra, pelos movimentos de auto-afirmação das minorias e pelas lutas contra governos totalitários e autoritários, gerou o que chamamos hoje de uma cultura da memória. Mas não podemos esquecer que essa cultura da memória nasce da resistência ao esquecimento 'oficial' e a uma 'cultura da amnésia', do apagamento do passado, que caracteriza nossa sociedade globalizada pós-industrial. ${ }^{289}$

Na história que agora valoriza a vida cotidiana e os já mencionados discursos da memória, as mulheres, como especialistas na dimensão do público e do privado, constituem uma parcela significativa desse quadro ${ }^{290}$. O 'repensar' feminista sobre a validade da separação entre história pública e história privada coincide, segundo Linda Hutcheon, com "a renegociação geral tanto do contexto da narrativa histórica, quanto da política de representação e auto-representação" ${ }^{291}$. Tal renegociação passa necessariamente pelos novos modos de representação do passado, pela desconfiança quanto à existência de categorias

\footnotetext{
${ }^{288}$ SARLO, Beatriz. Tempo passado: cultura da memória e guinada subjetiva. Tradução Rosa Freire d'Aguiar. São Paulo: Companhia das Letras/Belo Horizonte: UFMG, 2007, p. 30.

${ }^{289}$ SELIGMANN-SILVA, Márcio. A língua como leito da memória cultural e meio de diálogo entre as culturas. In: MIRANDA, Danilo S. (org.) Memória e Cultura- a importância da memória na formação cultural humana. São Paulo: Edições SESC SP, 2007, p. 75.

${ }^{290}$ SARLO, Beatriz. Tempo passado. Op.cit., p.17.

${ }^{291}$ HUTCHEON, Linda. A incredulidade a respeito das metanarrativas: articulando pós-modernismo e feminismos. Tradução Margareth Rago. In: Labrys - Estudos Feministas, n. 1-2, jul.-dez. 2002. Disponível em < http://e-groups.unb.br/ih/his/gefem/labrys1_2/linda1.html> Acesso em: 25 jun. 2008.
} 
universais, calcadas em preceitos iluministas, base da historiografia tradicional, como os de progresso e de ascensão linear da história, para uma abertura para o registro da memória, que, por sua vez, é fragmentário, e marcado pela dialética do particular e do universal ${ }^{292}$. Joan Scott esclarece que a documentação da realidade histórica das mulheres, sua inclusão como objetos ou sujeitos da História levou as mulheres a um inevitável confronto com o dilema da diferença, o que contribuiu para o discurso de uma identidade coletiva que tornou possível, por exemplo, o movimento das mulheres nos anos 70. Segundo Scott, tal discurso foi responsável pela produção de uma experiência feminina compartilhada que enfatizava a sexualidade e as necessidades e interesses a ela vinculados. O aumento da 'consciência' permitiu a descoberta da 'verdadeira' identidade das mulheres, isto é, a obtenção da autonomia, da individualidade e da emancipação, confirmando "a realidade da categoria 'mulheres', sua existência anterior ao movimento contemporâneo, suas necessidades inerentes, seus interesses e suas características, dando-lhe uma história"293. De acordo com essas considerações, não se trata, portanto, de aceitar tacitamente a relação experiência/identidade nos estudos que envolvem a questão do gênero na análise das personagens femininas em literatura, como é o caso de As Horas Nuas, mas, sim, de um modo de contemplar aspectos da experiência comum de subordinação da mulher, de subverter representações subalternas ou verificar novas posições da figura feminina na literatura em prol da autorrepresentação e de promover um trabalho crítico de interpretação feminista, considerando-se aí o papel da leitora de textos literários escritos por mulheres, adequando tais aspectos à multiplicidade da própria categoria 'mulher', distante de quaisquer concepções essencialistas ou apenas ontológicas. Trata-se, portanto, de descobrir, na leitura da ficção escrita por mulheres, "um discurso de duas vozes" que contém tanto uma "história dominante" quanto uma "silenciada." 294

Philippe Lejeune, em O pacto autobiográfico, fornece algumas categorias de análise que colaboram para a diferenciação de textos que caracterizam o que se pode chamar de "literatura íntima" ou "escritas do eu"/ "escritas de si", como diários, cartas, autobiografias e biografias. $\mathrm{O}$ autor estabelece quatro categorias cujos elementos participam da definição de

\footnotetext{
${ }^{292}$ SELIGMANN-SILVA, Márcio. Reflexões sobre a memória, a história e o esquecimento. In: (org.). História, Memória, Literatura- O Testemunho na Era das Catástrofes. Campinas: Editora UNICAMP, 2003, p. 60-65.

${ }^{293}$ SCOTT, Joan. História das mulheres. In: BURKE, Peter (org.). A escrita da história: novas perspectivas. Tradução Magda Lopes. São Paulo: Editora UNESP, 1992, p. 83-84.

${ }^{294}$ SHOWALTER, Elaine. A crítica feminista no território selvagem. In: HOLLANDA, Heloísa B. (org.) Tendências e impasses. Op.cit., p. 53.
} 
autobiografia, a saber: "narrativa retrospectiva em prosa que uma pessoa real faz de sua própria existência, quando focaliza sua história individual, em particular a história de sua personalidade". Tais categorias consistiriam na forma da linguagem (narrativa e em prosa); no assunto tratado (vida individual, história de uma personalidade); na situação do autor (identidade do autor e do narrador) e na posição do narrador (identidade do narrador e do personagem principal, e perspectiva retrospectiva da narrativa). Neste caso, o nome próprio é o aspecto que fundamenta a produção da autobiografia, isto é, a relação de identidade entre o autor, o narrador e o personagem, o que Lejeune denomina pacto autobiográfico ${ }^{295}$. As memórias, assim como outros textos da literatura íntima, diferenciam-se da concepção da vizinha autobiografia por não preencherem algumas daquelas categorias que, no caso das primeiras, foge à do assunto tratado: vida individual, história de uma personalidade. ${ }^{296}$

Anos depois, em O Pacto Autobiográfico (Bis), o crítico francês chama atenção para a definição por ele mesmo proposta de autobiografia. Comparando-a com as constantes nos dicionários elaborados por Larousse e Vapereau, citadas pelo próprio Lejeune, é interessante notar o contraponto com a 'definição de memórias' corrente nos dicionários, isto é, a de um relato escrito que alguém faz de acontecimentos históricos vividos por si mesmo ou sobre sua própria vida. Segundo Lejeune, Larrousse opõe a autobiografia (vida de um indivíduo escrita por ele mesmo), que é uma espécie de confissão, às memórias, as quais contam fatos que podem ou não ser alheios ao narrador; já Vapereau afirma que "a autobiografia abre um grande espaço à fantasia e quem a escreve não é absolutamente obrigado a ser exato quanto aos fatos, como nas Memórias, ou a dizer toda a verdade, como nas confissões."297

Com base nessas considerações, é possível verificar que o desejo de Rosa Ambrósio de escrever suas memórias revela a dupla função que seu livro teria: dar sentido à experiência vivida no presente, na tentativa de apagar as lembranças ruins, mas também reforçar a ideia narcisista da adulação e da inveja que provocaria diante de sua volta triunfante, após quatro anos, aos palcos teatrais e à mídia: “(...) Vou trabalhar, o palco, adoro o palco com os invejosos mordendo o rabo feito escorpião, bem feito! Escrevo essa bosta de livro, memórias deslumbrantes, não o avesso mas só o direito das coisas, uma winner! (...)” (HN, p.46). A 'paixão pelo nome próprio' também integra um projeto amplo de resgatar a 'dignidade' da

\footnotetext{
${ }^{295}$ LEJEUNE, Philippe. O pacto autobiográfico. In: LEJEUNE, Philippe; NORONHA, Jovita M. G. (org.) $O$ pacto autobiográfico- de Rousseau a Internet. Tradução Jovita M. G. Noronha, Maria Inês Coimbra Guedes. Belo Horizonte: Editora UFMG, 2008, p. 26.

296 Ibid., p. 14.

297 Apud LEJEUNE, Philippe. O pacto autobiográfico (bis). In: LEJEUNE, Philippe; NORONHA, Jovita M. G. (org.) O pacto autobiográfico. Op.cit., p. 53-54.
} 
atriz, expresso num hipotético retorno triunfal ao teatro como vencedora, com seu público de gosto erudito, seguido da publicação de seu livro para uma possível conquista de outro público, o das massas populares. Disso decorre o tom irônico utilizado por Rosa no que se referia à escrita das memórias:

(...) Fui convidada, aceito, a peça é de Sartre, Reaparecimento de Rosa Ambrósio! Sucesso absoluto, coisa deslumbrante, a salvação pelo trabalho. Em seguida, as minhas memórias, tudo quanto é perna-de-pau já escreveu as suas, por que não eu? Hem?!...As Horas Nuas, você aprovou o título, também eu nua sem tremor e sem temor. (HN, p.42-43)

Com o afastamento gradativo de Rosa dos palcos, a escrita dessas memórias consistiria num esforço de obter novamente visibilidade, mas sua inconclusão remete à impossibilidade mesma de integrar esse mercado, expresso na descrença da personagem nas 'escritas de si', uma vez que, como uma artista de classe, ironicamente, não consegue igualarse aos 'pernas-de-pau' que escreveram suas próprias memórias. No campo da cultura, a década de 80 , que oferece as condições de produção e publicação de As Horas Nuas, consistiu em um momento propício ao crescimento, já observado na década de 70 , no número de relatos memorialistas, autobiografias e confissões, trajetórias de vida e publicação de documentos que despontaram como um modo de levantar o substrato do vivido, mas também como procedimentos de denúncia e testemunho, no campo político e cultural, das atrocidades do regime imposto, um esforço de resgatar/contar/interpretar um passado repleto de momentos obscuros. Esse momento específico da história e das artes no Brasil corresponde, num plano global, a um período que remete à preocupação de preservação da memória em geral, expressa em um profundo desejo de documentar e registrar sem a garantia, no entanto, de "produzir consciência histórica", de "aumentar a capacidade de perceber as transformações da sociedade pela ação humana, permitindo que se tenha (...) a experiência dinâmica social, da ação das forças que constroem a sociedade e que podem mudá-la a todo instante" ${ }^{298}$. Wander Mello Miranda corrobora essa posição, afirmando que a produção de relatos memorialistas, gênero tão em voga no mercado editorial brasileiro da década de 80 , revela-se "mera repetição de modelos e procedimentos literários desatualizados ou estereotipados”, com exceção de $O$ que é isso, companheiro?, e que a

\footnotetext{
${ }^{298}$ MENESES, Ulpiano B. Os paradoxos da memória. In: MIRANDA, Danilo S. (org). Memória e Cultura- a importância da memória na formação cultural humana. São Paulo: Edições SESC SP, 2007, p. 21.
} 
(...) a força questionadora da tarefa de repensar a história brasileira através do relato da experiência pessoal vivida deixa-se enfraquecer a favor de uma atitude imediatista no tocante à produção textual e consumista no que se refere à sua recepção, processo alimentado incessante e interessadamente pelo aparato capitalista, oportunista e voraz, do mercado editorial. ${ }^{299}$

Ao travar um diálogo com esses subgêneros, portanto, a autora implícita revela, em Rosa, na verdade, a preocupação em distanciar-se da literatura feita para massas, com uma evidente distinção da literatura tida como arte, visão que se alimenta dos resquícios da hierarquia cultural e dos padrões de gosto vigentes até o final da década de $70^{300}$, intimamente ligada ao projeto estético e ideológico modernista de construção da identidade nacional a partir de um denominador cultural comum capaz de integrar as diversas classes sociais, para vencer o provincianismo e o arcaísmo que caracterizava o país. A posição de Rosa Ambrósio como narradora e como personagem revela a intenção paródica ${ }^{301}$ da autora do romance no trabalho de produção das memórias como gênero, pois "ao mesmo tempo em que critica um gênero, apropria-se dele para construir seu enredo"302. Desse modo, confirma a descrença no gênero autobiográfico ${ }^{303}$, revelada na forte ironia que permeia essas memórias. Essa ideia já é bem delineada no primeiro capítulo do romance, quando Rosa, caída por sobre uma trouxa de roupas sujas, completamente embriagada, recorda-se do jovem Douglas, dono de um jornal

${ }^{299}$ MIRANDA, Wander Mello. Corpos escritos- Graciliano Ramos e Silviano Santiago. São Paulo: EdUSP, 1992, p. 19.

${ }^{300}$ Marcos Napolitano afirma que a mudança da estrutura de consumo cultural e dos padrões de gosto foI responsável por colocar em xeque as hierarquias culturais, a postura adotada por uma sociedade diante de uma determinada obra, que se dá pela articulação entre a preferência dos consumidores de renda e escolaridades mais elevadas, a qualidade da obra e o reconhecimento social do valor do artista. A partir desses critérios, "a burguesia letrada e a classe média intelectualizada davam o tom da vida cultural brasileira, impondo seus padrões de consumo cultural como medidas de valor", ao fixar ou excluir do cânone as obras com os atributos de bom ou ruim. Com a presença da indústria cultural como espaço estruturante da vida cultural, passaram a existir mais grupos de consumidores sociais, oferecendo uma maior pluralidade de padrões de avaliação cultural e estética. NAPOLITANO, Marcos. Cultura. In: PINSKY, Jaime (org.) O Brasil no contexto: 1987-2007. 2. ed. São Paulo: Contexto, 2007, p. 145-146.

${ }^{301}$ Esse também é o argumento de Carlos Magno Gomes. Assim como faço nesta tese, em seu artigo, o autor também faz uma leitura das memórias gravadas como texto espelho da narrativa; no entanto, sua concepção funda-se na ideia de paródia como escrita teatral, no sentido de performance pós-moderna, direção oposta ao que pressuponho neste trabalho. GOMES, Carlos M. A paródia da autobiografia em Lygia Fagundes Telles. In: Acta Scientiarum Language and Culture. Maringá, v. 30, n. 1, p. 79-84, 2008. Disponível em: $<$ http://www.periodicos.uem.br/ojs/index.php/ActaSciLangCult/article/viewFile/4058/2902> Acesso em: 10 out. 2008.

${ }^{302}$ Ibid., p. 81.

${ }^{303} \mathrm{Em}$ A disciplina do amor, livro de fragmentos, à guisa de diário, a presença de elementos supostamente pertencentes à memória de Lygia fornecem o substrato para uma escrita puramente ficcional, distanciando-se, de certo modo, de sua caracterização como texto autobiográfico. Essa relação de ficcionalização de eventos e fragmentos do passado em textos propriamente literários pode ser confrontada em diversas entrevistas concedidas por Lygia Fagundes Telles, nas quais reafirma a posição de que, se escrevesse um diário, inventaria todo o seu conteúdo. 
que se referia ao nome da atriz com "palavras maravilhosas": “(...) me via nele como num espelho. Posso começar assim as minhas memórias: Quando nos olhávamos eu via minha beleza refletida nos seus olhos" (HN, p.10). Apesar de amar o espetáculo, o palco, a vida pública, Rosa Ambrósio encontra refúgio na negação da visibilidade de seu envelhecimento, justamente numa época de espetacularização da intimidade. Isso explica por que o ambíguo desejo da atriz de voltar à cena pública com o lançamento de suas memórias não se realiza e apresenta a contrapartida de ter suas relativas verdades reveladas justamente nos momentos marcados pela mais pura solidão, sem nenhuma testemunha dos fatos vividos. ${ }^{304}$

As memórias, que funcionam como espelho narcísico onde Rosa Ambrósio pode projetar lembranças e situações que ajudam a construir uma imagem de si mesma, também funcionam, em termos de metanarratividade, como o texto espelho criado por Lygia com uma função invertida: é ele que permite ao leitor, juntamente com as observações de Rahul e Ananta, verificar a validade das memórias outrora reveladas nos capítulos anteriores, na medida em que, na prosa ambígua da escritora, desmantela também outras representações da figura feminina e de família que auxiliam no processo de desnudamento às avessas da protagonista. Isso se dá porque a memória, com a função de criar significados, está intimamente ligada à imaginação, "uma forma de ampliar a experiência do homem além da sua própria experiência individual" 305 . É nesse sentido que a imaginação entra em cena não só no que se refere à produção do discurso da memória, no tocante à elaboração da narração de um passado tornado presente pelas condições mesmas desse presente, mas também, na possibilidade de o leitor desse discurso permitir-se um distanciamento dessa "presentificação da experiência" para tornar possível a trilha por outros caminhos de leitura que recuperem, com base em outros dados, aquilo que possivelmente ficou de fora de tal narração.

Se Rosa pretende estabelecer um pacto de leitura de suas memórias com um pretenso leitor, na acepção de Lejeune isso é possível se, "ao fazer um acordo com o narratário cuja imagem constrói, o autobiógrafo incitar o leitor real a entrar no jogo dando a impressão de um

\footnotetext{
${ }^{304}$ Sobre esse aspecto, Suênio C. de Lucena apresenta uma perspectiva complementar: “(...) a atriz-narradora resolve ditar suas memórias no momento em que teme perder valores, entes queridos e em ser esquecida para sempre. Essa decisão parece ser uma reação às perdas, mas que adiante se revelará falha. (...) O livro reitera uma memória como tentativa (e fracasso) de manutenção de sujeitos, espaços, hábitos e costumes". LUCENA, Suênio C. Esquecimento e lembrança em Lygia Fagundes Telles. Op.cit., p. 128-129.

${ }^{305}$ MENESES, Ulpiano Bezerra de. Os paradoxos da memória. In: MIRANDA, Danilo S. (org). Memória e Cultura. Op. cit., p. 17-18. Esta questão também é discutida por Sarlo, a partir da visão de Hannah Arendt, no que tange ao papel da imaginação no trabalho de exteriorização e distância do crítico e do ouvinte em relação ao testemunho.
} 
acordo assinado pelas duas partes" ${ }^{306}$. No caso de pessoas que viveram e/ou presenciaram situações-limite - como foi o caso do Holocausto e mesmo de vítimas dos regimes autoritários impostos na América Latina nas décadas de 1960 e 1970 -, o estatuto de verdade de seus testemunhos é valorizado e remete a uma necessidade jurídica, moral e política, principalmente quando são utilizados, em condições judiciárias, como modos de estabelecer os elos para transições democráticas ${ }^{307}$. Em condições não judiciárias, essas mesmas prerrogativas, no entanto, não se aplicam a outras narrações em primeira pessoa, nas quais se misturam "os argumentos de sua verdade, suas legítimas pretensões de credibilidade e sua unicidade, sustentada na unicidade do sujeito que o enuncia com a própria voz, pondo-se como garantia presente do que diz, mesmo quando não se trata de um sujeito que suportou situações-limite" ${ }^{308}$. Com isso, tais memórias correm o risco de serem submetidas à crítica, na medida em que o leitor pode adotar modos de leitura diferentes, uma vez que muitos textos publicados não comportam nenhum contrato explícito. Isso fica ainda mais evidente no caso de As Horas Nuas porque o processo de produção das memórias não é realizado por uma pessoa real, mas sim, por uma personagem fictícia, por trás da qual a autora implícita encontra-se colada, mantendo-a sob seu controle.

O exercício da palavra a partir do qual Rosa elabora seus questionamentos na ausência de Ananta e de outras 'testemunhas' confirma a ideia de que somente sozinha seja capaz de falar sobre o passado sem medo, embora as máscaras permaneçam. Por isso, os comentários sobre a morte de Gregório, o adeus de Diogo e o desaparecimento de Ananta surgem imediatamente antes da gravação propriamente dita, no início dos capítulos já mencionados, pois assim se estabelece, com o conteúdo gravado em seguida, a dialética da exposição e ocultamento, revelada para o leitor do romance, mas não para o suposto leitor do livro de memórias As Horas Nuas. A ausência-presença dessas três personagens se alinha pelas condições que ofereceram justamente para que a matéria narrada ao gravador se constituísse em um "depoimento-virgem" (HN, p. 200): graças à falta de Ananta, Rosa consegue se levantar e realizar o depoimento; graças a Gregório, que "já sabia que a traição faz parte do amor" (HN, p.200); e graças à libertação dessas muletas e culpas, encontra-se renovada para recomeçar sua relação com Diogo e, quem sabe, retomar, fortalecida pela presença do amor, a carreira profissional.

\footnotetext{
${ }^{306}$ LEJEUNE, Philippe. O pacto autobiográfico (Bis). In: LEJEUNE, Philippe; NORONHA, Jovita M. G. (org.) O pacto autobiográfico. Op.cit., p.57.

${ }^{307}$ SARLO, Beatriz. Tempo passado. Op.cit., p. 47.

308 Ibid., p. 37.
} 
No que se refere ao processo de produção das memórias da protagonista de As Horas Nuas, pode-se dizer que, embora obedeça a uma rigorosa cronologia dos fatos ocorridos e mantenha o princípio de causalidade da narrativa, com a articulação espaço-temporal bem definida, a gravação das memórias é interrompida, por vezes, por uma espécie de recuo, quando a protagonista, totalmente consciente do processo de sua produção, questiona a eficácia do aparelho, duvidando se ele ainda está gravando seu discurso ou não; ou parece não suportar a força das lembranças e recorre a um gole de uísque; ou ainda, quando atualiza a dor da perda de Miguel, marcando o texto com uma autorreferenciação, diminuindo a distância que separa o tempo do enunciado do tempo da enunciação, a Rosa personagem da atriz narradora: "Foi duro, Rosa Ambrósio. Foi duríssimo e a dureza não ficou aí (...)" (HN, p.221). Rosa repete essas mesmas atitudes ao longo do romance, pois instaura a dúvida diante do que enuncia, assim como Rahul - verdade ou invenção? - e, quando não suporta a culpa, diante de uma revelação prestes a acontecer, muda de assunto, 'baixa o pano', reclama de cansaço ou interrompe o jorrar do pensamento com a frase "Enfim, não interessa". Embora procure fingir que o fato não tem a menor importância e mude de assunto, o que ela faz é mostrar ao leitor sua incapacidade de reduzir as lacunas entre passado e presente. Como não supera o medo, enche o copo e a 'cara'.

Dentre esses índices de representação, há, porém, um que revela o alto grau de teatralização que envolve a produção das memórias que não saem por escrito e nem se efetivam como tal. Trata-se da passagem em que a atriz se aproxima do gravador e afirma que falará do primeiro amor, independentemente do que possa parecer, pois o que

(...) interessa é a palavra testemunhando este instante, captando o fluido que vem aqui de dentro na minha voz bem timbrada, estou serena. A pronúncia caprichada, nenhum né? e nenhum tá! porque sou uma atriz e uma atriz de classe deve falar bem. Com a altivez de quem interpretou Shakespeare e se prepara para voltar ao palco. Eu vou voltar. (HN, p. 200)

As marcas dessa encenação da 'nova Rosa Ambrósio' ficam ainda mais evidentes quando ela afirma o desejo de que a palavra testemunhe aquele instante captando o fluido de sua voz bem timbrada. Esse fluido, no entanto, entendido como a matéria que naturalmente emergia de sua consciência, como nos capítulos anteriores, recebe aqui um tratamento rigoroso de seleção e censura; afinal, imediatamente antes de se aproximar do gravador, ela garante que as traições foram muitas, mas "não interessa": o essencial é estar vivo, pois "sem 
morte e podridão o amor não poderia ressuscitar" ${ }^{309}$. Com isso, Rosa revela que essa palavra não é capaz de captar sua 'natureza mais profunda', a qual Rahul, ironicamente, diz não saber onde se encontra. Por outro lado, a personagem contradiz o uso de uma expressão 'caprichada', traindo-se, pouco tempo depois de afirmar que uma atriz de classe como ela 'deve falar bem', ao utilizar um vocabulário carregado de expressões típicas da oralidade e também termos de baixo calão, o que não nega sua origem pobre e humilde: "o romântico paizinho pirado que foi comprar cigarros lá no cu-do-judas e até hoje, hem?!” (HN, p.201grifo meu). Além disso, essa escolha lexical também é indício de mais um campo permitido histórica e socialmente aos homens, mas que fora penetrado por Rosa e por outras protagonistas femininas de Telles, frequentemente tido como inadequado para a figura feminina, cujos lábios deveriam declamar apenas orações e castas poesias. ${ }^{310}$

Em um dado momento de seu delírio alcoólico, Rosa diverte-se com a lembrança do que Diogo lhe dissera: ela vestiria suas “(...) horas peladas uma por uma, calcinhas, cílios postiços, echarpes. Você é uma narcisista, Rosona. E os narcisistas são barrocos" (HN, p.55). Narcisista e barroca: a própria representação embaçada, a encenação descoberta, o que explica por que Diogo insistia em classificá-la com o referido adjetivo. O ex-secretário/amante tinha plena consciência das excentricidades e extravagâncias de Rosa e sabia que suas memórias sairiam revestidas por máscaras e fantasias, mostrando apenas o 'lado direito das coisas', o que pode ser entendido como um processo de produção das memórias com uma valorização da linguagem como criação de um real, que pode ou não coincidir com a 'verdade', a partir da rica exploração do mundo imaginário ${ }^{311}$. Isto se dá em perfeita sintonia com a profissão da

\footnotetext{
${ }^{309}$ Essa ideia de morte e ressurreição é frequente na ficção de Lygia, especialmente em seus romances. Normalmente, a frase está ligada a um processo de metamorfose das protagonistas que ocorre no final do texto, anunciando uma nova etapa a ser iniciada. Essa ideia de ressurreição se expressa no final em aberto de Ciranda de Pedra e Verão no Aquário, os quais não apresentam uma resposta clara ou conclusiva sobre o destino das personagens. Pode-se dizer que, nestes dois romances, esse final em aberto constitua uma estratégia feminista da autora que, deixando de traçar os caminhos percorridos por suas protagonistas, parece sugerir diversas possibilidades de futuro para elas. Assim, no ponto de contato da ficção com a matéria histórica, as protagonistas Virgínia e Raíza aludem à condição feminina do período de publicação dos referidos romances, a saber, 1954 e 1963, respectivamente. Veremos, adiante, que essa ideia de ressurreição, embora mantenha parte dessa concepção original, ganha outra conotação no romance em questão.

${ }^{310}$ Luisiana, do conto "Apenas um saxofone", por exemplo, recebera a 'condenação' de um de seus amantes de que "palavrão em boca de mulher é como lesma em corola de rosa" - tão repugnante a ponto de atingir sua beleza feminina, tida como meramente 'decorativa'. Além disso, essa linguagem utilizada por Rosa nas memórias contrasta com a expressão cuidadosa que a personagem tinha ao evitar determinados termos, como fofoca, ou a se referir a 'teoremas' em substituição à expressão 'problemas'. Em ambos as situações, nota-se, segundo Rahul, a influência de Gregório.

${ }^{311}$ Cabe ressaltar que, em entrevista à revista Cult, Lygia Fagundes Telles utilizou o termo barroco para caracterizar os contos que publicaria posteriormente sob o título de Invenção e Memória, uma espécie de "memória fantasiosa, depoimento real e barroco, mistura de realidade e sonho". In: LUCAS, Fábio; PINTO, Manuel da Costa. Entrevista com Lygia Fagundes telles. Cult - Revista Brasileira de Literatura, Op.cit., p. 11.
} 
protagonista: a de atriz, cuja ocupação é representar, embora os limites entre viver e atuar já estivessem bastante confundidos: "A gente devia voltar a usar luvas, tão misteriosas as luvas. Luvas e máscaras. A máscara da serenidade, a máscara da alegria, a do desprezo e da indiferença, era só escolher, hoje vou usar esta" (HN, p. 53-54). O processo de se ocultar por trás dessas máscaras não é mais algo externo à protagonista, mas característica essencialmente sua, parte dela, como vimos anteriormente.

Na própria linguagem, encontram-se novamente as marcas da ambiguidade do termo 'representação' nesta prosa de Telles, que tem um papel importante na economia do livro. A atriz alcoólatra dá início ao projeto da escrita das memórias a partir da narração do "começo do começo”, “(...) quando a Rosa em botão ia colhendo estabanadamente as rosas da manhã (...)" (HN, p.201), isto é, quando a adolescente Rosinha, como era chamada pela família, dava os primeiros passos para a construção de um futuro repleto de sonhos ambiciosos. Para tanto, seria necessário ir pela ordem - daí a importância da cronologia -, mas ela trai seu projeto logo em seguida, quando contradiz o estado de euforia e de coragem aparente, permitindo que a metáfora da colhedora da manhã do Soneto a Helena ${ }^{312}$, de Pierre de Ronsard, revele muito mais uma Rosa que perdera, ao longo da vida, o viço, o brilho, a graça, com as flores de seu buquê murchando não só com o inevitável envelhecimento, mas principalmente diante dos imprevistos e sustos. O conselho do poeta surge diretamente associado à ideia do Carpe Diem de Gregório, remetendo à ligação entre a efemeridade da rosa e o passar do tempo, da beleza e da tenra idade, opondo-se ambiguamente ao caráter de eternidade que 'as escritas do eu' pretendem marcar. Posteriormente, a atriz, que desdobrada em narradora mantinha a ilusão de onisciência e, com isso, o domínio e a objetividade do narrado, percebe a traição e recua diante do leitor hipotético de suas memórias: “(...) agora estou brincando, brincadeira minha, longe de mim qualquer traço de amargor, a última coisa que desejo é virar uma esponja de fel.

Nossa visão da linguagem como produtora do real em As Horas Nuas, aqui apenas esboçada, coincide com o ponto de vista de Nízia Villaça que, aliás, faz um breve comentário ao romance que estamos analisando, valorizando nele um olhar barroco como efeito da apregoada 'crise da representação', que se expande no contemporâneo. In: VILLAÇA, Nízia. O olhar Barroco. Paradoxos do pós-moderno: sujeito \& ficção. Op.cit., p. 126.

312 “Quando fores bem velha, à noite, à luz da vela/ Junto ao fogo do lar, dobando o fio e fiando,/ Dirás, ao recitar meus versos e pasmando:/Ronsard me celebrou no tempo em que fui bela./ $E$ entre as servas então não há de haver aquela/Que, já sob o labor do dia dormitando,/Ao nome de Ronsard não vá logo acordando/E abençoando o esplendor que o teu nome revela./Sob a terra eu irei, fantasma silencioso,/Entre as sombras sem fim procurando repouso:/E em tua casa irás, velhinha combalida,/Chorando o meu amor e o teu cruel desdém./Vive sem esperar pelo dia que vem;/Colhe hoje, desde já, colhe as rosas da vida." Ronsard, Pierre. Soneto a Helena. In: MAGALHÃES JÚNIOR, R. O livro de Ouro da Poesia da França - Antologia de Poetas Franceses (Do século XV ao século XX). Tradução Guilherme de Almeida. Rio de Janeiro: Ediouro, s/d, p.282. 
Pingando aquele fel de ressentimento, horror! quero verter bom humor. Lucidez. (...)" (HN, p. 201)

Segundo a protagonista, “onde está o tempo, está o drama", e a tarefa de recordar transforma-se em um modo de atar a juventude e a "idade da madureza" no presente. O desejo de escrever só o 'lado direito das coisas', repleto de clareza de ideias, figura como uma tentativa de explicar-se a si mesma, de modo a revelar a origem de seu drama pessoal, embora o processo de desnudamento tenha ocorrido ao longo de todo o romance e ficado evidente no momento em que reencontra a Praça da República. Isso permite também interpretar a relevância do esquecimento na configuração dessas memórias e o detalhamento que a personagem Miguel alcança nos últimos capítulos, a partir da ambiguidade dessa mesma linguagem: ele é parte do que representa 'o lado direito das coisas' para Rosa, numa época em que ela vivera seu amor platônico pelo primo e 'representava' uma menina tola apenas para disfarçar seu embaraço diante das discussões de seus pais na hora da refeição ou do comportamento indisciplinado de Miguel frente ao requinte de tia Lucinda e tio André; mas o primo é também o 'menino' rico, inconsequente, que morrera jovem, em virtude das 'más companhias', do dinheiro em demasia, das facilidades e do uso indiscriminado de drogas alucinógenas, como a mãe de Rosa procurou explicar à filha no dia do casamento da prima Flora.

Desse modo, passado e presente para Rosa Ambrósio estão ligados pela figura de um jovem já morto- no caso, Miguel-, assim como ocorre no filme cujo título também nomeia o romance de Telles. Le ore nude ${ }^{313}$ é um filme italiano da década de 60 que, por sua vez, foi baseado em um conto do escritor italiano Alberto Moravia, intitulado "Appuntamento al mare", traduzido para o português como "Encontro na praia"314. A estrutura do filme repousa

\footnotetext{
${ }^{313}$ Le ore nude. Direção: Marco Vicario. Produção: Marco Vicario. Distribuidora: Atlantica Compahia Cinematográfica. Intérpretes: Rossana Podestà, Keir Dullea, Philipe Leroy, Antonio Reis, Otello Taglietti, Gabriele Basili, Tina Lepri, Maurizio Conti, Bruno Scipioni, Umberto Spadaro. Roteiro: Marco Vicario, Alberto Moravia, Tonino Guerra. Itália, 1964, 92’. Apesar das inúmeras tentativas, não foi possível encontrar o filme. Baseei-me, para a análise, em resenhas publicadas no período em que Le ore nude foi lançado, bem como em verbetes sobre o filme, disponíveis em dicionários de cinema.

${ }^{314}$ MORAVIA, Alberto. Encontro na praia. In: O autómato. Tradução Manuel Martins de Sá. [S.I]: Publicações Europa-América, 1972 (Livros de Bolso Europa-América, 40). Neste conto, um casal chega a uma praia e depara-se com um jovem morto por afogamento, coberto por um lençol e cercado por pescadores, que se retiram dali em seguida. A alegria inicial de Clara gradativamente cede lugar ao mau humor, à inquietação e ao tratamento ríspido com o marido, que tudo faz para agradá-la. No entanto, Clara deixa o mar e decide deitar-se com o colo nu sobre a areia ao lado do morto. Sergio não compreende o desejo de Clara de ali permanecer e faz tentativas vãs visando à reconquista da esposa, com quem está casado há seis meses; ele questiona a si próprio sobre o porquê de seu casamento não ir bem. Sergio se sente incomodado com o desejo de Clara de ficar próxima do morto; esta pergunta-lhe as horas, irrita-se com as perguntas do esposo e pede que ele vá embora. Em seguida, o marido vê que os pescadores estão voltando com uma padiola improvisada a fim de transportaram o corpo do jovem, os quais respondem à Clara que o moço não tinha documentos, mas que tinha vindo à praia
} 
na tensão entre expor e ocultar e segue a mesma linha das peças teatrais citadas por Rosa no que concerne à interposição dos planos do passado e do presente e os deslocamentos no tempo e no espaço, assim como a presença de flashes de memórias. No filme, a protagonista Carla, casada com o arquiteto Maximo há cinco anos, enfrenta uma crise emocional. Enquanto passam um feriado em sua casa de verão em frente ao mar, Carla encontra Aldo, um jovem estudante com quem ela tem um breve, mas intenso relacionamento. Tentando ficar mais perto de seu marido, deseja repetir com ele a experiência vivida com Aldo, mas Maximo, um homem entediado e cínico, não entende o estado de ânimo de sua esposa e não corresponde às suas investidas. Carla decide que é chegada a hora de solucionar sua situação sentimental, marcada pela relação amorosa alienante com o esposo, e resolve levá-lo ao lugar onde ela encontraria Aldo novamente, a fim de desnudar os fatos. Ao chegarem à praia onde o encontro havia sido marcado, o casal encontra o corpo afogado de um belo jovem. Sua presença ali, morto, sob um lençol, a faz tomar a decisão de continuar a viver com o marido como se nada tivesse acontecido. O paralelismo entre o drama pessoal de Rosa e o vivido por Carla concentra-se principalmente na figura do homem amado idealizado, por quem ambas as protagonistas nutrem um amor platônico e uma paixão carnal, respectivamente. No caso de Carla, com a morte do amante, desfaz-se a ilusão de viver a grande paixão; por essa razão, seu silêncio é significativo, como se tivesse acordado de um belo sonho e se deparado com a realidade concreta - a traição deve permanecer encoberta. De modo semelhante, Rosa Ambrósio, fingindo ignorar a traição de Gregório, repete o mesmo esquema de Carla, na medida em que 'acorda' do sonho do casamento feliz dos primeiros tempos, durante os quais o esposo pareceu o perfeito substituto para a figura do bem-amado, Miguel; na verdade, sob o pretexto da 'traição' de Gregório, oculta-se a traição maior de Rosa, motivo que a leva a buscar o amor que sentiu por Miguel continuamente em outros homens. Assim, Rosa e Carla passam por uma espécie de 'educação sentimental', que parece ensiná-las que só no plano da memória/passado elas podem viver plenamente felizes e que devem aprender na realidade concreta do mundo 'adulto', no qual não existe a perfeição, mas que é duro o suficiente para fazer estourar, tal qual nas bolhas de sabão, a fina película que separa sonho/realidade, vida/morte.

em uma Vespa. Com o movimento de retirada do corpo da areia, a cabeça do jovem pende para trás, libertandose do lençol, o que permite que o casal veja-lhe o rosto moreno e de traços finos, o qual poderia ter a mesma idade de Sergio. Clara afasta-se aos prantos, desesperada, e revela a Sergio que o morto não era nenhum estranho, mas que se tratava de seu amante, com quem havia marcado um encontro naquela praia. 
A essa altura, somos capazes de compor o mosaico que explica o fortalecimento repentino da personagem Miguel e o questionamento da atriz sobre o silêncio e afastamento de Gregório no início dos dois capítulos da gravação, com as provas espalhadas ao longo do texto: “(...) Miguel querido, onde você estiver, ouviu isso? eu te amo. Algumas coisas devem ficar na obscuridade, é melhor não levantar o pano, deixa... Acho que descobri, Gregório não me fez feliz porque ele era infeliz, o que mais poderia me dar senão sua tristeza" (HN, p.146grifo meu). Concomitantemente à projeção de toda a culpa da infelicidade conjugal sobre Gregório, Rosa tenta ocultar os sentimentos desigualmente partilhados por ela e o marido insistindo em negar a idealização da figura do primo como a responsável pelo quadro, que completa com as duas outras pistas que faltavam, mas que foram dadas pela autora implícita no momento em que Rosa metaforicamente depõe sobre uma árvore da Praça da República a 'cruz da memória': chorando copiosamente pela lembrança de Miguel no dia de seu casamento e fingindo não perceber a 'traição' de Gregório com a prima Zelinda no jantar em sua própria casa, revela-se o que ficara escondido por 'baixo do pano', isto é, na sua tentativa de existir publicamente, na função de atriz, Rosa leva a cabo seu ambicioso projeto de se tornar uma grande estrela e representar a mulher erudita, de classe, que as condições econômicas de sua família não puderam lhe oferecer, optando pelo 'polimento' vindo da ambição, que se afastava daquele desejado, oriundo do amor de Miguel, como sugere a peça de Marivaux.

Por essas razões, não parecem mais contraditórios o sentimento de culpa de Rosa por ter traído o marido com o antigo secretário, nem mesmo a revelação de que seu suposto renascimento se dera pelo telefonema de Diogo e não pela afirmação da atriz de que, se o marido falecido ordenasse, por caminhos que só os mortos como Eleonora e Zelinda conhecem, ele seria capaz de induzi-la a trabalhar e, portanto, a viver de novo. Assim, a convivência dessas personagens masculinas nas memórias se explica pela figura de Miguel e do mundo que ele representa. Pela morte, Gregório representa algo que pertence ao passado, mas que se faz presente como um fantasma com o qual a atriz tem débitos, e Diogo, embora tenha sido por ela expulso de sua vida, representa uma possibilidade de reconquista, de ingresso no mundo de sonhos idealizado, acompanhada da presença juvenil do amado. Nesse sentido, em seu universo repleto de opções, Rosa, como uma mulher que 'detesta escolher'(HN, p.13), continua vivendo o dilema de permanecer com um pé no mundo nostálgico e outro no desejo de conquistar aquilo que ela não tem, inerente à própria condição humana: no que concerne à protagonista de As Horas Nuas em especial, o doce pássaro da juventude, expresso na figura do amante. 
De acordo com esse ponto de vista, pode-se dizer que a nostalgia do passado, presente nas memórias gravadas, revela o verdadeiro 'lado direito das coisas', mas, sem os ecos e as pistas espalhadas ao longo do romance, alimentadas pelas mesmas distorções entre lembrar e esquecer, que se configuram aqui como fatos propositalmente até então esquecidos, elas não se sustentam como tal. Segundo a mitologia clássica, o rio do esquecimento, Lete, é apresentado como aquele que corre ao lado da fonte de Mnemósine, cujas águas tinham de ser bebidas por seus consulentes para terem acesso à revelação. Por outro lado, as águas de Lete deveriam ser ingeridas pelas almas que tornariam a viver em um novo corpo. Considerando a concomitante existência da lembrança e esquecimento, sugeridas pelas águas míticas de Lete e Mnemósine, pode-se dizer que as memórias, como mistura de emoções subjetivas e fatos objetivos, não têm valor de desnudamento interior da protagonista sem as revelações trazidas pelo monólogo interior delirante da própria personagem também calcado na memória - como as traições que fizera e que não integram as suas memórias gravadas - e pelo ponto de vista de Rahul. Lendo apenas as revelações selecionadas e por ela enunciadas, o leitor sabe que onde Rosa procura se revelar é que ela esconde o lado "torto das coisas", a decadência do modelo de família burguesa à qual pertence, já que, para a personagem, “(...) lembrar é também uma forma de esquecer o presente, que considera feio, degradado, desorganizado (...)"315, no que diz respeito a sua posição de ser e de estar no mundo, envolvendo tanto a vida interior quanto o mundo em que vive. Nas sessões com a analista, a atriz costumava dizer que

(...) as coisas na lembrança ficam tão mais belas. Viver infeliz na realidade e depois viver felicíssima na memória não seria a solução? perguntou. Para responder em seguida que isso podia acontecer com os outros mas na sua memória tudo era terrível. Um horror, acrescentou e virou a cara para a parede. Não quero mais falar, querida, quero ir embora. (HN, p. 83)

Embora hesite diante da possibilidade de viver de memórias, o que Rosa empreende, ao final do romance, é justamente o movimento em direção ao passado que considera belo, com as recordações da infância e da adolescência; esse movimento, no entanto, recupera incidentes e fatos que, na época em que ocorreram, não eram revestidos pela mesma aura de pureza com a qual Rosa procura impregná-los no presente, dado o distanciamento no tempo, mas que, em grande parte, eram fonte de sofrimento para a protagonista, mesmo em se tratando da ligação amorosa com Miguel. Isso indica que, se comparadas aos fatos posteriores ocorridos com Rosa, quando ingressa na vida adulta e com a chegada à velhice, suas

\footnotetext{
${ }^{315}$ LUCENA, Suênio C. Esquecimento e lembrança em Lygia Fagundes Telles. Op.cit., p.115.
} 
lembranças dos primeiros tempos surgem como período repleto de perspectivas e possibilidades e, por isso, ganham o direito de serem aparentemente divulgadas. Esse jogo de exposição e ocultamento, que se alimenta da tensão entre passado e presente - tanto individual quanto social - é o mecanismo da própria memória que sustenta a construção de Rosa: o exercício da rememoração, a partir da palavra, acaba revelando, na impossibilidade de separar o que é deformação ou acréscimo, entre lacunas e lembranças, a necessidade de repensar o tempo que não volta mais para compreender o atual, esvaziado de sentido, fruto das profundas alterações no seio das relações sociais e pessoais, e projetar-se para o futuro. Isso indica, na linguagem empregada pela protagonista, as preocupações anteriores da atriz agora afastada dos palcos, as quais ela deseja excluir de suas memórias ditadas ao gravador, em que só deveriam permanecer "as horas felizes", num esforço, portanto, ambíguo de apagamento do passado e sua reescritura, uma chance de viver com Diogo o que não fora possível com Miguel. Como a reflexão é parte do presente e neste não há a realização de nenhum outro tipo de ação que não seja gastar o tempo ociosamente, Rosa não sabe dizer "que livro vai sair com as memórias do mês passado" (HN, p. 45), exatamente porque os fatos mais recentes não integram o lado belo das coisas, como vimos. Sua posição como autora das memórias, aqui, é semelhante à dos escritores do século XIX que se utilizavam da técnica de representação realista, com a interpretação das ações, das situações e de suas personagens, do indivíduo em sociedade, com segurança objetiva, visão compartilhada por Philippe Lejeune, que acredita na transparência da linguagem, na possibilidade de existência de um sujeito pleno que se exprima através da linguagem, no compromisso de dizer a verdade e de que seu nome próprio garanta sua autonomia e singularidade, no que concerne à autobiografia. $\mathrm{O}$ leitor percebe que Rosa tenta representar a "identidade de sua experiência", pois acredita que tem "algo especial a dizer" 316 - que é, de certo modo, o mote de qualquer livro de memórias ou autobiografia-, mas a explosão de sua subjetividade, com a diminuição da distância do mundo narrado, entrecorta a tentativa de relato objetivo e revela a tensão entre o efeito reparador dessa subjetividade e o efeito de real que ela deseja dar às suas memórias, característicos da retórica testemunhal. Isso também se aplica à tentativa de uso do princípio da causalidade, aspecto importante nas memórias que Rosa se propõe a fazer, como forma de evitar as repetições existentes em seu próprio monólogo e, com elas, fraturas e brechas que

\footnotetext{
${ }^{316}$ Segundo Adorno, só a postura de um narrador permite essa identidade, isto é "a vida articulada e contínua em si mesma", mas, no romance contemporâneo, isso se desintegrou. ADORNO, Theodor W. Posição do narrador no romance contemporâneo. In: BENJAMIN, Walter; HORKHEIMER, Max; ADORNO, Theodor W.; HABERMAS, Jurgen. Textos escolhidos. Op.cit., p. 269.
} 
possam fazer o futuro leitor duvidar de sua posição de centro detentor da verdade, que possam colocá-la em xeque. Com isso, no entanto, a autora implícita mascarada por trás de Rosa revela justamente que "quanto mais estrito o apego ao realismo da exterioridade, ao "foi de fato assim', tanto mais cada palavra se torna um mero faz-de-conta, tanto mais cresce a contradição entre sua pretensão e a de que não foi assim" ${ }^{\text {"317, }}$, se pensarmos justamente na figura recoberta por máscaras que é Rosa. Assim, na fronteira especular entre a memória exercitada pelo fluxo de consciência da atriz e de seu gato ao longo de todo o romance, e a memória ficcionalizada na produção de um suposto livro de caráter autobiográfico, tem-se o desnudamento real da protagonista.

$\mathrm{Na}$ estratégia de organização do romance adotada por Lygia como autora implícita, as memórias inconclusas - pois Rosa grava apenas dois capítulos-depoimentos antes de se internar voluntariamente em uma clínica de desintoxicação - têm uma razão de assim o ser também no plano formal da obra: iniciando a leitura da narração em Miguel e terminando em Gregório, o leitor tem matéria suficiente para decifrar mais uma faceta do jogo de representação da protagonista no romance. Lygia propõe ao leitor um discurso de Rosa sobre si mesma, promovendo, concomitantemente, uma "realização particular" desse discurso no qual, nas palavras de Lejeune, “à resposta a 'quem sou eu?' constitui uma narrativa que diz "como me tornei assim"”, mas às avessas. Diferentemente do que ocorre em uma autobiografia convencional, Rosa Ambrósio é levada a responder ao 'como se tornou assim' com uma narrativa que se assemelha a uma viagem ao interior de si mesma começando pelo fim, em busca do próprio eu, o qual se tornou, para homens e mulheres, um 'projeto reflexivo', "uma interrogação mais ou menos contínua do passado, do presente e do futuro" ${ }^{\text {}} 18$, projeto que encontra eco nos recursos reflexivos utilizados por Rosa Ambrósio. Assim, os capítulos gravados respondem, em ordem inversa, àquela pergunta, mostrando como Rosa se tornou o que vimos, mas apenas nos capítulos anteriores. A partir dessa organização, a autora implícita realiza o resgate de representações de mulheres da classe média e da alta sociedade paulistana de meados do século XX, que coincidem com o percurso de Rosinha a Rosa, anterior à carreira de atriz, e das mulheres de sua família - mãe, tias e

\footnotetext{
${ }^{317}$ ADORNO, Theodor W. Posição do narrador no romance contemporâneo. In: BENJAMIN, Walter; HORKHEIMER, Max; ADORNO, Theodor W.; HABERMAS, Jurgen. Textos escolhidos. Op.cit., p. 271.

${ }^{318}$ GIDDENS, Anthony. A transformação da intimidade. Op.cit., p. 41. Em sua análise sobre a transformação da intimidade, o autor concentra-se no estudo de uma ordem emocional que está na origem do relacionamento puro e da sexualidade plástica, característicos de tempos recentes, e atribui essas mudanças na área da sexualidade, à expansão da reflexividade institucional que é característica distintiva das sociedades modernas no que se refere à contínua incorporação reflexiva do conhecimento, propiciada, dentre outros fatores, pela maior mobilidade geográfica e pelos meios de comunicação de massa.
} 
primas, resgate este cronologicamente situado no período que abrange o relacionamento com Miguel ao início de sua história com Gregório, da adolescência ao início da idade adulta. Isso confirma a visão de Lejeune que, com base na tentativa de explorar a história de sua própria família, descobriu que o "inconsciente não se decifra apenas através de sonhos e lapsos, mas também na trama da história da família.,319

Neste ponto, cabe fazermos uma reflexão sobre o título do romance, sob uma nova perspectiva. Em “A sauna”, como observam Almeida ${ }^{320}$ e Silva ${ }^{321}$, surge pela primeira vez a expressão 'As Horas Nuas', que daria título ao romance publicado em 1989, no qual já se encontram traços embrionários da composição da protagonista Rosa Ambrósio. Trata-se de um conto em que um pintor famoso, durante uma sauna, faz uma auto-análise, um mergulho em si mesmo a fim de compreender seu estágio atual de artista que sucumbiu às seduções do mercado e de homem que 'perdeu o fervor' também na vida pessoal, abandonando na juventude, à própria sorte, a namorada pobre e grávida para se casar com uma moça de família abastada. Do mesmo modo que Gaby, de um conto homônimo de Lygia, o protagonista de "A sauna" sucumbe às artimanhas do alto padrão de vida burguês, que em troca exige a manutenção da representação de uma ordem familiar e social que, acima de tudo, possa fazer valer os ditames de sua classe:

Vem pela fresta da porta uma lufada fria de ar. E a música. Me encolho,
cubro a cara com as mãos e apoio os cotovelos nos joelhos. (...) Me
descubro. As lágrimas correm mais espaçadamente, revigoradas em seu
trajeto pelas veredas de suor. Fico olhando num só ponto (...) olhar um ponto
em frente (...) e no silêncio, sem mentira, sem disfarce, ir se desvencilhando
das camadas que se acumularam - As horas nuas, foi um livro? Um filme?
Deixar ir caindo o que não for verdadeiro. Mas será que eu posso fazer essa
seleção, eu?! Tudo está tão misturado (...).

A semelhança entre Rosa Ambrósio e o protagonista masculino inominado são notórias: a sede de riqueza ofuscou as relações e permitiu as traições, com a diferença de que o conflito vivido por Rosa encontra-se historicamente datado, na arqueologia da artista, que se inicia no final da década de 40 e que por essa razão mesmo permite fazer uma leitura

\footnotetext{
${ }^{319}$ LEJEUNE, Philippe. O pacto autobiográfico (Bis). In: LEJEUNE, Philippe; NORONHA, Jovita M. G. (org.) O pacto autobiográfico. Op.cit., p. 67.

${ }^{320}$ ALMEIDA, Sandra R.G. Castration and melancholia in Lygia Fagundes Telles' As Horas Nuas. Op.cit..

${ }^{321}$ SILVA, Vera M. T. As Horas Nuas, um jogo de deciframento. In: A ficção intertextual de Lygia Fagundes Telles. Op.cit., p.34.

322 TELLES, Lygia F. A sauna. In: Seminário dos Ratos. Posfácio de José Castello. São Paulo: Companhia das Letras, 2009, p. 74.
} 
amparada nas marcas deixadas no texto de um período repleto de transformações cruciais que contribuíram para a modernização do país e para a emancipação da mulher em diversos sentidos. Segundo Silva, no entanto, "se o narrador de 'A sauna', em sua confissão solitária, expõe cruamente suas culpas e delas se liberta, a protagonista do romance não consegue fazer o mesmo (...) Suas Horas Nuas não são, pois, tão nuas assim»323. Para a autora, Rosa não consegue realizar o mesmo processo de renascimento do protagonista do referido conto porque "sendo atriz, é-lhe impossível ser ela própria"324. Ora, o fato de ser atriz não constitui impedimento para o desnudamento de Rosa; antes, trata-se de um recurso estilístico utilizado por Lygia para revelar que o processo de renascimento e libertação da personagem feminina é muito elaborado, e até mesmo mais difícil do que o da personagem masculina, tamanha a carga de representações de comportamentos e escolhas condicionadas aos padrões até pouco tempo tidos como 'adequados' que se acumularam sobre a figura feminina. Rosa ensaia seu desnudamento ao longo do romance, mas não o atinge em plenitude: embora se desfaça da metafórica 'cruz da memória', ao gravar suas memórias ela as reveste mais uma vez de papéis, desta vez, positivos; por outro lado, o protagonista do conto, que assim como Rosa está soterrado pelas inúmeras representações que seu estilo de vida proporcionara - que é o mesmo alcançado pela protagonista de As Horas Nuas -, consegue, ao contrário da atriz, chegar ao âmago, libertando-se dessas camadas metonimicamente vertidas em suor e lágrimas durante a sessão da sauna. Nesse sentido, Rosa, como autora das memórias, corrobora essa visão e permite vislumbrar o pacto fantasmático que Lygia Fagundes Telles, como autora do romance, realiza em mise en abyme. Adotando essa postura, Lygia reafirma o espaço ficcional, a literatura, como o lugar privilegiado para a discussão da marginalidade ${ }^{325}$ e das transformações vividas pela mulher, na medida em que propõe ao leitor, segundo a visão de Lúcia Helena Vianna, apresentada na introdução deste trabalho, um 'pacto memorialístico' para a leitura do romance, no qual uma possível verdade sobre a natureza humana caminha lado a lado com os 'fantasmas' reveladores do indivíduo.

\footnotetext{
${ }^{323}$ SILVA, Vera M. T. As Horas Nuas, um jogo de deciframento. In: A fiç̧ão intertextual de Lygia Fagundes Telles. Op.cit., p. 35. Elódia Xavier apresenta uma perspectiva complementar a respeito da nudez do tempo transcorrido nas memórias da atriz: "Rosa Ambrósio tem consciência de sua decadência (...) e esta consciência vai colaborar na reconstituição de suas memórias, pois os processos memorativos se relacionam com os campos de significação da vida presente do sujeito que recorda. Assim, a apreensão plena e pura do tempo passado é impossível, como as ‘horas nuas' de seu projeto das memórias”. XAVIER, Elódia. O corpo envelhecido. In: Que corpo é esse?. Op.cit., p. 92.

${ }^{324}$ SILVA, Vera M. T. As Horas Nuas, um jogo de deciframento. In: A fiç̧ão intertextual de Lygia Fagundes Telles. Op.cit., p. 35.

${ }^{325}$ JOSEF, Bella, Reflections on recent Brazilian fiction. Review of Latin American Literature and Arts. [S.I.], n. 48, Spring 1994, p. 46.
} 
Se considerarmos que a memória também veste uma máscara, porque nela entra uma boa dose de invenção, observaremos que as memórias intituladas As Horas Nuas passam por um processo duplo de mascaramento, porque Rosa precisa despetalar-se, despir-se das personagens que lhe estão arraigadas, das diversas representações de mulher que lhe estão inerentes na metáfora da atividade teatral, para tentar chegar ao miolo, à raiz. As verdadeiras As Horas Nuas, portanto, são as que constituem o romance em sua totalidade, e por isso o livro carrega o mesmo título das ditas memórias feitas pela protagonista, índice de mais um jogo de espelhamento do texto ${ }^{326}$. Por essas razões, pode-se dizer que essas memórias, como gênero, ao mesmo tempo em que revelam um passado recôndito de Rosa com o qual ela parece acertar as contas, concomitantemente funcionam como mais um instrumento capaz de ocultar suas relações com esse mesmo passado, em total consonância com a tensão estruturante de As Horas Nuas. A aparente sensação de alívio é questionável, como se vê, porque, falar do passado implica falar do presente e também do futuro.

Assim, o contrato entre Rosa, como autora, narradora e protagonista das memórias, e o leitor, como aquele que acredita na 'verdade da personagem' é rompido definitivamente ao final de As Horas Nuas justamente porque este último é capaz de pôr à prova, à verificação, as memórias da atriz como matéria que só pode ser narrada por ela mesma, em que estão guardadas apenas as 'horas felizes'. O pacto referencial não se aplicaria porque tais memórias remetem a um tempo no qual as testemunhas estão todas mortas - não há como comprová-las: o leitor tem de aceitá-las (ou não) como verdadeiras. No entanto, a estratégia de contrapor a personagem principalmente à visão de outro personagem/testemunha, Rahul, permite a referencialidade nos outros capítulos do romance, ao revelar outras nuances das memórias mais pungentes que jorram, ao resgatar, inclusive, diálogos e situações que envolvem outras personagens e que, no presente da narrativa, já não fazem mais parte do círculo de

\footnotetext{
${ }^{326}$ Partindo de uma perspectiva diferente da que adoto neste trabalho, Sandra Almeida considera que o romance que chega às mãos do leitor com o título As Horas Nuas é fruto das memórias, o próprio livro de memórias da atriz Rosa Ambrósio e observa que as três vozes narrativas do romance - Rosa, Rahul e Ananta- estão relacionadas e pertencem a uma estrutura que repousa sobre a suposição de que o romance é de fato as memórias de Rosa. A atriz refere-se constantemente às suas memórias como As Horas Nuas, o que sublinha o medo de Rosa da morte e seu aparente desejo de alcançar a juventude eterna e a imortalidade. Rahul, como espelho de Rosa, seria uma criação da atriz, e o narrador impessoal que traz à tona os pensamentos de Ananta supostamente seria a própria Rosa, criando uma distância entre a narração em terceira pessoa e aquela que tem a atriz como foco, através de si mesma e do gato. Essas ideias, como afirma Almeida, são enfatizadas pela própria visão de Lygia Fagundes Telles de que o objetivo do artista é permanecer e, nesse sentido, a obra de arte seria uma espécie de negação da morte e uma forma de narcisismo. Assim, a tentativa de Rosa escrever suas memórias poderia estar relacionada, segundo a pesquisadora, com sua natureza narcísica e seu desejo de escapar à velhice e à morte. ALMEIDA, Sandra R.G. Castration and melancholia in Lygia Fagundes Telles' As Horas Nuas. Op.cit..
} 
convivência de Rosa, embora participem ativamente de seu repertório: Gregório, Diogo, seus pais, a família de Miguel, a tia abastada que deixara como herança boa parte da fortuna que sustenta o alto padrão de vida da própria Rosa e da filha Cordélia.

\subsection{Memória e criação literária}

O romance As Horas Nuas aponta discretamente, no nível temático, o início do período democrático no Brasil, se comparado ao último romance publicado por Lygia antes de As Horas Nuas, As meninas (1973), o qual acompanhou, de certo modo, a tendência da literatura produzida nos anos 70, isto é, o caráter documental como forma de reação literária à censura imposta pelo regime militar. A autora denuncia, a partir das relações que estabelece entre as três principais figuras femininas do livro, as mudanças de âmbito cultural assim como as atrocidades do regime, fazendo referências explícitas à ditadura, especialmente quando inclui, quase na última parte de As Meninas, através da leitura feita pela personagem revolucionária, Lia, um panfleto que circulou à época em que o romance foi produzido, no qual um jovem militante de esquerda, vítima dos militares, contava em detalhes os procedimentos de tortura aos quais fora submetido.

A mudança de perspectiva de Lygia em As Horas Nuas com relação ao romance publicado em 1973 pode ser analisada como uma questão que envolve o panorama literário e o contexto em que o romance foi publicado. Findos o regime e a censura, o ambiente cultural encontrava-se mais 'arejado' para que os escritores pudessem escrever, já não sendo mais necessária a criação de mecanismos velados de denúncia. No entanto, como outros escritores da década de $80^{327}$, Lygia parece ter ido buscar outras fontes para solucionar um dilema que então se colocava para boa parte dos escritores, expresso na dúvida sobre para quem escrever, 'problema' criado com a nova contextualização - não só no âmbito político, mas também, social e cultural. Dentre as formas encontradas para driblar esse impasse, Flávio Carneiro destaca que a ficção produzida no período procederia ao cruzamento da literatura com outras linguagens, como a incorporação da linguagem do ensaio e da mídia, à transgressão radical com relação à temática erótica e, especialmente, a uma releitura do período utópico ${ }^{328}$

\footnotetext{
${ }^{327}$ CARNEIRO, Flávio. No país do presente - Ficção brasileira no início do século XXI. Rio de Janeiro: Rocco, 2005, passim.

${ }^{328}$ O poeta, ensaísta e tradutor Haroldo de Campos define como utópico um período caracterizado por uma "esperança programática" que permitia "entrever no futuro a realização adiada do presente". CAMPOS, Haroldo.
} 
período que se estende dos anos 20 ao final dos anos 60, marcada nesta última década pela estreita ligação entre cultura e política - uma espécie de balanço em que a ruptura absoluta e a literatura engajada, características da década de 70, são recusadas de alguma forma, em favor de uma "reescritura que se pretende retorno e avanço". O autor rejeita a expressão "pósmoderno" para caracterizar a literatura produzida a partir da década de 80, devido a problemas inerentes que essa terminologia poderia trazer, como a indicação de uma espécie de ruptura com o moderno, que o prefixo pós- poderia sugerir, posição com a qual concordo. Prefere, então, a expressão "pós-utópico", utilizada por Haroldo de Campos em seu ensaio sobre poesia e modernidade, com a qual o crítico define o momento em que estamos vivendo desde o fim da década de $60^{329}$, quando se instaura o golpe de 64 , o consequente autoritarismo e a frustração de expectativas no plano nacional, e a crise das ideologias no plano internacional, levando a poesia a esvaziar-se de sua 'função utópica ${ }^{330}$. Acompanhando o raciocínio de Campos, Carneiro afirma que, no âmbito da ficção em prosa, "se já não cabe mais falar em princípio-esperança, que norteou os projetos da modernidade, há como vislumbrar a trilha da incerteza, dos pequenos projetos, da incompletude."

Esse traço de ordem cultural pode ser claramente observado em Rosa Ambrósio, mas expresso em seu dilema pessoal. Vencido o pessimismo com a nova configuração que a 'contaminou', expresso em suas queixas sobre a postura dos políticos, a violência, a vulgaridade, a decadência dos usos e costumes, a derrocada da fé, a solidão nas grandes cidades, a protagonista volta-se para o passado recôndito na gravação das memórias, pois isso representa tanto uma forma de 'recuo' aos tempos tidos como utópicos da adolescência, como de 'avanço' no que se refere à possibilidade de seguir adiante, como se na revisitação de uma época fértil em perspectivas, como foram também os anos anteriores ao golpe de 64, ela pudesse encontrar a motivação necessária para recomeçar e não cometer os mesmos erros do passado ou dar prosseguimento a outros projetos, menos pretensiosos.

Walter Benjamim, no clássico ensaio em que trata do 'desaparecimento' do narrador ${ }^{332}$,

Poesia e Modernidade: da morte da arte à constelação. O poema pós-utópico. In: O arco-íris branco: ensaios de literatura e cultura. Rio de Janeiro: Imago Ed., 1997, p. 265. (Biblioteca Pierre Menard)

${ }^{329}$ CAMPOS, Haroldo. Poesia e Modernidade: da morte da arte à constelação. O poema pós-utópico. In: $O$ arcoíris branco: ensaios de literatura e cultura. Op.cit., p. 265.

${ }^{330}$ Ibid., p. 268.

331 CARNEIRO, Flávio. No país do presente. Op.cit., p. 29. Com o uso da expressão “pós-moderno", entraríamos numa discussão que não se constitui como foco deste trabalho. Assim como Carneiro, julgo a expressão "pós-utópico" de maior abrangência para as questões discutidas nesta tese.

${ }^{332}$ BENJAMIN, Walter. O narrador- Considerações sobre a obra de Nikolai Leskov. In: Magia e técnica, arte e política. Op.cit.. 
aponta o surgimento do romance como um dos indícios da morte da narrativa. A expulsão gradual da "narrativa da esfera do discurso vivo", com a substituição do conselho do narrador épico pela informação, ocorre, para Benjamin, no processo de 'evolução secular das forças produtivas', associado “às formas mais antigas de trabalho manual”. Assim sendo, a arte de narrar passa a definhar porque a sabedoria está em extinção, posição corroborada pelo choque provocado pela Primeira Guerra Mundial, com o esgotamento do relato por ela provocado devido ao esgotamento da experiência como fato compreensível. Como observam Sarlo e Seligmann-Silva, isso se reflete na ideia do fim mesmo da possibilidade de narrar, provocado pelo trauma de uma situação-limite, vivida pelos sobreviventes do Holocausto, da Guerra do Vietnã ou das ditaduras estabelecidas na América Latina, por exemplo. Essas posições convergem no paradoxo do desejo de falar de si e da impossibilidade de expressar uma verdade no processo de escrita. Tais considerações permitem analisar o desejo de registro da experiência vivida por Gregório, esposo de Rosa, que costumava escrever 'coisas curtas' em papéis lançados em seguida ao cesto de lixo, num outro viés, menos otimista, expresso na provável dificuldade de escrever frente ao trauma. Isso também oferece matéria para discutirmos mais uma faceta do jogo de exposição e ocultamento, em As Horas Nuas, no que se refere à ligação entre memória e criação literária.

A autora implícita utiliza-se do recurso da indiferença da atriz, revelada por Rahul, no que diz respeito ao conteúdo escrito por Gregório nesses papéis, para abrir uma fresta sobre o silêncio quase completo das personagens a respeito do período ditatorial, principalmente no tocante à protagonista. Quando indagado por Rosa sobre essa escrita, o professor desconversava: "Por que você escreve e destrói em seguida? Ele sacudiu a cabeça, só rabiscos, não era nada. Nada" (HN, p.37- grifo meu). Questionada por Diogo sobre a falta de 'curiosidade' sobre tais escritos, a personagem mascara sua indiferença com a afirmação de que se trata de 'respeito' ao esposo. Paira sobre Gregório, portanto, uma pesada sombra de incertezas acerca do conteúdo dessa escrita, o que possivelmente revelar-se-ia como testemunho vivo de sua experiência de intelectual que se rebelou contra o regime - expresso, quiçá, em um livro de testemunho, de memórias ou até mesmo uma autobiografia. Não é por acaso que os dois capítulos inerentes às memórias da atriz remetam, antes do início da gravação propriamente dita, à lembrança de Gregório pós-tortura como um ‘outro’ homem:

(...) E me lembro agora de um caso tão estranho que [Gregório] me contou, o caso do rio assassino que rejeitava uma certa espécie de peixe, não queria esse peixe em suas águas. E o pobre peixe se abraçando desesperadamente à água que o expulsava, que o cuspia para a terra. Os peixes expatriados. Que 
precisavam lutar com mais empenho do que os outros para a sobrevivência humilhante nas margens turvas, lá no fundo turvo do rio inimigo. Os peixes exilados. Na manhã em que ele foi embora debaixo daquela organza tolamente disfarçante pensei de repente nessa história terrível que um amigo lhe contou quando esteve exilado na França e daí comecei a chorar aos gritos porque vi nele o peixe cinza-descamado dentro da rede lilás. Na minha tonteira nem percebi que ele ligara essa história à sua própria história, era $\mathrm{o}$ peixe que o sistema-rio perseguiu e torturou com desvairado rancor até empurrar para a margem. Marginalizado até a morte.

Uma história tão pungente e só me lembrei dela quando vi sua cara cinzenta, esvaziada, ali estava ele de boca entreaberta, enquanto o rio prosseguia com toda a sua força, Ah! seus filhos-da-puta! Onde estão vocês agora que não aparecem para vir ver o que fizeram?!... (HN, p.195-196)

Na ficção de Telles, a metáfora da água apresenta um significado especial. Esse elemento surge principalmente associado a duas acepções fundamentais, ligadas à ideia de movimento ou de falta deste: parada em um aquário ou pertencente a um rio caudaloso ou a um mar bravio, constituem as respectivas metáforas de morte e vida. A pequena 'fábula' do rio assassino que expulsava um determinado tipo de peixe, os militantes de esquerda contra o regime, remete não só à supressão do direito de viver em e agir com liberdade, mas aos efeitos da 'captura': findo o regime, os milhares de peixes expulsos, exilados, expatriados encontram-se com a 'boca entreaberta'- desaparecidos, mortos ou incapazes de testemunhar, indignados pela punição recebida por terem se revoltado. Diante do quadro, a constatação de Rosa Ambrósio é a lição que permanece: "Não, não adianta se revoltar, Gregório se revoltou, partiu para o confronto e acabou cassado, dependurado, torturado. Sua linda cabeça pensante levando choque, porrada. Atingido no que tinha de mais precioso. Ferido para sempre" (HN, p.10-11). Em nome da ordem e do progresso, os responsáveis pelo sistema-rio rejeitavam aqueles que nadavam contra a corrente, ao passo que os verdadeiros 'subversivos' continuaram nadando livremente...

Gregório desenvolve o Mal de Parkinson. "Vi no dicionário as duas causas, senilidade ou traumatismo craniano, acontece muito com os pugilistas que levam pancadas frequentes" (HN, p.37). Assim, pela arte da alusão, Rosa Ambrósio revela as causas da doença do esposo: a tortura sofrida na prisão. A experiência de Gregório como alguém que foi cassado e torturado nunca foi por ele revelada: o silêncio passa a ser seu companheiro e guardião da memória, assim como Rahul, que, na condição de gato com o atributo humano da rememoração, também preserva os momentos mais poéticos da sua existência atrelada à do amado professor. Com a atitude de escrever e jogar fora, o marido de Rosa questiona a possibilidade mesma de escrever, assim como a quem destinaria seu suposto testemunho. Incapaz de registrar as agruras pessoais e coletivas em forma de relato, a atitude da 
personagem do professor universitário, como a de Rosa na gravação das próprias memórias, evidencia a relação entre testemunho e experiência e entre experiência e narração: “a linguagem liberta o aspecto mudo da experiência, redime-a de seu imediatismo ou de seu esquecimento e a transforma no comunicável, isto é, no comum. (...) A narração também funda uma temporalidade, que a cada repetição e a cada variante torna a se atualizar" ${ }^{\text {"33 }}$. O gesto de escrever e jogar o papel fora revela a articulação de duas forças que atuam sobre a testemunha: a necessidade de narrar a experiência vivida em uma situação-limite, como foi o caso da tortura sofrida por Gregório, como também a dificuldade de apresentação dessa e de prováveis outras experiências ligadas ao trauma, dificuldade essa que se deve tanto à insuficiência da linguagem diante de fatos tidos como impossíveis de serem narrados, quanto à percepção de seu caráter inimaginável e de um provável efeito de inverossimilhança decorrente. $^{334}$

Como Rahul acredita, conhecendo perfeitamente os membros de sua família, Gregório provavelmente desiste de escrever para não 'ocupar mãe e filha já ocupadas demais com suas próprias frivolidades' com uma responsabilidade como esta: a de torná-las guardiães de sua experiência posta em papel, que de uma maneira ou de outra acabaria como todos os seus objetos pessoais: doados, vendidos ou esquecidos na sala dos 'guardados', no apartamento da família. Prefere emudecer pelo suicídio. Ao optar pela morte, não emudece apenas o relato de uma experiência trágica, mas leva consigo os sinais e os vestígios de sua humilhação pessoal, numa digna 'saída de cena': as mãos trêmulas, constantemente ocultadas nos bolsos das calças e o andar cambaleante, mas também o medo da cadeira de rodas e da 'sopa colocada na boca' no futuro. Continuar vivo nas prováveis condições que o esperavam, representaria, para o professor Gregório, declarar o regime vencedor, ao manter inscrita no corpo a marca indelével, a chaga constantemente aberta, testemunhando na própria carne o horror a que foi submetido e a vitória de seus algozes. Sua atitude assinala a dialética da exposição e ocultamento: se o período é rico do desejo de testemunhar para não esquecer e impedir de algum modo a repetição da experiência, também convive com a vontade de apagar as lembranças, como forma de varrer um passado inglório da história coletiva e pessoal para retomar a vida em busca de uma nova história.

Embora acredite que a causa-morte do esposo resuma-se a um ataque cardíaco fulminante e desconheça/ignore seu suicídio, pela culpa que marca sua história com ele, Rosa

\footnotetext{
${ }^{333}$ SARLO, Beatriz. Tempo passado. Op.cit., p. 24-25.

${ }^{334}$ SELIGMANN-SILVA, Márcio. A língua como leito da memória cultural e meio de diálogo entre as culturas. In: MIRANDA, Danilo Santos de (org.). Memória e Cultura. Op.cit., p. 76-77.
} 
parece se sentir responsável, ao final do romance, por trazer à tona a memória de Gregório, estabelecendo, com isso, um paralelo com a exposição de suas próprias memórias. Deste modo, a protagonista cria um compromisso ético com o marido, rejeitado pela pátria e pela família, e com aqueles que, em nome da liberdade, fizeram por diversos caminhos, a travessia: falar do esposo, morto em decorrência da tortura, como o peixe odiado e perseguido pelo caudaloso rio assassino, é manter vivo, no próprio cerne da metáfora, o objetivo a que se destina qualquer ditadura: impor, pela supressão da liberdade, os interesses de poucos em detrimento de muitos, em nome de todos. Portanto, tornar a imagem de Gregório e dos outros presente numa figura de linguagem como a metáfora ${ }^{335}$, que concentra a comparação indireta em sua estrutura, configura-se, neste caso, como a forma mais eficaz de dar testemunho, na medida que não esquece de lembrar ao leitor os efeitos sempre devastadores de quaisquer regimes autoritários como foi o de 64, como um esforço de impedir que a história se repita.

Nos sentidos aqui expostos, pode-se dizer que a busca de Rosa é paralela à do escritor que, desembrulhando suas personagens, desembrulha-se a si mesmo. Na visão de Lygia Fagundes Telles, como escritora, isso engloba o esforço de se expressar por aqueles que não podem e/ou não têm acesso à palavra, com "o amor e a piedade que o escritor deve ter no coração", sua verdadeira função: "Escrever por aqueles que muitas vezes esperam ouvir de nossa boca a palavra que gostariam de dizer. Comunicar-se com o próximo e, se possível, mesmo por caminhos ambíguos, ajudá-lo no seu sofrimento. Na sua fé.”’336

\footnotetext{
335 É importante lembrar aqui que essa figura de linguagem, juntamente com a elipse, foram os recursos mais utilizados por escritores, dramaturgos, cineastas e compositores diante da impossibilidade de expressão durante os anos de chumbo da ditadura.

${ }^{336}$ MONTEIRO, Leonardo et al. Lygia Fagundes Telles. Seleção de textos, notas, estudos biográfico, histórico e crítico e exercícios. São Paulo: Abril Educação, 1980, p. 6. (Coleção Literatura comentada)
} 
(S) escritor escreve tentando recompor, quem sabe, um mundo perdido, os amores perdidos. \&le tenta se buscar nas personagens e se buscar em si mesmo; ele tenta recuperar o paraíso perdido. Sesse paraíso perdido, está a infância. ( Epgia $\circlearrowleft$ fagundes Telles- A inventora de memórias) 


\section{CERRANDO AS CORTINAS}

ncarar a vida com bom-humor, sonhar, cumprir a vocação são as chances
que temos para driblar as dificuldades e o pessimismo, mesmo que tenhamos que dançar, por vezes, "o tango das ilusões perdidas" (HN, p.41) - é o que as personagens de As Horas Nuas nos revelam. Nesse romance, Lygia capta as transformações ocorridas com a mulher brasileira a partir das relações familiares e sociais que se estabelecem a partir da experiência de Rosa Ambrósio e do jogo de espelhamento com outras personagens. No plano dos sofrimentos individuais dessas personagens, a escritora mostra como o malestar provocado pelos novos rumos tomados pelo Brasil pós-ditadura infiltra-se em todas elas, que se alimentam, cada uma a seu modo, de um pessimismo desolador. Mas apesar da decadência dos costumes e dos valores, da miséria transbordante, da violência, da corrupção na esfera política e das traições na vida privada, a autora insufla suas personagens com um poderoso instrumento de transformação: a esperança, o "Cavalgar triunfante sobre todos os azares!” (HN, p.16), como Rosa enfatiza na lembrança do verso de Shakespeare.

Nos relatos das experiências transformadoras das vozes narrativas do romance, espelha-se o trajeto de Telles como mulher escritora na busca do autoconhecimento, da recriação e da transcendência da condição humana, expressa na situação da mulher, que é a sua, através da palavra. Ao longo de todo o romance, através do exercício oral da palavra, Rosa empreende uma tentativa de recompor seu 'paraíso perdido', no qual a família nuclear, a inocência, o sonho e o romantismo davam a tônica das relações, num período de transição de caráter pessoal (da adolescência à velhice), historicamente localizado, que se situa justamente num período em que o país apresenta feições gradativamente mais urbanas e passa por transformações cada vez mais rápidas e geradoras de medo e insegurança. Por isso, sua catarse não se realiza na gravação das memórias, embora seja nesse momento que o mundo e os sonhos perdidos se revelem com contornos de nitidez. Ao contrário: é no episódio da Praça da República que a personagem sente e expurga o “(...) peso dramático das casualidades a desviar planos individuais (...)"337. Desse esforço, nasce a problemática da mediação que, no

\footnotetext{
${ }^{337}$ A expressão de que Sônia Régis faz uso e que está entre aspas refere-se a seus comentários gerais acerca da obra da escritora, mas que explicam adequadamente a situação de Rosa Ambrósio. RÉGIS, Sônia. A densidade do aparente. In: INSTITUTO MOREIRA SALLES. Cadernos de Literatura Brasileira - Lygia Fagundes Telles. Op.cit., p.88.
} 
romance em questão, pode ser observada na construção da protagonista a partir da representação de sua experiência social, encenada em diversos ângulos. Essa problemática, no fazer literário da escritora, revela-se no diálogo que ela mantém com a produção ficcional de outros autores, como a influência de temas e técnicas narrativas, e a retomada e recriação de personagens e situações de seus próprios textos pregressos.

Como aquele "discurso de duas vozes" ${ }^{338}$, com uma dominante e outra silenciada, de que nos falava Elaine Showalter, a trajetória pessoal de Rosa, individual e social, contém traços de um percurso coletivo da mulher em busca de sua autorrepresentação. O diálogo intertextual com o teatro descortina a encenação de uma história da sujeição da mulher pelo patriarcado, os entraves à sua emancipação e suas tentativas de alcançar a tal sonhada autointegração. Por outro lado, as representações de mulheres em Rosa - inclusive a da protagonista como Rosinha, nas memórias-, na sua constituição como personagem repleta de personagens, em seus papéis sociais como mãe, esposa, amante, patroa e atriz e na relação com seus espelhos verdadeiros, descortinam outras e outras representações de mulheres com suas experiências múltiplas. $\mathrm{O}$ fato de a protagonista ter sido uma mulher jovem e bela, mas também uma profissional talentosa e reconhecida aciona o questionamento da representação da mulher como forma de identificação com as imagens criadas pela mídia e o choque provocado com o início da velhice, em contraponto à de Dionísia, mulher pobre e negra, também na mesma faixa etária. Cordélia e Ananta funcionam como imagens prolongadas ou opostas àquelas representações, como personagens jovens, uma alienada e a outra engajada, repetindo a mesma dualidade Diogo/Gregório. Rahul é o grande espelho: voz solitária, à qual ninguém ouve, perspectiva ilimitada que permite ao leitor, no entanto, compreender o sentido da experiência humana de êxtase e sofrimento, alegria e dor ao longo dos tempos, circunscrevendo a agonia da atriz. Lygia, como escritora, realiza um movimento que traz de volta a protagonista ao espaço da 'casa', local privilegiado para a reflexão feminina, depois de suas incursões no espaço público, no sentido de problematizar as escolhas realizadas no passado e suas consequências no presente. Em contraponto às identidades fluidas como Cordélia, ou das sólidas feito pedra como Dionísia, em Rosa, mas também em Ananta, revelase a dificuldade da mulher de encontrar a medida, o seu próprio tom, diante da valorização ou a negação do amor como elemento constitutivo. Essa necessidade de definição, como vimos, delineia-se justamente no trânsito entre o desejo de autonomia individual (carreira

${ }^{338}$ SHOWALTER, Elaine. A crítica feminista no território selvagem. In: HOLLANDA, Heloísa B. (org.) Tendências e impasses. Op.cit., p. 53. 
profissional, estudos, adiamento e/ou negação da maternidade) e o investimento na experiência amorosa (dentro ou fora do casamento), tidos por muito tempo como opostos. Nessas personagens, a autora representa a busca de equilíbrio e compatibilidade desses dois campos como o ideal de livre desenvolvimento de si, que se mantém em razão de sua adequação às aspirações de liberdade e de realização íntima ${ }^{339}$ da atriz e da analista. A complexidade de seu processo de renascimento e libertação, expresso literariamente em símbolos e metáforas, corresponde à também complexa 'carga' de representações de comportamentos e escolhas tidos como 'adequados' que se acumularam sobre elas e das quais precisam se libertar. Desse modo, desmistificam-se nessas representações aqueles "mecanismos culturais de unificação, estereotipia e exclusão" 340 e os impasses contemporâneos nas relações de gênero, trabalho reconhecido por Lucia Helena Vianna como autêntico de uma poética feminista.

A dialética de exposição e ocultamento, princípio formal que organiza o romance a partir de Rosa e de suas relações com os demais personagens, baseia-se, portanto, num jogo em que invenção e memória, ficção e vida dão as cartas e expõem o que a protagonista tenta esconder, por trás de diversas máscaras, seus mais recônditos medos e anseios, inseguranças e contradições: seja o da ascensão econômico-social, a manutenção do tempo a seu favor, a busca dos amores perdidos ou a permanência do nome cintilando entre as grandes estrelas da história do teatro. Assim, um motivo temático - a representação teatral - se configura dialeticamente na própria estrutura da obra. Com isso, a verossimilhança não é comprometida. Antes, é mantida porque a organização e a coerência interna do romance são dadas pela articulação do real, tendo como eixo central a protagonista, com seu mundo de ilusão e fantasia, com seus espelhos e máscaras, levando o leitor, numa parceria carregada de cumplicidade com as intenções da autora, a decidir entre os limites que se impõem entre razão e invenção, na tentativa de sugerir o caminho seguido pelas personagens que, no romance, ficam sem uma resposta definida.

O jogo multifacetado e ambíguo de representação, cujos índices mais evidentes encontram-se na intertextualidade com peças teatrais, no uso da técnica do livro dentro do livro e em suas relações com os elementos simbólicos e metafóricos, garante a originalidade de As Horas Nuas. Essa matéria posta em trânsito na ficção de Lygia configura-se como

\footnotetext{
${ }^{339}$ LIPOVETSKY, Gilles. A terceira mulher. Op.cit., p. 49.

${ }^{340}$ VIANNA, Lúcia H. Poética feminista- poética da memória. In: Labrys- estudos feministas. Op.cit..
} 
memória que se nutre de outras referências literárias, memória que recupera o passado, memória como mecanismo de representação, que esconde e revela. Trata-se fundamentalmente, portanto, de memória como elemento da criação literária, integrante da poética memorialista/feminista da escritora, que, pelo exercício da palavra, evoca voluntária ou involuntariamente memórias individuais e coletivas, representações femininas do presente e do passado, em constante diálogo. Como romance que resiste às tendências pós-modernas de hipermimese e de hipermediação, apontadas por Alfredo Bosi como características de boa parte da literatura brasileira publicada nas últimas décadas, pode-se dizer que As Horas Nuas constituem uma busca e uma forma de "renovar por dentro a expressão literária mediante o escavamento da experiência pessoal." ${ }^{341}$

Essas representações desvendam, portanto, o diálogo de Lygia, como escritora, com a própria questão da criação literária. Em Rosa, como uma personagem repleta de personagens, a autora também revela a dificuldade do processo de escrita, do jogo com a palavra como tentativa de chegar ao âmago, para desembrulhar a si própria, como a autora costuma afirmar em entrevistas e depoimentos. Essa visão é confirmada na protagonista, coerente com a ideia já mencionada de que é na ficção que o escritor realiza o movimento de autoconhecimento. Por essas razões, o romance como um todo deixa entrever, na busca de Rosa, mas também de Rahul, uma posição ao falar da vida que se assemelha à de Rodolfo, do conto "Verde Lagarto Amarelo", no que se refere ao trabalho da escrita: “(...) assim queria escrever, indo ao âmago do âmago até atingir a semente resguardada lá no fundo como um feto",342. A autora do romance As Horas Nuas, Lygia Fagundes Telles, e a autora/personagem/narradora do pretenso livro de memórias As Horas Nuas, Rosa Ambrósio, espelham-se, portanto, no tocante à elaboração textual, que apresenta uma estrutura paralela: o ato de ditar as memórias ao gravador por não conseguir escrevê-las frente à ânsia de tudo registrar tem, para Rosa, as mesmas características que o ato da escrita para Telles, que considera a criação literária como "desespero e apaziguamento. Ousadia e insegurança. Ansiedade e celebração."

Pode-se dizer, portanto, que As Horas Nuas constituem a metáfora do mistério da criação literária para a escritora. Sua reflexão sobre a criação literária, sua 'poética feminista',

\footnotetext{
${ }^{341}$ BOSI, Alfredo. Literatura na era dos extremos. In: Rodapé. Crítica de Literatura Brasileira Contemporânea, n.2. São Paulo: Nankin, 2002, p. 175.

342 TELLES, Lygia F. Verde Lagarto Amarelo. In: Antes do Baile Verde. Op.cit., p.20.

${ }^{343}$ Id., Mysterium - Trechos do depoimento da autora na França, Sorbonne (Paris, 1993), durante um seminário a seu respeito. Disponível em: $<$ http://literal.terra.com.br/ligia_fagundes_telles/Novidades_Lygia/Mais/Estadao_12_out_1995.pdf > Acesso em: 18 nov. 2008.
} 
também é atravessada pela dúvida: quais são os limites entre invenção - imaginação, ficção e memória e o quanto essa indefinição permite mostrar e esconder, na tessitura narrativa, as transformações sociais, como a ocorrida com a mulher e com a instituição familiar durante quase meio século. Num sentido mais estrito, Rosa Ambrósio, Rahul e Lygia Fagundes Telles desejam vencer a morte a partir da palavra: o "antigo instinto de permanecer através da palavra - o desafio- à morte. A obsessão do infinito em nosso viver finito, o maior sonho de todo o criador." 344

${ }^{344}$ NEPOMUCENO, Eric. A palavra de Lygia Fagundes Telles permanece. O Estado de S. Paulo, São Paulo, 28 set. 1997. Cultura, Caderno 2, p. D-12. 


\section{BIBLIOGRAFIA}

\subsection{Da autora}

\subsubsection{Romances, contos e fragmentos}

FAGUNDES, Lígia. Porão e Sobrado. São Paulo [i.e. São Paulo: Brasil Editora], 1938. Praia viva. São Paulo: Livraria Martins Editora, 1944.

GOMES, Paulo E. S. e TELLES, Lygia. F. Capitu. 2. ed. São Paulo: Cosac Naify, 2008.

TELLES, Lygia. F. A disciplina do amor: fragmentos. Rio de Janeiro: Rocco, 1998. . A estrutura da bolha de sabão. Rio de Janeiro: Rocco, 1999. . A noite escura e mais eu. Rio de Janeiro: Rocco,1998. . Antes do Baile Verde. Rio de Janeiro: Rocco, 1999. das Letras, 2009 . Antes do Baile Verde. Posfácio de Antonio Dimas. São Paulo: Companhia . As Horas Nuas. 4.ed. Rio de Janeiro: Rocco, 1999.

Letras, 2010. - As Horas Nuas. Posfácio de José Paulo Paes. São Paulo: Companhia das . As meninas. 16.ed. Rio de Janeiro: Nova Fronteira, 1985 . Ciranda de Pedra. 27.ed. Rio de Janeiro: Nova Fronteira, 1984 . Conspiração de nuvens. Rio de Janeiro: Rocco, 2007. . Durante aquele estranho chá- perdidos e achados. Rio de Janeiro: Rocco, 2002. . Invenção e memória. Rio de Janeiro: Rocco, 2000. . Mistérios. Rio de Janeiro: Rocco, 1998. . O cacto vermelho. Rio de Janeiro: Editora Mérito, 1949. . Pomba enamorada ou uma história de amor e outros contos escolhidos. Porto Alegre: L \&PM, 1999. 
. Seminário dos Ratos. Rio de Janeiro: Rocco, 1998.

. Seminário dos Ratos. Posfácio de José Castello. São Paulo: Companhia das

Letras, 2009.

. Verão no aquário. Rio de Janeiro: Rocco, 1998.

\subsubsection{Crônicas, depoimentos e documentários}

BRASIL. Ministério da Educação. Lygia Fagundes Telles - a inventora de memórias. Documentário TV Tal. 8 jan. 2005 (28 min.). Série Mestres da Literatura e Grandes Educadores Brasileiros. Disponível em: $<$ http://www.dominiopublico.gov.br/pesquisa/DetalheObraForm.do?select_action=\&co_obra $=99990>$ Acesso em: 15 jan. 2009.

LYGIA por Lygia. Direção geral: Paulo Markun. Elenco: Eva Wilma, Regina Braga e Luciano Chirolli. Roteiro: Maria Adelaide Amaral. Série Autor por Autor. São Paulo: SESC TV/ TV Cultura, 2009. Disponível em: < http://www.tvcultura.com.br/especialcultura/?sid=793> Acesso em: 20 dez. 2009.

NARRARTE com Lygia Fagundes Telles. Direção: Goffredo da Silva Telles. Documentário, 1993. 1 fita VHS (20 min.).

RODA VIVA. Entrevista com Lygia Fagundes Telles. Apresentação: Matinas Suzuki. Entrevistadores: Ignácio de Loyola Brandão, José Castello, Ana Miranda, Jorge Escosteguy, Reinaldo Gama, Claudiney Ferreira. São Paulo: TV Cultura, out. 1996. 1 DVD (85min).

TELLES, Lygia F. A criação literária. No princípio era o medo. Original datilografado. s/d. Disponível em: $<$ http://literal.terra.com.br/ligia_fagundes_telles/Novidades_Lygia/Mais/A_cria\%E7\%E3o_Li ter\%E1ria_-_Lygia.pdf> Acesso em: 18 nov. 2008.

- A mulher escritora e o feminismo no Brasil. Texto editado por Cristina Ferreira Pinto. In: SHARPE, Peggy (org.). Entre resistir e identificar-se: para uma teoria da prática narrativa brasileira de autoria feminina. Florianópolis: Ed. Mulheres; Goiânia: UFG, 1997, p.57-63.

Mulher, Mulheres. In: DEL PRIORE, M (org.). História das Mulheres no Brasil. São Paulo: Editora UNESP/ Contexto, 1997, p.669-672.

. Mysterium - Trechos do depoimento da escritora na França, Sorbonne (Paris, 1993), durante um seminário a seu respeito. Disponível em: $<$ http://literal.terra.com.br/ligia_fagundes_telles/Novidades_Lygia/Mais/Estadao_12_out_199 5.pdf $>$ Acesso em: 18 nov. 2008.

. Personagens gostam da vida, como nós. O Estado de São Paulo, São Paulo, 12 out. 1995. Caderno 2, p. D-5. 


\subsection{Sobre a autora}

\subsubsection{Entrevistas e artigos em periódicos}

ABREU, Caio Fernando. As horas de Lygia. Isto é Senhor, São Paulo, 21 jun. 1989. Seção Cultura, p. 88.

A primeira-dama da literatura. Zero Hora, Porto Alegre, 06 jan.

1996. Disponível

em:

$<$ http://literal.terra.com.br/ligia_fagundes_telles/bio_biblio/sobre_ela/artigos/imprensa_artigo s_primeira_dama.shtml?biobib̄io $>$ Acesso em: 18 nov. 2008.

ALMEIDA, Sandra R.G. Castration and melancholia in Lygia Fagundes Telles' As Horas Nuas. Disponível em: $\quad<$ http://tell.fll.purdue.edu/RLA-Archive/1991/Spanishhtml/Almeida,Sandra.htm> Acesso em: 10 abr. 2007.

ALMEIDA, Sérgio. A loucura é essencial. Jornal de Notícias, 13 out. 2005. Cultura, p. 45. Disponível em: Portal Literal. $<$ http://literal.terra.com.br/ligia_fagundes_telles/Novidades_Lygia/Premios/Jornal_de_Not\%E Dcias_(13_out_2005).pdf $>$ Acesso em: 18 nov. 2008.

BRASIL, Ubiratan. Lygia muda As Meninas de casa. O Estado de S. Paulo, São Paulo, 06 nov. 2008. Disponível em: $<$ http://www.portalliteral.com.br/imprime_artigo/lygia-muda-asmeninas-de-casa> Acesso em: 08 dez. 2008.

CASTELlO, José. Realidade rouba os sonhos de Lygia Fagundes Telles. O Estado de São Paulo, São Paulo, 06 jun. 1998. Disponível em: $<$ http://literal.terra.com.br/ligia_fagundes_telles/bio_biblio/sobre_ela/artigos/imprensa_artigo s_rouba_sonhos.shtml?biobiblio> Acesso em: 18 nov. 2008.

A menina e suas balzaquianas. Valor, São Paulo, sexta-feira e fim de semana - 11,12 e 13 abr. 2003, p. 7-9.

DUPONT, Wladir. Ofício da Paixão. Veja, São Paulo, Livros, p. 119, 19 nov. 1980.

FUKS, Julián. A vida para criar bolhas de sabão - Dossiê Lygia Fagundes Telles. Revista EntreLivros, Ano 3, n. 29, p. 22-26, set. 2007.

. Na dor, a busca da beleza. Entrevista com Lygia Fagundes Telles - Dossiê Lygia Fagundes Telles. Revista EntreLivros, Ano 3, n. 29, p. 27-31, set. 2007.

GOMES, Carlos Magno Santos. A paródia da autobiografia em Lygia Fagundes Telles. Acta Scientiarum Language and Culture. Maringá, v. 30, n.1, p. 79-84, 2008. Disponível em: $<$ http://www.periodicos.uem.br/ojs/index.php/ActaSciLangCult/article/viewFile/4058/2902> Acesso em: 10 out. 2008.

LEITE, Paulo Moreira. Lygia: sou uma testemunha das coisas ruins do meu tempo. Folha de S. Paulo, 17 jun. 1977. Disponível em: 
$<$ http://portalliteral.terra.com.br/ligia_fagundes_telles/bio_biblio/sobre_ela/reportagens.shtml ?biobiblio>. Acesso em: 18 nov. $200 \overline{8}$.

LUCAS, Fábio. Com açúcar e com afeto. Revista EntreLivros, Ano 3, n. 29, p. 32-34, set. 2007.

LUCAS, Fábio; PINTO, Manuel da Costa. Entrevista com Lygia Fagundes Telles. Cult Revista Brasileira de Literatura, São Paulo, ano 2, n. 23, p. 4-11, jun. 1999.

A Ficção giratória de Lygia Fagundes Telles. Cult - Revista Brasileira de Literatura, São Paulo, ano 2, n. 23, p. 12-15, jun. 1999.

LUCENA, Suênio Campos de. Qual o segredo de Lygia Fagundes Telles? Salvador. Disponível em: Portal Literal < http://literal.terra.com.br/ligia_fagundes_telles/Novidades_Lygia/Mais/Texto_de_Su\%EAnio _Campos_de_Lucena_Qual_o_segredo_de_LFT.pdf> Acesso em: 18 nov. 2008.

MARQUES, Fabrício. Contos de mistério e paixão. Jornal do Brasil, Rio de Janeiro, n. 480, 09 dez. 1995. Disponível em: $<$ http://literal.terra.com.br/ligia_fagundes_telles/Novidades_Lygia/Mais/JB_(9_dez_1995).pd f> Acesso em: 18 nov. 2008.

MARTINS, Wilson. Trechos de crítica sobre o romance As Horas Nuas. Original Datilografado, s/d. Disponível em: $<$ http://literal.terra.com.br/ligia_fagundes_telles/Novidades_Lygia/Mais/Trechos_de_cr\%EDt icas_do_livro_As_Horas_Nuas.pdf> Acesso em: 18 nov. 2008.

MEMÓRIA RODA VIVA. Entrevista com Lygia Fagundes Telles. 07 out. 1996. Disponível $\mathrm{em}:<\mathrm{http} / /:$ www.rodaviva.fapesp.br/materia/101/entrevistados/lygia_fagundes_telles_1996.ht $\mathrm{m}>$ Acesso em: 18 nov. 2008.

NEPOMUCENO, Eric. A palavra de Lygia Fagundes Telles permanece. O Estado de São Paulo, São Paulo, 28 set. 1997. Caderno 2, Especial Domingo, p. D-12.

PAES, José Paulo. A arte refinada de Lygia Fagundes Telles. O Estado de São Paulo, São Paulo, 23 dez. 1995. Cultura, Caderno 2, p. D-10.

PÓLVORA, Hélio. A primeira dama. Veja, São Paulo, p. 118, 13 jul. 1977.

PORTAL LITERAL. O engajamento de Lygia Fagundes Telles. Rio de Janeiro, 05 ago. 2008. Disponível em: <http://www.portalliteral.com.br/artigos/o-engajamento-de-lygia-fagundestelles> Acesso em: 18 nov. 2008.

SANTIAGO, Silviano. Romance traz o tango das ilusões perdidas. Folha de São Paulo, São Paulo, 20 maio 1989. Ilustrada, p. G-6.

SEREZA, Haroldo C. Lygia aumenta um ponto em cada conto. O Estado de São Paulo, São Paulo, 19 maio 2001. Caderno 2, p. D-3.

SQUEFF, Enio. Timidez e afirmação da escritora brasileira. O Estado de S. Paulo. São Paulo, 08 abr. 1973. Suplemento Literário, p. S. - 19. 
SZOKA, Elzbieta. So Many Worlds- So Many words: The Evolution of the Feminist Canon in the Brazilian Novel. Revista CiberLetras, v.07, July 2002. Disponível em: $<$ http://www.lehman.cuny.edu/ciberletras/v07/szoka.html> Acesso em: mar. 2003.

VÁRIOS AUTORES. Trechos de críticas do romance As Horas Nuas de Lygia Fagundes Telles. Original datilografado, s/d. Disponível em: $<$ http://literal.terra.com.br/ligia_fagundes_telles/Novidades_Lygia/Mais/Trechos_de_cr\%EDt icas_do_livro_As_Horas_Nuas.pdf $>$ Acesso em: 18 nov. 2008.

VASCONCELOS, Ana Lúcia. Lygia Fagundes Telles - Crio um livro como uma colcha de retalhos. Leia, São Paulo, maio 1986. Disponível em: $<$ http://www.cronopios.com.br/site/artigo.asp?id=3696> Acesso em: 08 dez. 2008.

VEIGA, José J. Uma viagem luminosa. Folha de S. Paulo, 14 jan. 1996. Caderno Mais!, p.510.

VIANA, Mário. O mundo de Lygia fora dos livros. Veja, 7/12/1988. Disponível em: $<$ http://portalliteral.terra.com.br/ligia_fagundes_telles/bio_biblio/sobre_ela/artigos/imprensa_ artigos_lygia_testemunha.shtml?biobiblio >. Acesso em: $1 \overline{8}$ ago. 2006.

\subsubsection{Dissertações, teses, artigos e capítulos de livros}

ALCANTÂRA, Liem Hani. Palavra: rota de salvação em Xerazade e Os Outros e As Horas Nuas. Tese (Doutorado em Estudos Comparados de Literaturas de Língua Portuguesa). Faculdade de Filosofia, Letras e Ciências Humanas, Universidade de São Paulo. São Paulo, 2007, 208p.

ATAÍDE, Vicente de Paula. A narrativa de Lygia Fagundes Telles. In: A narrativa de ficção. 2. ed. São Paulo: McGraw-Hill do Brasil, 1973, p. 91-111.

BISHOP-SANCHEZ, Kathryn. Entre a décadence e o imaginário: o caleidoscópio do envelhecimento em As Horas Nuas de Lygia Fagundes Telles. In: BARBOSA, Maria J. S. (org.). Passo e Compasso: nos ritmos do envelhecer. Porto alegre: EDIPUCRS, 2003, p. 175189.

COELHO, Nelly N. As Horas Nuas: a falência da razão ordenadora. In: feminina no Brasil contemporâneo. São Paulo: Siciliano, 1993, p. 235-248.

. A literatura

O mundo de ficção de Lygia Fagundes Telles. In: TELLES, Lygia F. Seleta. Organização, estudo e notas da Profa. Nelly N. Coelho. 3. ed. Rio de Janeiro: José Olympio, 1978, p.138-143. (Coleção Brasil Moço)

. Encontro com Lygia. In: TELLES, Lygia F. Seleta. Organização, estudo e notas da Profa. Nelly N. Coelho. 3. ed. Rio de Janeiro: José Olympio, 1978, p. viii- xiii. (Coleção Brasil Moço) 
CORONADO, Guillermo de La Cruz. Lygia e a condição humana. In: Letras de Hoje. Porto Alegre, PUCRS, v. 22, n. 1, p. 37-59, mar. 1987.

COUTINHO, Edilberto. Três mulheres e uma constante: Lygia Fagundes Telles, Maria Alice Barroso e Clarice Lispector. In: Criaturas de Papel - Temas de Literatura \& Sexo \& Folclore \& Carnaval \& Futebol \&Televisão \& Outros Temas da Vida. Rio de Janeiro: Civilização Brasileira; Brasília: INL, 1980, p. 155-170.

INSTITUTO MOREIRA SALLES. Cadernos de Literatura Brasileira n.5 - Lygia Fagundes Telles. São Paulo: IMS, março de 1998.

JOSEF, Bella. A arte de Lygia Fagundes Telles. In: O jogo mágico. Rio de Janeiro: José Olympio, 1980, p. 92-99.

LAMAS, Berenice Sica. O duplo em Lygia Fagundes Telles: um estudo em Literatura e Psicologia. Porto Alegre: EDIPUCRS, 2004.

LUCAS, Fábio. Mistério e Magia. In: TELLES, Lygia F. Antes do Baile Verde. 8. ed. Rio de Janeiro: José Olympio Editora, 1983, p.viii-xi.

LUCENA, Suênio Campos de. Esquecimento e lembrança em Lygia Fagundes Telles. Tese (Doutorado em Teoria Literária e Literatura Comparada). Faculdade de Filosofia, Letras e Ciências Humanas, Universidade de São Paulo. São Paulo, 2008, 183p.

. Lygia Fagundes Telles. 21 escritores brasileiros - uma viagem entre mitos e motes. São Paulo: Escrituras Editora, 2001.

MARTINS, Ana Paula dos Santos. Imagens e memórias em As Horas Nuas. In: MONZANI, Josette e MONZANI, Luiz R. (org.). Olhar: Imagem/Memória. São Paulo: Pedro e João Editores/CECH-UFSCar, 2008, p. 23-40.

MELO E SOUZA, Ronaldes de. Estudo introdutório - O conto de Lygia Fagundes Telles. In: TELLES, Lygia F. 10 contos escolhidos. Brasília: Horizonte; INL, 1984, p.25-32. (Coleção 10, v.11).

MONTEIRO, Adolfo Casais. Um romance de Lygia Fagundes Telles. In: O romance (Teoria e Crítica). Rio de Janeiro: José Olympio, 1964, p. 232-235.

MONTEIRO, Leonardo et al. Lygia Fagundes Telles. Seleção de textos, notas, estudos biográfico, histórico e crítico e exercícios. São Paulo: Abril Educação, 1980. (Coleção Literatura comentada)

OLIVEIRA, Kátia. A técnica narrativa em Lygia Fagundes Telles. Porto Alegre: Editora da UFRGS, 1972.

PAES, José Paulo. Entre a nudez e o mito. In: Transleituras. São Paulo, Companhia das Letras: 1995, p.41-45.

Ao encontro dos desencontros. In: INSTITUTO MOREIRA SALLES. Cadernos de Literatura Brasileira n.5 - Lygia Fagundes Telles. São Paulo: IMS, março de 1998, p.70-83. 
PEDRA, Mabel Knust. O círculo de giz: a família burguesa patriarcal em Lygia Fagundes Telles. Dissertação (Mestrado em Letras - Área de concentração: Estudos de Literatura). Niterói, Universidade Federal Fluminense, 2005, 115p.

PINTO, Cristina F. O bildungsroman feminino: quatro exemplos brasileiros. São Paulo: Perspectiva, 1990.

Consciência feminista/Identidade feminina: relações entre mulheres na obra de Lygia Fagundes Telles. In: SHARPE, Peggy (org.). Entre resistir e identificar-se: para uma teoria da prática narrativa brasileira de autoria feminina. Florianópolis: Ed. Mulheres; Goiânia: UFG, 1997, p.65-79.

RÉGIS, Sônia. A densidade do aparente. In: INSTITUTO MOREIRA SALLES. Cadernos de Literatura Brasileira n.5 - Lygia Fagundes Telles. São Paulo: IMS, março de 1998, p. 84-97.

RÓNAI, Paulo. A arte de Lygia Fagundes Telles. In: TELLES, Lygia Fagundes. Histórias escolhidas. São Paulo: Boa Leitura Editora, 1961, p. 7-11.

SANTIAGO, Silviano. A bolha e a folha: estrutura e inventário. In: INSTITUTO MOREIRA SALLES. Cadernos de Literatura Brasileira n.5 - Lygia Fagundes Telles. São Paulo: IMS, março de 1998, p.98-111.

SANTOS, Ana Paula dos. O eu e o outro: retratos de mulheres em dois romances de Lygia Fagundes Telles. Dissertação (Mestrado em Estudos Literários). Faculdade de Ciências e Letras, Campus de Araraquara, Universidade Estadual Paulista, 2004, 153p.

Algumas mulheres de Lygia Fagundes Telles. Relatório Final de Bolsa de Iniciação Científica - FAPESP, sob orientação da Profa. Dra. Tânia Pellegrini. São Carlos, 2000, p. 145p.

SCHWANTES, Cíntia. Preto no branco: as relações inter-raciais em As horas nuas e $\mathrm{O}$ eco distante da tormenta. Estudos de Literatura Brasileira Contemporânea, Brasília, n 28, p. 5970, jul.- dez. 2006.

SILVA, Lilian Cristina Brandi da. Do romance de formação à deformação do romance: $\mathrm{O}$ silêncio, Os teclados e As horas nuas. Tese (Doutorado em Letras- Literaturas em Língua Portuguesa). Instituto de Biociências, Letras e Ciências Exatas, Campus de São José do Rio Preto, Universidade Estadual Paulista, 2003, 151p.

SILVA, Vera M. T. As horas nuas, um jogo de deciframento. In: A ficção intertextual de Lygia Fagundes Telles. Goiânia: CEGRAF/UFG, 1992, p. 29-87.

VILLAÇA, Nízia. O olhar Barroco. In: Paradoxos do pós-moderno: sujeito \& ficção. Rio de Janeiro: Editora da UFRJ, 1996, p. 119-155.

XAVIER, Elódia. O corpo envelhecido. In: Que corpo é esse? O corpo no imaginário feminino. Florianópolis: Editora Mulheres, 2007.

\subsection{Geral}


ADELMAN, Miriam. O gênero na construção da subjetividade: entendendo a 'diferença' em tempos pós-modernos.... In: ADELMAN, Miriam; SILVESTRINI, Celsi B. (orgs.). Gênero Plural (coletânea). Curitiba: EdUFPR, 2002, p. 49-61.

ADORNO, Theodor W. Posição do narrador no romance contemporâneo. In: BENJAMIN, Walter; HORKHEIMER, Max; ADORNO, Theodor W.; HABERMAS, Jurgen. Textos escolhidos. 2. ed. Tradução José Lino Grunnewald et al. São Paulo: Abril Cultural, 1983, p. 269-273. (Os pensadores)

AGUIAR E SILVA, Vitor Manuel de. Teoria da Literatura. 8. ed. Coimbra: Almedina, 2005.

ALBEE, Edward. Who's afraid of Virginia Woolf? New York: Signet, 2006.

ANDRADE, Carlos Drummond de. Poesia Completa. Rio de Janeiro: Nova Aguilar, 2001. (Biblioteca Luso-Brasileira. Série Brasileira)

ANTONIO Candido. A personagem do romance. In: ANTONIO Candido et al. A Personagem de ficção. 11. ed. São Paulo: Perspectiva, 2007, p. 51-80.

. Formação da literatura brasileira- momentos decisivos 1750-1880. Rio de Janeiro: Ouro sobre azul, 2006. $\overline{\text { de Janeiro, } 2004 .}$

O Discurso e a Cidade. 3. ed. Duas Cidades/ Ouro sobre Azul: São Paulo/Rio . Literatura e sociedade - Estudos de Teoria e História Literária. 8.ed. São Paulo: T.A. Queiroz Editor, 2002.

. A educação pela noite e outros ensaios. 3. ed. São Paulo: Editora Ática, 2000.

ARISTÓTELES. Poética. Tradução Eudoro de Souza. São Paulo: Ars Poetica, 1993.

ASSOCIAZIONE Culturale Tonino Guerra. Pennabilli, 2007. Le ore nude: Trama. Disponível em: <http://www.toninoguerra.org/doc/le_ore_nude.htm> Acesso em: 12 nov. 2009.

AUERBACH, Erich. A meia marrom. In: Mimesis - a representação da realidade na literatura ocidental. 3. ed. São Paulo. Perspectiva, 1994, p. 471-498.

BACHELARD, Gaston. A poética do espaço. Tradução Antonio de Pádua Danesi. São Paulo: Martins Fontes, 1993. (Coleção Tópicos)

BARBOSA, Maria J. S. Corredores, labirintos e ritos de passagem para a idade avançada. In: (org.). Passo e Compasso: nos ritmos do envelhecer. Porto alegre: EDIPUCRS, 2003, p. 165-174.

BASSANEZI, Carla. Mulheres dos Anos Dourados. In: DEL PRIORE, Mary (org.). História das Mulheres no Brasil. São Paulo: Editora UNESP/ Contexto, 1997, p. 607-639.

BEAUVOIR, Simone de. O Segundo Sexo. 2. ed. Tradução Sérgio Milliet. Rio e Janeiro: Nova Fronteira, 2009. 2v. em 1. 
BEAUVOIR, Simone de. A velhice: as relações com o mundo. V.2. Tradução Heloysa de Lima Dantas. São Paulo: Difusão Européia do Livro, 1970.

BENJAMIN, Walter. A crise do romance. Sobre Alexanderplatz, de Döblin. In: Magia e técnica, arte e política: ensaios sobre literatura e história da cultura. 7. ed. Tradução Sergio Paulo Rouanet; Prefácio Jeanne Marie Gagnebin. São Paulo: Brasiliense, 1994, p.54-60. (Obras escolhidas, v. 1).

. O narrador- Considerações sobre a obra de Nikolai Leskov. In: Magia e técnica, arte e política: ensaios sobre literatura e história da cultura. 7. ed. Tradução Sergio Paulo Rouanet; Prefácio Jeanne Marie Gagnebin. São Paulo: Brasiliense, 1994, p.197-221. (Obras escolhidas, v. 1).

BETTI, Maria Silvia. Prefácio. In: O’NEILL, E. Longa jornada noite adentro: drama em 4 atos. Tradução Helena Pessoa. São Paulo: Peixoto Neto, 2004, p. 11-28. (Os grandes dramaturgos)

BONNICI, Thomas; ZOLIN, Lúcia O. (orgs.). Teoria Literária: abordagens históricas e tendências contemporâneas. 3. ed. Maringá: Eduem, 2009.

BONNICI, Thomas. Teoria e Crítica Literária Feminista: conceitos e tendências. Maringá: Eduem, 2007.

BOSI, Alfredo. Literatura na era dos extremos. In: Rodapé. Crítica de Literatura Brasileira Contemporânea n. 2. São Paulo: Nankin, 2002, p.170-176.

História Concisa da Literatura Brasileira. São Paulo: Cultrix, 1997.

BRAGA, Teófilo. A noiva do corvo. In: Contos tradicionaes do povo portuguez: com um estudo sobre a novellistica geral e notas comparativas. Porto: Livr. Universal,[19--], p. 66-68. Disponível em: <http://purl.pt/230/1/1-81262-p/1-81262-p_item1/P141.html> Acesso em: 20 jan. 2010.

BRANDÃO, Izabel; MUZART, Zahidé L. Refazendo Nós: ensaios sobre mulher e literatura. Florianópolis: Ed. Mulheres; Santa Cruz do Sul: EDUNISC, 2003.

BRANDÃO, Junito de Souza. Mitologia Grega. v.2. 4. ed. Petrópolis: Vozes, 1991.

BRADLEY, A.C. A tragédia shakesperiana: Hamlet, Otelo, Rei Lear, Macbeth. Tradução Marcelo Brandão Cipolla. São Paulo: Editora WMF Martins Fontes, 2009.

BRAVO, Nicole Fernandez. Duplo. In: BRUNEL, Pierre (org.). Dicionário de Mitos Literários. Tradução Carlos Sussekind et al. 4. ed. Rio de Janeiro: José Olympio Editora, 2005, p. 261-288.

BRUNEL, Pierre (org.). Dicionário de Mitos Literários. Tradução Carlos Sussekind et al. 4. ed. Rio de Janeiro: José Olympio Editora, 2005.

CAMPOS, Haroldo. Poesia e Modernidade: da morte da arte à constelação. O poema pósutópico. In: $O$ arco-íris branco: ensaios de literatura e cultura. Rio de Janeiro: Imago Ed., 1997. (Biblioteca Pierre Menard) 
CANEVACCI, Massimo (org.). Dialética da família. São Paulo: Brasiliense, 1982.

CARNEIRO, Flávio. No país do presente- Ficção brasileira no início do século XXI. Rio de Janeiro: Rocco, 2005.

CARROLL, Lewis. Aventuras de Alice no País das Maravilhas \& Através do Espelho e o que Alice encontrou lá. Rio de Janeiro: Jorge Zahar Ed., 2009.

CHEVALIER, Jean; GHEERBRANT, Alain. Dicionário de símbolos - mitos, sonhos, costumes, gestos, formas, figuras, cores, números. Tradução Vera da Costa e Silva et al. 22. ed. Rio de Janeiro: José Olympio Editora, 2008.

CHIAPPINI, Ligia. Mulheres, galinhas e mendigos: Clarice Lispector, contos em confronto. In: SUSSEKIND, Flora; DIAS, Tânia; AZEVEDO, Carlito (orgs.). Vozes Femininas: gênero, mediações e práticas da escrita. Rio de Janeiro: 7 Letras: Fund. Casa Rui Barbosa, 2003, p. 435-441.

CIRLOT, Juan-Eduardo. Dicionário de Símbolos. Tradução Rubens Eduardo Ferreira Frias. São Paulo: Editora Moraes, 1984.

COELHO, Nelly N. Dicionário crítico de escritoras brasileiras - 1711 a 2001. São Paulo: Escrituras Editora, 2002.

. Literatura Infantil - teoria, análise, didática. São Paulo: Ática, 1997.

. Tendências atuais da Literatura Feminina no Brasil. In: CAMARGO, Ana M. (org.). Feminino singular: a participação da mulher na literatura contemporânea. São Paulo/Rio Claro: Edições GRD/Arquivo Municipal de Rio Claro, 1989, p. 4-13.

- A Presença da 'nova mulher' na ficção brasileira atual. Revista Iberoamericana, [S.I.], v.1, n. 126, enero-marzo 1984.

COSTA, Iná Camargo. Panorama do Rio Vermelho - Ensaios sobre o teatro americano moderno. São Paulo: Nankin Editorial, 2001.

DALCASTAGNÈ, Regina. Sombras da cidade - o espaço na narrativa brasileira contemporânea. In: Estudos de literatura brasileira contemporânea, Brasília, nº 21, p.33-53, jan./jun. 2003.

A personagem feminina na narrativa brasileira dos anos 90. In: PIRES, Maria Isabel E. (org.). Formas e dilemas da representação da mulher na literatura contemporânea. Brasília: Editora da Universidade de Brasília, 2008, p. 99-106.

DAL FARRA, Maria Lúcia. O narrador ensimesmado (O foco narrativo em Vergílio Ferreira). São Paulo: Ática, 1978.

DEL PRIORE, Mary. Corpo a corpo com a mulher: pequena história das transformações do corpo feminino no Brasil. São Paulo: Editora SENAC São Paulo, 2000. (Série Ponto Futuro 2).

DEL PRIORE, Mary (org.). História das mulheres no Brasil. São Paulo: Edunesp/Contexto, 1997. 
D'INCAO, Maria Ângela. Mulher e família burguesa. In: DEL PRIORE, Mary (org.). História das mulheres no Brasil. São Paulo: Edunesp/Contexto, 1997, p. 223-240.

(org.). Amor e família no Brasil. São Paulo: Contexto, 1989.

D'ONOFRIO, Salvatore. Teoria do texto 2- teoria da lírica e do drama. São Paulo: Ática, 2000 .

DUHAMEL, Marie-Pierre. 66th Venice film festival: Ghosts in Venice. Mubi, [S.I.],09 sept. 2009. Disponível em: $<$ http://mubi.com/notebook/posts/993?from_theauteurs $=1>$ Acesso em: 12 nov. 2009.

ELIADE, Mircea. Tratado de história das religiões. Tradução Fernando Tomaz e Natália Nunes. 2. ed.São Paulo: Martins Fontes, 1998.

FALK, Signi L. The Southern Gentlewoman e The Degenerating Artist. Tennessee Williams. New Haven: College \& University Press, 1961. (Twayne's United States Authors Series)

FENTRESS, James. Preservação e Modernidade. In: MIRANDA, Danilo Santos de. (org.). Memória e cultura: a importância da memória na formação cultural humana. São Paulo: Edições SESC SP, 2007, p. 34-51.

FERREIRA, Débora R. S. Pilares narrativos: a construção do eu e da nação na prosa de oito romancistas brasileiras. Introdução: Susan C. Quinlan. Florianópolis: Ed. Mulheres, 2003.

FORTES, Leandro. Política interna. In: PINSKY, Jaime (org.) O Brasil no contexto: 19872007. $2^{a}$ ed. São Paulo: Contexto, 2007, p.63-71.

FREUD, Sigmund. Uma nota sobre o 'Bloco Mágico'. In: Obras Psicológicas Completas de Sigmund Freud. v. 19. Edição Standard Brasileira. Rio de Janeiro: Imago, 1987.

FRYE, Northrop. Fábulas de identidade- Estudos de Mitologia Poética. Trad. Sandra Vasconcelos. São Paulo: Nova Alexandria, 2000.

Cultrix, 1973.

Anatomia da crítica. Tradução Péricles Eugênio da Silva Ramos. São Paulo:

FUNCK, Susana B. Da questão da mulher à questão do gênero. In:

idéias sobre Mulher e Literatura. Florianópolis: UFSC, 1994, p.17-22. . (org.) Trocando

FURTADO, Joaci P. Barroco, Neobarroco, Pós-Moderno - Entrevista com João Adolfo Hansen. In: Cult- Revista Brasileira de Literatura, São Paulo, ano 1, n. 10, maio 1998.

GIDDENS, Antony. A transformação da intimidade: sexualidade, amor e erotismo nas sociedades modernas. Tradução Magda Lopes. São Paulo: Editora da UNESP, 1993.

GOETHE, Johann Wolfang von. Fausto. Tradução Jenny Klabin Segall. Belo Horizonte: Itatiaia, 1981. (Grandes Obras da Cultura Universal v.3)

GOMES, Renato C. A cidade, a literatura e os estudos culturais: do tema ao problema. Ipotesi: Revista de estudos literários. Juiz de Fora, v. 3, n. 2, p. 19-30, 1999. Disponível em: 
$<$ http://www.ufjf.br/revistaipotesi/files/2009/12/A-CIDADE-A-LITERATURA-E-OSESTUDOS1.pdf $>$. Acesso em: 08 maio 2006.

GOTLIB, Nádia Batella. A literatura feita por mulheres no Brasil. In: BRANDÃO, Izabel; MUZART, Zahidé L. Refazendo Nós: ensaios sobre mulher e literatura. Florianópolis: Ed. Mulheres; Santa Cruz do Sul: EDUNISC, 2003.

GRAZIANI, Françoise. Apolo, o Sol Mítico. In: BRUNEL, Pierre (org.). Dicionário de mitos literários. Tradução Carlos Sussekind et al. 4. ed. Rio de Janeiro: José Olympio Editora, 2005, p.66-71.

GRAZZINI, Giovanni. Le ore nude [critica]. Il Corriere della Sera, s/d. Disponível em: $<$ http://www.mymovies.it/dizionario/critica.asp?id=73083> Acesso em: 12. Nov. 2009.

GUÉRIOS, Prof. Rosário F. M. Nomes e sobrenomes - Tudo o que você gostaria de saber e não lhe contaram: Dicionário Etimológico. 4. ed. São Paulo: Ave-Maria Edições, 1994.

HAUSER, Arnold. Naturalismo e Impressionismo. In: História social da arte e da literatura. Tradução Álvaro Cabral. São Paulo: Martins Fontes, 1998, p. 727-955.

A era do cinema. In: História social da arte e da literatura. Tradução Álvaro Cabral. São Paulo: Martins Fontes, 1998, p.957-992.

HELIODORA, Barbara. O herói e seu antagonista. In: Falando de Shakespeare. São Paulo: Perspectiva, 2001, p. 93-114.

p.133-152.

. O fim. In: Falando de Shakespeare. São Paulo: Perspectiva, 2001,

HOBSBAWM, Eric. Era dos extremos - o breve século XX: 1914-1991. Tradução Marcos Santarrita; revisão técnica Maria Célia Paoli. São Paulo: Companhia das Letras, 1995.

HOLLANDA, Heloísa B. Feminismo em tempos pós-modernos. In: (org.). Tendências e impasses: o feminismo como crítica da cultura. Rio de Janeiro: Rocco, 1994, p.7-19.

HUTCHEON, Linda. A incredulidade a respeito das metanarrativas: articulando pósmodernismo e feminismos. Tradução Margareth Rago. In: Labrys - Estudos Feministas, n. 12, jul.- dez. 2002. Disponível em <http://e-groups.unb.br/ih/his/gefem/labrys1_2/linda1.html $>$ Acesso em: 25 jun. 2008.

JAMESON, Fredric. Pós-Modernidade e sociedade de consumo. Novos Estudos Cebrap, $\mathrm{n}^{\mathrm{o}}$ 12, p.16-26, jun. 1985.

JOSEF, Bella. Reflections on recent Brazilian fiction. Review of Latin American Literature and Arts, [S.I.], n. 48, p.46-47, spring 1994.

KEZICH, Tullio. Le ore nude [critica]. Il Corriere della Sera, s/d. Disponível em: < http://www.mymovies.it/dizionario/critica.asp?id=61457> Acesso em: 12 nov. 2009.

KLINGER, Diana. Escrita de si como performance. Revista Brasileira de Literatura Comparada, n. 12, 2008, p. 11-30. 
LAPLANCHE, Jean; PONTALIS, Jean Bertrand. Vocabulário da Psicanálise. Tradução Pedro Temen. 4. ed. São Paulo: Martins Fontes, 2001.

LEJEUNE, Philippe; NORONHA, Jovita M. G. (org.) O pacto autobiográfico- de Rousseau a Internet. Tradução Jovita M. G. Noronha, Maria Inês Coimbra Guedes. Belo Horizonte: Editora UFMG, 2008.

LEMINSKI, Paulo. Caprichos e relaxos. São Paulo: Círculo do livro, 1987.

LIPOVETSKY, Gilles. A terceira mulher: permanência e revolução do feminino. Tradução Maria Lucia Machado. São Paulo, Companhia das Letras, 2000.

LOBO, Luiza. Guia de escritoras da literatura brasileira. Rio de Janeiro: Eduerj/Faperj,2006.

MAGALHÃES JÚNIOR, R. O livro de Ouro da Poesia da França - Antologia de Poetas Franceses (Do século XV ao século XX). Tradução de Guilherme de Almeida. Rio de Janeiro: Ediouro, s/d.

MAGALDI, Sábato. Tennessee Williams evoca o passado. In: O texto no teatro. 2. ed. São Paulo: Perspectiva, 1999, p.352-356.

Nelson Rodrigues - A peça que a vida prega. In: Moderna Dramaturgia Brasileira. São Paulo: Perspectiva, 1998.

MARIVAUX, P. Arlequin poli par l'amour. In: Théatre Complet. Préface de Jacques Scherer. Paris: Aux Éditions Du Seuil, 1964, p. 57-66.

MATOS, Olgária. Masculino e Feminino. Revista USP, São Paulo, n. 2, p. 133-138, jun., jul. e ago. 1989. Disponível em: <http://www.usp.br/revistausp/02/19-Olgária.pdf> Acesso em: 16 maio 2009.

- Apresentação à edição brasileira. In: CANEVACCI, Massimo (org.). Dialética da família. São Paulo: Brasiliense, 1982, p.7-11.

MEIRELES, Cecília. Mar absoluto e outros poemas: retrato natural. Rio de Janeiro: Nova Froenteira, 1983.

. Flor de poemas. Rio de Janeiro: Nova Fronteira, 1972.

MENESES, Ulpiano Bezerra de. Os paradoxos da memória. In: MIRANDA, Danilo Santos de. (org.). Memória e cultura: a importância da memória na formação cultural humana. São Paulo: Edições SESC SP, 2007, p. 13-33.

MERTEN, Luiz C. Esses italianos (2). Blog. MERTEN, Luiz C. Uma geléia geral a partir do cinema. Disponível em: < http://blogs.estadao.com.br/luiz-carlos-merten/esses-italianos-2/> Acesso em: 09 nov. 2009.

MIRANDA, Danilo Santos de. (org.). Memória e cultura- a importância da memória na formação cultural humana. São Paulo: Edições SESC SP, 2007.

MIRANDA, Wander Mello. Corpos escritos- Graciliano Ramos e Silviano Santiago. São Paulo: EdUSP, 1992. 
MORAVIA, Alberto. Encontro na praia. In: O autómato. Tradução Manuel Martins de Sá. [S.I]: Publicações Europa-América, 1972, p.7-11. (Livros de Bolso Europa-América, 40)

MORIN, Edgar. As estrelas de cinema. Lisboa: Livros Horizonte, 1980. (Col. Horizonte de Cinema 5)

NAPOLITANO, Marcos. Cultura brasileira: utopia e massificação (1950-1980). 3. ed. São Paulo: Contexto, 2008. (Repensando a História)

2a. ed. São Paulo: Contexto, 2007, p.139-149.

NOVAIS, Fernando A.; MELLO, João M. Cardoso de. Capitalismo tardio e sociabilidade moderna. In: SCHWARCZ, Lilia M. (org.) História da Vida Privada no Brasil: contrastes da intimidade contemporânea. V.4. São Paulo: Companhia das Letras, 1998, p. 559-658.

NUNES, Luiz Arthur. Apresentação. In: RODRIGUES, Nelson. Teatro completo- Peças psicológicas, v.1, 2.ed. São Paulo: Nova Fronteira, 2004, p.13-25.

OLIVEIRA, Maria Clara C.; LAGE, Verônica Lucy C. (orgs.). Literatura, crítica, cultura I. Juiz de Fora: Editora UFJF, 2008.

O’NEILL, E. Longa jornada noite adentro: drama em 4 atos. Tradução Helena Pessoa. São Paulo: Peixoto Neto, 2004. (Os grandes dramaturgos)

ORTIZ, Renato. A moderna tradição brasileira. 5. ed. São Paulo: Brasiliense, 1999.

PAES, José Paulo. As dimensões do fantástico. In: Gregos e Baianos. São Paulo: Brasiliense, 1985, p.184-192.

(org.). Os buracos da máscara- Antologia de contos fantásticos. Seleção, tradução e introdução: José Paulo Paes. São Paulo: Brasiliense, 1985.

PAVIS, Patrice. Dicionário de Teatro. São Paulo: Perspectiva, 1999.

PEDRO, Joana. Mulheres. In: PINSKY, Jaime (org.) O Brasil no contexto: 1987-2007. 2a. ed. São Paulo: Contexto, 2007, p.169-181.

PELLEGRINI, Tânia. Despropósitos - estudos de ficção brasileira contemporânea. São Paulo: Annablume; FAPESP, 2008.

p. 137-155, dez. 2007.

Realismo: postura e método. Letras de Hoje. Porto Alegre, v. 42, n.4,

A ficção brasileira hoje: os caminhos da cidade. Revista de Critica Literaria Latinoamericana, Lima-Hanover, Año XXVII, no 53, pp. 135-152, 1er. semestre del 2001.

A imagem e a letra - aspectos da ficção brasileira contemporânea.

Campinas: Mercado de Letras/ São Paulo: FAPESP, 1999. 
PERROT, Michelle (org.). História da vida privada 4- da Revolução Francesa à Primeira Guerra. Tradução Denise Bottmann, Bernardo Joffily. São Paulo: Companhia das Letras, 2009. (Companhia de Bolso)

. Minha história das mulheres. São Paulo: Contexto, 2007.

- Os silêncios do corpo da mulher. In: MATOS, Maria Izilda S.; SOIIHET, Rachel. O corpo feminino em debate. São Paulo: Editora da UNESP, 2003, p. 1327.

. Mulheres públicas. São Paulo: Editora da UNESP, 1998.

PILAGALLO, Oscar. O Brasil em sobressalto: 80 anos de historia contados pela Folha. São Paulo: Publifolha, 2002.

PINTO, Céli Regina Jardim. Uma história do feminismo no Brasil. São Paulo: Editora Fundação Perseu Abramo, 2003.

PIRES, Maria Isabel E. (org.). Formas e dilemas da representação da mulher na literatura contemporânea. Brasília: Editora da Universidade de Brasília, 2008.

POPPI, Roberto; PECORARI, Mario. Dizionario Del Cinema Italiano I Film vol.3 - Dal 1960 al 1969. Collaborazione di Enrico Lancia. Roma: Gremese Editore, 1992.

PORTER, Roy. História do corpo. In: BURKE, Peter (org.). A escrita da história: novas perspectivas. Tradução Magda Lopes. São Paulo: Editora UNESP, 1992, p. 291-326.

PROST, Antoine; VINCENT, Gérard. História da vida privada 5- da Primeira Guerra a nossos dias. Tradução Denise Bottmann; Posfácio Dorothée de Bruchard. São Paulo: Companhia das Letras, 2009. (Companhia de Bolso)

RAGO, Margareth. Trabalho feminino e sexualidade. In: DEL PRIORE, Mary (org.). História das mulheres no Brasil. São Paulo: Edunesp/Contexto, 1997, p. 578-606.

. Os feminismos no Brasil: dos “anos de chumbo" à era global. Labrys- estudos

feministas, n.3, jan.-jul. 2003. Disponível em: $<$ http://vsites.unb.br/ih/his/gefem/labrys3/web/bras/marga1.htm> Acesso em: 21 dez. 2009.

RAMALHO, Christina (org.). Literatura e feminismo: propostas teóricas e reflexões críticas. Rio de Janeiro: Elo, 1999.

REIS, Livia F.; VIANNA, Lúcia H.; PORTO, Maria B. (org.). VII Seminário Nacional Mulher e Literatura. Niterói: Sette Letras/EdUFF, 1999. 2v.

RODRIGUES, Nelson F.Vestido de Noiva: tragédia em três atos. In: Teatro completo- Peças psicológicas, v.1, 2.ed. Rio de Janeiro: Nova Fronteira, 2004.

RONÁI, Paulo. Curso Básico de Latim Gradus Primus. V.1. 10. ed. São Paulo: Cultrix, 1996.

ROONEY, Ellen (org.). The Cambridge Companion to Feminist Literary Theory. Cambridge: Cambridge University Press, 2006. 
ROSENFELD, Anatol. Reflexões sobre o romance moderno. In: Texto/Contexto I. São Paulo: Perspectiva, 1996, p. 75-97.

. A teoria dos gêneros. In: O Teatro Épico. São Paulo: Perspectiva, 1986.

Perspectiva, 1986, p.15-19.

- Gêneros e traços estilísticos. In: O Teatro Épico. São Paulo:

. A essência do teatro. In: Prismas do teatro. São Paulo:

Perspectiva/EDUSP; Campinas: Editora da UNICAMP, 1993, p.21-26.

SAFFIOTI, Heleieth I. B. A mulher na sociedade classes: mito e realidade. Petrópolis: Vozes, 1979.

SAMARA, Eni de Mesquita. A família brasileira. São Paulo: Brasiliense, 2004. (Coleção Tudo é História 71.)

SANT'ANNA, Denise Bernuzzi de. A insustentável visibilidade do corpo. In: Labrys estudos feministas, no 4, ago. - dez. 2003. Disponível em: $<$ http://vsites.unb.br/ih/his/gefem/labrys4/textos/anahi1.htm> Acesso em: 21 dez. 2009.

SANTIAGO, Silviano. O narrador pós-moderno. In: Nas malhas da letra. Rio de Janeiro: Rocco, 2002, p.44-60.

SARLO, Beatriz. Tempo passado: cultura da memória e guinada subjetiva. Tradução Rosa Freire D’Aguiar. São Paulo: Companhia das Letras/ Belo Horizonte: UFMG, 2007.

Edusp, 1997, p.171-196.

Mulheres, História e Ideologia. In: Paisagens imaginárias. São Paulo,

SCHNEIDER, Liane. A representação do feminino como política de resistência. In: PETERSON, Michel; NEIS, Ignácio Antonio (org.). As armas do texto: a literatura e a resistência da literatura. Porto Alegre: Ed. Sagra Luzzato, 2000, p.119-139. (PPG- UFRGS).

SCHWARZ, Roberto. Que horas são? 2.ed. São Paulo: Companhia das Letras, 2006.

. Sequências Brasileiras. São Paulo: Companhia das Letras, 1999.

2001, p. 59-83. (Col. Leitura)

As ideias fora de lugar. In: Cultura e política. São Paulo: Paz e Terra,

SCOTT, Joan. História das mulheres. In: BURKE, Peter (org.). A escrita da história: novas perspectivas. Tradução Magda Lopes. São Paulo: Editora UNESP, 1992, p. 63-95.

SELIGMANN-SILVA, Márcio. A língua como leito da memória cultural e meio de diálogo entre as culturas. In: MIRANDA, Danilo Santos de. (org.). Memória e cultura: a importância da memória na formação cultural humana. São Paulo: Edições SESC SP, 2007, p.68-79.

Reflexões sobre a memória, a história e o esquecimento. In:

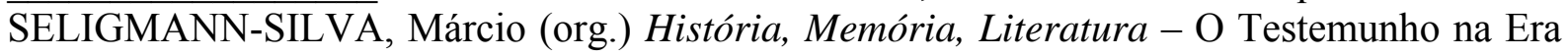
das Catástrofes. Campinas: Editora UNICAMP, 2003, p. 59-88. 
SELIGMANN-SILVA, Márcio. O Testemunho: entre ficção e o 'real'. In: SELIGMANNSILVA, Márcio (org.) História, Memória, Literatura - O Testemunho na Era das Catástrofes. Campinas: Editora UNICAMP, 2003, p. 371-386.

Catástrofes. Campinas: Editora UNICAMP, 2003. (org.) História, Memória, Literatura - O Testemunho na Era das

SEVCENKO, Nicolau. A corrida para o século XXI: no loop da montanha-russa. São Paulo: Companhia das Letras, 2001 (Col. Virando Séculos v.7).

SHAKESPEARE, William. Hamlet. Tradução Barbara Heliodora. Rio de Janeiro: Lacerda, 2004.

2004.

. Macbeth. Tradução Barbara Heliodora. Rio de Janeiro: Lacerda,

. The tragedy of King Lear. Russell Fraser (Ed.) New York: Signet, 1963. (The Signet Classic Shakespeare v. 160)

The tragedy of Macbeth. Sylvan Barnet (Ed.) New York: Signet, 1963. (The Signet Classic Shakespeare v. 161)

. The tragedy of Hamlet, prince of Denmark. Edward Hubler (Ed.) New York: Signet, 1963. (The Signet Classic Shakespeare v. 169)

SHOWALTER, Elaine. A literature of their own- from Charlotte Brontë to Doris Lessing. Princeton: Princeton UP, 1977.

Toward a Feminist Poetics. In: (org.) The New Feminist

Criticism - essays on women, literature and theory. New York: Pantheon Books, 1985, p.125144.

. (org.) The New Feminist Criticism - essays on women, literature and theory. New York: Pantheon Books, 1985.

A crítica feminista no território selvagem. In: HOLLANDA, Heloísa B. (org.). Tendências e impasses: o feminismo como crítica da cultura. Rio de Janeiro: Rocco, 1994, p.23-57.

SIGANOS, André. Bestiário mítico. In: BRUNEL, Pierre (org.). Dicionário de mitos literários. Tradução Carlos Sussekind et al. 4. ed. Rio de Janeiro: José Olympio, 2005, p. 117137.

SKIDOMORE, Thomas E. Brasil: De Castelo a Tancredo. Tradução Mario Salviano Silva. Rio de Janeiro: Paz e Terra, 1988.

SUSSEKIND, Flora; DIAS, Tânia; AZEVEDO, Carlito (orgs.). Vozes Femininas: gênero, mediações e práticas da escrita. Rio de Janeiro: 7 Letras/ Fund. Casa Rui Barbosa, 2003.

SZONDI, Peter. Teoria do drama moderno (1880-1950). Tradução Luiz Sérgio Repa. São Paulo: Cosac e Naify Edições, 2001. 
SWAIN, Tânia N. Velha? Eu? Autorretrato de uma feminista. In: Labrys - estudos feministas, n० 4, ago. $\quad-\quad$ dez. $2003 . \quad$ Disponível em: $<$ http://vsites.unb.br/ih/his/gefem/labrys4/textos/anahi1.htm> Acesso em: 21 dez. 2009.

TACCA, Oscar. As vozes do romance. Coimbra: Livraria Almedina, 1983.

TEIXEIRA, Níncia C. R. B. Letras femininas: a escrita do 'eu' no universo de Luci Collin. Revista Brasileira de Literatura Comparada, n. 12, 2008, p.329-364.

TODOROV, Tzvetan. Introdução à literatura fantástica. 2. ed. São Paulo: Perspectiva, 2003.

TORRANO, Jaa. O mundo como função das Musas. In: HESÍODO. Teogonia: a origem dos deuses. Estudo e tradução Jaa Torrano.7. ed. São Paulo: Iluminuras, 2007, p.13-97.

TULARD, Jean. Dicionário de cinema: Os diretores. Tradução Moacyr Gomes Jr. Atualização de Goida. Porto Alegre: L\&PM, 1996.

VASCONCELOS, Sandra G. T. Dez lições sobre o romance inglês do século XVIII. São Paulo: Boitempo Editorial, 2002.

VENDRAMINI, José Eduardo. A Commedia dell'arte e sua reoperacionalização. Trans/Form/Ação. Marília, v. 24, n.1, 2001. Disponível em : $<$ http://www.scielo.br/scielo.php?script=sci_arttext\&pid=S0101-

$31732001000100004 \& \operatorname{lng}=$ en\&nrm=iso $>$ Acesso em: 28 jan. 2009.

VENTURI, Gustavo; RECAMÁN, Marisol; OLIVEIRA, Suely (orgs.). A mulher brasileira nos espaços público e privado. São Paulo: Ed. Fund. Perseu Abramo/ Friedrich Ebert Steftung, 2004.

VIANNA, Lúcia H. Cenas de amor e morte na ficção brasileira - O jogo dramático da relação homem/mulher na literatura. Niterói: EdUFF, 1999.

. Poética feminista, poética da memória. In: Labrys - estudos feministas, n. 4, ago - dez. 2003. Disponível em: < http://www.unb.br/ih/his/gefem/labrys4/textos/lucia1.htm> Acesso em: 25 jun. 2008.

VILLAÇA, Nízia. Paradoxos do pós-moderno: sujeito \& ficção. Rio de Janeiro: Editora da UFRJ, 1996.

VINCENT, Gérard. Segredos de Família. In: PROST, Antoine; VINCENT, Gérard (orgs.). História da vida privada 5 - da Primeira Guerra a nossos dias. Tradução Denise Bottmann; Posfácio Dorothée de Bruchard. São Paulo: Companhia das Letras, 2009, p. 223-281. (Companhia de Bolso)

WILDE, Oscar. O retrato de Dorian Gray. Tradução Oscar Mendes. São Paulo: Círculo do Livro, s/d.

. Ensayos: El critico artista- parte II. In: . Obras completas. Tradução Julio Gomez de la Serna. Madrid: Aguilar, 1958, p. 938-966.

WILLIAMS, Tennessee. Sweet bird of youth/ Rose Tatoo/ Night of Iguana. New York: Signet, 1992. 
WILLIAMS, Tennessee. The Glass Menagerie. New York: New Directions Publishing, 1970.

XAVIER, Elódia. Que corpo é esse? O corpo no imaginário feminino. Florianópolis: Editora Mulheres, 2007.

. Declínio do Patriarcado - A família no imaginário feminino. Rio de Janeiro: Rosa dos Ventos/ Record, 1998.

. Reflexões sobre a narrativa de autoria feminina. In: XAVIER, Elódia (org.) Tudo no feminino - a mulher e a narrativa brasileira contemporânea. Rio de Janeiro: Francisco Alves, 1991, p. 9-16.

(org.). Tudo no feminino - a mulher e a narrativa brasileira contemporânea. Rio de Janeiro: Francisco Alves Editora, 1991.

ZINANI, Cecil J. A. Literatura e Gênero: a construção da identidade feminina. Caxias do Sul: Educs, 2006. 